UNIVERSIDADE DE SÃO PAULO

FACULDADE DE FILOSOFIA, LETRAS E CIÊNCIAS HUMANAS

DEPARTAMENTO DE HISTÓRIA

PROGRAMA DE PÓS-GRADUAÇÃO EM HISTÓRIA SOCIAL

Roberto Nicolas Puzzo Ferreira Saba

As Vozes da Nação: a atividade peticionária e a política do início do Segundo Reinado 
UNIVERSIDADE DE SÃO PAULO

FACULDADE DE FILOSOFIA, LETRAS E CIÊNCIAS HUMANAS

DEPARTAMENTO DE HISTÓRIA

PROGRAMA DE PÓS-GRADUAÇÃO EM HISTÓRIA SOCIAL

\section{As Vozes da Nação: a atividade peticionária e a política do início do Segundo Reinado}

\section{Roberto Nicolas Puzzo Ferreira Saba}

Dissertação apresentada ao Programa de Pós-Graduação em História Social do Departamento de História da Faculdade de Filosofia, Letras e Ciências Humanas da Universidade de São Paulo para a obtenção do título de Mestre em História.

Orientadora: Profa. Dra. Miriam Dolhnikoff 
Para Livia. 
"A man who has nothing which he is willing to fight for, nothing which he cares more about than he does about his personal safety, is a miserable creature who has no chance of being free, unless made and kept so by the exertions of better men than

John Stuart Mill, 1867. 


\section{RESUMO}

Ao lado da liberdade de expressão, a Constituição de 1824 garantiu o direito da sociedade se fazer ouvir pelas autoridades: o Artigo 179, parágrafo 30 estabelece que “todo o cidadão poderá apresentar por escrito ao Poder Legislativo e ao Executivo reclamações, queixas, ou petições." A presente dissertação tem por objetivo compreender como este direito constitucional foi utilizado pelos cidadãos brasileiros durante o período em que a ordem monárquica constitucional se consolidava no Brasil. Durante os primeiros anos do Segundo Reinado, diversos grupos - comerciantes, médicos, advogados, manufatureiros, autoridades locais, padres, proprietários de terra, votantes, eleitores etc. - estabeleceram uma relação direta com a elite política que moldava as instituições do Império. A análise das petições que chegaram à Câmara dos Deputados na década de 1840 e do debate parlamentar que nela se desenvolveu indica que importantes mudanças políticas do período - como a reforma eleitoral, a aprovação do Código Comercial, a reforma judiciária - foram influenciadas por setores da sociedade brasileira que se organizaram para exercer o direito de petição. Por intermédio da atividade peticionária, governantes e governados se integraram em um diálogo que permeou a resolução de alguns dos mais relevantes assuntos concernentes à realidade brasileira. Este diálogo fez do ideal do regime representativo algo tangível para diversos setores que compunham o pacto político nacional.

Palavras-chave: Brasil Imperial; Segundo Reinado; Petições; Regime Representativo; Reforma Eleitoral; Código Comercial; Reforma Judiciária. 


\begin{abstract}
Together with the freedom of thought and speech, the Constitution of 1824 provided Brazilian society with the right to be heard by authorities: Article 179, Paragraph 30 states that "all citizens will be able to present to the Legislative or the Executive Power written grievances, complaints, or petitions." This dissertation attempts to explore how this constitutional right was used by Brazilian citizens during the time that monarchical order was being consolidated. During the reign of D. Pedro $2^{\text {nd }}$, many groups, including businessmen, manufacturers, doctors, lawyers, local authorities, priests, landowners, voters, electors, and others, established a direct relation with the political elite responsible for molding the new institutions. The analysis of the petitions sent to the Chamber of Deputies by the 1840's and the parliamentary debate ensued provide an indication that important political changes of that period (i.e., electoral reform, approval of the Commercial Code, judicial reform) were influenced by the participation of certain sections of Brazilian society that were able to organize themselves and successfully use their right of petition. Mediated by such petitionary activity, governors and governed took part in a dialogue that led to the resolution of some of the most important issues concerning Brazilian reality. That dialogue made the ideal of representative government tangible to many groups that formed the prevailing national political landscape.
\end{abstract}

Keywords: Empire of Brazil; Second Reign; Petitions; Representative Government; Electoral Reform; Commercial Code; Judicial Reform. 


\section{AGRADECIMENTOS}

Sem a valiosa colaboração de alguns professores eu jamais teria conseguido empreender o trabalho que agora apresento. Por isso, gostaria de expressar aqui minha profunda gratidão para com eles. Em primeiro lugar, gostaria de agradecer à Dra. Miriam Dolhnikoff, pesquisadora cujas idéias formaram a base de minha formação como historiador e orientadora atenciosa. Gostaria também de agradecer àqueles que aceitaram participar das bancas que avaliaram o presente trabalho e, com suas análises, enriqueceram meu aprendizado: Dr. Cícero Romão Araújo, Dra. Lúcia Maria B. P. das Neves e Dra. Monica Duarte Dantas. Por fim, expresso meu sincero agradecimento aos professores cujas aulas e conversas foram essenciais para o aprimoramento das idéias contidas na presente dissertação: Dra. Andréa Slemian, Dra. Angela Alonso e Dr. Elias Thomé Saliba.

Também algumas instituições foram essenciais para que eu conseguisse chegar até aqui. Agradeço ao auxílio financeiro concedido pela Fundação de Amparo à Pesquisa do Estado de São Paulo, que permitiu que eu pudesse me dedicar integralmente à minha pesquisa de mestrado. Agradeço também aos profissionais do Centro de Documentação e Informação do Arquivo da Câmara dos Deputados, que me acolheram e trabalharam comigo para que eu pudesse coletar a documentação que fundamentou minha dissertação.

Esta dissertação não teve, no entanto, o auxílio apenas de professores e instituições. Gostaria agora de agradecer àqueles que sempre estiveram ao meu lado e me incentivaram nesta empreitada. Meu pai Paulo, pelo exemplo de trabalho e responsabilidade, e minha mãe Dirce, pela dedicação incondicional, estão e sempre estarão em tudo o que faço, agradecer-lhes pelo que fizeram por mim seria muito pouco. Aos meus irmãos desde sempre, Tato e Fabiana, e aos meus novos irmãos, Carla e Ralph, agradeço por terem feito parte do meu crescimento e por terem sempre acreditado em mim. Aos meus sobrinhos Bubu, Victoria, Gabriela e àquela que ainda está por nascer, eu agradeço pela alegria que me proporcionam. Agradeço ao meu padrinho, Roberto, e à minha madrinha, tia Maria, pelo carinho que sempre tiveram por mim. Agradeço também à minha tia Naná que, com seus causos e poemas, foi uma das grandes responsáveis por eu ter optado pelo estudo das Humanidades. À minha tia Amélia agradeço por ter me hospedado em Maringá e por ter me trazido à lembrança minhas origens. Agradeço ainda à Rose pela paciência e por todo o auxílio. À amiga Yannick agradeço pelas enriquecedoras aulas de "langue et civilisation françaises". Ao 
amigo Rogério agradeço por ter despertado em mim o interesse pelo estudo da sociedade brasileira e por ter me ensinado qual o verdadeiro papel de um intelectual. Por fim, agradeço àquela que durante os últimos quatro anos esteve sempre ao meu lado, nos momentos bons e nos ruins, àquela que quero como companheira por toda a vida: Lívia, obrigado por dar sentido às coisas que faço. 


\section{ÍNDICE}

INTRODUCÃ̃O 2

CAPÍTULO 1. OS NOTÁVEIS E A NAČ̃̃O: O DIREITO DE PETIC̃̃̃O SOB O REGIME REPRESENTATIVO

CAPÍTULO 2. DE SÚDITOS A REPRESENTADOS: A ATIVIDADE PETICIONÁRIA NO ANTIGO REGIME PORTUGUÊS E NA MONARQUIA CONSTITUCIONAL BRASILEIRA

CAPÍTULO 3. AS "ELEICÕES DO CACETE" E A QUESTÃO DA LEGITIMIDADE DA REPRESENTAĊ̃̃O POLÍTICA NO IMPÉRIO 64

CAPÍTULO 4. AS PRACAS COMERCIAIS E A INSTAURACÃO DO CÓDIGO COMERCIAL BRASILEIRO

CAPÍTULO 5. A ELITE POLÍTICA LUZIA E A LUTA CONTRA AS "LEIS REACIONÁRIAS" 


\section{INTRODUÇÃO}

A história política do Brasil oitocentista tem passado por uma grande renovação nos últimos anos. Novas perspectivas têm sido adotadas para o estudo de objetos considerados clássicos. As instituições imperiais estão sendo revisitadas a partir de teorias que as inserem no contexto mais amplo da construção dos Estados Nacionais da era contemporânea. Em meio à nova safra historiográfica, um grupo de pesquisadores da Universidade de São Paulo tomou como objeto de sua atenção o parlamento do Brasil imperial. Os debates que se desenrolaram durante o período monárquico dentro da Câmara dos Deputados foram analisados a partir da perspectiva da representação política, base de alguns sistemas de governo que se constituíram na virada do século XVIII para o XIX em determinados países do Ocidente. ${ }^{1}$

Os resultados das novas pesquisas apontam para a existência de um sistema político complexo no Império; sistema este que transcendia a vontade de um monarca ou de uma elite política homogênea. A existência de eleições periódicas e disputadas, de debates parlamentares acalorados e de projetos dissonantes em meio à elite nacional; a organização de partidos políticos, de grupos de pressão e de uma opinião pública; as rupturas e os alinhamentos entre posições políticas dentro e fora da arena parlamentar; o combate aos desvios da norma (fraude, corrupção etc.) e o apego à legalidade e às instituições; a circulação das idéias políticas por meio de uma imprensa militante; e outros muitos fatores demonstram que as disputas políticas no Brasil oitocentista iam muito além de uma simples fachada para um regime de cunho antiliberal. A linha de estudos acima referida mostra que no Império brasileiro havia um regime que funcionava, em grande medida, de acordo com os preceitos da representação política elaborados na virada do século XVIII para o XIX em países como Inglaterra, Estados Unidos e França.

\footnotetext{
${ }^{1}$ Dentre os resultados parciais da pesquisa, destacam-se as seguintes contribuições: Miriam Dolhnikoff. "Império e governo representativo: uma releitura". Cadernos do CRH (UFBA). Volume 21, 2008. Disponível no endereço eletrônico: http://www.cadernocrh.ufba.br/viewarticle.php?id=543. Acessado em 15 de novembro de 2008; Miriam Dolhnikoff. "Representação na monarquia brasileira". Almanack Brasiliense (IEB/USP). Número 9, maio de 2009. Disponível no endereço eletrônico: http://www.almanack.usp.br/neste numero/n01/index.asp?edicao=9\&tipo=forum\&conteudo=290.

Acessado em 05 de maio de 2009; Hernan Enrique L. Sáez. "Nas asas de Dédalo. Um estudo sobre o meio circulante no Brasil entre os anos de 1840 e 1853". Dissertação de mestrado defendida no ano de 2008 na Universidade de São Paulo; Vítor Marcos Gregório. "Uma Face de Jano: a navegação do rio Amazonas e a formação do Estado brasileiro (1838-1867)". Dissertação de mestrado defendida no ano de 2008 na Universidade de São Paulo; Tassia T. Nunes. "Liberdade de imprensa no Império brasileiro. Os debates parlamentares (1820-1840)". Dissertação de mestrado defendida no ano de 2010 na Universidade de São Paulo.
} 
Inserida nos estudos acerca do funcionamento do regime representativo no Império, minha pesquisa de iniciação científica (2007) focou o embate entre abolicionistas, anti-abolicionistas e escravistas dentro da Câmara dos Deputados - mais especificamente, o debate em torno da aprovação daquela que viria a ser conhecida como Lei dos Sexagenários. ${ }^{2}$ Durante a realização da pesquisa foi possível notar que petições de associações de agricultores escravocratas e de sociedades abolicionistas adquiriram relevante importância dentro do debate parlamentar. Sua apresentação diante dos deputados causava grande comoção: era como se as vozes da nação governada diretamente interviessem sobre a atividade do legislador. Estas petições eram levadas a sério pelos representantes da nação que as utilizavam como armas em prol de suas causas.

A primeira hipótese que levantei sobre a importância das petições no Império foi que elas estavam intrinsecamente ligadas ao debate acerca da "questão servil" e à ascensão política de um movimento popular, o abolicionismo. Contudo, tal hipótese foi logo refutada. Observando os Anais da Câmara dos Deputados do início do Segundo Reinado, pude constatar que uma intensa atividade peticionária se dirigia ao parlamento do Império acerca de questões políticas nacionais muito antes da formação do movimento abolicionista: somente para o ano de 1850, por exemplo, foi possível quantificar a partir dos Anais 255 petições recebidas pela mesa da Câmara. Assim, elaborei minha pesquisa de mestrado com a finalidade de compreender a atividade peticionária do Segundo Reinado como um todo. Quando, no início de 2008, empreendi uma pesquisa no Centro de Documentação e Informação do Arquivo da Câmara dos Deputados, a surpresa foi ainda maior: lá pude consultar 1.186 petições $^{3}$ (contendo cada uma cerca 6 ou 8 páginas redigidas à mão) referentes somente às décadas de $1840 \mathrm{e}$ 1850.

Dada a vasta documentação encontrada para as primeiras décadas do Segundo Reinado, as dimensões traçadas pelo projeto original tiveram de ser reduzidas. Deste modo, apenas a década de 1840 e, dentro dela, algumas questões políticas mais destacadas, se tornaram o objeto de análise da dissertação. Não obstante a redução do escopo temporal, a complexidade do trabalho a ser empreendido se manteve, já que os

\footnotetext{
${ }^{2}$ Roberto Nicolas P. F. Saba. "A Questão Servil no Debate Parlamentar (1883-1884)". Relatório de pesquisa FAPESP (1). Maio de 2007; Roberto Nicolas P. F. Saba. "A Questão Servil no Debate Parlamentar (1885)". Relatório de pesquisa FAPESP (2). Novembro de 2007.

${ }^{3} \mathrm{O}$ termo petição será adotado de forma geral neste trabalho por ser o mais comum entre os diversos termos que se referiam à documentação aqui analisada (representação, requerimento, súplica etc.).
} 
anos que se seguiram à maioridade de $\mathrm{D}$. Pedro II formaram um importante momento de aprendizado político para os brasileiros: depois de quase duas décadas de intensa agitação, de guerras civis e profundas reformas, o país fixava as bases da estabilidade de seu regime. A monarquia constitucional, estabelecida a partir do pensamento político ocidental que sucedeu às revoluções de 1776 na América do Norte e de 1789 na França, finalmente se assentava: a década de 1840 assistiu à estruturação do longo e estável reinado de D. Pedro II. Em torno do jovem imperador a elite política do Império enfim aprendia como as disputas entre projetos rivais podiam ser resolvidas dentro das instituições legitimamente reconhecidas. Neste contexto, a atividade peticionária adquiriu grande importância.

A historiografia já demonstrou, por diversas perspectivas diferentes, como os primeiros anos do Segundo Reinado foram vitais para a estabilização do regime monárquico constitucional no Brasil. O historiador Sérgio Buarque de Holanda, por exemplo, deixa bem claro que o projeto de unificação nacional brasileira não se completou nem com a Independência e nem durante o Primeiro Reinado, mas na década de 1840: "pois não é durante a Regência e, ainda, nos oito ou nove anos que se seguem à Maioridade que forças centrífugas latentes, capazes, sem freio, de levar à desintegração do Império bragantino na América, se fazem mais ruidosamente manifestas? Se fosse possível marcar mais nitidamente o remate do processo tendente à unidade nacional, depois da dispersão, caberia talvez situá-lo por volta de 1848, ano em que os nossos liberais quebram os remos."4 O fim da Revolução Praieira em Pernambuco, segundo Sérgio Buarque, foi o marco da unificação nacional e da estabilização política do Império. Desagregava-se, enfim, a partir da legitimação do poder central sobre as elites regionais, a herança colonial de poderes locais fortemente propensos à luta por autonomia política. Ao esmagamento das forças centrífugas se sucedeu um tempo de paz no Brasil.

Em uma linha de pensamento complementar àquela seguida por Sérgio Buarque de Holanda se coloca a historiadora Maria Odila L. S. Dias: "a vinda da Corte com o enraizamento do Estado português no Centro-Sul daria início à transformação da colônia em metrópole interiorizada. Seria esta a única solução aceitável para as classes dominantes em meio à insegurança que lhes inspiravam as contradições da sociedade

\footnotetext{
${ }^{4}$ Sérgio Buarque de Holanda. "A herança colonial - sua desagregação" In: Idem (org.). História Geral da Civilização Brasileira. Tomo II: O Brasil Monárquico. Volume 3: O processo de emancipação. Rio de Janeiro: Bertrand Brasil, 2003. p. 23.
} 
colonial, agravadas pelas agitações do constitucionalismo português e pela fermentação mais generalizada do mundo inteiro na época, que a Santa Aliança e a ideologia da contra-revolução na Europa não chegavam a dominar. Pode-se dizer que este processo, que parte do Rio e do Centro-Sul, somente se consolidaria com a centralização política realizada por homens como Caxias, Bernardo de Vasconcelos, Visconde do Uruguai, consumando-se politicamente com o Marquês de Paraná e o Ministério da Conciliação." A interiorização de um governo fortemente centralizado que impedia as manifestações desagregadoras tanto das classes ínfimas quanto das elites locais só se firmou efetivamente no Império, segundo Dias, quando na década de 1840 um grupo de estadistas preparados para o governo nacional chegaram ao poder de Estado.

O historiador José Murilo de Carvalho foi responsável pela formulação de uma explicação inovadora sobre a estabilização do Estado monárquico no Brasil. Segundo ele, o agente responsável pela regularização da vida política do Império foi uma elite política de formação homogênea, cuja educação e circulação pelos postos da burocracia estatal diferenciavam-na do resto da sociedade brasileira. A década de 1840 foi um período essencial para o seu estabelecimento no poder de Estado. Havia uma clara diferença, explica Carvalho, entre os governantes brasileiros da década de 1840 e os quadros políticos anteriores, "um corte radical provocado pela Independência, o qual resultou na formação de duas gerações distintas de políticos, uma formada em Portugal (Coimbra), a outra formada no Brasil (São Paulo e Olinda/Recife)." 6 A primeira geração dominou durante as décadas de 1820 e 1830, enquanto a segunda tomou o governo nacional a partir da década de 1840, uma década de transição das elites que dominavam politicamente o país. Os anos que sucederam a elevação ao trono de D. Pedro II, ele mesmo um rei nascido no país, foram essenciais para que uma elite política brasileira - formada no Brasil - tomasse definitivamente o poder das mãos dos coimbrãos e terminasse a obra de construção da ordem político-institucional do Império. Esta elite foi bem-sucedida, segundo o historiador, pois conseguiu se descolar dos interesses imediatos da retrógrada sociedade nacional e governá-la a partir de uma concepção modernizante.

Para o historiador Ilmar R. de Mattos, na década de 1840 foram construídos os pilares da hegemonia política de um grupo específico de dirigentes no Império

\footnotetext{
5 Maria Odila L. S. Dias. “A interiorização da metrópole” In: Carlos Guilherme Mota (org.). 1822: Dimensões. São Paulo: Perspectiva, 1986. p. 171.

6 José Murilo de Carvalho. A Construção da Ordem: a elite política imperial/Teatro das Sombras: a política imperial. Rio de Janeiro: Civilização Brasileira, 2007. p. 80.
} 
brasileiro. Compreendendo desde a alta burocracia do Estado até os proprietários de terras, passando por jornalistas, médicos, professores, literatos e outros mais, o grupo saquarema - originário da região cafeeira da província fluminense - impôs seu projeto de nação a partir de vitórias políticas e militares sobre um grupo concorrente, mais especificamente, sobre as elites políticas liberais de Minas Gerais, São Paulo e Pernambuco. A partir do esmagamento das últimas revoltas em 1842 e 1848 - explica o autor de O Tempo Saquarema - "o triunfo conservador reduziria as pretensões e ilusões liberais quase a pó. O triunfo conservador iria impor a unificação das diversas denominações liberais, a partir da referência a uma derrota, estigmatizando-os pelos tempos afora. Derrotados, os luzias deveriam sofrer os rigores da redução de sua

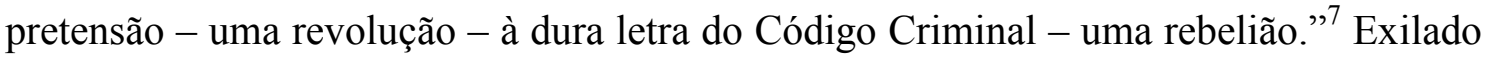
do poder estatal, o projeto político liberal, que tantos transtornos tinha trazido à ordem política imperial durante as décadas de 1820 e 1830, sucumbiu na década de 1840 sob a dominação centralizadora da elite saquarema. Esta, por sua vez, foi capaz então de elevar suas concepções políticas ao patamar de consenso nacional.

Também a historiadora Miriam Dolhnikoff enfatiza a importância da década de 1840 para a estabilização do regime monárquico brasileiro: "entre 1837 e 1850 os conservadores centralizaram o aparato judiciário para permitir ao governo central um controle efetivo sobre ele, mas esse era o limite da centralização. O sentido da revisão estava em garantir a eficácia da divisão de competências e impedir que os governos provinciais seguissem invadindo as esferas de atuação do governo central, como vinham

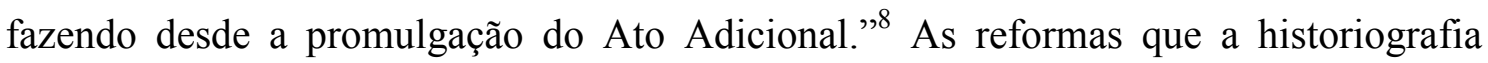
denomina de centralizadoras foram, segundo Dolhnikoff, concessões do projeto federalista vitorioso na década de 1830 ao grupo conservador que visava definir melhor a distribuição político-administrativa do poder no Império. A década de 1840 deu forma final a um pacto político que, mais do que centralizar todo o poder nas mãos de um grupo específico, se fez por meio de um arranjo federativo que concedeu autonomia administrativa para os poderes locais e definiu uma esfera de ação específica para o poder central.

Independentemente da linha interpretativa adotada, os historiadores são praticamente unânimes em reconhecer a importância do prenúncio dos novos tempos

\footnotetext{
${ }^{7}$ Ilmar R. de Mattos. O Tempo Saquarema. São Paulo: Hucitec, 2004. p. 117.

${ }^{8}$ Miriam Dolhnikoff. O Pacto Imperial: origens do federalismo no Brasil. São Paulo: Globo, 2005. p. 150 .
} 
que se deu durante a primeira década do Segundo Reinado. Na maré de mudanças que tiveram lugar então foi discutida e aprovada uma miríade de novas leis: tentou-se organizar as eleições, terminando com os atos de violência e intimidação vindos de facções desordeiras; buscou-se reorganizar a Guarda Nacional, vinculando suas patentes mais altas ao poder central; revisou-se a distribuição dos poderes entre centro e localidade; propôs-se uma nova regulamentação da propriedade territorial; reorganizouse o Poder Judiciário; estabeleceu-se um foro privilegiado para as questões comerciais; criou-se uma nova província entre São Paulo e o extremo sul do Império; fundou-se novamente o Banco do Brasil; investiu-se em infra-estrutura e na empresa nacional; buscou-se controlar o tráfico de escravos; e fez-se muito mais.

A década de 1840, em suma, se mostra como um período chave para a definição dos rumos da política nacional: de uma perspectiva ex post facto é possível dizer que ela marcou uma inflexão histórica, definiu claramente um antes e um depois. Naquele momento, o regime monárquico constitucional se estabilizava, os conflitos internos eram resolvidos e as instituições se (re)definiam, tomando a forma que proporcionariam a relativa paz interna que a monarquia brasileira desfrutou até 1889 . Enquanto, em meados do XIX, muitas nações americanas eram dilaceradas por conflitos internos como foi, por exemplo, o caso dos Estados Unidos nas décadas de 1850 e $1860^{9}$ - o Brasil tinha encontrado uma forma legítima de resolver a disputa entre interesses políticos divergentes presentes no seio de suas elites. Eventos disruptivos da ordem político-social como a Confederação do Equador (1824), a Guerra dos Cabanos (18321834), a Cabanagem (1835-1840) e a Sabinada (1837-1838) passaram a fazer parte do passado quando as últimas grandes rebeliões - a Balaiada (1838-1841), a Farroupilha (1835-1845), os Levantes Liberais (1842) e a Revolução Praieira (1848) - foram abafadas pelo Estado Nacional por meio da força e da negociação. A década de 1840, conforme reconhece a historiografia, foi um período que colocou ponto final na tendência de facciosismo que ameaçava o pacto nacional. A partir de então tanto a população pobre quanto as elites locais se curvaram - por bem ou por mal - à lógica do regime monárquico constitucional.

A contribuição que a presente dissertação visa trazer para a historiografia preocupada com a consolidação do regime monárquico no Brasil dar-se-á por meio da análise da influência que a atividade peticionária do início do Segundo Reinado teve

\footnotetext{
${ }^{9}$ Eric Foner. Free Soil, Free Labor, Free Men. The ideology of the Republican Party before the Civil War. Nova York/Oxford: Oxford University Press, 1995.
} 
sobre o processo legislativo que formulava e reformulava as instituições nacionais. Para isto, será aqui adotado o seguinte pressuposto do historiador Pierre Rosanvallon: "faire l'histoire de l'État consiste à analyser les conditions dans lesquelles se sont formées des figures du rapport État/société. Car il n'y a pas d'histoire de l'État hors de la saisie d'une relation: l'État n'existe que par rapport à la société." ${ }^{\prime 0}$ De acordo com este historiador, o Estado nada mais é do que uma instituição emanada da sociedade e, assim, não pode ser satisfatoriamente compreendido se uma dicotomia entre os dois fatores for estabelecida a priori. Conclui-se, junto de Rosanvallon, que somente por meio da compreensão do ininterrupto diálogo estabelecido entre o que se convencionou chamar de Estado e o que se convencionou denominar sociedade civil será possível encontrar respostas satisfatórias para as problemáticas levantadas pela história política.

A partir da concepção de história política defendida por Rosanvallon, as petições se tornam um importante objeto de análise, pois colocam frente a frente governantes e governados: elas explicitam a inescapável relação Estado/sociedade. As petições estiveram inseridas no citado processo de estabilização política do Império, chegando mesmo a influenciar o debate parlamentar acerca de temas como a reforma judiciária, a criação da província do Paraná, o incentivo a empresas nacionais, o combate às fraudes eleitorais, o tráfico de escravos, o Código Comercial etc.: esta influência é exatamente o tema da minha dissertação. O estudo que empreendi teve como principal objetivo compreender a relação entre o debate parlamentar acerca de algumas das mais candentes questões políticas do início do Segundo Reinado e a atividade peticionária de certos setores da sociedade brasileira. Neste sentido, o presente trabalho não se debruçará sobre o significado de uma ou outra reforma ou projeto de lei; mas buscará compreender como as iniciativas e os posicionamentos dos legisladores brasileiros - mais especificamente dos membros da Câmara dos Deputados - estiveram relacionados com a expressão dos interesses dos governados por intermédio das petições.

Para este estudo foi adotada uma metodologia que pudesse estabelecer as relações entre o discurso peticionário e a atividade parlamentar que se desenrolou nos primeiros anos do Segundo Reinado. A historiografia que se dedica à análise das petições adota basicamente dois métodos de análise: o quantitativo e o qualitativo. A análise serial das petições normalmente tem por objetivo compreender de maneira geral as demandas que a sociedade governada dirigiu às autoridades instituídas, podendo

\footnotetext{
${ }^{10}$ Pierre Rosanvallon. L'État en France: de 1789 à nos jours. Paris : Éditions du seuil, 1992. p. 15.
} 
também proporcionar relevantes dados acerca de quais grupos sociais utilizaram-se deste mecanismo de ação política. A partir da análise e sistematização de inúmeras petições, o método quantitativo provê ao historiador um quadro amplo da atividade peticionária de um período relativamente longo. A tendência é que uma análise como esta deixe de lado detalhes que diferenciam uma petição de outra e enquadre-as em categorias amplas que possam ser manipuladas pelo historiador. Já o método qualitativo tende a enfatizar o conteúdo de cada uma das petições, buscando nos documentos a interpretação que os peticionários faziam do contexto político em que estavam inseridos e a forma pela qual construíam seus argumentos com o objetivo de obter sucesso para suas demandas. Este segundo tipo de análise impõe ao historiador uma seleção prévia dos documentos a serem analisados, fato que acaba por prejudicar uma leitura generalizante da atividade peticionária de um determinado período. ${ }^{11}$

Como o objetivo do presente trabalho é relacionar a atividade peticionária com a estabilização do regime político do Império, o método qualitativo será privilegiado. Algumas petições serão escolhidas em detrimento de outras e, infelizmente, a elaboração de um quadro geral terá de esperar por um trabalho futuro. A escolha dos documentos e da forma de analisá-los tem uma só justificativa: demonstrar que, quando em pauta determinados assuntos de grande importância para a política nacional do início do Segundo Reinado, a Câmara dos Deputados e alguns setores da sociedade brasileira estabeleceram um diálogo intenso. O regime representativo se caracterizou durante o século XIX por colocar em contato de maneira regulada governantes e governados; pretendo doravante mostrar que este contato, ainda que com especificidades relevantes, também foi possível dentro da monarquia constitucional brasileira. Caso este simples objetivo seja alcançado, minha pesquisa de mestrado terá sido bem-sucedida, apontando para o fato de que no seio do regime brasileiro oitocentista havia um canal que tornava a construção das instituições nacionais uma atividade aberta a influências que transcendiam às vontades de um estamento dono do poder.

Esta dissertação será organizada da seguinte forma: o capítulo 1 tratará do direito de petição dentro dos regimes representativos na virada do século XVIII para o XIX, recorrendo para este fim ao debate teórico e a exemplos históricos; o capítulo 2 terá como tema a tradição peticionária herdada pelo Brasil oitocentista - empreender-se-

\footnotetext{
${ }^{11}$ Para uma amostra da variedade de formas de se utilizar petições como documento histórico: Lex Heerma van Voss (ed.). Petitions in Social History. International Review of Social History. Volume 41, suplemento 9. Nova York: Cambridge University Press, 2001.
} 
á aí uma breve análise das petições no Antigo Regime português e em sua colônia americana, uma discussão da bibliografia sobre atividade peticionária no Primeiro Reinado e uma também breve explicação da ruptura histórica que as petições do início do Segundo Reinado trouxeram àquela atividade no Brasil; os capítulo 3, 4 e 5 tratarão de grupos específicos de petições e de sua relação com o debate parlamentar - no capítulo 3 o objeto será o problema da corrupção eleitoral e sua repercussão em eventos como a dissolução da Câmara em 1842 e a reforma eleitoral de 1846; no capítulo 4 o tema será a influência da atividade peticionária das associações comerciais do Rio de Janeiro, Recife e Salvador sobre a aprovação do Código Comercial Brasileiro; no capítulo 5 será examinada a oposição das câmaras municipais paulistas e mineiras à Lei de 03 de dezembro de 1841 e o conseqüente debate parlamentar acerca de uma reforma judiciária. Por fim, breves considerações finais. Cabe aqui ressaltar que os temas dos capítulos 3, 4 e 5 foram definidos de acordo com a relevância que cada grupo de petição adquiriu para o debate parlamentar. 


\section{CAPÍTULO 1. OS NOTÁVEIS E A NAÇÃO: O DIREITO DE PETIÇÃO SOB O REGIME REPRESENTATIVO}

O regime representativo foi compreendido por alguns teóricos da política como uma forma democrática de governo adaptada aos Estados Nacionais de grandes dimensões territoriais e populacionais que surgiram no período moderno da história. $\mathrm{O}$ cientista político Bernard Manin, no entanto, defende um ponto de vista diferente: segundo ele, “ce que l'on désigne aujoud'hui sous le nom de démocratie représentative trouve ses origines dans les instituitions qui se sont progressivement établies et imposées en Occident à la suite des trois révolutions modernes, les révolutions anglaise, américaine et française. Or ces instituitions n’ont nullement été perçues, à leurs débuts, comme une variété de la démocratie ou une forme du gouvernement par le peuple." ${ }^{2}$ Ainda que permitisse a participação da população na política nacional, o regime representativo foi concebido, entre os séculos XVIII e XIX, como uma forma marcadamente aristocrática de governo. Vivia-se, então, um período de grande inovação política em alguns países do Ocidente: foi sob este contexto de mudanças que o regime representativo ganhou sua primeira formulação.

$\mathrm{Na}$ Inglaterra da segunda metade do século XVIII, por exemplo, acontecimentos importantes se deram em torno de um jornalista e parlamentar radical chamado John Wilkes. Sua popularidade entre alguns cidadãos londrinos teve início quando, no ano de 1763, foi publicado o número 45 de seu jornal The North Briton: nele, o agitador criticava a fala real perante o parlamento britânico na qual um balaço positivo havia sido feito em relação ao Tratado de Paris (que colocava termos finais à Guerra dos Sete Anos). Em retaliação à ofensa contra a Coroa, Wilkes foi preso na Torre de Londres e o sheriff da cidade tentou incendiar em praça pública o famigerado número 45 de seu jornal. Apenas tentou, pois uma multidão enfurecida atacou a autoridade e o carrasco a seu serviço, conseguindo tomar-lhes o exemplar condenado, e passou a desfilar pelas ruas da capital sob gritos de "Wilkes and Liberty". ${ }^{13}$

Animado pela demonstração de apoio, Wilkes, logo ao sair da cadeia, republicou o número 45 e ainda se dedicou a panfletos pornográficos com forte conteúdo político. Expelido do parlamento e sentenciado à prisão mais uma vez, Wilkes deixou a Inglaterra; seus seguidores, no entanto, passaram a venerá-lo ainda com mais fervor.

\footnotetext{
${ }^{12}$ Bernard Manin. Principes du Gouvernement Représentatif. Paris: Flammarion, 1996. p. 11.

${ }^{13}$ Charles Tilly. Popular Contention in Great Britain, 1758-1834. Cambridge/Londres: Harvard University Press, 1995. p. 151.
} 
Diversos setores descontentes da população londrina tomaram Wilkes como um herói. No ano eleitoral de 1768 Wilkes estava de volta: apesar de o sufrágio ser restrito às classes proprietárias na Inglaterra setecentista, os partidários de Wilkes apelaram para o apoio das massas e para ideais de soberania popular. Todos aqueles que fossem considerados inimigos do agitador tinham as janelas de suas casas apedrejadas e suas carruagens interceptadas; operários, principalmente os das tecelagens de Spitalfields, organizaram greves e atacaram autoridades infensas ao líder radical; demonstrações próWilkes tomaram as ruas de Londres e chegaram às portas do parlamento. Enfurecidas pelas demonstrações, as autoridades aprisionaram Wilkes novamente e anularam sua eleição. No dia 10 de maio, uma turbamulta cercou a prisão onde seu herói se encontrava e exigiu sua libertação. Tropas do governo atacaram os manifestantes, fazendo cerca de sete vítimas fatais. O Massacre de St. George's-Field - como ficou conhecido o evento - chocou boa parte dos comentaristas da época. ${ }^{14}$

No ano de 1769, ainda na prisão, Wilkes foi eleito vereador da cidade de Londres. Nos anos seguintes, foi eleito para a Casa dos Comuns por quatro vezes consecutivas; todas as eleições foram anuladas pelo próprio parlamento. As anulações, entretanto, trouxeram ainda mais oportunidades para seus adeptos se manifestarem e reafirmarem seus ideais de soberania popular. Em 1770, Wilkes foi libertado e logo em 1771 foi eleito sheriff de Londres; em 1774 foi nomeado Lord Mayor e no mesmo ano foi novamente eleito (e agora aceito) para o parlamento. As ruas da cidade, neste período turbulento, eram tomadas a cada aparição pública de Wilkes: em meio às demonstrações de apoio ao panfletista, contestações contra o elitismo do parlamento se tornavam cada vez mais freqüentes e causavam arrepios na elite política. O impacto da comoção popular sobre a opinião pública londrina foi tamanho que mesmo aqueles que abjuravam os métodos dos radicais viram-se forçados a adotar expedientes muito parecidos com os seus. No dia 22 de março de 1769, por exemplo, os principais comerciantes de Londres tomaram as ruas em direção ao palácio real onde entregaram um documento em que rejeitavam todo tipo de sedição popular e se declaravam fiéis ao monarca. Os partidários de Wilkes interceptaram a passeata e uma confusão generalizada tomou a cidade. ${ }^{15}$

Apesar de restritos, os acontecimentos em torno de John Wilkes foram muito significativos dentro do contexto em que se deram. Pela primeira vez na história inglesa,

\footnotetext{
${ }^{14}$ Idem. Ibidem. pp. 152-157.

${ }^{15}$ Idem. Ibidem. pp. 157-158.
} 
pessoas comuns visavam influenciar a política nacional sem, contudo, colocar abaixo toda a estrutura existente, como ocorrera no século XVII. Segundo explica o sociólogo Charles Tilly, "although Wilkes himself never preached popular sovereignty, indeed resisted diversion of the discussion from his own grievances, he became a symbol of ordinary people's rights to hold their rulers accountable." ${ }^{\prime 16}$ Dentro de um contexto de grandes transformações sociais, culturais e econômicas, os partidários de Wilkes se utilizaram de associações voluntárias para transformar a esfera política nacional. Daquele momento em diante, muitos cidadãos britânicos tomaram consciência de que sua ação coletiva podia pressionar os governantes em prol de uma causa. Do grupo de aliados de Wilkes nasceu a Society of Supporters of the Bill of Rights que lutava por profundas reformas parlamentares. Além desta importante associação, abriram-se novas oportunidades políticas para outros grupos dissidentes na Inglaterra: em 1779 a Protestant Association, liderada por Lord George Gordon, organizou um movimento pela exclusão dos católicos da vida pública britânica. Com a finalidade de demonstrar a força de sua causa, 50.000 destes anti-católicos tomaram o mesmo St. George's-Field em que os aliados de Wilkes haviam sido massacrados; no mesmo dia, casas e carruagens de parlamentares acusados de papismo foram atacadas. Quando o descontentamento se espalhou pela cidade e se mostrou resistente, tropas do governo atacaram os manifestantes e mataram 257 pessoas; ainda assim, levaram uma semana para conter o tumulto. ${ }^{17}$

O sangue que lavou as ruas de Londres na segunda metade do século XVIII também foi derramado do outro lado do Atlântico quando os habitantes das treze colônias decidiram que não mais se submeteriam a George III e ao corrupto parlamento britânico. No entanto, o problema político mais complexo a ser resolvido pelos "founding fathers" era interno. Nas palavras do historiador Gordon S. Wood, "what alarmed the gentry of the 1760 s and 1770 s (...) were the growing ideologically backed claims by ordinary people to a share in the actual conduct of government." ${ }^{, 18}$ Artesãos desenvolveram, nos anos de conflito com a Inglaterra, um novo senso de identidade coletiva e começaram a falar abertamente de um "interesse mecânico" distinto de outros interesses da sociedade americana. Assim também fizeram grupos étnicos, como os alemães da Filadélfia, e seitas religiosas radicais. "They wanted to make governmental

\footnotetext{
${ }^{16}$ Idem. Ibidem. p. 158.

${ }^{17}$ Idem. Ibidem. pp. 159-162.

${ }^{18}$ Gordon S. Wood. The Radicalism of the American Revolution. Nova York: Vintage Books, 2003. p. 244.
} 
decision for themselves," - explica Wood - "and they now called for explicit representation of interests in government." ${ }^{\text {"19 }}$ Estes grupos de homens comuns criaram formas de eleger candidatos dentre os seus, pois acreditavam que somente alguém como eles poderia de fato representá-los. Do seu ponto de vista, a aristocracia agrária, tradicional ocupante dos postos de mando, apenas governava em nome de si mesma.

Às classes proprietárias do novo país parecia um desvario que as elites educadas tivessem que consultar homens rudes e sem estudo em questões de governo. William Henry Drayton, aristocrata da Carolina do Sul, reconhecia que os trabalhadores manuais tinham importantes funções sociais a cumprir: "to cut up a beast in the market to the best advantage, to cobble an old shoe in the neatest manner, or to build a necessary house." 20 Isso não lhes dava, todavia, a mínima competência requerida para assuntos governamentais. Pior - explicava Drayton - seu profundo envolvimento com os negócios os tornava homens incapazes de divisar um interesse geral. Segundo a concepção republicana da elite da época, a política requeria uma visão de mundo liberal, desinteressada, cosmopolita - privilégio de poucos homens de propriedade, homens cujas posses permitiam a necessária educação e a administração desinteressada dos assuntos públicos. Ao explicitarem seus descontentamentos políticos, artesãos, seitas religiosas e grupos de imigrantes estavam, na visão da aristocracia, querendo impor interesses privados sobre toda a comunidade nacional. $\mathrm{O}$ alarme do grupo tradicional de governantes foi geral quando, nas palavras de Wood, "Americans virtually ceased talking about the people's 'interest' in the singular; the people's 'interests' agricultural, commercial, manufacturing - were all plural now."21

Nos anos que sucederam à Guerra de Independência, aquilo que significava libertação para os homens comuns, foi visto pela aristocracia como egoísmo e licenciosidade. As primeiras conquistas das classes populares foram as legislaturas estaduais: nelas, entendiam homens como Drayton, cada membro defendia sua casta e pouco era feito pela sociedade como um todo. Eleições anuais e aumento do número de deputados estaduais - ambas as coisas conquistas populares da época da Revolução contribuíam para que o bem público fosse pulverizado em interesses facciosos. A res publica se transformava em arena de disputa entre paroquialismos; cada representante,

\footnotetext{
${ }^{19}$ Idem. Ibidem. p. 244.

${ }^{20}$ William Henry Drayton apud Idem. Ibidem. p. 246.

${ }^{21}$ Idem. Ibidem. p. 247.
} 
para o desespero dos mais ilustrados, falava em nome de seus eleitores apenas, utilizando meios públicos para obter fins privados. $^{22}$

$\mathrm{Na}$ França revolucionária, as transformações políticas do fim do XVIII se fizeram sentir de modo dramático. Também lá se desenrolou o debate acerca dos interesses particulares e da vontade geral: segundo a historiadora Lynn Hunt, na França “política faccionária era sinônimo de conspiração, e 'interesse' era eufemismo para traição da nação unida. Nada que fosse particular (e todo 'interesse' era, por definição, particular) deveria dividir a vontade geral. A vigilância constante e o caráter público de toda a política eram os modos de impedir o aparecimento de interesses particulares e facções." ${ }^{23}$ Os revolucionários, que de um só golpe haviam derrubado o Antigo Regime, acreditavam que a nação francesa soberana - única e indivisível - deveria conduzir o Estado; este era o sentido da Revolução. Todo aquele que fosse considerado inimigo da pátria francesa deveria ser punido exemplarmente; assim, os tribunais revolucionários se incumbiam de inúmeros e detalhados exames dos atos políticos de cada indivíduo. A guilhotina deu concretude à teoria da vontade geral.

Frente à resistência monarquista e à invasão estrangeira, os franceses tiveram de elaborar estratégias de defesa para garantir sua existência como nação soberana. "A luta entre a nação francesa regenerada e seus supostos inimigos" - explica Hunt - "foi particularmente divisiva devido à combinação de ineditismo da mobilização política, intensidade do antagonismo social (...) e ênfase sem precedentes em fazer algo totalmente novo no mundo." 24 As denúncias se tornaram o artifício político por excelência da França revolucionária, um dever cívico daqueles que vigiavam pela segurança nacional. $\mathrm{O}$ combate aos supostos traidores da pátria unia os franceses em defesa de sua soberania. O preço de tal defesa foram os expurgos que, de maneira ininterrupta, conduziram a política francesa da queda da Bastilha até a ascensão de Bonaparte. Estabelecera-se no maior país da Europa ocidental, entendiam os críticos da época, a sempre temida tirania da maioria. ${ }^{25}$

A Revolução foi responsável por uma brusca transição da restrita política do Antigo Regime para a ampla participação popular: "a política dali por diante não dizia respeito a ministros, parlamentos, constituições, interesses ou governo, mas à própria

\footnotetext{
${ }^{22}$ Idem. Ibidem. pp. 250-251.

${ }^{23}$ Lynn Hunt. Política, Cultura e Classe na Revolução Francesa. São Paulo: Companhia das Letras, 2007. p. 67.

${ }^{24}$ Idem. Ibidem. p. 66.

${ }^{25}$ Consultar, por exemplo, a obra de Edmund Burke datada de 1790: Reflection on the Revolution in France. Stanford: Stanford University Press, 2001.
} 
natureza das relações sociais. A política não era uma arena para a representação de interesses concorrentes. Era um instrumento para reestruturar a natureza humana, transformar súditos em cidadãos, escravos em homens livres, oprimidos em republicanos." 26 O radicalismo revolucionário transformava o cerne da política nacional, colocava-a nas mãos da nação francesa imbuída, idealmente, de uma só vontade. Mas que vontade era esta? Como defini-la? Todos aqueles que quiseram responder caíram em desgraça. Segundo os próprios revolucionários, a coletividade não podia ser representada, devendo agir por conta própria, sem peias impostas por líderes, partidos, sociedades ou assembléias. Da perspectiva dos inimigos da Revolução e também dos revolucionários mais moderados, o Estado francês fora feito refém da multidão.

Como ficou exposto acima, o final do século XVIII foi um tempo de profunda transformação política em países como Inglaterra, Estados Unidos e França. Homens comuns se transformaram em atores políticos e as elites que tradicionalmente haviam governado foram desafiadas de forma explícita. Com maiores ou menores doses de sangue derramado, os britânicos, os norte-americanos e os franceses revolucionaram o modo pelo qual a política seria conduzida no Ocidente a partir de então. Ainda que diferissem em importantes concepções políticas, os operários da Inglaterra que gritaram "Wilkes and Liberty", os artesãos que elegeram seus pares para as legislaturas estaduais na América e as massas parisienses que presenciaram os julgamentos dos traidores da pátria compartilhavam uma concepção básica: o controle da política devia pertencer aos cidadãos e não mais à tradicional aristocracia. Ainda que a atuação política da nação fosse concebida de modos díspares - como o direito de defender lideranças políticas (no caso inglês), ou como o agregado de diversos interesses privados (no caso norteamericano), ou ainda como uma vontade indivisível (no caso francês) - o que começava a ser pregado ao fim dos setecentos era a direta influência da sociedade governada sobre os atos dos governantes. Um tempo de conflito se inaugurava em determinados países do mundo ocidental à medida que os movimentos da sociedade se tornavam mais e mais radicais: frente à atuação dos governados, os governantes e os teóricos da política procuravam os termos que poderiam dar estabilidade ao Estado sem, no entanto, correr o risco de agitar ainda mais a massa de cidadãos. Nascia a teoria do regime representativo.

\footnotetext{
${ }^{26}$ Lynn Hunt. Op. Cit. p. 72.
} 
Refletindo sobre a política em meio à transformação, Edmund Burke se tornou uma das influências intelectuais mais importantes da política ocidental a partir do fim do século XVIII. Para Burke, numa sociedade bem ordenada, o ato de governar deveria caber a uma elite esclarecida, preparada para lidar com as verdadeiras necessidades de uma nação complexa. Acreditava ele que, caso o poder político repousasse nas mãos da multidão - estivesse ela unida ou dividida em facções -, seria impossível estabelecer uma direção razoável para os assuntos públicos já que as paixões imediatistas dos cidadãos comuns inviabilizariam qualquer acordo. Por isso, os representantes da nação deveriam diferir da multidão, possuindo aptidões superiores, sabedoria para legislar sobre a comunidade nacional como um todo. A missão política da elite governante seria descobrir as leis de Deus e da natureza sem, contudo, partir de pressupostos universais como haviam feito os philosophes da França setecentista. O homem de Estado deveria ligar-se à razão prática, ao conhecimento dos problemas e dos interesses reais dos governados, contudo não poderia jamais ser influenciado pelos particularismos e pelas paixões de seus constituintes: somente assim estaria apto a exercer a atividade deliberativa e elaborar leis que se adequassem ao bem comum. ${ }^{27}$

O interesse da nação não se confundia, para Burke, com a vontade imediata dos governados. Como dizia, no ano de 1774, aos seus eleitores em Bristol: "if government were a matter of will upon any side, yours without question ought to be superior. But government and legislation are matters of reason and judgment." 28 A vontade dos eleitores, por mais intensa que se mostrasse, não se constituía como parâmetro para se separar o certo do errado, o bem do mal. A opinião popular, para Burke, tinha sim sua relevância, porém somente por meio da meditação e do debate levados a cabo pela elite de governantes se poderia estabelecer o verdadeiro interesse da comunidade nacional:

to deliver an opinion is the right of all men; that of constituents is a weighty and respectable opinion, which a representative ought always to rejoice to consider. But authoritative instructions, Mandates issued, which the Member [of Parliament] is bound blindly and implicitly to obey, to vote, and to argue for, though contrary to the clearest convictions of his judgment and conscience; these are things utterly unknown to the laws of this land, and which arise from a fundamental mistake of the whole order and tenor of our Constitution.

Parliament is not a congress of ambassadors from different and hostile interests; which interests each must maintain, as an agent and advocate, against other agents and advocates; but parliament is a

${ }^{27}$ Hannah F. Pitkin. The Concept of Representation. Berkeley/Los Angeles/Londres: University of California Press, 1997. p. 169.

${ }^{28}$ Edmund Burke. "Speech to the electors of Bristol" In: Idem. The Select Works of Edmund Burke. Volume 4: Miscellaneous Writings. Indianapolis: Liberty Fund, 1999. p. 11. 
deliberative assembly of one nation, with one interest, that of the whole; where, not local purposes, not local prejudices, ought to guide, but the general good, resulting from the general reason of the whole. You choose a member indeed; but when you have chosen him, he is not member of Bristol, but he is a member of parliament. ${ }^{29}$

O parlamento nacional não poderia se comportar, em hipótese alguma, como uma assembléia de delegados obedientes às vontades da população governada. Agir com deferência a preconceitos populares seria contrariar o que Burke denominava "general good": membros de uma elite política nacional, os representantes da nação somente eles - teriam a obrigação de legislar de acordo com o interesse do todo. As manifestações públicas, segundo a teoria política burkeana, não tinham o direito de exigir que os parlamentares adotassem medidas que desagregassem a nação.

Não só o pensamento conservador burkeano foi responsável pela formulação do regime representativo como um regime de caráter eminentemente aristocrático. Os federalistas, ao elaborarem a Constituição da recém-fundada república americana, tomaram uma posição em alguns aspectos muito próxima da teoria de Burke. Para James Madison, um dos fatores que mais claramente diferenciavam uma república moderna de uma democracia antiga era que, naquela, o poder político deveria ser delegado "to a small number of citizens elected by the rest": esta diferença era intensamente desejada pelos federalistas pois teria como efeito

\begin{abstract}
to refine and enlarge the public views, by passing them through the medium of a chosen body of citizens, whose wisdom may best discern the true interest of their country, and whose patriotism and love of justice will be least likely to sacrifice it to temporary or partial considerations. Under such a regulation, it may well happen that the public voice, pronounced by the representatives of the people, will be more consonant to the public good than if pronounced by the people themselves, convened for the purpose. ${ }^{30}$
\end{abstract}

A maior preocupação de Madison era que a jovem nação caísse nas mãos de interesses facciosos e, com isso, fosse dilacerada. A melhor solução que encontrou foi a constituição de uma elite governante que, no seio de uma assembléia nacional, fosse capaz de legislar em benefício de todo o país. Segundo o estadista virginiano, "no man is allowed to be a judge in his own cause; because his interest would bias his judgment, and, not improbably, corrupt his integrity."31 Conseqüentemente, um corpo legislativo composto por poucos e ilustres cidadãos deveria ser incumbido de filtrar as demandas

\footnotetext{
${ }^{29}$ Idem. Ibidem. pp. 11-12.

${ }^{30}$ James Madison. "Federalist 10" In: Alexander Hamilton, John Jay e James Madison. The Federalist. Nova York: Barnes and Nobles, 2006. p. 56.

${ }^{31}$ Idem. Ibidem. p. 54.
} 
de cada grupo que compusesse a república, dando-lhes uma forma superior, mais ajustada à união nacional e ao bem comum. Aos cidadãos estava vetada a participação direta nas decisões de Estado já que o choque de seus preconceitos - "temporary or partial considerations" - poderia levar o país ao abismo. Havia, no pensamento madisoniano, uma flagrante desconfiança da capacidade de autogoverno por parte dos cidadãos comuns; sendo assim, o direito único dos representantes se justificava "as a defence to the people against their own temporary errors and delusions." ${ }^{, 32}$

Entre alguns revolucionários franceses o regime representativo se mostrou como uma solução para o impasse em que se encontrava o país após a queda da Bastilha, ou seja, para a onda de temor, denúncias, julgamentos e condenações que tomava os revolucionários. $\mathrm{O}$ abade Emmanuel-Joseph Sieyès, num discurso composto no calor do momento, propunha que uma assembléia tivesse o direito exclusivo de legislar sobre a nação francesa, representando, num órgão oficialmente instituído, as aspirações da nação que emergia da turbulência revolucionária. A Assembléia Nacional, que então se constituiria, deveria zelar por todos os assuntos que dissessem respeito à vontade geral da nação francesa. Todos aqueles que se submetessem ao pacto político deveriam estar de acordo com a deliberação da maioria dos parlamentares.

A mesure que le nombre des Citoyens augmente, il leur devient dificille, impossible même de se réunir pour confronter les volontés particulières, pour les concilier et connoître le voeu général. Il faut donc que la communauté se partage en plusieurs districts, et que chaque division commette quelques-uns des associés pour porter son vote a un rendez-vous commun. Mais bientôt on reconnoît que la méthode de détacher des simples porteurs de votes est essentiellement vicieuse, en ce que les Députés, obligés de s'en tenir scrupuleusement à l'avis de leurs commetans, ne pouvant point se concilier entr'eux, il devient souvent impossible de tirer de la totalité des votes une volonté commune: or ce la volonté commune qu'il faut; et tout moyen qui ne la donne pas, est radicalement mauvais. On doit sentir que s'il falloit consulter de nouveau les commetant des différens districts, leur faire part de ce qui se passe, attendre de nouveaux ordres, et recommencer cette même marche, tant que les avis ne présenteroient point encore une volonté commune, on doit sentir que les affaires ne finiroient pas, que l'intérêt public en souffriroit, et que le généralité des associés, pour vouloir se réserver trop immédiatement l'exercice de leur volonté, s'en interdiroit l'usage. ${ }^{33}$

\footnotetext{
${ }^{32}$ Idem. "Federalist 63" In: Idem. Ibidem. p. 349.

${ }^{33}$ Emmanel-Joseph Sieyès. Vues sur les moyens d'execution dont les représentans de la France pourront disponer en 1789. pp. 19-20. Disponível no endereço eletrônico: http://gallica.bnf.fr/ark:/12148/ bpt6k41688x.image.r=sieyès.f5.langPT. Acessado em 01 de junho de 2009.
} 
Aos representantes de cada distrito da França caberia levar os votos da comunidade à reunião geral dos legisladores. Não obstante, sua função não se resumiria a uma simples delegação; pelo contrário, uma vez reunidos, os deputados deixariam de ser representantes de cada distrito para agir em nome da nação francesa ("la volonté commune"). Revolucionário, Sieyès compartilhava a idéia de que a nação francesa era indivisível, porém, diferentemente da maioria dos seus pares, acreditava que ela podia agir indiretamente, pela deliberação de seus representantes. A representação política era uma solução para a impossibilidade dos cidadãos definirem, por si mesmos, a vontade geral. Sieyès foi derrotado: o terror jacobino, o terror branco do Diretório, a ditadura bonapartista e diversos golpes e levantes transformaram a virada do XVIII para o XIX em anos de constante guerra civil e expurgos políticos na França. Não obstante, seu ideal prevaleceu no século XIX e deu base para diversos regimes políticos que nasciam no Ocidente.

A teoria do regime representativo agradava às elites governantes do mundo ocidental pois fornecia, a um só tempo, solução à pressão popular ao estilo britânico, ao facciosismo das classes trabalhadoras norte-americanas e ao governo da multidão estabelecido pelos revolucionários franceses. De acordo com os teóricos do regime representativo, a obediência estrita às vontades dos governados traria como conseqüência inevitável a confusão entre idiossincrasias ideológicas, regionais ou classistas. Apesar de guardarem diferenças fundamentais entre si, os formuladores do regime representativo eram unânimes em um ponto: consideravam os cidadãos comuns incapazes de governarem a si mesmos. Mesmo que imbuídos de ideais como soberania popular ou nacionalismo, os cidadãos não conseguiriam chegar a um acordo acerca do que verdadeiramente fosse melhor para o país como um todo. A vontade geral não emanaria naturalmente da atuação dos populares, mas seria resultado da deliberação racional de um corpo eleito de representantes.

O ideal de soberania popular foi um dos fundamentos do pensamento político de autores como Burke, Madison e Sieyès; porém, como aponta o cientista político Adam Przeworski, na teoria política de finais do século XVIII, o povo aparecia sempre no singular. Deste modo, não seriam os cidadãos por si mesmos que governariam, mas sim uma entidade abstrata - o povo. Uma solução para este quebra-cabeça foi a representação: somente um corpo de homens escolhidos especialmente para legislar poderia estabelecer o verdadeiro interesse nacional, os representantes da nação dariam a última palavra sobre a vontade do povo. "The founders of representative institutions" - 
explica Przeworski - "could see no middle road between consensus and civil war, harmony and mayhem. ${ }^{, 34} \mathrm{O}$ espectro da dissolução nacional pairava, no fim do século XVIII, sobre importantes regiões do mundo ocidental: o regime representativo surgia como um meio de se harmonizar a complexa relação que se estabelecia entre governantes e governados.

Para que a harmonia fosse possível, o legislador deveria sustentar sempre o caráter consensual das decisões políticas, deixando de lado tudo que fosse considerado paixões particulares. O Estado Nacional deveria sempre se mostrar como a fortaleza da vontade geral. De acordo com Przeworski, "representative government in the West was thus born under an ideology that postulated a basic harmony of interests in society." 35 Segundo a concepção dos idealizadores da representação política, uma sociedade nacional deveria ser cimentada por valores e interesses comuns, sendo que divisões ideológicas, socioeconômicas e regionais deveriam ser sobrepujadas na arena política por uma verdade superior e unificadora. Esta verdade só poderia ser encontrada por meio da deliberação de uma assembléia de notáveis reunida exclusivamente para tal fim: o papel do representante eleito pela nação seria, frente aos diversos conflitos sociais, identificar e implementar o interesse nacional. Para que isso ocorresse, ele deveria ser um homem guiado apenas pela razão e pela virtude, afastado das paixões. No seio do parlamento nacional, em meio a seus pares, ele deixaria de ser representante de um ou outro grupo para se tornar representante da nação como um todo. Divisões políticas provenientes de interesses idiossincráticos, com seu caráter apaixonado e irracional, se mostravam como a hidra a ser derrotada pelos representantes da nação. Homens como Madison, Sieyès e mesmo Burke não negavam o fato evidente de que as pessoas podiam discordar entre si com relação aos mais variados assuntos. Entretanto, o pressuposto de sua argumentação era que existiam, sim, interesses comuns a todos os grupos da sociedade e que estes deveriam guiar a construção das instituições nacionais.

Os idealizadores do regime representativo compreendiam o povo como um corpo; e um corpo, sabia-se, não poderia sobreviver - pelo menos não de forma saudável - sem que suas partes agissem de modo harmonioso. Esta analogia surgida no mundo medieval ganhava um novo sentido no fim dos setecentos: o temor, naquele momento, era que facções emanadas da sociedade interferissem na atividade legislativa,

${ }^{34}$ Adam Przeworski. "Consensus and Conflict in Western thought on representative government". Conferência apresentada junto ao Beijing Forum. Beijing: 2006. Disponível no endereço eletrônico: http://politics.as.nyu.edu/docs/IO/2800/beijing-ba.pdf. Acessado em 13 de dezembro de 2009. p. 3.

${ }^{35}$ Idem. Ibidem. p. 2. 
criando conflitos incontroláveis que desintegrassem a unidade nacional. Não houve poucos casos em que o descontentamento dos cidadãos em relação à obra de seus governantes foi tomado como subversivo e ilegítimo. Conforme diz Przeworski, "the notion that people can freely oppose the government elected by a majority emerged only gradually and painfully everywhere, the United States included. (...) And the insistence on delegating governance to the illustrious few, on excluding the people from governing, remained at the core of liberal thought, from Montesquieu to [John Stuart] Mill." ${ }^{, 36}$ Uma assembléia nacional, formada por homens notáveis, não deveria obedecer às idiossincrasias deste ou daquele grupo de cidadãos. A esclarecida atividade deliberativa dos representantes deveria evitar que os conflitos sociais tomassem a arena política e levassem os diversos setores da nação a um conflito fratricida. A estabilidade dos novos regimes que surgiam na virada do século XVIII para o XIX dependia do controle das vontades e paixões populares e da formulação, por parte de cidadãos iminentes, de um interesse que realmente soasse como nacional.

Estrategicamente elaborado como resposta à crescente e ameaçadora atividade política de cidadãos comuns, o discurso da vontade geral justificava a ação da elite política e vedava a participação direta da multidão no governo nacional. Todavia, as elites incumbidas da alta missão de estabelecer o interesse nacional precisavam, antes de mais nada, legitimar seu poder. Com o esfacelamento da sociedade de Antigo Regime, caberia aos próprios governados - ou à sua parte considerada mais importante - definir quem realmente tinha capacidade para representar a nação. Assim, o procedimento eleitoral foi tomado pelos criadores do regime representativo como o modo de delegar ao legislador o direito de definir o bem comum. As eleições de representantes da nação se transformaram num elemento central da política ocidental, pois permitiram a participação popular na política e, ao mesmo tempo, salvaguardaram o caráter aristocrático do regime. O governo era do povo, mas o povo delegava-o a um corpo de representantes por intermédio do voto.

Em Principes du Gouvernement Représentatif, Manin demonstra que na teoria política clássica o sorteio representava a forma democrática por excelência para a escolha de governantes enquanto o método eleitoral esteve sempre ligado ao governo aristocrático. Em suas palavras: “on peut sans doute faire valoir que, dans une procédure élective, tous les candidats n'ont pas des chances égales d'accéder aux charges, par ce

\footnotetext{
${ }^{36}$ Idem. Ibidem. p. 16.
} 
que leur élection dépend de leurs mérites aux yeux de leurs concitoyens et que tous ne possèdent pas au même degré les qualités prisées par les autres." ${ }^{, 37} \mathrm{O}$ processo eleitoral se ligava à crença de que as honras e o poder deveriam ser distribuídos conforme os méritos de cada um, e não ao acaso. A elite governante de um regime representativo fundamentava seu poder sobre o consentimento da sociedade governada, mas não se confundia com ela; o cidadão elegia, mas não legislava.

Somente o processo eleitoral poderia casar com a concepção - caudatária das revoluções modernas - de que a sociedade não seria mais obrigada a consentir com um governo que não emanasse da vontade popular e que não fosse competente para exercer as funções públicas. Diferentemente do que aconteceria caso fosse adotado o sorteio método pelo qual homens sem reconhecimento social poderiam ascender aos postos de mando - as eleições permitiam que apenas aqueles considerados pela maioria dos eleitores como verdadeiros notáveis exercessem poder político sobre a nação. Enquanto o sorteio deixaria os governados à mercê da sorte, as eleições faziam triunfar a vontade humana sobre as questões políticas. No período de formação dos regimes representativos no Ocidente, as eleições se mostraram como o método mais eficaz de se elevar aos parlamentos nacionais os homens mais preparados para elaborar uma legislação adequada à época e ao povo. ${ }^{38}$

A adoção do método eleitoral derivou do fato dos fundadores do regime representativo não desejarem que os representantes fossem semelhantes aos representados. Queriam, conforme ficou dito, um governo de notáveis e, por isso, adotaram a eleição como o meio de elevar ao poder indivíduos politicamente superiores aos demais, indivíduos portadores de mérito. "Le gouvernment représentatif a été institué” - explica Manin - "avec la claire conscience que les représentants élus seraient et devaient être des citoyens distingués, socialement distincts de ceux qui les élisaient." 39 Sendo assim, ao se reunirem numa assembléia nacional, estes cidadãos socialmente reconhecidos como notabilidades políticas teriam legitimidade para definir o que seria, a partir de então, reconhecido como a vontade geral de uma nação.

Uma aristocracia, mas uma aristocracia democrática: assim Bernard Manin define os representantes da nação - "le type d'aristocratie auquel l'élection se reliait n'avait rien à avoir avec une noblesse légalement définie et héréditaire. S'il est vrai que

\footnotetext{
${ }^{37}$ Bernard Manin. Op. Cit. p. 60.

${ }^{38}$ Idem. Ibidem. pp. 113-116.

${ }^{39}$ Idem. Ibidem. p. 125.
} 
l'élection favorise les Grands, ce ne sont pas les Grands de la societé d'ordres, mais ceux qui jouissent d'un statut supérieur dans la société, en quelques termes que soit définie cette supériorité." 40 Sob o regime representativo, o acesso ao parlamento nacional não exigia qualquer condição prévia: os escolhidos assim o eram apenas pela vontade dos eleitores. O procedimento eleitoral - não o estatuto de nascimento definiria quem poderia ou não fazer parte elite governante. $\mathrm{O}$ mérito de cada um dos candidatos seria julgado pelo corpo eleitoral e mesmo que neste julgamento pesassem questões tradicionais (como linhagem familiar, por exemplo), seriam os eleitores os definidores únicos de seu critério de escolha. O que verdadeiramente contava para a seleção de um representante era a percepção do representado sobre o que se caracterizava como superioridade no contexto social em que estava inserido. $\mathrm{O}$ legislador, a partir do surgimento do regime representativo, tinha obrigatoriamente sua origem numa eleição. Era este procedimento que lhe dava a legitimidade para definir livremente o interesse nacional.

A formulação, cara ao regime representativo, segundo a qual ao povo - ou a uma parte dele - cabia votar e aos eleitos cabia legislar, não impediu que essa forma de governo incorporasse meios populares de expressão política. Muito pelo contrário, eles floresceram de modo inédito na realidade política ocidental a partir da consolidação dos regimes representativos: a relação de representação não se estabeleceu como um mero vínculo eleitoral; meios de expressão daquilo que se convencionou chamar opinião pública estabeleceram um diálogo entre representantes e representados. O imemorial direito de petição, por exemplo, foi reafirmado pelas constituições políticas que surgiram a partir do último quartel do século XVIII e ganhou novos significados a partir da apropriação da sociedade governada. Nos Estados Unidos da América, a primeira emenda da Bill of Rights (1791) dizia que o Congresso "shall make no law respecting an establishment of religion, or prohibiting the free exercise thereof; or abridging the freedom of speech, or of the press; or the right of the people peaceably to assemble, and to petition the Government for a redress of grievances." 41 Do mesmo modo, a Constituição monárquica francesa de 1791 assegurava aos cidadãos "la liberté d'adresser aux autorités constituées des pétitions signées individuellement." ${ }^{\text {,2 }}$ Também

\footnotetext{
${ }^{40}$ Idem. Ibidem. pp. 172-173.

${ }^{41}$ Bill of Rights. Disponível no endereço eletrônico: http://www.archives.gov/exhibits/charters/bill_of_rights.html. Acessado em 13 de janeiro de 2010.

${ }^{42}$ Constitution de 1791. Disponível no endereço eletrônico: http://mjp.univ-perp.fr/france/co1791.htm. Acessado em 26 de agosto de 2009.
} 
a Constituição do Brasil imperial garantia pelo Artigo 179 - "dos direitos civis e políticos do cidadão brasileiro" - o direito popular de se fazer ouvir pelas autoridades estatais: lê-se, no parágrafo 30, que “todo o cidadão poderá apresentar por escrito ao Poder Legislativo e ao Executivo reclamações, queixas, ou petições, e até expor qualquer infração da Constituição, requerendo perante a competente autoridade a efetiva responsabilidade dos infratores." 43

Foi, porém, na Inglaterra - país que não formalizou uma constituição como os demais países ocidentais - que o direito de petição mostrou toda a potencialidade que poderia adquirir sob um regime representativo. Lá se estabelecera uma tradição peticionária sui generis desde os acontecimentos políticos que opuseram o rei e o parlamento no século XVII; a partir de então, as petições na Inglaterra deixaram paulatinamente de ser um instrumento de súplica ao monarca e passaram a buscar definir quais medidas seriam úteis ao governo do país. Já em 1628, a famosa Petition of Rights, dirigida ao monarca pelos parlamentares, buscava assegurar alguns direitos invioláveis aos súditos da Coroa britânica. Depois de 1642 este tipo de petição se tornou dominante e o parlamento - agora mais poderoso - deixou de enviar pedidos ao rei e passou a receber diretamente petições vindas da sociedade governada. Ao desafiar o poder monárquico a partir de uma revolução em nome do povo da Inglaterra, os Comuns se tornaram irremediavelmente o alvo prioritário das petições compostas por grupos organizados de cidadãos. ${ }^{44}$

As petições inglesas tomaram, durante os séculos XVII e XVIII, caráter eminentemente reivindicatório. O número de signatários deixou de ser uma dúzia de eminências locais para ultrapassar a barreira das centenas e até dos milhares. Conforme explica o historiador Edmund S. Morgan, "the larger the number of signatures on a petition and the larger the number of presenters, the larger the claims that could be made for it as the voice of the people - and the more embarrassing it became for the people's representatives to reject it." ${ }^{, 45}$ Os parlamentares, que durante a Revolução haviam lutado em nome da soberania popular, se tornavam cada vez mais precavidos em relação às petições: "petitioners were in a sense rivals of representatives, claiming to speak the voice of the people but unrestricted by qualifications placed on voting and uninhibited

\footnotetext{
${ }^{43}$ Constituição Política do Império do Brasil de 25 de março de 1824. Disponível no endereço eletrônico: http://www.planalto.gov.br/ccivil 03/constituicao/constituiçao24.htm. Acessado em 08 de setembro de 2009.

${ }^{44}$ Edmund S. Morgan. Inventing the People. The rise of popular sovereignty in England and America. Nova York: W. W. Norton \& Company, 1989. pp. 223-225.

${ }^{45}$ Idem. Ibidem. p. 225.
} 
by responsibilities of being part of the government. Petitions were a little too literally the voice of the people." 46 As tentativas de inibir os peticionários se mostraram vãs. Quando parte da população do condado de Kent, em 1701, enviou ao parlamento uma petição rogando aos legisladores que aprovassem os fundos que o rei pedia, o escândalo foi inevitável. A maioria dos Comuns, que durante boa parte do século XVII usara as petições como instrumento para pressionar o poder real, via o feitiço tornar contra o feiticeiro. Os parlamentares passaram, a partir de eventos como este, a clamar plena potestas; não obstante, suas conquistas políticas se baseavam sobre o ideal de soberania popular e, sem ouvir as vozes da nação, seu papel no governo inglês poderia ser novamente ameaçado.

A segunda grande transformação na atividade peticionária britânica se deu no final do XVIII, quando o regime representativo já se estabelecia de forma definitiva. Até então, as organizações reivindicatórias, por mais veementes que fossem, se voltavam majoritariamente a questões imediatas, organizando-se de maneira esporádica, sem perfazer uma mobilização de longo prazo voltada a um tema de interesse nacional. Entre 1783, quando alguns quakers enviaram ao parlamento a primeira petição que contestava a moralidade da escravidão, e 1833, quando finalmente o parlamento baniu sob aclamação popular - a escravidão dos territórios coloniais britânicos, os abolicionistas deram um novo sentido à atividade peticionária na Grã-Bretanha.

As origens do movimento abolicionista anglo-saxão estiveram ligadas a uma mudança de atitude de seitas protestantes radicais que, desde meados do século XVIII, deixaram de lado práticas de quietismo espiritual e auto-alienação para adotar uma postura mais ativa, voltada para a resolução de questões terrenas. Tanto na Inglaterra quanto nos Estados Unidos, os quakers se devotaram à luta contra os vícios humanos: jogatina, luxúria, alcoolismo, preguiça e outras tentações se transformaram no alvo preferencial do moralismo evangélico do fim dos setecentos. Mais grave do que tais vícios, na visão dos quakers, o escravismo se constituía como um injustificável desvio da moral cristã: "religious rebirth" - explica o historiador David Brion Davis "required, along with other renunciations, the voluntary manumission of slaves - a purification ritual analogous to baptism, circumcision, or dietary prohibitions that at once severed true believers from a former life of corruption and marked them off from

\footnotetext{
${ }^{46}$ Idem. Ibidem. p. 226.
} 
unregenerate Gentiles." ${ }^{47}$ A riqueza proveniente da exploração do trabalho escravo se constituía numa riqueza imoral; somente a abolição do cativeiro poderia purificar a pátria. Para o movimento evangélico que se fortalecia principalmente na Grã-Bretanha, não bastava mais esperar que os séculos fizessem da escravidão no Novo Mundo o que fizera da servidão na Europa ocidental; era preciso agir para livrar sua nação daquele gravíssimo pecado. Sem poder convencer diretamente os fazendeiros do próspero caribe britânico, os inimigos da escravidão apelaram para os representantes da nação.

O grande feito do movimento abolicionista não esteve no campo da moral. Ainda que por toda sua existência o abolicionismo britânico tenha sido liderado por evangélicos radicais como William Wilberforce, seu apelo a grupos mais amplos da sociedade foi fundamental para seu sucesso político. A primeira petição abolicionista, apesar de ter sido tomada por muitos como um simpático esforço humanitário, foi considerada pelo parlamento britânico apenas como a expressão de uma seita religiosa, sendo, por isso, completamente ignorada. Logo, os próprios quakers compreenderam que a repercussão do ideário antiescravista dependia do cosmopolitismo e não do sectarismo de sua proposta: segundo o historiador Seymour Drescher, "it was, after all, the quakers' own sense of their failure to obtain any parliamentary leverage that made them merge into a non-denominational successor organization and to begin the search for at least one committed member of parliament." ${ }^{, 48}$ Ao elaborar um discurso que tratava da escravidão como um problema nacional - e não mais apenas como um pecado condenado pelas suas crenças religiosas - os abolicionistas atraíram para sua causa grupos sociais descontentes de toda a Grã-Bretanha, grupos que de outra forma não teriam força para se expressar frente às autoridades. No mesmo movimento, conquistaram aliados dentre os representantes da nação, sobretudo dentre aqueles que tinham propostas de reforma para as instituições nacionais. Conforme explica Davis, "the cause enlisted a considerable amount of diffuse anti-establishment feeling from people who were primarily dedicated to religious liberty and parliamentary reform." 49

A primeira "mass petition" abolicionista, datada de 1787, reuniu cerca de 10.700 assinaturas de habitantes de Manchester e, nos anos subseqüentes, tal marca foi quebrada por diversas outras cidades onde a causa ganhou expressão. No auge da

\footnotetext{
${ }^{47}$ David Brion Davis. Slavery and Human Progress. Nova York/Oxford: Oxford University Press, 1986. p. 136.

48 Seymour Drescher. "Public opinion and parliament in the abolition of the British slave trade". Parliamentary History. Volume 26, suplemento. 2007. p. 45.

${ }^{49}$ David Brion Davis. Op. Cit. p. 138.
} 
campanha, entre 1830 e 1833, mais de 4.000 petições foram enviadas ao parlamento. Segundo os cálculos de Drescher, entre 1814 e 1833, mais de $20 \%$ dos ingleses adultos assinaram pelo menos uma petição combatendo o escravismo. ${ }^{50}$ Ao se transformar numa ampla discussão acerca da ordem político-social britânica, o abolicionismo foi capaz de reunir grande contingente de adeptos sob sua causa: operários, mulheres, marinheiros, irlandeses e outros setores politicamente oprimidos da Grã-Bretanha se uniram aos quakers para demandar o fim da escravidão; parlamentares radicais também seguiram a onda antiescravista. Um dos primeiros membros do parlamento a abraçar o abolicionismo foi Charles James Fox, crítico contumaz do rei George III e entusiasta das revoluções americana e francesa. Diante das "mass petitions" que se acumulavam na Casa dos Comuns, Fox questionava seus pares: "what did this prove but that individuals of all sorts, conditions and ages, young and old, master and scholar, high and low, rich and poor, the risen and the rising generation, had unanimously set every nerve on stretch for the overthrow of the (...) abominable and the indefensible?"51

Não foram poucos observadores que atentaram para a força que simples ferramentas como as petições podiam adquirir quando enviadas com insistência, em número maciço e contendo milhares de assinaturas - nas palavras de Drescher: "foreigners noted with awe that a British MP could cover the floor of the Commons with these petitions, boasting with the assurance of an Inca ruler that he would fill the whole chamber the next time around if Parliament did not act on those before it." ${ }^{, 52}$ Com o passar dos anos e a cada vez maior popularidade da causa, tanto dentro quanto fora do parlamento, os abolicionistas conseguiram que medidas antiescravistas fossem postas em discussão e em determinados momentos fossem apoiadas pela maioria dos legisladores. Assim foi possível, pois os peticionários não visaram impor aos representantes da nação sua vontade particular, não quiseram que os membros do parlamento obedecessem cegamente às suas ordens; enviaram as petições com a finalidade de informá-los que o povo britânico de um modo geral havia se antipatizado com a existência da abominável instituição nos territórios sob domínio da Coroa e desejava sua extinção.

O abolicionismo britânico, por meio de sua incansável luta, consagrou uma máxima que, aparentemente, contradizia os ideais daqueles que defendiam a

\footnotetext{
${ }^{50}$ Seymour Drescher. "Public opinion and the destruction of British colonial slavery" In: Idem (org.). From Slavery to Freedom: comparative studies in the rise and fall of atlantic slavery. Nova York: New York University Press, 1999. p. 63.

${ }^{51}$ Charles James Fox apud Seymour Drescher. "Public opinion and parliament in the abolition of the British slave trade". Op. Cit. p. 56.

${ }^{52}$ Seymour Drescher. "Public opinion and the destruction of British colonial slavery". Op. Cit. pp. 80-81.
} 
independência dos mandatos parlamentares: "accounts of the abolitionist campaigns" relata Drescher - "almost always conveyed the impression that, in gathering and signing, the public was playing a unique role in precipitating changes in parliamentary opinion and in the legislative process. (...) Abolitionists invoked symbolism linking divine and popular inspiration: 'for the vox populi erit vox Dei, the voice of a united people shall be as the voice of God', declared the Sheffield Iris. 'What arguments could be urged for staying execution upon the sentence... by the vox populi vox Dei... that slavery shall be no more', asked the Manchester and Salford Advertiser."53 O que ocorreu na Grã-Bretanha sob influência da opinião abolicionista, diferentemente do que se pode concluir de forma apressada, esteve estritamente de acordo com os princípios do regime representativo. O parlamento, quando respondeu aos clamores do movimento popular, não o fez como um delegado de um interesse particular e nem como um servo das paixões populares. Os inimigos da escravidão tiveram a capacidade de transfigurar sua demanda num assunto concernente a toda a nação britânica: aproveitando-se de um contexto de mudança social, os peticionários abolicionistas conseguiram dar sustentação política à sua causa na medida em que convenceram os legisladores de que o fim do regime escravista dizia respeito à felicidade geral dos súditos da Coroa. A emancipação dos cativos do Império britânico não foi conduzida em nome do moralismo de uma seita religiosa, mas sim como um aprimoramento da realidade nacional.

Manifestações políticas populares, como a dos abolicionistas britânicos, sempre foram condizentes com a lógica do regime representativo. A cientista política Hannah Pitkin explica que, mesmo que os representantes sejam independentes para agir em nome da nação, a constante manifestação dos cidadãos governados é essencial para o bom funcionamento da representação política: "the represented must himself be capable of action, have a will and judgement of his own; otherwise the idea of representation as substantive activity is not applicable. Taking care of someone or something helpless or totally incompetent is not representing." ${ }^{, 54}$ Representação política nunca foi sinônimo de tutela: a elite governante deve sim legislar de forma independente, mas não controlar ou submeter as expectativas da sociedade governada.

Representação pressupõe - e já pressupunha na virada do XVIII para o XIX que o representado possa formular e expressar suas demandas políticas livremente. Como coloca Bernard Manin, “dès la fin du XVIIIe siècle, la représentation est allée de

\footnotetext{
${ }^{53}$ Idem. Ibidem. p. 66.

${ }^{54}$ Hannah F. Pitkin. Op. Cit. p. 154.
} 
pair avec la consécration du droit des gouvernés à former et à exprimer à tout moment leurs opinions politiques en dehors du contrôle des gouvernants." ${ }^{.55}$ Para que o representante delibere em nome da nação, ele tem de estar informado sobre o que pensam os cidadãos. "Before it has reason to act or to deliberate," - explica Pitkin "Parliament needs to know that something is wrong, and what. The rational deliberations on interest are not conducted in a vacuum; they require data on which to work. These data are the feelings, the needs, the symptoms of the people." petições, sobretudo durante os séculos XVIII e XIX, serviram como portadoras dos sentimentos, necessidades e sintomas pertinentes aos governados: elas possibilitaram um diálogo entre representantes e representados.

Ao assegurar a liberdade de consciência, reunião e expressão aos governados, o regime representativo deixou uma porta aberta para que mostrassem aos governantes quais as expectativas do povo soberano. Segundo Manin, "les représentants ne sont pas tenus de mettre en ouvre la volonté du peuple, mais il ne peuvent l'ignorer: la liberté de l'opinion garantit que, si une telle volonté existe, elle est portée à leur connaissance. Cette volonté constitue ainsi une des données de l'environnement dans lequel les représentants ont à décider." ${ }^{57}$ Aos representantes cabia representar a nação; caso ignorassem ou se opusessem constantemente a uma opinião socialmente relevante, estariam deixando de cumprir sua missão. "A representative government" - afirma Pitkin - "requires that there be machinery for the expression of the wishes of the represented, and that the government respond to these wishes unless there are good reasons to the contrary." ${ }^{58} \mathrm{O}$ direito de petição - assim como todos os demais meios de expressão política dos cidadãos - se constituiu numa contrapartida à irrestrita liberdade dos representantes de decidir o que seria o interesse nacional: ele dava voz à população governada e fazia com que o legislador respondesse - ainda que não obedecesse - às demandas da sociedade.

O diálogo que o regime representativo permitiu entre governantes e governados foi, entretanto, submetido a regras específicas. Segundo Charles Tilly, ao final do século XVIII, "negotiation with national authorities reshaped meetings, marches, petitions, election campaigns, and other innovations of the period. ${ }^{, 59}$ A consolidação dos Estados

\footnotetext{
${ }^{55}$ Bernard Manin. Op. Cit. p. 214.

${ }^{56}$ Hannah F. Pitkin. Op. Cit. p. 188.

${ }^{57}$ Bernard Manin. Op. Cit. p. 218.

${ }^{58}$ Hannah F. Pitkin. Op. Cit. p. 232.

${ }^{59}$ Charles Tilly. Op. Cit. p. 191.
} 
Nacionais no Ocidente foi responsável, na perspectiva deste sociólogo, pela nacionalização das demandas políticas da sociedade governada. Os representantes eram autoridades nacionais com funções vitais dentro dos Estados que se consolidavam; com o objetivo de influenciá-los, as manifestações populares tiveram de se readequar: no caso do abolicionismo britânico, conforme já ficou demonstrado, houve o abandono de posicionamentos sectários e a adoção de um discurso que tratava da realidade social de forma ampla; somente assim a opinião abolicionista pôde influenciar o debate parlamentar acerca da construção (ou, nesse caso, da abolição) de instituições nacionais.

Diante da inserção das manifestações populares no quadro estabelecido pelo regime representativo, o interesse nacional passou a ser definido a partir de um processo que envolvia representantes e representados. Quando o interesse de um grupo social deixava de ser apenas um interesse restrito e se mostrava como algo relevante para a organização do país como um todo, os representantes da nação não poderiam deixar de considerá-lo, ainda que não fossem obrigados a abraçá-lo irrestrita e imediatamente. $\mathrm{O}$ permanente diálogo entre governantes e governados deu vida a uma realidade política que transcendia a luta entre interesses idiossincráticos e possibilitava o debate público com vistas na organização nacional; ou seja, o regime representativo não aboliu os diversos interesses presentes na sociedade, mas proveu-lhes de parâmetros para a negociação. O regime representativo deu aos diversos agrupamentos sociais a possibilidade de uma disputa regularizada pela definição da vontade geral. Tanto dentro quanto fora da esfera parlamentar, a atividade política se voltou para a estabilização do Estado Nacional. Mesmo os grupos dissidentes aderiram à lógica do regime na medida em que passaram a justificar suas propostas de mudança por meio do argumento do engrandecimento e da prosperidade da nação.

Burke, Madison e Sieyès negaram veementemente a obrigatoriedade dos representantes obedecerem à multidão, portadora - segundo seu ponto de vista - de interesses apaixonados e imediatistas; mais especificamente, eles se opuseram à vinculação direta entre as vontades dos cidadãos comuns e a ação dos legisladores. Não fecharam as portas, entretanto, às vozes da nação no processo de definição da vontade geral. Nenhum deles foi favorável à supressão ou mesmo à restrição da liberdade de expressão política dos governados. Conquanto a decisão última coubesse aos notáveis representantes reunidos numa assembléia nacional, nada impedia os cidadãos de se expressarem, pelos meios previstos na lei, sobre o que acreditavam ser o bem geral. Somente por meio desta expressão, os parlamentares estariam aptos a conhecer as 
necessidades dos governados e a elaborarem aquilo que se denominava interesse nacional.

No ano de 1859 o inglês John Stuart Mill elaborou uma teoria do regime representativo na qual ficava explícito que a atividade dos representantes da nação deveria ser responsiva às vozes da sociedade. Dizia ele que o parlamento nacional seria um local

where the opinion which prevails in the nation makes itself manifest as prevailing, and marshals its hosts in the presence of the government, which is thus enabled and compelled to give way to it on the mere manifestation, without the actual employment, of its strength; where statesmen can assure themselves, far more certainly than by any other signs, what elements of opinion and power are growing, and what declining, and are enabled to shape their measures with some regard not solely to present exigencies, but to tendencies in progress. ${ }^{60}$

Para o teórico britânico, a forma representativa de governo deveria conviver harmoniosamente com a livre expressão dos governados. Mill continuava a afirmar a independência do legislador frente às paixões populares; contudo, em 1859, os receios que haviam tomado estadistas e teóricos do fim do XVIII ficavam para trás e os representantes lidavam com manifestações cada vez mais constantes e regulares da sociedade governada. Os representantes da nação já haviam se firmado como os únicos agentes diretamente incumbidos de dar a palavra final acerca das leis e das instituições nacionais. Os representados, por sua vez, já haviam compreendido que o parlamento funcionava em âmbito nacional e que, caso quisessem ser ouvidos por ele, deveriam convencer que suas demandas diziam respeito à felicidade geral. A tendência, deixava claro a análise de John Stuart Mill, era que governantes e governados dialogassem cada vez com mais freqüência e maior intensidade. No entanto, este diálogo obrigatoriamente se dava sob as regras do regime representativo: para que conseguissem abrir a porta das legislaturas nacionais, os diversos interesses da sociedade tinham que tratar de questões concernentes à pátria como um todo. Nada lhes garantia que suas demandas seriam atendidas, contudo podia-se ter cada vez maior certeza de que os ilustres representantes da nação responderiam aos cidadãos comuns.

Uma sociedade dinâmica e capaz de se mobilizar politicamente em nível nacional, como eram as sociedades de alguns países do Ocidente da virada do século XVIII para o XIX, exigia uma forma de governo capaz de absorver múltiplos interesses

\footnotetext{
60 John Stuart Mill. Essays on Politics and Society. Considerations on Representative Government. Toronto/Buffalo: University of Toronto Press, 1977. p. 432.
} 
sem, contudo, causar conflitos facciosos que colocassem em risco seu próprio desenvolvimento. O regime representativo - e as regras que estabeleceu - foi essencial para o cumprimento deste fim, pois permitiu a participação regulada de setores importantes da sociedade na política nacional. Thomas Paine, já em 1792, expressara um ideal caro aos pensadores de seu tempo pelas seguintes palavras: "a nation (...) is like a body contained within a circle, having a common centre, in which every radius meets; and that centre is formed by representation." 61 A partir do diálogo entre representantes e representados - diálogo que foi mediado, em muitos casos, pelas petições - este ideal foi alcançado.

${ }^{61}$ Thomas Paine. Common Sense and Other Writings. Nova York: Barnes and Nobles, 2005. p. 204. 


\section{CAPÍTULO 2. DE SÚDITOS A REPRESENTADOS: A ATIVIDADE PETICIONÁRIA NO ANTIGO REGIME PORTUGUÊS E NA MONARQUIA CONSTITUCIONAL BRASILEIRA}

No Antigo Regime, o direito de petição assumiu uma importante função política: levar ao monarca os motivos de descontentamento de seus súditos. Segundo o historiador Pedro Cardim, "a petição era uma espécie de canal de expressão de protesto, forma autorizada pela Coroa (...). O exemplo ilustrativo deste ato era o do pai que ouvia os seus filhos, uma imagem extremamente recorrente na literatura da época." ${ }^{~} 62$ A imagem de um pai benévolo e justo para com seus filhos era constantemente oposta à figura do rei tirano, inacessível e, por isso, ilegítimo. Ao levar em conta as petições, reparando injustiças perpetradas contra seus súditos ou beneficiando algum deles com uma graça, o monarca do Antigo Regime legitimava sua posição soberana perante a sociedade governada.

Durante o século XVII, a maior parte das petições recebidas pelo monarca lusitano era encaminhada através das Cortes. Quando convocados, representantes de cada um dos três estados - clero, nobreza e povo - se reuniam para discutir temas como a aclamação de um novo rei, o juramento do príncipe herdeiro, o lançamento de novos tributos, a quebra da moeda etc. Este constitucionalismo corporativo colocava, de certa forma, um limite ao arbítrio do monarca. Nessas ocasiões os corpos que formavam a sociedade politicamente ativa do Antigo Regime levavam ao soberano petições que diziam respeito a problemas que afligiam setores da população do Reino. Por meio de seu procurador, moradores de uma vila ou membros de uma corporação buscavam mostrar ao rei que sofriam algum tipo de injustiça e que esperavam remédio de suas mãos. Logo que uma carta régia levava às localidades a notícia de que as Cortes se reuniriam, seus mais importantes homens começavam a compilar uma série de situações tidas como injustas. As petições, na maioria das vezes, eram assinadas pela gente de governança, o que lhes aumentava o prestígio e lhes dava legitimidade para tratar dos assuntos de cada povoado. ${ }^{63}$

As queixas não eram feitas arbitrariamente. Uma vez compilados os problemas que cada um julgava sofrer, devia-se ponderar sobre sua gravidade, identificar o

\footnotetext{
${ }^{62}$ Pedro Cardim. "O quadro constitucional. Os grandes paradigmas de organização política: a coroa e a representação do Reino. As cortes" In: Antonio Manuel Hespanha (coord.) História de Portugal. Volume 4: O Antigo Regime (1620-1807). Lisboa: Estampa, 1998. p. 134.

${ }^{63}$ Idem. Cortes e Cultura Politica no Portugal do Antigo Regime. Lisboa: Cosmos, 1998. pp. 137-140.
} 
responsável pela sua existência e, principalmente, calcular as possibilidades da queixa ser bem acolhida pelo monarca. Exigia-se, assim, por parte dos peticionários, um conhecimento da história das Cortes e da teoria política sobre a qual estava assentada a monarquia portuguesa. Por isso, normalmente eram os mais esclarecidos homens de cada localidade, em sua maioria magistrados, que se ocupavam de quase todo o trabalho de elaborar esses documentos. O tom elevado da retórica utilizada na escrita das queixas confirmava que cabia apenas às elites locais a atividade de redigir as petições a serem encaminhadas ao soberano. Na sua retórica, além de uma cuidadosa escolha lexical, havia uma estratégia argumentativa quase universal. Os peticionários construíam um passado edulcorado, afirmando que seu mundo vivera sempre baseado na harmonia, na justiça e no equilíbrio, até o momento em que algo ou alguém chegara para perturbar a concórdia original. Elementos como uma guerra, uma tarifa abusiva ou uma autoridade descontrolada eram normalmente apontados como culpados pela desgraça comunitária. Caberia, então, ao soberano - pai defensor dos direitos e privilégios dos povos governados - tomar as providências necessárias para restabelecer a boa ordem das coisas. $^{64}$

$\mathrm{O}$ argumento central da maioria das petições levadas às Cortes no Antigo Regime era a defesa da paz e da justiça. Os privilégios locais eram defendidos como um meio de se garantir a ordem em todo o Reino. Neste sentido, os peticionários faziam questão de lembrar ao soberano que se constituíam num grupo de homens virtuosos, lembrando façanhas passadas pelas quais os moradores de sua localidade haviam contribuído para o engrandecimento de Portugal. No ano de 1645, por exemplo, os moradores de Barcelos pediram os mesmos privilégios gozados pelos cidadãos do Porto lembrando que haviam contribuído de bom grado, com muita gente e dinheiro, para a guerra da Catalunha, além de terem respondido com prontidão ao chamado de 1640 , participado da tomada do castelo de Viana e enviado mais de cinco mil homens para Galícia e Salvaterra. Os peticionários não poupavam meios para cativar o olhar régio já que toda a atividade estava baseada na ficção de que o soberano iria ler e pessoalmente responder às petições; sendo assim, os vassalos não se cansavam de lembrar-lhe que esperavam, como filhos, que o pai os acudisse nas situações de aflição que enfrentavam. ${ }^{65}$

\footnotetext{
${ }^{64}$ Idem. Ibidem. pp. 140-144.

${ }^{65}$ Idem. Ibidem. pp. 144-149.
} 
Era evidente, mesmo para os contemporâneos, que o rei não lia todas as petições já que, quando as Cortes se reuniam, facilmente o número de queixas superava a casa do milhar. Contudo, a ficção era sustentada por todas as partes envolvidas e os funcionários régios encarregados de analisar as petições o faziam em nome do próprio monarca. $\mathrm{O}$ ideal era que todas as queixas enviadas fossem respondidas: um procurador da Coroa lusitana, Tomé Pinheiro da Veiga, chegou mesmo a elaborar um método de classificação e resposta das petições em 1645. A intenção era que, depois da Restauração do trono português, a legitimidade da dinastia bragantina fosse fixada até mesmo nos mais longínquos povoados do Reino. Dada a situação de crise pela qual passava a monarquia portuguesa recém-separada de Castela, o apoio dos súditos era buscado pela otimização dos meios de resposta às suas petições. Buscava-se comprovar que D. João IV era um governante preocupado com as agruras dos governados por meio da atenção que a Coroa dispensava aos assuntos particulares. ${ }^{66}$

Além de serem fundamentais para a legitimação do poder monárquico dentro do Reino, as petições tiveram grande importância na administração das conquistas ultramarinas portuguesas. Devido à magnitude territorial das colônias e de sua distância da metrópole, os problemas administrativos se acumulavam: principalmente em relação às regiões mais afastadas, as distorções nas comunicações podiam se tornar fatais para a unidade do Império marítimo português. De acordo com Heloísa L. Belloto, “face a estas dificuldades, já não se pretendia, no século XVIII, em relação ao Brasil, uma administração única; ou seja: sim à centralização política e com base em Portugal, não à centralização administrativa." ${ }^{\circ 7}$ Desta feita, uma instituição em especial tornou-se influente nas relações entre colônia e metrópole no século XVIII: os senados das câmaras (ou câmaras municipais). Os seus membros contavam com alguns privilégios, conforme relata o historiador Charles R. Boxer: "the oficiais da camara were privileged individuals who could not be arrested arbitrarily, nor subjected to judicial torture, nor imprisoned in chains, save only in cases such as high treason (...). They were also free from military service, save only when the city was directly attacked (...). They had the privilege of corresponding directly with the reigning monarch, and they enjoyed various

\footnotetext{
${ }^{66}$ Idem. Ibidem. pp. 161-165.

${ }^{67}$ Heloísa L. Belloto. "O Estado português no Brasil: sistema administrativo e fiscal” In: Idem (coord.) Nova História da Expansão Portuguesa. Volume 8: O Império Luso-Brasileiro. 1750-1822. Lisboa: Estampa, 1986. p. 265.
} 
judicial immunities." 68 Os homens bons das colônias (ou seja, aqueles que desempenhavam cargos administrativos locais ou os tinham desempenhado em algum ponto do passado) por terem de algum modo contribuído para as conquistas do Império ultramarino - fosse pelas guerras contra invasores franceses e batavos, fosse pela ocupação dos sertões, fosse pela edificação de fortes e edifícios governamentais etc. tornavam-se portadores de direitos. ${ }^{69}$ Dentre estes direitos estava o direito de petição; mesmo com a interrupção da reunião das Cortes durante o século XVIII, as petições se tornaram instrumento indispensável para a administração das conquistas já que permitiam que fossem levadas ao centro do Império português as preocupações concernentes aos seus pontos mais remotos.

Conhecedores dos códigos que regulavam as relações de poder na monarquia lusitana, os habitantes da América comunicavam-se constantemente com o Rei com a finalidade de defender o que acreditavam ser seus direitos adquiridos. As petições remetidas pelos homens bons da colônia se transformaram logo no canal que diretamente ligava os dois lados do Atlântico. Quando chegavam a Portugal, elas eram em primeira instância avaliadas pelo Conselho Ultramarino e posteriormente seguiam à presença da Coroa que, depois de solicitar os pareceres e as informações que achava necessários, deliberava sobre as reclamações. A historiadora Maria Fernanda Bicalho demonstra como as petições do ultramar adquiriram uma função importante para o governo do Império lusitano: "nesse vaivém de reclamações e informações a Coroa podia, por meio de uma ampla visão dos diferentes argumentos e das perspectivas contrastantes, administrar sabiamente os conflitos e melhor governar a colônia., 70

Insistentes petições à metrópole foram enviadas pelas câmaras da colônia americana demandando privilégios como autogestão de negócios coloniais, isenção do serviço militar para os homens bons e seus protegidos, exclusão de reinóis das eleições para os cargos administrativos das municipalidades, vantagens na exploração de minas descobertas no continente americano etc. Não obstante a distância e a diversidade dos temas, as petições do ultramar seguiam a mesma lógica argumentativa das petições do Reino: como exemplifica Bicalho, a câmara municipal de Angra dos Reis, em 1740, reforçava um pedido feito ao rei para a obtenção de um privilégio governativo

\footnotetext{
${ }^{68}$ Charles R. Boxer. Portuguese Society in the Tropics: the municipal councils of Goa, Macao, Bahia, and Luanda, 1510-1800. Madison/Milwaukee: University of Wisconsin Press, 1965. p. 10.

${ }^{69}$ Maria Fernanda Bicalho. A Cidade e o Império: o Rio de Janeiro no século XVIII. Rio de Janeiro: Civilização Brasileira, 2003. pp. 322-332.

${ }^{70}$ Idem. Ibidem. p. 353.
} 
"argumentando que seus moradores eram incessantemente recrutados como soldados para a guarnição do Rio de Janeiro, abandonando suas famílias aos horrores da miséria e às atrocidades cometidas por inimigos e invasores. Por ocasião da invasão da cidade do Rio de Janeiro pelos franceses, os homens de Angra se deslocaram para socorrê-la, ausentando-se de suas casas por mais de um mês, "com larga despesa à sua custa'.,71

Quando requeriam algo ao monarca, os homens bons da colônia reafirmavam a obediência devida e, ao mesmo tempo, alertavam-no para a obrigatoriedade do reconhecimento de seus direitos adquiridos. ${ }^{72}$ Muitas vezes, porém, as exigências dos colonos ultrapassavam os limites aceitáveis pela etiqueta política da época - Boxer relata dois episódios em que homens bons de Salvador se excederam ao escrever suas petições ao soberano português: "the freedom with which the municipal councilors of Bahia complained to the Crown on matters of high policy provoked the attorney general at Lisbon to observe in 1678 that those worthies should be severely reprimanded for acting as if they shared with the Prince Regent, D. Pedro, the responsibility of ruling the Portuguese empire. Twenty years earlier the governor-general, Francisco Barreto, had told the camara to reword a particularly outspoken passage in one of its many representations to the Crown concerning the evils of the Brazil Company; since, he said, this bluntness did not accord 'with the humility and submission with which the kings should always be addressed." "73 Ainda que os atritos fossem freqüentes, as petições enviadas pelos senados das câmaras coloniais ao soberano português formavam um forte elo entre o reino europeu e suas distantes e gigantescas colônias. Os homens bons - instrumentos da expansão portuguesa pelo mundo - podiam, por intermédio das petições, colocar suas súplicas diretamente ao centro do governo lusitano. Este, por sua vez, mantinha-se informado das principais questões que interferiam no governo de sua conquista e reforçava constantemente o vínculo com os governados.

Apesar da grande importância que a atividade peticionária adquiriu para a legitimação do poder real durante o Antigo Regime e para a administração das conquistas ultramarinas, Pedro Cardim deixa claro que "a maioria dessas petições versava sobre questões locais, em cuja resolução os procuradores esperavam que o rei pudesse ter uma palavra a dizer, e que a autoridade interviesse - mas pontualmente,

\footnotetext{
${ }^{71}$ Idem. Ibidem. p. 388.

${ }^{72}$ Idem. Ibidem. pp. 390-392.

${ }^{73}$ Charles R. Boxer. Op. Cit. p. 85.
} 
apenas naquele caso - na vida local." ${ }^{, 74}$ A concepção política reinante era uma concepção denominada por especialistas como juridizada. O poder soberano tinha como atributo mais importante fazer justiça e defender o bem comum. A ordem costumeira deveria ser mantida a qualquer custo e o rei deveria agir como uma instância que zelasse pelas prerrogativas corporativas e corrigisse os abusos que aparecessem; como um pai que desse aos seus filhos a proteção de sua autoridade quando assim um deles requeresse. Ainda nas palavras de Cardim, na sociedade do Antigo Regime "a justiça funcionava como elemento configurador da política." ${ }^{, 75}$

O historiador António Manuel Hespanha, em As Vésperas do Leviathan, afirma que, de acordo com a teoria corporativa da sociedade e do poder no Antigo Regime, a função dominante da Coroa era garantir a Justiça - com J maiúsculo, considerada como algo superior às questões terrenas. Ao rei era dado conhecer as causas em última instância, a ele cabia a suprema iurisdictio. Uma de suas funções mais importantes era manter os direitos estabelecidos intocados: toda vez que um súdito (ou grupo de súditos) sofresse com um grave abuso, cabia ao rei ministrar o remédio e assim recolocar as coisas em seus devidos lugares. Nas palavras de Hespanha: “o seu papel não era nem o de reorganizar a sociedade, nem o de fazer progredir para formas mais perfeitas (mais 'justas', mais 'desenvolvidas', mais 'eficazes') de organização. Era o de conservar, constituindo-se apenas como árbitro dos conflitos sociais e garante dos equilíbrios estabelecidos." 76 A função da cabeça do corpo político do Antigo Regime era manter a harmonia entre os seus membros: ao rei cabia realizar a Justiça, ou seja, manter a ordem social e política inalterada. A atividade do poder superior era orientada para a resolução de conflitos pontuais, atribuindo a cada qual aquilo que lhe coubesse. ${ }^{77}$

A atividade peticionária tratada até aqui esteve, sem dúvida, inserida na lógica corporativa de poder do Antigo Regime: ela pouco tinha de propositiva, pois visava restabelecer uma ordem que, acreditavam os peticionários, havia sido alterada; ela tinha como foco o particular, tratava dos direitos de cada grupo da sociedade, sem pretender interferir em questões gerais. Assim como o poder real tinha como função central conservar os equilíbrios estabelecidos entre as partes do Reino, a atividade peticionária dos séculos XVII e XVIII que a ele se dirigia visava perpetuar a boa ordem dos assuntos

\footnotetext{
${ }_{75}^{74}$ Pedro Cardim. Cortes e Cultura Politica no Portugal do Antigo Regime. Op. Cit. p. 169.

${ }^{75}$ Idem. Ibidem. p. 187.

${ }^{76}$ António Manuel Hespanha. As Vésperas do Leviathan. Instituições e poder político, Portugal - séc. XVII. Coimbra: Almedina, 1994. pp. 488-489.

77 Ângela Barreto Xavier e António Manuel Hespanha. "A representação da sociedade e do poder" In: Antonio Manuel Hespanha (coord.) História de Portugal. Op. Cit. pp. 115-116.
} 
particulares. Os peticionários, tanto do Reino quanto das conquistas, não buscavam recriar o mundo segundo suas concepções: buscavam apenas o que em tempos imemoriais se estabelecera como bom e justo, buscavam o que lhes era próprio e de direito.

A atividade peticionária que se desenvolveu na primeira metade do século XIX no Império brasileiro esteve longe de romper completamente com as concepções vigentes durante o Antigo Regime. Muitas das concepções que pautaram a atividade peticionária no Brasil eram caudatárias do que existira em Portugal e na América Portuguesa entre os séculos XVII e XVIII. Ainda assim, a historiografia vem demonstrando que as petições foram muito importantes durante o período que sucedeu ao processo de independência. Há atualmente dois estudos que demonstram como, logo que a Assembléia Constituinte tomou assento, o Poder Legislativo se tornou, assim como nos demais países regidos pelo regime representativo, um foco de atração para a maior parte das petições produzidas pela sociedade governada. A população brasileira reconhecia que, a partir daquele momento, o parlamento do Império tornava-se uma peça central na distribuição dos poderes do Estado.

Jaime Rodrigues, a partir do estudo de um caso em que escravos urbanos peticionaram à Assembléia Constituinte contra sua senhora, ilustra a potencialidade que aquele antigo instrumento adquiriu sob uma nova era política. Os escravos peticionários já haviam buscado outros meios de litígio contra os abusos que sofriam da parte de sua senhora: foram à justiça em primeira instância e recorreram posteriormente à revisão processual. Enquanto aguardavam uma decisão do Judiciário, apelaram a um poder novo no Brasil, já naquele momento considerado por muitos como o receptáculo da soberania nacional. Na verdade, explica o historiador, o que faziam os escravos era uma aposta: "os deputados constituintes podiam atender ou não ao pedido encaminhado por Inácio Rodrigues e seus companheiros - a questão era tentar. Se a resposta fosse positiva, ganhavam os escravos que tiveram a ousadia de pedir a correção de um caso em que eles se acharam injustiçados. Se a resposta fosse negativa, a justiça continuaria a cuidar do caso como vinha fazendo até aquele momento. Os escravos de Águeda Caetana perceberam ter pouco a perder." 78

A aposta dos escravos surtiu efeito: vários deputados se ocuparam da questão durante três sessões; num momento de indefinição das atribuições de cada poder, o Legislativo se viu compelido a tratar de uma questão que não lhe competia em teoria.

${ }^{78}$ Jaime Rodrigues. "Liberdade, humanidade e propriedade: os escravos e a Assembléia Constituinte de 1823". Revista do Instituto de Estudos Brasileiros. Número 39. 1995. p. 162. Disponível no endereço eletrônico: http://www.ieb.usp.br/revista/revista039/rev039jaimerodrigues.pdf. Acessado em 02 de maio 2008 . 
Segundo explica Rodrigues, "o fato é que a Constituinte - que a rigor deveria estabelecer as diretrizes legais para o país independente - teve suas crises de competência."79 Os poderes do Estado, por mais que a teoria política da época assim estabelecesse, não tinham ainda suas esferas de atuação rigorosamente separadas. Por mais que fosse claro que o Legislativo devesse elaborar leis e o Judiciário julgar em conformidade a elas, nada impedia o deputado Teixeira Gouveia, por exemplo, de propor que a Assembléia pedisse o processo judiciário referente aos escravos de Águeda Caetana para examinar possíveis irregularidades no seu transcorrer e solicitar revisão se necessário.

A indefinição das competências de cada poder não se resolveu com a Constituição de 1824. Conforme mostra o historiador Vantuil Pereira, durante todo o Primeiro Reinado o que prevaleceu foram petições à Câmara dos Deputados que, ao fim e ao cabo, buscavam corrigir injustiças. Segundo ele, aquele era um período de crise política, de disputas no seio do Estado pela definição de qual poder teria supremacia sobre os demais, no qual os cidadãos acabaram por enxergar no parlamento uma instância capaz de atender às suas súplicas: "pressionava-se para que algumas alternativas se afirmassem em relação aos direitos e contra abusos do que se considerava injusto e opressor." ${ }^{, 80} \mathrm{O}$ direito de petição, garantido pela recém-criada Constituição monárquica, tornava-se um meio de se encaminhar ao seio da representação nacional queixas contra injustiças que sofriam os cidadãos do Império. $\mathrm{O}$ historiador deixa claro que as petições do Primeiro Reinado tinham pouca relação com reivindicações políticas gerais: "as petições à Assembléia brasileira limitaram-se quase que exclusivamente aos problemas individuais. Situavam-se mais no campo das queixas e das reclamações. Isso vem demonstrar que o parlamento ocupava um vazio institucional em relação à justiça ou tornava-se um adequado instrumento para politizar o que outrora foi considerado abuso das autoridades." ${ }^{\text {} 81}$

Alguns exemplos utilizados por Pereira em seu artigo ilustram o referido caráter de súplica das petições do Primeiro Reinado: diversos presos diziam-se injustamente detidos, sem terem sido julgados e condenados pelas autoridades competentes; proprietários de secos e molhados do Recife mostravam-se cansados de serem aliciados pelo guarda-mor da saúde; Bernardino de Moura pedia reparo e proteção face ao que

\footnotetext{
${ }^{79}$ Idem. Ibidem. p. 163.

${ }^{80}$ Vantuil Pereira. "Petições: liberdades civis e políticas na consolidação dos direitos do cidadão no Império do Brasil (1822-1831)" In: Gladys Sabina Ribeiro (org.). Brasileiros e Cidadãos: modernidade política, 1822-1930. São Paulo: Alameda, 2008. p. 102.

${ }^{81}$ Idem. Ibidem. p. 107.
} 
considerava um arbítrio do Tribunal Conselho de Marinha; empregados da câmara de Sabará reclamavam da pesada força do despotismo pela qual sofriam; José Barros Bernardes acusava uma autoridade de praticar o "antigo despotismo"; Maria Araújo, viúva de Constantino Ribeiro, reclamava que a partir da morte do marido entrara em conflito com Domingos Gonçalves Moreira o qual acreditava ter direito à herança do falecido; etc. ${ }^{82}$ Estes exemplos evidenciam que, aproveitando-se das oportunidades abertas num tempo em que a divisão dos poderes do Estado era ainda pouco clara, os cidadãos do Primeiro Reinado se utilizavam das petições prioritariamente para requerer justiça ao "Soberano Congresso". Segundo Pereira, "o movimento peticionário caracterizou-se pela crença dos cidadãos de que eram possuidores de direito e que, pela utilização daquele mecanismo, poderiam garantir as suas reivindicações." 83 Estes direitos, no entanto, diziam respeito apenas a garantias particulares.

Ambos os trabalhos citados tratam de um período em que a atividade peticionária apenas começava a se inserir na lógica do regime representativo brasileiro. Entretanto, os textos de Rodrigues e Pereira indicam uma mudança importante na vida institucional brasileira: os peticionários, a partir do estabelecimento da monarquia constitucional, deixaram de ser apenas autoridades locais e homens privilegiados, como acontecia no Antigo Regime, e passaram a incluir até mesmo escravos, presos e viúvas. Também o alvo prioritário das petições se alterou: o rei, pai misericordioso no Antigo Regime, perdeu muito de seu apelo quando, sob o regime constitucional, os representantes eleitos da nação tomaram a si uma significativa parte das funções do soberano. A ruptura histórica apontada pelos textos acima citados se constitui num valioso achado para a historiografia brasileira, pois indica que, com a Independência e a Constituição, a gama de atores políticos no Brasil se expandiu de modo inconcebível durante o Antigo Regime e os representantes eleitos da nação foram reconhecidos como figuras centrais da ordem política vigente.

Não obstante as mudanças, uma significativa continuidade em relação à atividade peticionária do Antigo Regime ainda permanecia no Primeiro Reinado: assim como em Portugal e em suas colônias dos séculos XVII e XVIII, as petições das primeiras décadas do Império preservavam a idéia de que o papel do soberano era garantir a justiça aos governados que a ele acorriam no que dizia respeito a questões particulares. Não havia ainda no Brasil a participação no debate público acerca das

\footnotetext{
${ }^{82}$ Idem. Ibidem. pp. 108-122.

${ }^{83}$ Idem. Ibidem. p. 127.
} 
instituições nacionais que as petições foram capazes de promover quando os regimes representativos se estabeleceram em alguns países do mundo ocidental. O grupo de peticionários se expandiu drasticamente após a Independência e o alvo principal de suas demandas mudou; todavia, o modo de usar as petições não sofreu mudança significativa.

Dentre as centenas de petições referentes aos primeiros anos do Segundo Reinado que pude consultar no Arquivo da Câmara dos Deputados, boa parte manteve as características das petições do Primeiro Reinado. Eram basicamente requerimentos aos representantes da nação pela correção de uma injustiça sofrida por um grupo ou por um indivíduo. Havia dentre estas petições todo tipo de demanda e todo tipo de emissário: viúvas requeriam pagamentos devidos aos seus falecidos maridos, os quais, na maioria dos casos, haviam lutado pela causa pátria; grande quantidade de funcionários públicos rogava por aumento de salários tendo por justificativa os elevados custos de vida que sua profissão lhes impunha ou a graça obtida por outros na mesma condição; irmandades religiosas e santas casas de misericórdia pediam auxílio para construção ou reforma de um templo ou hospital, o qual livraria os habitantes de uma localidade dos sofrimentos que padeciam; fazendeiros, empresários ou elites políticas locais pediam isenção de impostos opressivos, explicando que sua manutenção causaria a ruína a uma determinada região; etc. $\mathrm{O}$ que não variava, no entanto, era o caráter destas petições: elas suplicavam ao poder soberano, assim como ocorrera no Antigo Regime português e no Primeiro Reinado, para que fosse garantido o que fosse bom e justo para cada qual. Apesar desta evidente continuidade, parte da atividade peticionária no Brasil - como doravante pretendo mostrar - mudava conforme a ordem monárquica constitucional se estabilizava. A mudança não foi nem imediata e nem universal, contudo ela foi de grande relevância para o processo de construção das instituições nacionais brasileiras.

Um grupo de petições mais reduzido do que as suplicatórias, porém não menos importante, se destacou nas primeiras décadas do Segundo Reinado. Elas não visavam corrigir uma injustiça cometida contra um particular e nem suplicavam por um direito de determinado povoado, mas buscavam influenciar na discussão de assuntos nacionais, normalmente assuntos políticos candentes de seu tempo: procuravam, dentro daquilo que lhes cabia, participar do aprimoramento das leis e instituições do Império. Estas petições estavam inseridas no debate público sobre temas centrais na construção de uma 
ordem monárquica constitucional e representativa, tinham por objetivo colaborar na ordenação da vida política do país como um todo.

O caso do doutor Antonio Gomes parece ser, pelo seu caráter audacioso, um dos mais ilustrativos desse novo tipo de petição que surgia no Brasil do início do Segundo Reinado. Escrevia ele, no ano de 1845, à Câmara dos Deputados:

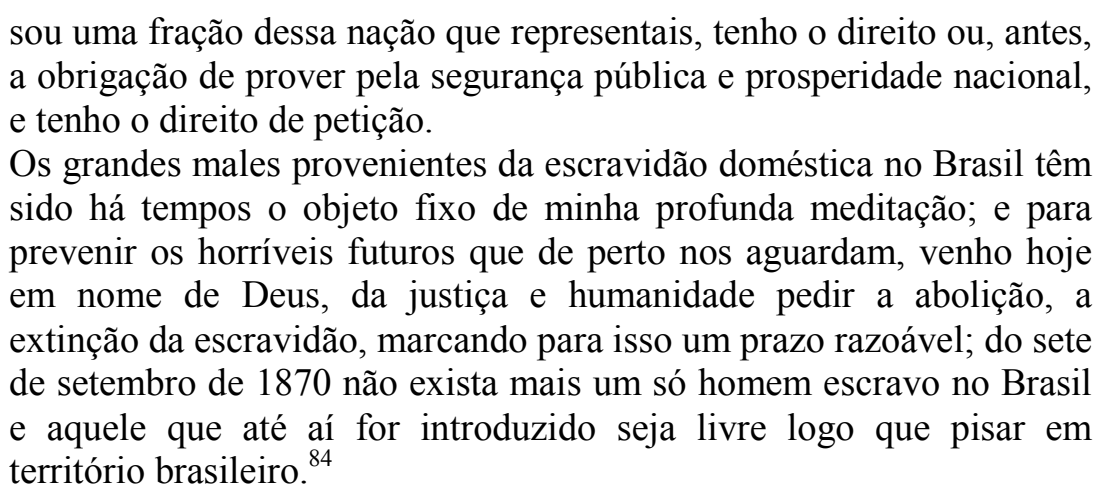

A preocupação do médico com o problema da escravidão era apresentada aos representantes da nação: conhecedor de seu direito e do caráter do regime que regia o Império, Antonio Gomes se utilizava da petição para sugerir que os deputados legislassem a favor da emancipação. Evidentemente, o tom utópico da proposta se constituía numa exceção. Prevaleceram petições mais pragmáticas, que se conformavam às possibilidades do contexto político e social em que estavam inseridas. Porém, o caso do doutor Gomes demonstra como praticamente qualquer tipo de demanda política podia ser levantada pelos cidadãos brasileiros diante de seus representantes, contanto que dissessem respeito ao interesse nacional. Aos cidadãos não cabia apenas lutar pelo que fosse justo para si ou para aqueles que estavam próximos; ainda que assim continuassem a fazer em muitos casos, os brasileiros paulatinamente compreendiam que sob o regime representativo lhes cabia participar da definição da vontade geral. Sendo assim, sua atividade peticionária se nacionalizava.

O polêmico tema da escravidão foi recorrente nas petições enviadas à Câmara dos Deputados no início do Segundo Reinado. A Lei de 07 de novembro de 1831, a qual, sem sucesso, visou abolir o tráfico negreiro para o Brasil, sofreu contestações de algumas câmaras municipais das províncias do Rio de Janeiro, São Paulo e Minas Gerais. Em 1840, por exemplo, os vereadores da vila de Arêas, incomodados com a impossibilidade das autoridades do governo central fazerem cumprir a referida lei,

\footnotetext{
${ }^{84}$ Petição do doutor Antonio Gomes. 22 de janeiro de 1845. Centro de Documentação e Informação. Arquivo da Câmara dos Deputados. Brasília. Consultado em fevereiro de 2009.
} 
pediam sua revogação dizendo que, por mais elevados que tivessem sido os sentimentos do legislador ao aprovar a medida,

é forçoso reconhecer que a legislatura que a votou não atendeu bem às circunstâncias especiais em que se achava e ainda agora se acha a nação, que não considerou que, se a lei fosse executada, produziria um repentino definhamento no nosso único ramo de indústria, a produção agrária.

(...) A Lei de 7 de novembro de 1831 encontrou, desde a sua publicação, uma resistência geral pela opinião que dominava não só de sua inconveniência e fatalíssimos resultados, mas também de ser ela um corolário de um ato diplomático (o tratado para a abolição da escravatura), estipulado pelas sugestões de um governo estrangeiro que, sob o pretexto de defender os direitos da humanidade, ocultava a intenção e o único fim de aniquilar a nossa agricultura, desviando-lhe os braços, para favorecer os seus produtos coloniais nos grandes mercados dos dois hemisférios. $O$ resultado desta resistência foi o não se executar a lei em parte alguma, tornarem-se não só os mais graves cidadãos, mas até as autoridades, cúmplices do seu desprezo; enfim, de ou dever ser a nação inteira processada ou de ficar a lei ludibriada e letra morta. ${ }^{85}$

Não aprovada pelos fazendeiros e autoridades locais do Império, a Lei de 07 de novembro se mostrava apenas como uma imposição estrangeira sobre o interesse da nação brasileira e, por isso, segundo algumas câmaras municipais, deveria ser revogada. Tomando partido oposto ao do médico supracitado, os vereadores lutavam contra uma lei que feria diretamente os proprietários de escravos. No entanto, inseriam a causa escravocrata no debate acerca da realidade política do Brasil como um todo: ao demandarem uma medida legislativa contra "a intenção e o único fim de aniquilar a nossa agricultura", não tratavam apenas do destino dos fazendeiros, mas olhavam para o Império como um todo e para os prejuízos que o país teria caso a lavoura fosse prejudicada. A câmara de Arêas não abandonava a elite econômica local, contudo defendia seus interesses como algo fundamental para a riqueza nacional.

Dez anos depois das manifestações a favor do tráfico de escravos, a câmara municipal da capital da Bahia deplorava o "infame comércio" por meio de uma petição. No ano de 1850 o projeto defendido por Eusébio de Queiroz estava sendo discutido no parlamento e os vereadores baianos aproveitavam a oportunidade para demonstrar seu descontentamento em relação à degradação que o tráfico negreiro trazia àquela importante cidade do Império.

Ser indiferente a esse montão de combustíveis que se acumulam contra a sociedade brasileira, expondo-nos aos contínuos sustos de

\footnotetext{
${ }^{85}$ Petição da câmara municipal da vila de Arêas. 18 de maio de 1840. Centro de Documentação e Informação. Arquivo da Câmara dos Deputados. Brasília. Consultado em fevereiro de 2009.
} 
bárbaras insurreições, não o pode ninguém que seriamente pense no futuro do país, não o pode aquele em cujas veias corre o sangue de livres, ou cuja inteligência conheça os desígnios da religião de Jesus Cristo; nem portanto deve a câmara municipal da cidade da Bahia.

Expor-vos, Augustos e Digníssimos Senhores Representantes da Nação, toda hediondez do tráfico de escravatura africana; lembrar-vos que o porvir da sociedade brasileira está dependendo do acabamento desse fato imoral; ponderar-vos que a felicidade da Nação exige a terminação dum comércio desumano, anti-político, anti-nacional e matador de nossa indústria e de nossa moralização, como outrora o havia sentido e escrito o nosso sábio patrício o Visconde de Cairu; dizer-vos que a introdução de africanos nos traz o regresso em civilização, a imoralidade e o crime, fora duvidar do vosso patriotismo e de vossas luzes. ${ }^{86}$

As petições da câmara de Arêas e da câmara de Salvador estavam inseridas em contextos políticos opostos no que dizia respeito ao tráfico. Porém, tanto uma como a outra refletiam o clima do debate público de sua época, aproveitando-se das oportunidades políticas que se abriam para fazerem suas demandas. $\mathrm{O}$ importante a se ressaltar aqui é que ambas visavam interferir em questões vitais para toda a sociedade brasileira: os vereadores baianos não viam o tráfico como um mal apenas para a cidade de Salvador, mas argumentavam que do seu fim dependia "o porvir da sociedade brasileira" e "a felicidade da Nação".

A transformação da atividade peticionária a partir das primeiras décadas do Segundo Reinado foi tão significativa que, mesmo no caso de petições que buscavam da Câmara favores específicos a sujeitos particulares, o discurso que legitimava as súplicas era baseado no ideal do interesse nacional. O exemplo das demandas da nascente manufatura brasileira é ilustrativo deste novo modelo de petição que se fixava no Brasil. Antonio Rodrigues Rino, por exemplo, em 1840 suplicava à Câmara um auxílio para montar e fazer trabalhar uma máquina onde prepararia uma série de substâncias químicas. Segundo ele, a eficiência de sua invenção não podia ser contestada e, além do mais, atendia a fins elevados:

uma grande necessidade do país é encorajar a indústria, sustentar e coadjuvar as empresas nascentes, trabalhar em prol dos progressos materiais, que tanto exige o Brasil para seu engrandecimento, o painel que se desenvolver no futuro será bastantemente esperançoso.

Augustos e Digníssimos Senhores, o suplicante inventa uma máquina que simplificando o processo dessas substâncias, tão necessárias ao uso da vida e das exigências da civilização moderna, prepara ao Brasil um meio de se livrar da indústria estrangeira que, na ausência de uma nacional, dita leis tirânicas ao país e lhe fecha a carreira de um futuro,

\footnotetext{
${ }^{86}$ Petição da câmara municipal da cidade da Bahia. 23 de julho de 1850. Centro de Documentação e Informação. Arquivo da Câmara dos Deputados. Brasília. Consultado em fevereiro de 2009.
} 
qual deve anelar esta terra heróica de Santa Cruz. Cumpre ajudar o espírito que se desenvolve de indústria nacional, cumpre que todos façamos à pátria os sacrifícios de nossas forças, na proporção de cada um. Uma máquina destas promete, afiança, hipoteca grandes e vantajosos resultados à indústria brasileira; - ao suplicante cabe a glória de inventá-la e a vós, vos toca a de estabelecê-la, firmá-la, realizá-la; concedendo-lhe o auxílio que ele vos pede. ${ }^{87}$

Rino pedia aos representantes da nação a concessão de duas loterias para auxiliálo no estabelecimento de tão vantajosa indústria no Brasil. Também em 1840, Zeferino Ferrez, francês estabelecido na Corte, onde havia se casado e constituído família, pedia loterias para sua indústria. Dizia o peticionário estar "convencido de que esta Augusta Câmara assaz almeja (...) elevar este vasto e abençoado Império à eminente ordem das nações grandes, em cuja alta categoria parece que o Árbitro dos Mundos o destinou colocar." E, por estar "certo de que uma das fontes da grandeza nacional é o desenvolvimento da indústria fabril," Ferrez fazia questão de "apresentar uma descoberta assaz vantajosa ao país." Consistia ela numa forma de fazer papel a partir de matérias-primas nativas do Brasil jamais usadas para tal fim como tucú, algodão, pita e aguachima. O peticionário já comunicara a descoberta a membros da Sociedade Auxiliadora da Indústria Nacional que, por sua vez, examinaram a fábrica e verificaram a veracidade dos fatos expostos. Como mais uma prova da qualidade de seu produto, Ferrez enviava um exemplar de cada papel aos legisladores. ${ }^{88}$

No ano de 1841 mais petições de manufatureiros chegaram à Câmara. João Sebastião Ceva e Companhia, fabricantes de fio de vela de cânhamo, desejando promover o avanço da indústria nacional

\begin{abstract}
e notando que já é tempo de ir-se o Brasil forrando a dependência em que está da maior parte de gêneros e manufaturas estrangeiros de mais urgente necessidade, dependência que, certo, por longo tempo tem de ainda pesar sobre a nação brasileira, a não ser o patriótico zelo dos Augustos e Digníssimos Representantes da Nação, que mui atilados, fechando os olhos e dando de mão a mesquinhos interesses do momento asseguram e garantem ao Brasil e aos vindouros um porvir mais venturoso, e vão deste jeito fazendo convergir os espíritos e os capitais para o único verdadeiro e sólido fim, a riqueza e engrandecimento nacional, filhos da indústria, sólida e poderosa alavanca, que tantos Reinos tem alevantado e potentemente engrandecido de tão mesquinhos que eram, deseja portanto o suplicante contribuir com seu escote para bem do Estado.
\end{abstract}

\footnotetext{
87 Petição de Antonio Rodrigues Rino. 18 de julho de 1840. Centro de Documentação e Informação. Arquivo da Câmara dos Deputados. Brasília. Consultado em fevereiro de 2009.

${ }^{88}$ Petição de Zeferino Ferrez. 29 de maio de 1840. Centro de Documentação e Informação. Arquivo da Câmara dos Deputados. Brasília. Consultado em fevereiro de 2009.
} 
O que desejavam os peticionários era isenção dos direitos de importação do cânhamo e das máquinas que a fábrica necessitasse, assim como o privilégio exclusivo da fabricação de fios e cabos por um espaço de 20 anos. Pelo fato de não ter o Brasil estabelecimento que convertesse o linho cânhamo em fio de vela, "que em tantos e tão variados usos e tráfego da vida social é empregado," os peticionários consideravam seu pedido procedente. Ao desenvolvimento da marinha mercante e de guerra, tão dependentes da produção de cordoaria, um estabelecimento desse tipo serviria de grande incentivo; também os lavradores nacionais do linho cânhamo, por terem certeza de venderem seu produto, seriam beneficiados. A conclusão dos fabricantes era que os representantes da nação deveriam imediatamente se convencer de "que nunca seremos o que hoje são as grandes nações se não formos o que elas foram." 89 A defesa da manufatura nacional implicava a adoção do modelo já bem sucedido em outros lugares: proteção ao empreendedor nacional.

Por sua vez, Manoel José Valladares, fabricante de sabão, demandava dos representantes da nação a concessão de 20 loterias. Dizia ele que, já naquele ano de 1841, seu estabelecimento gozava de reconhecida utilidade pública, pois manipulava mensalmente entre duas e três mil arrobas de sabão de reconhecida qualidade. Porém os vôos pretendidos por Valladares eram ainda maiores e, segundo ele, casavam-se com os interesses de toda a nação brasileira. O progresso de seu negócio, acreditava, iria "animar outros ramos da indústria nacional, que ora jazem não conhecidas, endoexploradas, quais a barrilha na província do Ceará, o carvão de pedra na de Santa Catarina e o breu na de São Paulo." Tal empresa, contudo, não poderia nascer apenas das fracas mãos do peticionário que, por isso, contava com o apoio da Augusta Câmara: somente por meio do subsídio requerido poderia ele "dar àquela fábrica o desenvolvimento de que é suscetível e o público terá no mercado sabão nacional sem carecer de que ele venha do estrangeiro.” Além do benefício direto, Valladares reafirmava que o desenvolvimento de sua fábrica incentivaria "aqueles ramos de indústria que, existindo hoje amortecidos, aumentarão a riqueza nacional, fornecerão o sustento a muitos cidadãos necessariamente empregados em seus trabalhos." 90

Dois anos após pedir as 20 loterias para sua fábrica de sabão, Manoel José Valladares reiterava sua súplica com os mesmos argumentos que usara em 1841; porém,

${ }^{89}$ Petição de Sebastião Ceva e Companhia. 11 de agosto de 1841. Centro de Documentação e Informação. Arquivo da Câmara dos Deputados. Brasília. Consultado em fevereiro de 2009.

${ }^{90}$ Petição de Manoel José Valladares. 25 de setembro de 1841. Centro de Documentação e Informação. Arquivo da Câmara dos Deputados. Brasília. Consultado em fevereiro de 2009. 
havia algo a mais na sua segunda petição: ela vinha acompanhada por 67 assinaturas de negociantes da Corte que atestavam que

a fábrica de sabão do senhor Manoel José Valladares na Ponta do Caju se faz credora de todos os elogios, não só pelo vasto edifício em que está, mas também pela perfeição do variado maquinismo, sendo que semelhante fábrica é de suma vantagem não só por tornar nacional uma mercadoria importada por estrangeiros, e cujo consumo é extraordinário, mas porque o preço é muito mais módico, sendo que a qualidade do sabão não é inferior ao estrangeiro. ${ }^{91}$

A voz de Valladares, da primeira vez que se expressara, pouco efeito surtiu; por isso, o peticionário reformulou sua estratégia com a finalidade de provar, a partir firma de homens respeitáveis do Rio de Janeiro, que seu argumento não era desprovido de razão.

Em 1845, Fortuné Banse e Etienne Chantre, cidadãos franceses estabelecidos na Bahia, pediam aos representantes da nação isenção de impostos de importação para sua fábrica de bugias esteáricas. Diziam eles estar

convencidos de que é um dos deveres inerentes ao alto cargo que exerceis o animar por todos os meios possíveis os diversos ramos da indústria a cujo poder existe entregue o cetro do mundo e no Brasil vacila ainda qual tímida criança; persuadidos mais de que nenhuma nação, que com direito aspira à colossal grandeza, pode prescindir de favorecer a introdução e vulgarização desses novos processos com que há conseguido a Europa centuplicar o tempo e os capitais, e que entre vós se acham ainda desconhecidas, ao passo que vossa conterrânea do Norte rivaliza em civilização e prosperidade com as mais antigas Nações do Velho Mundo. ${ }^{92}$

Os empresários franceses apostavam que o caminho para o engrandecimento da nação brasileira se formaria por meio do incentivo governamental à indústria moderna. Incentivo que, em países como os Estados Unidos, já haviam elevado a civilização a patamares jamais imaginados até então. Tudo dependia das concessões daqueles que possuíam a missão de construir sólidas instituições nacionais e contribuir para a civilização do Império - os representantes eleitos da nação.

No ano de 1847, o britânico residente por mais de 30 anos na Corte, Frederico Jones, dizia-se à frente de uma companhia industrial que visava estabelecer na província do Rio de Janeiro uma fábrica de fiar e tecer algodão "movida por máquinas

\footnotetext{
${ }^{91}$ Petição de Manoel José Valladares. 26 de junho de 1843. Centro de Documentação e Informação. Arquivo da Câmara dos Deputados. Brasília. Consultado em fevereiro de 2009.

${ }^{92}$ Petição de Fortuné Banse e Etienne Chantre, cidadãos franceses. 19 de junho de 1845. Centro de Documentação e Informação. Arquivo da Câmara dos Deputados. Brasília. Consultado em fevereiro de 2009.
} 
modernamente inventadas e empregadas nas nações mais adiantadas neste gênero de indústria." Segundo ele, o estabelecimento da empresa seria responsável por

chamar para o país uma soma grande de numerário, dar emprego diário e constante pelo menos a cem pessoas, aumentar o consumo de um gênero de produção agrícola do país, na razão de 400.000 libras de algodão em rama anualmente entregando ao comércio 800.000 jardas de um tecido considerado de primeira necessidade, dar o gosto das fábricas à nação até hoje mui pouco, ou nada, manufatureira, desenvolvendo nela o gênero importantíssimo da indústria fabril, que de certo ela possui e que tem elevado outras nações ao opimo da opulência e para conseqüência da força; - são resultâncias de tão magno proveito e geral utilidade que colocam de primeira intenção a empresa do suplicante na linha das maiores e mais importantes empresas nacionais, digna a todos os respeitos da proteção do governo imperial e dos Augustos e Digníssimos Senhores Representantes da Nação.

Jones requeria a isenção de impostos de importação para materiais utilizados na fábrica e a concessão de duas loterias anuais pelo espaço de cinco anos. O empresário inglês encerrava sua petição se dizendo animado com os princípios adotados nos últimos anos pela representação nacional, "princípios que equivalem um verdadeiro convite e valiosíssimas promessas feitas a todos os Capitalistas do Mundo que quiserem gozar do benéfico e produtivo clima do Brasil, empenhando seus capitais no aumento de sua prosperidade industrial." ${ }^{93}$ A crença que se disseminava era que, ao conceder benefícios ao capital manufatureiro, ganhava todo o país em civilização. Assim entendiam também Justino Meroz e Companhia, fabricantes de colchetes que, vindos de Pernambuco à Corte, visavam reproduzir na capital o negócio que fora bem-sucedido no Recife.

A introdução de um estabelecimento industrial, Augustos e Digníssimos Senhores, sempre foi olhada pelos legisladores das Nações mais cultas como um ato meritório e digno de proteção dos Poderes Públicos, uma vez que fazendo desenvolver o gênio nacional, dá incremento à riqueza do país, emancipando-o da tutela e monopólio estrangeiro sobre o artigo fabricado no meio do próprio povo que tem de ser consumidor. ${ }^{94}$

A idéia que pautava a argumentação era que todos - empresários, Estado e sociedade em geral - se beneficiariam dos auxílios dados às manufaturas. Argumentavam os peticionários que um círculo virtuoso se formaria caso as manufaturas se desenvolvessem no Brasil: não só os beneficiários diretos, mas toda a

\footnotetext{
93 Petição de Frederico Jones. 28 de junho de 1846. Centro de Documentação e Informação. Arquivo da Câmara dos Deputados. Brasília. Consultado em fevereiro de 2009.

${ }_{94}$ Petição de Justino Meroz e Cia. 11 de maio de 1847. Centro de Documentação e Informação. Arquivo da Câmara dos Deputados. Brasília. Consultado em fevereiro de 2009.
} 
economia e, conseqüentemente, toda a nação progrediriam com o enriquecimento da indústria nativa. Sabia-se que toda a comunidade nacional arcaria com privilégios a empresas privadas; todavia, o esforço dos brasileiros - argumentavam os peticionários seria compensado pelo avanço da civilização do Império. A política de incentivos à manufatura demandada pelo empresariado de meados do século XIX tinha como modelo, ainda que distante da realidade concreta do Brasil, a transformação produtiva que revolucionava os países do Atlântico Norte. Não por acaso, muitas das petições eram enviadas por empresários provenientes dos berços da Revolução Industrial. ${ }^{95}$

Os argumentos a favor das concessões à manufatura nacional chegaram ao seu refinamento máximo na petição de Guilherme Telles Ribeiro, datada de 1852. Seu objetivo era "montar em grande escala uma fábrica de cartas de jogar, e obriga-se o suplicante a fabricá-las como as mais perfeitas que se fazem para uso geral e ordinário da sociedade." Para que pudesse, porém, ir em frente com sua empresa seria necessário que os representantes da nação protegessem seu empreendimento. Seus pedidos eram vários e largos: privilégio exclusivo, isenção de impostos, proteção contra falsificadores, taxação sobre cartas importadas, preferência na renovação de contratos etc. Contra aqueles que argumentassem que as concessões à sua fábrica eram prejudiciais à moralidade pública, Telles Ribeiro já estava prevenido:

nem se diga que é uma indústria imóvel e como oposta aos costumes públicos, segurança e saúde dos cidadãos, Art. $179 \quad \S 24$ da Constituição; não, porque o jogo está admitido como uma necessidade indeclinável das sociedades modernas e há de ser satisfeito. É o abuso dele que é nocivo e o que as leis proíbem é ter casa pública de tabulagem para jogos que forem proibidos pelas Posturas, mas não o jogo de cartas em si, divertimento este enraizado indelevelmente nos costumes da sociedade e que equivale neste século industrial e essencialmente pacífico, aos jogos públicos e circos de Gladiadores da Antigüidade e às justas e torneios e às aventuras de Cavalaria da Idade Média. Há sempre em todas as épocas divertimentos próprios delas que ocupem a atenção das horas vagas, e as cartas entram hoje no número dos divertimentos necessários.

Nem se pode argumentar com o abuso, porque com produtos químicos suicida-se o homem, com a lâmina de ferro assassina-se e ninguém condena a indústria que os produz. $\mathrm{O}$ fabrico das cartas de jogar é pois uma indústria tão profícua e indispensável como qualquer outra e merece ser protegida.

Não só a fabricação, mas a própria existência das cartas era inserida no espírito manufatureiro que tomava conta dos empresários brasileiros. Em todos os sentidos,

\footnotetext{
${ }^{95}$ Sobre as relações entre Estado e capitalistas durante a Revolução Industrial na Grã-Bretanha, consultar: Eric Hobsbawm. Industry and Empire. The birth of the Industrial Revolution. Nova York: The New Press, 1999.
} 
então, podia o suplicante defender as vantagens do estabelecimento de sua fábrica. Amostras de cartas acompanhavam a petição: a partir delas os representantes poderiam constatar o quão frutífero seria ter no Brasil uma fábrica do tipo proposto. ${ }^{96}$

O aparente paradoxo desse grupo de petições é significativo para a presente análise: mesmo ao solicitarem favores particulares aos representantes da nação, os empresários legitimavam suas demandas a partir das regras típicas do regime representativo que se instaurava. Suas petições não se assemelhavam às súplicas do Antigo Regime; estavam inseridas na lógica política de seu tempo, eram articuladas em torno do engrandecimento pátrio e da civilização do Império. Os representantes da nação estavam voltados naquele momento para a construção de instituições nacionais; compreendendo este fato, os empresários legitimavam seus pedidos de loterias e isenções a partir da nacionalização do problema do desenvolvimento da manufatura. Não por acaso, argumentavam os peticionários que os favores às empresas privadas, mais do que beneficiarem a este ou àquele indivíduo, propiciariam a elevação "[d]este vasto e abençoado Império à eminente ordem das nações grandes" levando-o, enfim, "à colossal grandeza" e ao "opimo da opulência".

As petições dos manufatureiros não foram as únicas a ocupar a Câmara dos Deputados na década de 1840; também presente em muitas petições do início do Segundo Reinado esteve o problemático tema da organização territorial do Império. A elevação da comarca de Curitiba à categoria de província, por exemplo, se tornou naquele momento uma questão política urgente no seio do parlamento nacional. No ano de 1842, quando paulistas e mineiros haviam se rebelado e os estancieiros do Rio Grande do Sul permaneciam a conduzir a Guerra dos Farrapos, as elites curitibanas juraram sua lealdade ao governo central tendo em vista a desejada separação de sua comarca da província de São Paulo. No entanto, a elevação de Curitiba não foi efetivada sem que os separatistas pressionassem, por meio de petições, os representantes da nação brasileira. $^{97}$

Em 1847 uma petição dirigida de Curitiba, então uma comarca no sul da província de São Paulo, historiava rapidamente o ímpeto separatista de sua região em relação ao governo paulista: "tendo aparecido esta idéia em 1822 abraçada ainda então

\footnotetext{
${ }^{96}$ Petição de Guilherme Telles Ribeiro. 1852. Centro de Documentação e Informação. Arquivo da Câmara dos Deputados. Brasília. Consultado em fevereiro de 2009.

${ }^{97}$ Os estudos mais recentes acerca da criação da província do Paraná são de Vítor Marcos Gregório. "A criação da província do Paraná: uma agenda de pesquisa". Conferência apresentada junto ao $I V$ Congresso Internacional de História. Maringá: 2009. Disponível no endereço eletrônico: http://www.pph.uem.br/cih/anais/trabalhos/172.pdf. Acessado em 09 de dezembro de 2009.
} 
por um pequeno número de pessoas, foi pouco a pouco engrossando à medida que embaraços se apresentaram, de maneira que hoje se pode dizer que o grito separatista é uníssono." A petição fora assinada por 19 autoridades da comarca (vigários, delegados e magistrados), porém os signatários apresentavam-se como porta-vozes de todos os habitantes de Curitiba e expunham aos representantes da nação as vantagens que aquela região possuía em relação a diversas outras do país: território extenso, terra fértil e própria para todo tipo de cultivo, muitos habitantes, portos excelentes, renda elevada, tribos indígenas domesticáveis etc. Tudo conspirava para que, independente, Curitiba viesse a incrementar a riqueza do Império brasileiro. ${ }^{98}$

Dos mesmos argumentos se utilizaram os 75 habitantes da vila Nova do Príncipe que assinaram, também em 1847, sua petição em prol da independência da comarca em relação a São Paulo. Diziam eles que a comarca de Curitiba, "com população superior a 60 mil habitantes, assaz fértil e rica, com exuberantes rendas para suas despesas futuras" estava "por sem dúvida em circunstâncias de formando uma nova estrela da coroa imperial, crescer rapidamente no caminho de mais ampla prosperidade." Sob o nome de cada um dos signatários estava a ocupação que exerciam: eram magistrados, religiosos, funcionários públicos, oficiais da Guarda Nacional, proprietários de terras e negociantes. Na sua percepção, a distância da capital paulista prejudicava as possibilidades de enriquecimento dos povos curitibanos. Sendo assim, buscavam convencer os deputados gerais a abraçar sua causa que já havia sido, segundo eles, adotada por todo o povo da região:

quando uma convicção profundamente radicada constantemente se manifesta com todo o apanágio da justiça e força, Augustos e Digníssimos Senhores Representantes da Nação, que vós satisfaçais este desiderato, que nem um modo prejudicando os interesses gerais, pode em máximo grau concorrer para a felicidade de sessenta e tantos mil brasileiros. ${ }^{99}$

O interesse nacional não seria ferido pela separação; muito pelo contrário, ele seria promovido pela criação de mais uma província fiel ao Estado imperial. Assim também pensavam os autores da mais longa e enfática petição a favor da separação curitibana: datada de 1850, ano do retorno do projeto de elevação do Senado para a Câmara, ela era assinada por 121 pessoas, porém dizia-se feita em nome de 13 mil. Os

\footnotetext{
${ }^{98}$ Petição dos habitantes de Curitiba. 25 de fevereiro de 1847. Centro de Documentação e Informação. Arquivo da Câmara dos Deputados. Brasília. Consultado em fevereiro de 2009.

99 Petição dos habitantes da vila Nova do Príncipe. 09 de abril de 1847. Centro de Documentação e Informação. Arquivo da Câmara dos Deputados. Brasília. Consultado em fevereiro de 2009.
} 
peticionários da vila de Castro argumentavam que Curitiba não poderia mais "sem quebra de seu progresso material e moral pertencer a uma província de cuja capital dista mais de cem léguas do seu centro." Contava favoravelmente para a separação o fato de que, mesmo abandonada à própria sorte, a comarca apresentava notável progresso no cultivo da erva mate, que exportava para Montevidéu e Buenos Aires e, em pouco tempo, se notabilizaria por uma variada indústria agrícola: a cana, o café, o fumo, o chá, o algodão, o trigo e a erva vegetavam admiravelmente em diferentes partes da comarca, sendo que esta última constituía ainda uma forma simples e segura para a garantia de sobrevivência de sua população pobre. Próprias seriam também, segundo aqueles agricultores, comerciantes e criadores, suas florestas para o estabelecimento de colônias de trabalhadores estrangeiros; suas extensas campinas seriam ótimas para a criação de muares, cavalos, gado vacum e ovelhas, destinados a abastecer a população local e os mercados distantes; sem muita dificuldades, os indígenas que vagavam pelos desertos da comarca poderiam ser trazidos à sociedade, feito este que seria útil para o acréscimo da população e, principalmente, para o cumprimento do dever moral de se dar idéia de civilidade àqueles que "jazem nas selvas entregues aos seus próprios instintos, com afronta da civilização do século em que vivemos." O rico porto de embarque localizado em Antonina, com suas estradas que o ligavam a todos os pontos da comarca, seria ainda mais uma fonte de rendas para o Estado brasileiro. A vital questão de conservação das fronteiras nacionais seria também beneficiada pela criação da província, pois ali estabelecida uma capital provincial poder-se-ia com mais facilidade fazer respeitar o território brasileiro pelos vizinhos republicanos.

Os habitantes de Castro terminavam sua petição com uma espécie de síntese do que os curitibanos buscavam ao escrever à Câmara dos Deputados na década de 1840: diziam que os interesses de sua comarca eram muito diferentes daqueles de São Paulo e que seus

lugares cheios de tanta riqueza e em tal estado de abandono parecem chocar os princípios de direito público, oferecendo resultados repugnantes com as idéias sociais dos nossos tempos. Se tais incentivos já foram um meio para o no $11^{\circ}$ século ser combatido o feudalismo dos tempos de Carlos Martel, parece que na época atual em que a segregação das massas não pode deixar de concorrer para a manutenção da associação política deste Império e oferecer maior estabilidade, não será desatendida a súplica de uma população inteira, que procurando acompanhar o progresso do mundo civilizado, 
propugna pelos meios de animar ao seu desenvolvimento e engrandecimento material e moral. ${ }^{100}$

A questão da estabilidade política do país era explicitamente colocada diante dos representantes da nação. A lembrança das guerras das décadas precedentes estava fresca na memória da população e dos políticos nacionais. Estrategicamente, os peticionários de Castro invocavam o fantasma das massas descontroladas e apelavam para o ideal de civilização. A independência da comarca seria positiva para toda a comunidade nacional, pois, além do enriquecimento do Império, teria como conseqüência a manutenção de sua estabilidade política. Do ponto de vista dos castrenses, agir contra a maré da vontade dos curitibanos seria um atentado contra o interesse da nação brasileira de um modo geral.

No ano de 1851, chegou à Câmara dos Deputados uma petição proveniente da vila de Antonina: os "negociantes, lavradores e operários" daquela vila deixavam claro que a sede do governo paulista nada fazia para o bem de sua comarca. Seria um ato irracional dos deputados a não aprovação do projeto vindo do Senado que visava elevar Curitiba à categoria de província. Os 101 signatários da petição pediam com veemência que os representantes da nação tomassem os seus interesses como os melhores para o país. Era um dos passos derradeiros da luta que envolvera, por muitos anos, alguns setores influentes da comarca de Curitiba no esforço contra o governo provincial paulista. ${ }^{101}$ No mesmo ano de 1851, 61 lavradores, autoridades, guardas nacionais e negociantes da vila de Morretes também pediram à Câmara a mais séria atenção para a medida que se constituía como a única maneira de proteger o progresso que, de dia em dia, a comarca de Curitiba estava a desenvolver tanto em civilização quanto em agricultura e indústria. Os habitantes de Morretes adotavam um tom conciliador para com a elite política paulista: diziam que ela "julgou talvez que a desmembração desta parte importante da província pode tirar sua antiga e bem merecida fama," porém devia “antes lembrar-se que a grande porção por ela descoberta a força de perseverança e trabalho está hoje elevada à província sem que esta tenha perdido nada de seu brilho." Usando o exemplo de Minas Gerais, que durante o período colonial havia sido

${ }^{100}$ Petição dos agricultores, comerciantes e criadores habitantes da vila de Castro. 04 de junho de 1850 . Centro de Documentação e Informação. Arquivo da Câmara dos Deputados. Brasília. Consultado em fevereiro de 2009.

${ }^{101}$ Petição dos negociantes, lavradores e operários da vila de Antonina. 12 de junho de 1851. Centro de Documentação e Informação. Arquivo da Câmara dos Deputados. Brasília. Consultado em fevereiro de 2009.

${ }_{102}$ Petição dos residentes na vila de Morretes. 31 de maio de 1851. Centro de Documentação e Informação. Arquivo da Câmara dos Deputados. Brasília. Consultado em fevereiro de 2009. 
primeiramente povoada por exploradores paulistas, os curitibanos tentavam se reconciliar com a província de São Paulo e demonstrar que a separação traria apenas benefícios para a nação brasileira.

Em 26 de agosto 1853, a Assembléia Geral decretava e o imperador D. Pedro II sancionava uma lei que determinava que a comarca de Curitiba seria elevada à categoria de província, com a denominação de Paraná. Apesar das petições curitibanas terem defendido a posição de uma elite local contra o governo paulista, seu discurso, estrategicamente elaborado, demonstrara que a criação da província do Paraná era uma medida concernente ao interesse nacional. Somente dessa forma sua demanda pôde ser considerada legítima pelos representantes da nação brasileira: as petições curitibanas estavam inseridas na lógica do regime político sob o qual o Império era regido. A sua argumentação não determinou a vitória da causa separatista; havia outras questões envolvidas, como a fidelidade dos curitibanos ao governo central quando do levante de 1842. No entanto, não há como negar que os peticionários influenciaram as decisões dos representantes da nação na medida em que fundamentaram politicamente a proposta separatista: a separação de Curitiba transcendia os limites da comarca, dizia respeito à estabilização e ao progresso do Império como um todo; somente assim as petições curitibanas puderam adentrar o debate acerca da organização territorial brasileira e auxiliar na negociação acerca da divisão provincial do atribulado Sul do Império.

O sucesso dos curitibanos não estabeleceu, todavia, uma regra: outros grupos separatistas não obtiveram a mesma repercussão no parlamento nacional. Foi o caso, por exemplo, dos habitantes do termo de Paraguaçu, pertencente à vila de Bragança da província do Pará, que, por meio de uma petição contendo 259 assinaturas, requereram que o termo em que viviam fosse integrado ao Maranhão. Todo o argumento dos peticionários estava baseado na seguinte crença: "nas divisões civis devem conciliar-se o mais possível os interesses dos povos com as divisões naturais como rios, montanhas e outras semelhantes.” Isto posto, justificavam-se: “ora, para a desmembração proposta concorrem e se auxiliam reciprocamente os interesses dos povos, as tradições e a melhor divisão natural.” Segundo eles, a navegação de Paraguaçu até Bragança levava oito dias e, de lá para Belém, a situação era deveras precária já que o território atravessado "quase um deserto" - contava com apenas três estabelecimento. As únicas relações que os habitantes de Paraguaçu mantinham com a capital do Pará eram "as judiciárias, administrativas e políticas, puramente obrigatórias; e para apartá-los de tais centros de administração civil e judiciária concorrem, além dos obstáculos naturais já apontados, 
rivalidades inveteradas com os povos de Bragança." Reclamavam ainda que, "durante a terrível anarquia de 1835, bandos armados vindos de Bragança assaltaram e invadiram a nossa vila, cometendo assassinatos, roubos e todo o gênero de depredações." A dificuldade das comunicações e o ódio em relação aos bragantinos impediam que chegassem da capital os socorros necessários às suas agruras: o estado de abandono trouxera decadência e empecilhos para o desenvolvimento do termo de Paraguaçu. Continuavam:

além das invasões revolucionárias, a permanente falta de polícia dá facilidade e ocasião a freqüentes crimes particulares; a isto junte-se a permanência de grandes quilombos de escravos fugidos das comarcas de Viana, Alcântara e Guimarães da província do Maranhão. Assim, gravemente compreendida quase sempre a segurança individual e de propriedade, alguns habitantes têm regressado para o Maranhão.

Com a anexação ao Maranhão os males cessariam e novas vantagens seriam obtidas: as viagens até São Luís levavam de 4 a 5 dias e a volta apenas 2 ou 3; as necessidades judiciárias, administrativas e políticas encontrariam maior prontidão não só pela facilidade de comunicação, mas também pelas relações de origem, afeição, parentesco e comércio que os habitantes de Paraguaçu possuíam com os maranhenses.

De todas estas mudanças serão conseqüências imediatas o incremento da população, agricultura, riqueza e prosperidade do termo. O rio Gurupy parece ser a divisão natural das duas províncias, pois é o maior daquelas paragens, o que mais avante deriva dos sertões adentro, o que separa enfim populações de origens e relações espontâneas diversas. ${ }^{103}$

Em tom muito próximo ao dos habitantes de Paraguaçu, também expunham sua demanda separatista à Câmara os habitantes do município do Bananal, província de São Paulo. A petição - assinada por um grupo de 481 cidadãos que incluía fazendeiros, autoridades, negociantes, estudantes, farmacêuticos, médicos, advogados, artesãos etc. argumentava que o melhor para o município seria sua anexação à província do Rio de Janeiro. Diziam eles não fazer questão de serem fluminenses ou paulistas, pois eram brasileiros, mas "se a divisão territorial tem por único fim a comodidade dos povos, e fazer chegar a ação dos governantes aos governados com mais presteza," qual seria então - indagavam - "a razão por que os abaixo assinados se vejam condenados a pertencer à capital de São Paulo, distante 68 léguas, quando só distam da Corte 28?” Bananal se encontrava entre dois municípios fluminenses, Angra dos Reis e Rezende, e

103 Petição dos habitantes do termo de Paraguaçu. 1850. Centro de Documentação e Informação. Arquivo da Câmara dos Deputados. Brasília. Consultado em fevereiro de 2009. 
nenhuma transação tinha com a cidade de São Paulo, ao passo que todo o seu comércio era voltado para o Rio de Janeiro; de lá traziam suas máquinas, seu sustento e seu vestuário:

por que razão hão de estar sujeitos a uma capital que não pode ministrar-lhes todos os socorros que dependem do governo provincial, que muitas vezes as desconhece pela longitude e pela nenhuma relação comercial que existe entre o município e a capital? Entretanto que suas requisições seriam devidamente apreciadas pela capital do Rio de Janeiro onde são conhecidos, onde sua importância agrícola e comercial é notória. ${ }^{104}$

As petições vindas de Bananal e de Paraguaçu não causaram o mesmo impacto das petições dos curitibanos sobre o debate parlamentar. Um dos motivos para sua ineficácia certamente foi sua incapacidade de demonstrar que a mudança que propunham dizia respeito ao interesse nacional. Conforme argumentavam os próprios paraguaçuenses, as medidas demandadas nessas petições trariam "o incremento da população, agricultura, riqueza e prosperidade do termo" (ênfase minha); entretanto, os representantes da nação estavam preocupados com a realidade brasileira como um todo e não com as necessidades particulares de agrupamentos locais.

Evidentemente, outros muitos elementos além da retórica dos curitibanos determinaram seu sucesso contra a província paulista; igualmente, não foi apenas a incapacidade argumentativa que determinou que bananalenses e paraguaçuenses fossem malsucedidos. Contudo, o impacto causado no parlamento por cada uma das petições esteve ligado ao tipo de discurso nelas contido. Preocupados com a construção de instituições nacionais e com o engrandecimento e a civilização do Império, os parlamentares brasileiros não podiam desviar seu foco para resolver problemas restritos a uma localidade. Os grupos interessados em uma mudança com repercussão nacional, como eram as questões jurisdicionais, tinham de adequar sua demanda à lógica do regime que fundamentava a vida política no Império. É possível traçar aqui uma comparação com o exemplo dos abolicionistas britânicos tratado no capítulo 1: enquanto colocaram sua demanda como uma exigência moral quaker, eles obtiveram pouca atenção dos parlamentares, sendo tratados apenas como uma seita radical; quando, porém, pintaram o fim da escravidão como um benefício para toda a GrãBretanha obtiveram apoio entusiasmado - tanto dentro quanto fora do parlamento - para sua causa. Ou seja, suas petições tiveram que se adequar às regras do jogo político (isto

104 Petição dos habitantes do município do Bananal. 1853. Centro de Documentação e Informação. Arquivo da Câmara dos Deputados. Brasília. Consultado em fevereiro de 2009. 
é, do regime representativo) para causarem verdadeiro impacto sobre o debate legislativo acerca das instituições nacionais.

Cabe, neste momento, um parêntesis: afirmar que a atividade peticionária do Império sofreu uma profunda transformação durante as primeiras décadas do Segundo Reinado não significa, contudo, dizer que ela aparecia naquele momento tal qual aparecera na Inglaterra abolicionista. As massas ainda não se constituíam como um ator político organizado frente ao parlamento e, por isso, se viam excluídas do debate público acerca da construção das instituições nacionais nos primeiros anos do reinado de D. Pedro II. Um movimento popular comparável ao abolicionismo britânico só apareceu no Brasil, de fato, na década de 1880 quando, inspirados pela experiência dos ativistas ingleses, Nabuco, Patrocínio, Rebouças, Antonio Bento e outros mais promoveram a luta final pela emancipação dos escravos em solo brasileiro. ${ }^{105}$ Ainda que esta dessemelhança seja clara, os exemplos trabalhados acima mostram que pelo menos uma das características centrais da atividade peticionária sob o regime representativo já se desenvolvia no Brasil do início do Segundo Reinado: muitas petições, naquele momento, deixavam de ser apenas porta-vozes de súplicas por justiça perante um soberano todo-poderoso e passavam a contribuir ativamente para a definição do interesse nacional.

Conflitos entre interesses concretos dentro do parlamento existiam no Brasil como nos demais Estados Nacionais do século XIX - e eram fundamentais para a aprovação de leis e para a definição das instituições nacionais. Isto não impedia, contudo, que a negociação política fosse permeada pelo discurso do interesse nacional; pelo contrário, o ideal de que a legislação deveria estar sempre de acordo com a vontade geral dava parâmetros ao que seria considerado legítimo (ou ilegítimo) quando projetos políticos divergentes se enfrentassem no seio da representação nacional. Interesses particulares presentes na sociedade brasileira nunca foram abolidos, nem mesmo quando a monarquia constitucional se firmou; entretanto, eles tiveram de se adequar à lógica do regime representativo para poderem ganhar repercussão sobre o parlamento do Império.

A adoção do ideal da vontade geral por parte de certos setores da sociedade governada foi essencial para que a atividade peticionária adquirisse importância política durante o Segundo Reinado: como buscarei demonstrar nos capítulos que seguem, a

\footnotetext{
105 Sobre o movimento abolicionista no Império, consultar: Robert E. Conrad. Os Últimos Anos da Escravatura no Brasil. Rio de Janeiro: Civilização Brasileira, 1978.
} 
capacidade do discurso peticionário demonstrar aos legisladores que suas demandas transcendiam um interesse particular - e, conseqüentemente, tratavam de questões relevantes para todo o país - foi determinante para o tipo de repercussão que causaram sobre os legisladores. Fazia parte do jogo político da monarquia constitucional a adequação dos diversos interesses presentes na sociedade ao esforço de construção de um interesse nacional.

A historiadora Lúcia Maria B. P. das Neves constata que, já durante o processo de independência, prevalecia na imprensa periódica brasileira a preocupação com o pacto social da nova nação, tendo as questões relativas estritamente aos interesses particulares sido relegadas ao segundo plano. "Abria-se mão das preocupações com os indivíduos, em especial com os pertencentes a um grupo de privilegiados, e passava-se a pensar a Nação como um todo, utilizando-se a palavra a serviço do ideal liberal." ${ }^{106}$ No caso das petições, como foi possível notar até aqui, a nacionalização das demandas levou um tempo maior para se estabelecer e mesmo na década de 1840 ainda não se tinha - conforme mostram os exemplos dos bananalenses e dos paraguaçuenses - uma clara compreensão por todos os setores da sociedade acerca do tipo de debate que se impunha no parlamento imperial. No entanto, é possível defender que a afirmação do regime representativo durante os primeiros anos do Segundo Reinado foi responsável por paulatinamente nacionalizar as petições, transformando-as de portadoras de queixas particulares (conforme acontecia no Antigo Regime e no Primeiro Reinado) em defensoras de propostas para a construção do Estado Nacional.

A fim de deixar claro este aspecto inovador da atividade peticionária do Segundo Reinado, enumero aqui mais alguns exemplos de petições que tratavam de questões concernentes à nação como um todo: em 1842, a Assembléia Legislativa de Pernambuco propôs à Câmara a mudança da Academia de Direito de Olinda para Recife, pois acreditava que na capital pernambucana o mais fácil acesso aos benefícios da civilização melhoraria a vida de estudantes e professores, melhorando também a educação dos futuros magistrados brasileiros; ${ }^{107}$ em 1843, a Assembléia de Santa Catarina demandava uma lei de sesmarias que incentivasse a ocupação e a extração de

\footnotetext{
${ }^{106}$ Lúcia Maria B. P. das Neves. "Opinião Pública” In: João Feres Júnior (org.). Léxico da História dos Conceitos Políticos do Brasil. Belo Horizonte: UFMG, 2009. p. 188.

${ }^{107}$ Petição da Assembléia Legislativa de Pernambuco. 30 de abril de 1842. Centro de Documentação e Informação. Arquivo da Câmara dos Deputados. Brasília. Consultado em fevereiro de 2009.
} 
riquezas do solo nacional; ${ }^{108}$ em 1844, a Assembléia Provincial do Maranhão, preocupada com os abusos que se repetiam, pedia à Câmara uma lei que regulamentasse a cobrança de juros sobre empréstimos em todo o território brasileiro; ${ }^{109}$ em 1846, o doutor Bento Mure propunha que a Câmara transformasse em lei uma técnica de se enterrar cadáveres que contribuiria para a saúde pública das mais populosas cidades do Império; ${ }^{110}$ em 1847, 160 negociantes da Praça do Rio de Janeiro assinavam uma petição contra um "abuso escandaloso que corrói, definha e aniquilará ao fim o comércio a retalho," qual fosse: a circulação de mascates, denominados "vulgarmente italianos"; ${ }^{111}$ também em 1847, o lavrador baiano Teófilo de Mello pedia aos representantes da nação a abolição dos iníquos e anticonstitucionais privilégios concedidos à lavoura da cana-de-açúcar, privilégios estes que, acreditava ele, faziam apenas com que aquele cultivo retrogradasse ao invés de progredir e geravam graves problemas aos outros cultivos e grandes perdas para os cofres públicos; ${ }^{112}$ em 1848, a Assembléia Provincial do Rio de Janeiro pedia medidas legislativas para facilitar a naturalização de estrangeiros afim de atrair europeus dispostos a trabalhar em terras brasileiras; ${ }^{113}$ também em 1848, Vitorino Ribeiro d'Oliveira e Silva propunha que a representação nacional adotasse alguma medida para defender os cidadãos brasileiros que fossem processados por procuradores de estrangeiros que não residissem no país; ${ }^{114}$ em 1850, a câmara municipal de Queluz, província de Minas Gerais, solicitava da Câmara uma reforma da Guarda Nacional; ${ }^{115}$ ainda em 1850, João Vicente Martins propunha aos deputados gerais a oficialização da medicina homeopática como forma de acabar com a "horrorosa mortandade" que afligia o Império; ${ }^{116}$ em 1851, os "órgãos de

\footnotetext{
${ }^{108}$ Petição da Assembléia Legislativa de Santa Catarina. 06 de maio de 1843. Centro de Documentação e Informação. Arquivo da Câmara dos Deputados. Brasília. Consultado em fevereiro de 2009.

${ }^{109}$ Petição da Assembléia Legislativa do Maranhão. 14 de agosto de 1844. Centro de Documentação e Informação. Arquivo da Câmara dos Deputados. Brasília. Consultado em fevereiro de 2009.

${ }^{110}$ Petição do doutor Bento Mure. 20 de agosto de 1846. Centro de Documentação e Informação. Arquivo da Câmara dos Deputados. Brasília. Consultado em fevereiro de 2009.

${ }^{111}$ Petição dos negociantes da Praça de comércio do Rio de Janeiro. 20 de julho de 1847. Centro de Documentação e Informação. Arquivo da Câmara dos Deputados. Brasília. Consultado em fevereiro de 2009.

${ }^{112}$ Petição de Teófilo de Mello. 06 de maio de 1847. Centro de Documentação e Informação. Arquivo da Câmara dos Deputados. Brasília. Consultado em fevereiro de 2009.

${ }^{113}$ Petição da Assembléia Legislativa do Rio de Janeiro. 11 de agosto de 1848. Centro de Documentação e Informação. Arquivo da Câmara dos Deputados. Brasília. Consultado em fevereiro de 2009.

114 Petição de Vitorino Ribeiro d'Oliveira e Silva. 21 de agosto de 1848. Centro de Documentação e Informação. Arquivo da Câmara dos Deputados. Brasília. Consultado em fevereiro de 2009.

${ }^{115}$ Petição da câmara municipal de Queluz. 22 de maio de 1850. Centro de Documentação e Informação. Arquivo da Câmara dos Deputados. Brasília. Consultado em fevereiro de 2009.

${ }^{116}$ Petição de João Vicente Martins. 15 de fevereiro de 1850. Centro de Documentação e Informação. Arquivo da Câmara dos Deputados. Brasília. Consultado em fevereiro de 2009.
} 
comércio da Paraíba do Norte" clamavam pela revogação da Lei de 28 de outubro de 1848 que, segundo eles, restringia o comércio de importação das províncias pequenas, empobrecendo-as, e agravava a desigualdade inter-regional; ${ }^{117}$ também em 1851, a câmara de Campos dos Goytacazes queixava-se da Lei de $1^{\circ}$ de outubro de 1828, que criara e regulara as atribuições das câmaras municipais, e pedia sua reforma com a finalidade de obter mais autonomia para a administração dos municípios brasileiros. ${ }^{118}$

A lista de exemplos se estenderia ainda mais, porém os que foram até aqui citados são suficientes para se compreender como o direito de petição foi apropriado por setores da sociedade brasileira que buscaram influenciar no ordenamento político do Império. Nem todos foram bem-sucedidos, evidentemente; entretanto, os cidadãos foram capazes de esclarecer os representantes da nação sobre suas expectativas, participando, assim, ativamente das negociações políticas que definiam o interesse nacional. Por mais que falassem em nome dos interesses concretos de comerciantes, de elites políticas regionais, de fazendeiros, de profissionais liberais, de empresários, de religiosos, de militares ou de quaisquer outros grupos, as petições do início do Segundo Reinado se voltavam para a construção das instituições da jovem nação; elas eram instrumentalizadas por setores da sociedade que, para além de defender o seu interesse particular, participavam do debate acerca da organização do país de um modo geral. Cabe repetir que não havia no Brasil da década de 1840 movimentos populares como o abolicionismo britânico, mas havia sim um intenso diálogo entre representantes e representados quanto à definição do interesse nacional.

A primeira década do Segundo Reinado foi um período de transição durante o qual os peticionários não mais se comportaram apenas como súditos à espera da justiça emanada das mãos do soberano. Naquele momento o Poder Legislativo do Império também passava por uma importante transformação: assumia definitivamente a função que lhe seria peculiar no século XIX onde quer que o regime representativo fosse implantado; ou seja, o parlamento brasileiro, em meio às transformações políticas da década de 1840 , se mostrava capaz de gerir institucionalmente os conflitos políticos presentes na sociedade nacional. De maneira cada vez mais intensa, a legislação se baseava sobre as necessidades expressas por relevantes setores da sociedade governada,

\footnotetext{
${ }^{117}$ Petição dos órgãos de comércio da Paraíba do Norte. Agosto de 1851. Centro de Documentação e Informação. Arquivo da Câmara dos Deputados. Brasília. Consultado em fevereiro de 2009.

118 Petição da câmara municipal de Campos dos Goytacazes. 11 de abril de 1851. Centro de Documentação e Informação. Arquivo da Câmara dos Deputados. Brasília. Consultado em fevereiro de 2009.
} 
mantendo sua legitimidade ao buscar sempre adequar-se ao ideal do interesse nacional. A partir do estabelecimento de uma relação direta entre governantes e governados, a representação política ganhava concretude no Brasil.

Os peticionários, caso quisessem ser bem-sucedidos, não podiam se opor à lógica do sistema que governava o país; o Estado Nacional brasileiro se consolidava e, concomitantemente, a sociedade governada passava por um aprendizado político que previa a absorção das regras do regime representativo. Debater sobre o interesse nacional se tornava missão de todos os cidadãos brasileiros, ainda que a última palavra coubesse aos seus representantes eleitos reunidos em uma assembléia de homens ilustres. Por meio do diálogo que se estabelecia naquele momento, as instituições nacionais eram construídas e o regime se fortalecia. Sem emanar diretamente da sociedade governada, a vontade geral se constituía a partir de um processo em que diversos atores - tanto de dentro quanto de fora do parlamento - negociavam tendo sempre em vista a realidade política nacional. 


\section{CAPÍTULO 3. AS "ELEIÇÕES DO CACETE" E A QUESTÃO DA LEGITIMIDADE DA REPRESENTAÇÃO POLÍTICA NO IMPÉRIO}

A historiografia que se dedicou às eleições do Brasil oitocentista sofreu por um bom tempo com o eco que os próprios historiadores fizeram daqueles que, no calor do momento, se envolveram nas disputas eleitorais. Escritos de grande importância histórica como os de João Francisco Lisboa, Francisco Belisário, Nabuco de Araújo, José de Alencar e Tavares Bastos - todos eles homens profundamente envolvidos na vida política de seu tempo - foram tomados como relatos imparciais das eleições no Império. Fraude e violência eram os fatores que, conforme apontavam esses autores, deslegitimavam os processos eleitorais no Brasil oitocentista. ${ }^{119}$

Felizmente, presencia-se hoje uma renovação dos estudos sobre eleições no Império brasileiro. Historiadores têm contextualizado a crítica contemporânea acerca da corrupção do processo eleitoral e têm prestado atenção no significado que o mesmo processo adquiriu para a população envolvida. Lúcia Maria B. P. das Neves, por exemplo, mostra que, a partir do processo de independência, uma nova cultura política tomou conta do país e, sobretudo, da Corte, onde estava localizado não só o imperador e seus ministros, mas também o parlamento nacional. Esta nova cultura foi responsável por retirar a política dos círculos palacianos e colocá-la na praça pública; conseqüentemente, a participação dos cidadãos na política mostrou-se irreversível. Símbolo da transformação pela qual o Brasil passava, o processo eleitoral se tornou aspecto central da vida do Império. ${ }^{120}$

Já em 1821, quando os luso-americanos elegeram seus representantes para as Cortes de Lisboa, ressaltava-se o aspecto liberal da experiência eleitoral. Contemporâneo ao processo, o jornalista Basílio Ferreira Goulart explicava aos seus concidadãos: "nós não temos outra arma, senão o nosso voto: isto é, com que defenderemos nossos direitos, nossos foros pelos nossos representantes."121 Eleger, afirmavam os publicistas da época, transformava-se numa obrigação cívica já que o

\footnotetext{
${ }^{119}$ Segundo o historiador Eduardo Posada-Carbó, a historiografia latino-americana de um modo geral sofreu do mesmo mal por muito tempo. "Electoral Juggling: a comparative history of the corruption of suffrage in Latin America, 1830-1930". Journal of Latin American Studies. Volume 32, número 3, Outubro de 2000.

${ }^{120}$ Lúcia Maria B. P. das Neves. "Las elecciones en la construcción del Império Brasileño: los límites de una nueva práctica de la cultura política lusobrasileña (1820-1823)" In: Antonio Annino (coord.). Historia de las Elecciones en Ibero América, Siglo XIX. De la formación del espacio político nacional. México: Fondo de Cultura Económica, 1995. p. 383.

${ }^{121}$ Basílio Ferreira Goulart apud Idem. Ibidem. p. 394.
} 
eleito seria o responsável pela legislação que conduziria a vida da nação. Conforme explica Neves, "el deputado era una figura clave de la política liberal, pues se situaba en el centro del sistema representativo. Traducía una imagen política, que debía ser la de un ciudadano honesto, un político virtuoso y un individuo letrado, exigiéndose los atributos de la virtud y de la sabiduría en su plenitud." ${ }^{\prime 22}$ Escolher os melhores dentre os cidadãos para representar a nação numa assembléia de homens notáveis: eis a tarefa que se colocava para os eleitores da América portuguesa em 1821. O eleitor era o elemento de ligação entre a sociedade e seus representantes, por isso deveria exercer sua função com o maior zelo possível. Após a ruptura dos laços com Portugal, esse ideário, típico do liberalismo do século XIX, foi fundamental para a consolidação da monarquia constitucional brasileira. A partir de então, participar do processo eleitoral significava estar inserido na construção das instituições nacionais, significava exercer o poder soberano. Somente o voto cidadão poderia legitimar a atuação daqueles que eram considerados "patriarcas da Nação", "fundadores da Pátria", "alicerces do Estado". ${ }^{123}$

Fixado o ideário liberal acerca das eleições em meio às atribulações do Primeiro Reinado e da Regência, o Segundo Reinado foi inaugurado por uma grande polêmica sobre a intervenção do governo no processo eleitoral. As "eleições do cacete", segundo analistas da época, haviam subvertido a boa ordem do regime representativo brasileiro. Conduzido pelo governo daqueles que haviam liderado o Movimento da Maioridade, este evento foi intensamente debatido pela sociedade nacional e também pelos seus representantes. O historiador Jeffrey Needell chama a atenção para o fato de o Golpe da Maioridade ter sido levado a cabo com a finalidade de se conquistar uma maioria parlamentar por meio do controle das eleições: "what was clearly at stake by April 1840 was not only which party was in power, but which would entrench themselves there through electoral influence from the Court." ${ }^{\text {124 }}$ A Regência vivia uma crise no momento em que os liberais moderados, vitoriosos em 1831 ao derrubarem D. Pedro I, se dividiam em dois grupos antagônicos. Em oposição àqueles que haviam se apossado do Poder Executivo desde 1837, figuras ilustres da política nacional se reuniram na casa de um senador pelo Ceará, o padre José Martiniano Pereira de Alencar, para traçar um plano de ascensão: fundava-se o Clube da Maioridade.

\footnotetext{
${ }^{122}$ Idem. Ibidem. p. 395.

${ }^{123}$ Idem. Ibidem. p. 396.

124 Jeffrey Needell. The Party of Order: the conservatives, the State, and slavery in the Brazilian monarchy. 1831-1871. Stanford: Stanford University Press, 2006. p. 83.
} 
O grupo político que ficou conhecido como regressista detinha o poder desde a queda do regente paulista Diogo Antônio Feijó. Sobretudo no que dizia respeito ao Poder Judiciário, seu projeto político visava dar força aos delegados do governo central em detrimento de algumas prerrogativas conquistadas pelos poderes locais durante o primeiro período da Regência; deste modo, os seus adversários denominaram-nos de partido do Regresso. Ainda que formassem na província fluminense um grupo homogêneo e regrado (liderado por figuras como Joaquim José Rodrigues Torres e Bernardo Pereira de Vasconcelos), os regressistas não foram capazes de conter a instabilidade política que marcou o fim da década de 1830 em certas províncias do Império - sobretudo Rio Grande do Sul, Bahia e Maranhão. Frente a tal quadro, a coroação antecipada do jovem herdeiro do trono parecia uma oportunidade plausível para a conquista do poder pelas lideranças que haviam sido excluídas pela política do Regresso: mobilizando elementos populares da Corte, causando tumulto dentro do parlamento e ameaçando os regressistas, os defensores da maioridade conduziram um golpe que elevou um menino de 14 anos ao posto de imperador e que lhes permitiu ocupar o Poder Executivo. ${ }^{125}$

O primeiro ministério escolhido por D. Pedro II ficou conhecido como Gabinete Maiorista, daí os seus aliados políticos também terem sido denominados maioristas no começo da década de 1840. Os membros do ministério eram importantes lideranças políticas que se opunham aos regressistas: os irmãos paulistas Antônio Carlos Ribeiro de Andrada Machado e Silva e Martim Francisco Ribeiro de Andrada; o líder mineiro (nascido em Lisboa) Antonio Paulino Limpo de Abreu; os irmãos pernambucanos Antônio Francisco de Paula de Holanda Cavalcanti de Albuquerque e Francisco de Paula Cavalcanti de Albuquerque; além do fluminense Aureliano de Sousa e Oliveira Coutinho. Outras figuras importantes do movimento, como o cearense Alencar e o mineiro Teófilo Benedito Ottoni, não fizeram parte do gabinete, mas foram enviadas para as províncias para firmar o seu domínio.

Marcadas para os últimos meses de 1840, as eleições para a legislatura que se iniciaria em 1842 foram controladas pelo Gabinete Maiorista; em torno deste controle se desenvolveu uma grande polêmica dentro e fora do parlamento no ano de 1841 . Polarizaram-se, então, na Câmara dos Deputados, dois grupos: por um lado se colocaram os defensores da legitimidade das eleições, ou seja, os adeptos do Gabinete

\footnotetext{
${ }^{125}$ Idem. Ibidem. pp. 80-95.
} 
Maiorista; por outro se colocaram os deputados que se aliavam ao Regresso e que foram, em maioria, derrotados nas eleições para a legislatura de 1842. Sendo assim, o debate parlamentar acerca das "eleições do cacete" se deu a partir da divisão dos deputados em dois partidos definidos a partir da disputa eleitoral de finais de 1840: maioristas e regressistas. Proveniente de concepções e alianças políticas diversas, ${ }^{126} \mathrm{o}$ racha entre estes dois grupos - que num determinado momento, entre as décadas de 1840 e 1850, passaram a ser denominados liberal e conservador - se explicitou quando estiveram frente a frente na disputa pelo voto dos cidadãos brasileiros.

Antes mesmo da reunião da Assembléia em 1841, no dia 23 de março, D. Pedro II devolveu aos regressistas o Poder Executivo que lhes havia sido retirado pelo Golpe da Maioridade. A presença dos defensores do Regresso no ministério contribuiu muito para a crítica ao processo eleitoral conduzido pelos maioristas; entretanto, o divórcio entre os dois partidos na esfera parlamentar teve como combustível um grupo significativo de petições que, entre o final de 1840 e o início de 1841 (ou seja, antes mesmo da troca de ministérios), chegou à Câmara dos Deputados. Estas petições geraram um quente debate na legislatura de 1841; o dia 12 de maio, quando algumas delas foram apresentadas aos deputados, marcou o início da celeuma. O deputado da Paraíba Silvino Elvídio Carneiro da Cunha, aliado dos regressistas, foi o portador de duas petições vindas do Rio Grande do Norte. Denominando-se habitantes da freguesia de São João Batista da vila de Assú, um número indefinido de cidadãos se queixava aos representantes da nação contra a interferência ilegal do poder provincial sobre as eleições locais. O texto da petição de 1841 abria-se assim:

quando qualquer dos Poderes Políticos arroga a si atribuições que lhe não competem, desaparece a harmonia dos Poderes, perturba-se a ordem pública e os cidadãos não podem gozar das garantias constitucionais porque na divisão e harmonia dos Poderes Políticos é que está baseado o princípio conservador dos Direitos do Cidadão e o mais seguro meio de fazer efetivas as garantias que a Constituição lhes oferece.

A Assembléia Provincial, segundo relato dos peticionários, havia ilegalmente anulado as eleições para vereadores e juiz de paz procedidas naquela freguesia; fato este que os revoltara, pois, acreditavam eles, os representantes provinciais não podiam tomar conhecimento de eleições, as quais se regulavam por leis gerais. Explicavam ainda os habitantes de São João Batista que no dia da eleição não houve acordo entre dois

\footnotetext{
${ }^{126}$ Sobre as divergências políticas nascidas do seio dos liberais moderados, consultar: Miriam Dolhnikoff. O Pacto Imperial. Op. Cit. pp. 81-154.
} 
membros da mesa eleitoral - o pároco (partidário do sul) e o juiz de paz (partidário do norte) - quanto à escolha dos escrutinadores; assim sendo, o pároco se retirou sem deixar substituto e, por isso, a mesa chamou o único sacerdote que existia no lugar. Por não ter o convocado comparecido, chamou-se um homem bom, de acordo com o que mandava o Artigo 24 do Código de Processo Criminal. Tranqüilamente as eleições seguiram, tendo sido recebidas 456 cédulas, deixando de votar apenas 132 votantes.

Mas, representando aquele pequeno número de descontentes contra as referidas eleições à Assembléia Provincial, esta as anula por um simples parecer de comissão. Mas como assim não havia de acontecer se a maioria dos membros da Assembléia Provincial se declara chefes do partido do sul? Partido que se compõe dos anarquistas que assassinaram o Exmo. presidente antecessor do atual.

Frente ao que consideravam uma injustificável parcialidade, os peticionários recorreram ao presidente da província para que não sancionasse a resolução da Assembléia; mas seu pedido foi ignorado. Não obstante tudo o que se passara nas eleições municipais, no dia marcado para as eleições para Assembléia Provincial foi nomeado para presidi-las o juiz de paz José da Fonseca Silva, um suplente denunciado por responsabilidade em dois processos. O nomeado, ao constatar, porém,

\begin{abstract}
que não poderia mais presidir as eleições porque o povo se oporia aceso em ira, ordena que a Tropa que ali se achava postada às suas ordens faça fogo sobre o Povo e, sendo prontamente obedecido, rompe o fogo, todos se atemorizam, morrem dois baleados dentro da igreja, outros aparecem feridos, as portas da igreja, os altares e até as imagens dos santos são crivados de balas, corre o povo espavorido, foge por entre o fogo e desaparece; então aquele juiz de paz, temendo a reação, despreza a igreja e escolhendo a casa da câmara como lugar mais seguro, reúne-se com o pároco e com a gente de seu partido manda por a vila em [ilegível] e tomar as estradas, e é deste modo que se procedem as novas eleições, nas quais não votou a maior parte do Povo por ter sido dispersa à força das armas.
\end{abstract}

Concluíam os peticionários que "tudo isto se teria evitado se a Assembléia Provincial não tivesse anulado as primeiras eleições e nem mesmo havia motivo para anular-se.” Acreditavam eles que, mesmo se alguma nulidade tivesse ocorrido no pleito municipal, a Assembléia não tinha poder para anulá-lo pois o objeto estava fora de sua competência: foi sua atuação ilegítima que causou desordem e mortes na freguesia de São João Batista. Fechava-se assim o texto da petição:

Augustos e Digníssimos Senhores Representantes da Nação, se não for mantido o equilíbrio dos elementos dos Poderes Políticos necessariamente se hão de aumentar as funestas conseqüências que nascem da desarmonia e, em breve, aparecerá a anarquia em todos os pontos daquela província. É tempo de se fazer desaparecer a confusão 
desses Poderes, e os suplicantes esperam de vossas luzes a revogação daquele parecer de comissão e providências que evitem tão horrorosas cenas. ${ }^{127}$

O povo da freguesia não aceitaria mais os desmandos da facção minoritária e truculenta, apoiada pela Assembléia e pelo presidente da província. Caso os representantes da nação quisessem evitar incidentes mais graves do que os que já haviam ocorrido, deveriam tomar providências para que o processo eleitoral fosse feito em conformidade com a sagrada letra da Constituição. De acordo com a abertura da petição, "a harmonia dos Poderes" e "a ordem pública" estariam ameaçadas caso eventos como os do Rio Grande do Norte continuassem a se repetir no Império.

A outra petição apresentada por Elvídio Carneiro da Cunha à Câmara vinha assinada por 186 habitantes da freguesia de Campo Grande da vila da Princesa, da mesma província do Rio Grande do Norte. O documento abria-se de modo enfático:

fundados no direito de petição que lhes garante a Constituição do Império, persuadidos de que as Assembléias Provinciais não podem e nem devem tomar conhecimento de objetos que estão fora dos limites que lhes foram prescritos pelo Ato Adicional e confiados na prudência e sabedoria que sempre preside as vossas deliberações, vêm representar-vos contra o parecer da comissão da Assembléia Provincial do Rio Grande do Norte que anulou as eleições de juiz de paz e vereadores procedidas na sobredita freguesia.

Em data próxima às eleições, havia sido divulgado que o partido do sul pretendia estorvar as eleições, pois sabia já que o partido do norte seria vitorioso. Os partidários do sul, explicavam os peticionários, haviam sido responsáveis já pelo assassinato de um presidente provincial e eram verdadeiros anarquistas; os partidários do norte, ao contrário, eram os defensores da legalidade na província. No dia da eleição municipal, formada a mesa eleitoral em comum acordo por parte dos dois partidos e recebidos os votos, apareceu João da Fonseca Silva, juiz de paz habitante de outra freguesia, com procuração para entregar 46 cédulas. Depois dele, apareceram ainda muitos outros procuradores com grossos maços de cédula e, assim, instaurou-se o conflito: os forasteiros insultavam o juiz de paz local por querer fazer oposição à entrega; um dos membros da mesa eleitoral recebia quantas cédulas se lhe apresentassem; o juiz de paz não deixava de se opor veementemente; e, finalmente, o pároco, para evitar motins, ordenou que todas as cédulas fossem recebidas para que depois passassem por apuração.

\footnotetext{
${ }^{127}$ Petição dos habitantes da freguesia de São João Batista da vila de Assú. 12 de maio de 1841. Centro de Documentação e Informação. Arquivo da Câmara dos Deputados. Brasília. Consultado em fevereiro de 2009.
} 
Procede-se a apuração e principiando-se a apurar as cédulas que foram entregues por procuradores dentro de cartas fechadas e tratando-se de se excluir algumas por aparecerem as pessoas a quem eram atribuídas e negarem assinatura, aparecem vozerias e ataques ao juiz de paz [local] e pároco, homens armados apresentam-se à porta da igreja; aumenta-se o motim, gritam em altas vozes que é tempo de acometerse; levanta-se o pároco e procura acomodar os amotinados, e não podendo conseguir, retira-se, e o mesmo fazem alguns membros da mesa.

O juiz de paz local, após ter fechado a urna, levou-a para sua casa e logo avisou ao presidente da província do ocorrido. Este, por sua vez, ordenou a apuração.

Não contentes os partidários do sul com o resultado das eleições, dirigem à Assembléia Provincial uma representação cheia de falsidades e de ataques aos do partido contrário, e para completarem o número de 74 assinaturas servem-se de menores e fingem assinaturas de pessoas que se achavam ausentes em outras províncias; mas a Assembléia Provincial, arrogando a si atribuições que lhe não competiam, anulou as eleições por um parecer de comissão.

Tendo a Assembléia do Rio Grande do Norte aceitado os argumentos dos partidários do sul, foi designado um novo dia para se refazer as eleições.

Nesse dia apodera-se da igreja um ajuntamento ilícito composto de um $5^{\circ}$ juiz de paz e processado, de tropa e gente armada. Quer o povo desbaratar aquele ajuntamento; mas o $\left[1^{\circ}\right]$ juiz de paz e o pároco, temendo que houvesse mortandade no templo sagrado, procuram conter o povo, o que só puderam conseguir designando uma casa para nela proceder às eleições.

Para se evitar o choque frontal entre as facções inimigas, diziam os peticionários, foram feitas duas eleições em Campo Grande: uma delas, observando todas as solenidades, ocorreu na casa escolhida pelo juiz de paz e pelo pároco; a outra, ilegal, foi feita pelo ajuntamento que se apossara da igreja. A câmara municipal, em flagrante injustiça contra o povo da freguesia, aceitou o resultado obtido pelo ajuntamento ilícito: “e quem jamais pensaria que essa ilegal resolução tomada pela câmara fosse aprovada como foi pelo Exmo. presidente da província? Mas assim convinha para conseguir ser o deputado geral da província que tanto ambicionava."

Todas as irregularidades haviam sido provocadas, acreditavam os peticionários, pela ação da Assembléia Provincial que, ultrapassando suas atribuições legais, anulara o resultado das primeiras eleições. Por fim, os 186 habitantes da freguesia de Campo Grande expunham suas conclusões ao corpo legislativo nacional:

Augustos e Digníssimos Senhores Representantes da Nação, é no princípio que se deve prevenir as funestas conseqüências que se podem seguir de semelhantes excessos, se se consentir que as Assembléias possam decidir sobre a validade das eleições, que se 
regulam por leis gerais, não haverão eleições em que os cabalistas não façam motins e não haverá cidadão pacífico que se anime a comparecer nas eleições temendo as desordens e anarquia; esperam portanto os suplicantes da vossa prudência e sabedoria que tomando em consideração o expedido, seja extirpado aquele funesto abuso, revogando-se o parecer da comissão, para ficar em vigor as eleições que ele anulou. ${ }^{128}$

Ambas as petições do Rio Grande do Norte tratavam de eleições locais. Porém, a gravidade das acusações que traziam transcendia o seu âmbito: os abusos praticados pela Assembléia, pelos juízes de paz, pelo presidente de província e por seus protegidos do partido do sul iam contra, no dizer dos peticionários de São João Batista, os "Direitos do Cidadão" e "as garantias que a Constituição lhes oferece". O presidente da província na oportunidade era o goiano D. Manoel de Assis Mascarenhas; ele ocupava o cargo desde 1837, época em que os regressistas estavam no poder, e, diante da oportunidade que surgira em 1840, autorizou os abusos do partido do sul - majoritário na Assembléia Legislativa - por querer "conseguir ser o deputado geral da província". Os abusos durante as eleições para vereadores, juízes de paz e deputados provinciais, entendiam os peticionários, estavam relacionados à tentativa de se controlar a máquina eleitoral da província e de fazer eleger para a Assembléia nacional os aliados do partido do sul. Se tolerados, abusos como aqueles, no entender dos peticionários de Campo Grande, teriam resultados trágicos para a legitimidade do processo de escolha dos representantes da nação: as eleições gerais, dominadas pelos "cabalistas" vitoriosos no pleito local, se transformariam em conflitos sangrentos em que o "cidadão pacífico" não teria qualquer interesse em participar. Ambos os documentos apontavam para o risco que conflitos facciosos representavam para a ordem política no Rio Grande do Norte; contudo, não deixavam de lembrar os representantes da nação que daqueles abusos também padecia o equilíbrio dos poderes que se queria consolidar no Império.

Elvídio Carneiro da Cunha, após entregar as duas petições à comissão de constituição e poderes, requeria do governo informações sobre "a soma despendida pelos presidentes da Paraíba, do Rio Grande do Norte e do Ceará com as eleições dos deputados gerais, juízes de paz e câmaras municipais." ${ }^{129}$ As acusações sobre um abuso local, colocadas pelos peticionários das freguesias de Campo Grande e São João Batista, transformavam-se, então, num problema nacional. Sendo os presidentes de província

\footnotetext{
${ }^{128}$ Petição dos habitantes da freguesia do Campo Grande da vila da Princesa. 12 de maio de 1841. Centro de Documentação e Informação. Arquivo da Câmara dos Deputados. Brasília. Consultado em fevereiro de 2009.

${ }^{129}$ Anais da Câmara dos Deputados. 12 de maio de 1841. p. 63.
} 
apontados pelo ministério, sua intervenção ilegal no pleito trazia um grave problema de ordem geral. O deputado justificava seu requerimento: "o orador diz que lhe consta, por pessoas do Ceará e do Rio Grande do Norte, que, com efeito, se fizeram tais despesas com eleições, por isso que se empregou a tropa para se fazerem tais eleições, e a tropa nunca marcha sem que se façam despesas." ${ }^{130} \mathrm{O}$ regressista paraibano dava a entender que os acontecimentos relatados nas petições haviam sido encorajados pelo poder central - mais especificamente, pelo Gabinete Maiorista.

O deputado cearense Carlos Augusto Peixoto de Alencar, aliado dos maioristas e primo do senador Alencar, tentando esvaziar a polêmica aberta pela apresentação das petições, respondeu a Elvídio:

na província do Rio Grande do Norte (surpreende-me como o nobre deputado se dirige àquele nobre presidente) houve um pequeno barulho, mas foi por causa das eleições para juízes de paz, e não para deputados: e um pequeno movimento seria motivo para o excesso de despesa que o nobre deputado alega? No Ceará apareceu uma comoção na província; e então, porque foi necessário fazer despesa para sufocar a rebelião, segue-se logo que seria para eleições? ${ }^{131}$

Com o intuito de defender o Gabinete Maiorista, o deputado pelo Ceará lembrava que D. Manoel havia sido apontado pelos próprios regressistas como presidente do Rio Grande do Norte e que, na sua província, o movimento de tropas ocorrera devido uma rebelião e não com fins eleitoreiros. Honório Hermeto Carneiro Leão, líder do Regresso e deputado por Minas Gerais, logo compreendeu a estratégia de Peixoto de Alencar e apontou que a rebelião no Ceará poderia ter sido um fato provocado exatamente pelos fraudadores de eleições:

podiam-se, por exemplo, duplicar os movimentos de tropas, adiaremse continuamente a primeira, segunda e terceira vez os dias marcados para eleições (apoiados), até o ponto de levar a população a uma irritação tal que aparecesse uma sedição ou uma rebelião, e então sem dúvida o governo, qualquer que ele fosse, tinha obrigação de repelir e sufocar essa rebelião; isso custaria muitos e diversos movimentos de tropas; essas despesas não estariam mencionadas debaixo do título ou rubrica - despesas para eleições - mas sim debaixo da rubrica despesas com a tropa para sufocar a sedição ou rebelião. ${ }^{132}$

Carneiro Leão aconselhou o autor do requerimento a rever sua tática já que seria impossível comprovar a compressão eleitoral, no caso do Ceará, apenas a partir das despesas com a movimentação das tropas. Elvídio Carneiro da Cunha rapidamente

\footnotetext{
${ }^{130}$ Ibidem. p. 64.

131 Ibidem. p. 64.

${ }^{132}$ Ibidem. p. 65.
} 
compreendeu a argumentação do seu aliado mineiro e, retirando seu requerimento, reafirmou a ameaça contra os fraudadores:

eu peço licença à Câmara para retirar o meu requerimento; em tempo competente farei outro, e então provarei que na Paraíba e no Ceará foram as tropas fazer eleições, assim como no Rio Grande do Norte, como se depreende das representações que mandei à mesa. Na minha província marcharam tropas para se fazerem as eleições em muitas vilas, não só para deputados gerais, mas também para câmaras municipais e juízes de paz; e as eleições foram feitas à ponta de baionetas; marcharam tropas sem haver rebelião nem comoção popular; e posso afirmar ao nobre deputado pelo Ceará que a revolução que houve nessa província foi causada pelos atos arbitrários de seu ilustre primo, o causador de todas as desgraças que têm assolado o Ceará. ${ }^{133}$

O acusado era José Martiniano Pereira de Alencar, senador desde 1832, presidente da província do Ceará nomeado pelo Gabinete Maiorista e uma das mais importantes lideranças anti-regressistas. Segundo revelava o próprio Carneiro Leão, o senador Alencar havia manejado suas prerrogativas como presidente de província para levá-la à rebelião e, depois de ser declarado estado de sítio, proceder ao seu bel prazer às eleições:

Senhores, não serei eu jamais que aprove a imprudência desses homens que recorrem às comoções populares, aos debates das ruas e às armas, em vez de recorrerem aos meios legais de obterem a reta administração da justiça que o sistema representativo tem por fim estabelecer para todos os cidadãos: o recurso às armas é próprio mais para um povo bárbaro do que para um povo que se quer mostrar digno de gozar o sistema representativo. Mas, Senhores, não podendo desculpar jamais aqueles que são assaz imprudentes e não têm sofrimento para esperar melhor época de pelos meios legais fazer sobressair sua justiça, não posso deixar de conhecer algumas vezes provocações por parte dos governantes: se os governantes têm um fim iníquo, se os governantes têm por fim dirigir as eleições segundo as vistas do governo, e não do país, tenham embora o direito de mandar prender aqueles que se tornaram criminosos e dignos de castigo, mas não se julguem isentos de toda imputação que sobre eles deve cair pelo seu procedimento provocador. O Sr. senador Alencar armou uma opinião, armou gente para debelar outros homens; atacou uma tipografia que existia naquela província, como consta de um jornal, não da oposição, mas do governo, que aqui está. ${ }^{134}$

A intervenção ilegal do governo nas eleições havia sido generalizada. Esta tese, defendida em 1841 pelos inimigos dos maioristas, se comprovava por meio das petições apresentadas por Elvídio e pelos fatos relatados por Carneiro Leão. O senador Alencar, líderes do partido maiorista, utilizara-se de capangas para fazer deputados dóceis ao

\footnotetext{
${ }^{133}$ Ibidem. p. 65.

${ }^{134}$ Anais da Câmara dos Deputados. 14 de maio de 1841. pp. 113-114.
} 
Executivo. O deputado regressista demonstrava como este procedimento subvertia o regime representativo, tirando a disputa da esfera legal para transformá-la numa guerra bárbara. Ao provocar os cidadãos cearenses, levando-os ao desespero e à rebelião, o presidente da província conseguira aterrá-los, prende-los e fazê-los fugir. Já seria de se esperar tal atitude, dizia Carneiro Leão, "quando o Sr. senador Alencar se aventurava mesmo a dizer que as eleições deviam ser feitas segundo as vistas do governo." Alencar se comportara como chefe de facção e não como uma autoridade de um regime constitucional. Os abusos ocorreram por toda a parte, inclusive na Corte, e o Gabinete Maiorista, dizia Carneiro Leão, nada fez para impedi-los.

\begin{abstract}
Antes de terminar o meu discurso, não devo deixar de rememorar muitos abusos que se praticaram à face do governo nesta Corte, que mostram que os Srs. ex-ministros não deram providências para que os cidadãos votassem com liberdade. Sabia-se que havia homens que alguém considera inimigos, e que como tais deviam ser excluídos das urnas; sabia-se que grupos armados de cacetes nas portas das freguesias impediam que os cidadãos fossem exercer o direito que a Constituição lhes confere. A polícia teve denúncias de casas em que grupos armados se reuniam; a polícia desmanchou todas as reuniões dos adversários, mas não as casas em que se reuniam os grupos em que eram coniventes os homens alistados nos arsenais e empregados nas obras públicas. Avançarei mais: o governo entrou nas eleições, decidiu questões de mesas, consentiu que agentes seus subalternos fossem à nau $D$. Pedro Segundo, onde está a academia de guardasmarinha, e exigissem listas de acadêmicos, ainda mesmo de 12 anos, de grumetes, despenseiro e até de estrangeiros. ${ }^{136}$
\end{abstract}

A discussão iniciada com a apresentação das petições do Rio Grande do Norte encaminhara-se para a crítica de todo o processo eleitoral do final de 1840 . O Gabinete Maiorista, que então estava no poder, era frontalmente atacado pelos aliados do gabinete regressista recém-empossado, o gabinete de 23 de março. O debate se dava entre interesses partidários que se opunham; entretanto, algo mais estava em pauta: era a própria legitimidade do regime representativo no Brasil que estava sendo discutida naquele ano de 1841 quando as acusações contra a intervenção eleitoral dos maioristas eram levantadas.

Mesmo que o cearense Peixoto de Alencar respondesse imediatamente às acusações proferidas por Carneiro Leão contra seu primo, os fatos apresentados pelos seus adversários desmentiam-no. Assim, Francisco de Souza Martins, deputado pelo Piauí e aliado dos regressistas, leu durante um de seus discursos quatro petições vindas

\footnotetext{
${ }^{135}$ Ibidem. p. 115.

${ }^{136}$ Ibidem. p. 116.
} 
do Ceará que tratavam de abusos cometidos pelo presidente Alencar e por seus aliados. Dentre os injustificáveis atos do maiorista cearense estava a demissão sem explicação de uma multidão de empregados - "agentes do correio, empregados da tesouraria, oficiais da Guarda Nacional etc.; isto dentro de oito dias." Antes da chegada de Alencar, fora mandado para lá um "precursor para aplainar as dificuldades que podia encontrar o presidente nomeado," assim, os seus possíveis adversários políticos "foram suspensos, e logo metidos em processo." Após a chegada do senador maiorista, as leis provinciais foram todas desrespeitadas, diversos processos foram instaurados, cinco homens honrados foram presos por mais de sessenta dias e muitos oficiais militares foram removidos de seus lugares. ${ }^{137}$ Para demonstrar mais claramente o desrespeito do presidente do Ceará aos princípios constitucionais, Souza Martins apresentava à Câmara uma valiosa prova dos abusos - um relato a respeito do ataque promovido pelo presidente a uma importante tipografia cearense:

vou ler a representação de 70 pessoas respeitáveis do Ceará a respeito deste fato, nela vem assinado até o dono da casa, o Sr. Dr. Miguel Fernandes Vieira, juiz de direito da comarca de Sobral e presidente da Assembléia Provincial no tempo em que principiou os seus trabalhos. ${ }^{138}$

A petição (que não foi transcrita integralmente nos Anais e nem pôde ser encontrada no Arquivo da Câmara), segundo Souza Martins, trazia um retrato perfeito dos desmandos de Alencar no Ceará. O seguinte artigo, publicado pelo Popular, jornal de propriedade do Dr. Miguel, estava anexado à petição e, de acordo com o deputado piauiense, havia sido a motivação única para a demonstração de força dos capangas do presidente que, às quatro horas da madrugada, quebraram a tipografia:

\section{O Sr. Alencar sem rebuço}

Tem o Sr. Alencar empregado quanto há de arbitrário, pérfido e indigno para intimidar os pacíficos habitantes desta província, afim de lhes tolher a liberdade de votar e vencer S. Ex. nas próximas eleições, a cujo efeito nada poupa para afinal mostrar-se vitorioso na Corte, fazendo acreditar ser ele o senhor absoluto e exclusivo desta parte do Brasil. O fato seguinte é prova de nossa asserção.

Inventaram os satélites do Sr. Alencar, ou récua do Ceará, que o distinto major da Guarda Nacional de Marangape, Ignácio Pinto de Almeida e Castro, aí se achava reunindo gente contra o governo, e sem demora o nobre senador ordenou que ele se lhe apresentasse em palácio, o que cumpriu o Sr. Almeida, que chegando a esta cidade foi imediatamente falar ao nobre senador. Este, enquanto estava só, o tratou bem. É qualidade indispensável do déspota o ser covarde. Mas

${ }^{137}$ Anais da Câmara dos Deputados. 21 de maio de 1841. pp. 194-196.
${ }^{138}$ Ibidem. p. 203. 
apenas se viu cercado de sua guarda de honra composta dos Castro et reliqua, que o olham como seu verdadeiro e cego instrumento, ele deixou a urbanidade com que tinha a princípio tratado ao Sr. Almeida e começou, sem razão, a repreende-lo e insultá-lo com a maior grosseria; e porque este se defendeu, e a alguns amigos igualmente caluniados pelo nobre senador, the dirigiu as seguintes e insultuosas palavras, só dignas do déspota que hoje o Ceará suporta no leme de sua administração: - "Diabo, diabos, lado do diabo, oposição do inferno; hei de reduzi-los a pó, hei de esmagá-los, hei de vencer as eleições a ferro e a fogo, não admitirei nem listas; hei de mostrar-lhes que eleições só serão pro forma feitas, pois os deputados serão os que eu tenho designado; hei de perseguir a todos que quiserem favorecer os meus inimigos. Estou certo que me desacreditarão na Corte, onde prometi que o Ceará me aceitaria de bom grado e sem a menor perturbação: porém, como o contrário se tem visto e é já sabido, hei de tomar a mais cruel vingança, nada pouparei, destruirei suas fazendas, oprimi-los-ei... etc."

Desta sorte patenteou o Sr. Alencar a perfídia que domina seu malvado coração; desta sorte nos justifica e dá força ao que sempre temos dito dele.

Acautelai-vos, cearenses, das insídias que vos são preparadas; lembrai-vos que tendes uma Constituição livre, hoje pisada sem escrúpulo pelo Sr. Alencar. Cuidado, pois vossa liberdade, honra, propriedade e vida, tudo está ameaçado. Mostrai valor e constância e não consintais jamais que vosso irmão Caim roube o que tendes de mais precioso. ${ }^{139}$

Consta nos Anais da Câmara que Peixoto de Alencar afirmou diversas vezes que tal relato era falso e chegou mesmo a protestar perante o presidente da Câmara. Mesmo Souza Martins admitiu que o retrato traçado pelo Popular poderia ser um tanto exagerado: "não digo ao nobre deputado que é verdade o que esta folha diz; (...) concordo em que o artigo é atacante, mas não são estas as maneiras por que se evitam os abusos da liberdade de imprensa. $" 140$ Nada justificava o covarde ataque a uma tipografia patrocinado pelo presidente provincial, suposto protetor da ordem e da liberdade. Após ler o resto da petição do dono da tipografia e de "outras pessoas da capital da província, negociantes respeitáveis, como os Srs. Mendes e irmãos”, o deputado pelo Piauí concluía seu discurso:

pela leitura deste documento, a Câmara pouco mais ou menos pode conhecer qual foi o espírito da presidência do Sr. Alencar. Creio que não se pode fugir à evidência dos fatos; eles provam que o espírito foi vencer as eleições à força de todos sacrifícios que se pudessem fazer; empregar a força, despender os dinheiros públicos, pôr em comoção a província toda, conquanto que se levasse à vitória nas eleições. (Apoiados.) E, Senhores, pode-se aprovar semelhante administração? ${ }^{141}$

\footnotetext{
${ }^{139}$ Ibidem. p. 203.

140 Ibidem. p. 203.

${ }^{141}$ Ibidem. pp. 203-204.
} 
As petições de cidadãos se queixando dos abusos eleitorais estavam no centro do debate acerca da legitimidade do Poder Legislativo no Império que ocorria na Câmara em 1841. O relato nelas contido servia aos deputados como comprovação para seus argumentos contra os maioristas. Naquele momento em que se buscava estabilizar no Brasil o regime representativo, a voz dos representados ganhava um valor inestimável. As petições funcionavam como instrumentos de disputas políticas justamente porque estavam em consonância com os princípios do regime. A representação legítima do povo brasileiro só seria possível caso o seu direito de escolha fosse respeitado; como o próprio governo interferira no processo eleitoral de forma irregular, os deputados eleitos para a legislatura que se iniciaria em 1842 não se constituam, de fato, como legítimos representantes da nação. Baseados nos princípios que fundamentavam a política no Império e também no relato dos cidadãos brasileiros acerca das fraudes e violências, os regressistas encontravam forças para deslegitimar as eleições conduzidas pelos seus adversários.

Também as eleições na Paraíba ganharam destaque dentro do debate parlamentar a partir de uma petição. O deputado Elvídio Carneiro da Cunha, o mesmo que havia apresentado as petições do Rio Grande do Norte e desferido os primeiros ataques contra o senador Alencar, requereu do governo a correspondência oficial do ex-presidente da Paraíba apontado pelo Gabinete Maiorista, Francisco Xavier Monteiro da Franca: "quero apresentar fatos" - justificava o deputado - "afim de que por eles se veja que as eleições da minha província foram feitas com força armada." ${ }^{142} \mathrm{O}$ deputado paraibano tinha por base de sua acusação uma petição datada de dezembro de 1840 , enviada à Câmara por José de Holanda Cavalcanti, juiz de paz da vila do Pilar. O documento continha denúncias contra os abusos que Monteiro da Franca patrocinara durante as eleições na Paraíba: “com a mais escandalosa violência e arbitrariedade," escrevia o peticionário, o presidente da província decretara a sua suspensão sem ter procedido à necessária audiência que a lei exigia e sem que ele tivesse cometido um ato irregular sequer, já que havia um ano se encontrava doente. Continuava:

julgo do meu dever patentear-vos tão revoltante prepotência, para que vos digneis prestar-lhe a consideração que merece, visto que ela só teve por fim a execução de um dos planos da feroz conquista com que aquele Delegado do Governo tem barbaramente guerreado e oprimido nesta província o Poder Eleitoral para conseguir a todo custo uma votação favorável aos interesses de meia dúzia de facciosos e

${ }^{142}$ Anais da Câmara dos Deputados. 12 de junho de 1841. p. 491. 
aventureiros que infelizmente o dirigem em todos os seus atos, calcando aos pés a Constituição e as Leis e os princípios mais triviais da decência e da honestidade.

Não foi senão o desejo de sair vitorioso dessa vergonhosa conquista que o obrigou a seguir desde o dia de sua posse um sistema de administração inteiramente novo e inaudito e, sobretudo, infenso e hostil ao Trono de Sua Majestade Imperial, submetendo-se aos ditames de pessoas mal intencionadas e conhecidamente avessas à Monarquia e à união e integridade do Império, e pondo em prática todo o gênero de violências, perseguições e terrores contra maioria dos habitantes desta província, cujos sentimentos de ordem e adesão à Sagrada Pessoa de nosso Augusto Monarca deveriam necessariamente embargar-lhe o triunfo desejado.

O ataque empreendido por "meia dúzia de facciosos e aventureiros" ao direito dos cidadãos paraibanos representava, segundo Cavalcanti, um ataque à monarquia e à Constituição brasileiras. Relatava o peticionário que, logo depois da posse de Francisco Xavier Monteiro da Franca na Paraíba (em setembro de 1840, sob o Gabinete Maiorista), mais de duzentos empregados públicos foram substituídos por "homens façanhosos, turbulentos e amigos do crime" que, por sua vez, recebiam força armada com o fim de "subjugarem a ferro e fogo os colégios eleitorais, cometendo, à sombra dela, os maiores atentados e extorsões." Como alguns juízes de paz não se sujeitassem a semelhante opressão, foram todos imediatamente suspensos e substituídos por homens sem escrúpulos, que organizaram e presidiram as mesas paroquiais, levando a cabo o triunfo eleitoral do presidente opressor. O tamanho do abuso podia ser melhor percebido pelo fato de que, na vila do Pilar, não somente o peticionário mas os três suplentes imediatos haviam sido suspensos na véspera das eleições primárias. Diante de tamanha imoralidade, Cavalcanti fazia seu apelo:

Augustos e Digníssimos Senhores Representantes da Nação, testemunha ocular dos horríveis planos com que foram proximamente feitas nesta província as eleições de deputados, assim gerais como provinciais, para a seguinte legislatura, eu poderia certamente fazervos uma narração minuciosa dos vícios e ilegalidades que se cometeram em todos os colégios eleitorais por onde se provaria evidentemente a sua nulidade e não duvidaria mesmo demonstrar-vos que tais eleições, longe de se considerar como livre expressão da vontade da maioria dos habitantes da província, não foram senão os despojos de uma luta encarniçada, obtidas a ponta de baionetas. Porém, devendo limitar-me a uma simples exposição do que comigo se passou, esta mesma vos faço não tanto pela profunda mágoa da ofensa e ultraje com que foram gravemente feridos os meus direitos, senão também pelo justo ressentimento e indignação de que me acho possuído ao aspecto das maquinações e perfídias com que são atraiçoados os interesses do país por aqueles mesmos que deveriam elevá-lo ao fastígio da grandeza e prosperidade que a Providência the destinou. 
Dignai-vos, portanto, Senhores, acolher benignamente a minha franca e humilde voz, e já que só de vossas mãos hoje dependem os destinos da Pátria e a futura sorte dos vossos irmãos brasileiros, fazei, fazei por salvá-los do horroroso abismo que lhes preparam seus cruéis inimigos. ${ }^{143}$

O processo eleitoral na Paraíba, que deveria representar a livre escolha de cidadãos brasileiros, não passara de um ato de perversidade conduzido por aquele que deveria ser o primeiro a zelar pela ordem pública e pelas garantias constitucionais. Mais do que um ato isolado contra os habitantes de uma província, os abusos cometidos pelo presidente Monteiro da Franca representavam uma série de "maquinações e perfídias com que são atraiçoados os interesses do país"; ou seja, os atos do presidente maiorista eram representativos de um plano amplo de corrupção que colocava em risco a legitimidade do processo eleitoral no Império como um todo.

A queixa de José de Holanda Cavalcanti não era solitária: uma petição de outro juiz de paz da Paraíba, este da freguesia de Taipú, mostrava que a perversão de Monteiro da Franca não se resumira à vila do Pilar. Narrava Francisco Antonio Pereira que, ao se dirigir para a igreja matriz de Taipú para presidir a mesa paroquial instalada para o procedimento das eleições de eleitores, encontrou entre o povo o subprefeito João Coelho de Souza acompanhado de um grupo de gente armada. O subprefeito e seus capangas disseram que Pereira estava suspenso de suas funções de juiz de paz por ordem do presidente da província. Assumira seu lugar o segundo suplente, José Lins Cavalcanti, por ter sido também suspenso o primeiro substituto.

Não podendo, porém, entrar em dúvida que semelhante suspensão era ilegal e despida das formalidades necessárias para sua validade, visto não ter sido eu ouvido anteriormente, como era de lei julguei que não devia nem podia submeter-me a elas, não só por não me ser lícito obedecer a ordens ilegais escritas em cartas brancas, antecedentemente distribuídas com o nome de sua Excelência [o presidente da província], se não também por não convir aos interesses públicos, que em circunstâncias tais renunciasse eu os meus foros e garantias em favor de uma violência com que se pretendia usurpar os direitos eleitorais de meus co-paroquianos; tanto mais quanto se tinha tornado bem patente o particular interesse e obstinação com que sua Excelência o Sr. presidente da província, usando de todos os meios a seu alcance, talvez por insinuações sinistras de alguns espíritos inquietos e desorganizadores, que sobre ele exercem poderosa influência, pretendia, por fás ou por nefas, fazer que saíssem eleitos deputados os candidatos de sua escolha e afeição, para cujo fim, não lhe sendo suficiente o sistema de terror e o emprego da força de que lançou mão, pondo-se em movimento por todas as partes tropas

${ }^{143}$ Petição do juiz de paz da vila do Pilar. 22 de dezembro de 1840. Centro de Documentação e Informação. Arquivo da Câmara dos Deputados. Brasília. Consultado em fevereiro de 2009. 
aguerridas, havia sido decretada a minha suspensão, bem como de outros juízes de paz e suplentes, mandando se juramentar imediatos escolhidos de propósito que, de acordo com as mesas paroquiais por eles organizadas, promovessem o resultado desejado, embora cometessem os maiores escândalos e abusos, como infelizmente sucedeu em quase todos os Colégios eleitorais da província.

Tendo em vista o abuso inaceitável que vinha ocorrendo em sua província, o juiz de paz insistiu pelo exercício de seu cargo de presidente da mesa, tentando desvanecer as intenções criminosas do subprefeito por meio da justa razão e da moderação; neste empreendimento foi ajudado pelo pároco da freguesia e por todas as pessoas de maior graduação que ali estavam. Entretanto, refutando os apelos dos homens de bem, o subprefeito ameaçava usar a força e entre o povo crescia não pequena agitação e tumulto. As ameaças continuaram por longo tempo e os perigos foram crescendo até que um soldado do subprefeito disparou seu bacamarte em direção ao tenente-coronel Manoel Gomes da Silva, que por mera casualidade deixou de ser atingido. Desejando evitar derramamento de sangue, o pároco se retirou e o peticionário o seguiu; o povo, finalmente, se dispersou sem que se fizesse eleição alguma.

O presidente da província, ao ser avisado do ocorrido pela câmara municipal de Taipú, nada providenciou, deixando assim de marcar uma nova data para o pleito: desta forma se beneficiou, pois sabia que eleitos ali 19 eleitores desfavoráveis às suas pretensões poderia ver transtornados os seus planos. Continuava o juiz de paz Francisco Antonio Pereira:

entretanto sem lisonjear-me em tempo algum de haver desobedecido a ordens emanadas de meus legítimos superiores, aos quais muito desejo mostrar-me sempre submisso e obediente, julgo ter procedido em regra e segundo exige a dignidade de um cidadão respeitador das leis e das instituições de seu país, e posto que minha única profissão e gênero de vida sejam os trabalhos da agricultura, bem diversos e alheios da Política, todavia não podendo sofrer com indiferença a injustiça e afronta que se me fez e o desprezo com que foram tratados os meus co-paroquianos e sobretudo os escandalosos excessos e ilegalidades com que acabam de ser viciadas as eleições desta província e inteiramente falsificada a sua Representação, assim Geral, como provincial, tomei a liberdade de oferecer a vossa alta consideração e sabedoria esta sucinta e breve, porém fiel, exposição para que vos digneis providenciar sobre o acontecimento conforme reclamam os interesses da pátria, de cujos destinos sois depositários. $^{144}$

\footnotetext{
${ }^{144}$ Petição do juiz de paz da freguesia de Taipú. 24 de dezembro de 1840. Centro de Documentação e Informação. Arquivo da Câmara dos Deputados. Brasília. Consultado em fevereiro de 2009.
} 
Os juízes de paz que sofreram com os desmandos do presidente apontado pelos maioristas depositaram nos deputados gerais a esperança de reencontrar a justiça e garantir a verdade da representação. Essas iminências locais, distantes milhares de léguas da Corte, faziam uso do direito de petição com o fim de denunciar o comportamento faccioso daqueles que, incumbidos de manter a paz e de levar prosperidade às províncias, acabaram por difundir o ódio entre seus cidadãos.

Tendo em vista os relatos contidos nas petições, o deputado pernambucano Venâncio Henriques de Rezende apoiou o requerimento de Elvídio Carneiro da Cunha que pedia a correspondência do ex-presidente maiorista da Paraíba: "ora, um presidente de província que diz ao governo: as eleições se fizeram angelicalmente e o nosso partido triunfou, que quer dizer isto? Não sei que o governo e um presidente de província devam seguir outro partido que não seja a execução da lei." ${ }^{145}$ Segundo Henriques de Rezende, Monteiro da Franca não só cometera os abuso eleitorais, como também comemorara seu feito em ofício ao ministro maiorista Antônio Carlos: sendo assim, o exame da correspondência do presidente pela Câmara se justificava.

Antônio Carlos, iminente líder do Golpe da Maioridade e ministro do Império em 1840, era acusado por Henriques de Rezende de ser o articulador das "eleições do cacete". No ano de 1841 o político paulista ocupava um acento na Câmara dos Deputados e não pôde deixar de se defender perante as acusações proferidas pelo pernambucano:

não me oponho ao requerimento, venham todos os documentos que se pedem, mas ao que me oponho é a essa idéia emitida pelo nobre deputado de Pernambuco. Ainda que o ex-presidente da Paraíba dissesse - o nosso partido triunfou - nenhum tribunal do mundo o condenava por isso; um presidente tem como o nobre deputado, e como qualquer pessoa, o direito de ter um partido e de regozijar-se do triunfo dele; do que não tem direito é de influir por violência ou suborno para que esse partido ganhe. (...) O que eu entendo é que nenhum partido pode violar a lei, que nenhum pode empregar a violência, isso sim; mas querer que o governo não tenha um partido é coisa que na verdade me faz rir! ${ }^{146}$

O membro do clã dos Andradas rebatia as acusações de fraude a partir da idéia de que, num regime representativo, era normal que os homens públicos tivessem partidos e os defendessem sem, todavia, patrocinar violência e fraude. Diante desta colocação, o regressista Souza Martins respondeu ao ex-ministro:

\footnotetext{
${ }_{145}$ Anais da Câmara dos Deputados. 12 de junho de 1841. p. 491.

${ }^{146}$ Ibidem. p. 491.
} 
eu concordo em que os indivíduos que compõem a administração, tendo um partido como indivíduos, como empregados públicos são empregados da nação e na correspondência oficial não devem dizer o meu, o seu partido, etc. - Eu creio que o nobre ex-ministro, apesar de declarar que tinha um partido, na correspondência oficial que tivesse com esse ex-presidente não lhe havia dar ordens para que o seu partido vencesse, pois que em uma correspondência oficial não se admitem esses estilos; creio que a censura recai bem no ex-presidente [Monteiro da Franca]. O governo não deve falar em nome do partido, mas sim em nome da nação. ${ }^{147}$

O deputado pelo Piauí acusava Antônio Carlos de facciosismo, de não ter cumprido os fins exigidos por um regime que se baseava no interesse de toda a nação; condenava-o por ter apenas se interessado pela vitória de seu partido, permitindo que abusos fossem levados a cabo pelos presidentes provinciais nomeados pelo ministério. Iniciava-se, então, um dos mais importantes debates políticos do Império brasileiro, o debate acerca da influência do Poder Executivo sobre o processo eleitoral.

Diante da perspicaz argumentação de Antônio Carlos, um deputado pela Paraíba, José Maria Idelfonso Jacome da Veiga Pessoa, retomou as evidências sobre as atrocidades patrocinadas pelos agentes do Gabinete Maiorista. Segundo ele, o expresidente de sua província não só protegera seus partidários - o que seria justo - como também atacara de modo desleal os adversários valendo-se de um batalhão armado, o qual denominava "repúblicos". Baseado na petição do juiz de paz José de Holanda Cavalcanti, o deputado relembrava para os seus pares os tristes fatos ocorridos na Paraíba:

na vila do Pilar, Senhores, nunca violada, onde jamais foi possível entrar o germe da discórdia, mas não obstante isso o ex-presidente, o Sr. Franca, mandou o bem conhecido repúblico, que chegou ali na véspera da eleição, incumbido de suspender o juiz de paz, e com a demissão para o comandante do batalhão e outras autoridades. Esse homem, apenas chegou à vila do Pilar, procurou um sujeito que goza de tão pouca consideração e é tão mal visto que só sai algumas vezes de dia com muita cautela, instou com ele para que aceitasse ser juiz de paz porque era $5^{\circ}$ ou $6^{\circ}$ votado, e fez com que às 8 horas da noite prestasse juramento. ${ }^{148}$

Assim, concluía o representante paraibano, as eleições se deram segundo os desejos de Monteiro da Franca e contra a vontade dos pacíficos cidadãos daquela vila. Diferente foi o caso, porém, na vila de Taipú, conforme narrava a petição de Francisco Antonio Pereira e repetia diante dos representantes da nação o deputado Veiga Pessoa:

\footnotetext{
${ }^{147}$ Ibidem. p. 491.

${ }^{148}$ Ibidem. p. 497.
} 
nessa apareceu o povo pelas 9 horas do dia. Apareceu o vigário, o Sr. Jerônimo Cavalcanti, e o juiz de paz em exercício, o Sr. major Francisco Antonio Pereira; apareceu um suplente do sub-prefeito de encomenda, porque o legítimo não se quis apresentar para o que se queria, que era demitir o juiz de paz. (...) E quando se estava para formar a mesa presidida pelo outro juiz de paz e pelo vigário, que é sobrinho do Sr. José Lins, apresentou-se o Sr. José Lins trêmulo, assustado, dizendo: - eu estou determinado a cumprir o que mandou o Sr. presidente, tomando o lugar do juiz de paz que o Sr. Francisco Antonio está fazendo! (...) - O povo principiou a falar, houve muito sussurro e seguiu-se então a desordem. ${ }^{149}$

Além desses dois, Veiga Pessoa apresentou ainda outros relatos sobre os abusos patrocinados por Monteiro da Franca na Paraíba por ocasião das eleições. A partir das evidências, a sua conclusão era que o ex-presidente, com apoio da Assembléia Provincial e do ministério, cometera todo tipo de crime para garantir um resultado favorável para os maioristas nas eleições.

Demitiu a alguns oficiais, rebaixou outros, nomeou e demitiu todas as autoridades policiais, prefeitos, sub-prefeitos, comissários, juízes municipais etc.; em poucos dias eram já cinqüenta e tantas as remoções dos homens os mais probos daqueles que tinham conservado a província em paz e tranqüilidade! O presidente estava, é verdade, no seu direito, mas eu quisera que ele não atacasse como atacou os direitos do cidadão brasileiro na ocasião das eleições, eu entendo que foi um crime muito atroz! A Constituição diz aos cidadãos - vós podeis votar livremente conforme for sua vontade mas ali não se entendeu assim, caíram contra os cidadãos com armas, como se fossem bandos de cossacos. ${ }^{150}$

As substituições de agentes do poder - "autoridades policiais, prefeitos, subprefeitos, comissários, juízes municipais" - estiveram dentro da legalidade; entretanto, estes atos foram seguidos pelo injustificável desrespeito ao direito dos cidadãos brasileiros, pela violência e pela fraude. Na visão de peticionários e representantes, a atuação dos maioristas durante as eleições do final de 1840 significava uma mácula no regime representativo e um grave risco para a civilização do Império. Ainda mais enfático do que Veiga Pessoa ao traçar tal correlação foi Elvídio Carneiro da Cunha:

quanto a atrocidades devo dizer (...) que não só os presidentes, mas quaisquer delegados do governo que não cumprirem com a lei, que abusarem da confiança que neles se depositou para administrarem a justiça, e que assim promoverem revoluções ou comoções, cometem uma atrocidade. Ora, (...) meus outros colegas que não são meus correligionários políticos ainda não contestaram o fato de ter o expresidente da Paraíba mandado forças para vários colégios [eleitorais], do que resultou fazerem-se as eleições em muitas freguesias com as

${ }^{149}$ Ibidem. p. 497.
${ }_{150}$ Ibidem p. 493. 
igrejas cercadas de tropas, o que fez com que muitos párocos se retirassem e não quisessem fazer as eleições. $O$ ex-presidente da Paraíba, desconfiando que, se as eleições fossem livres, não triunfaria esse partido que, segundo dizia, era só o verdadeiro monarquista, mandou essas tropas, e daqui se vê que, havendo um partido maior, ele poderia também tomar as armas e ensangüentar a província. ${ }^{151}$

Dirigindo-se a Antônio Carlos, Elvídio dizia que o problema não estivera no fato dos ministros maioristas terem indicado gente sua para os cargos administrativos da Paraíba na época das eleições, mas no fato de seus agentes "promoverem revoluções ou comoções" transformando o processo eleitoral numa batalha entre facções inimigas. Ao invés de promoverem a justiça, os delegados do ministério haviam provocado indizíveis atrocidades no ano de 1840 . De acordo com a opinião que ganhava força na Câmara, as fraudes e as violências patrocinadas pelos agentes do Gabinete Maiorista se constituíam num crime que, a um só tempo, deslegitimava a escolha dos representantes da nação e instaurava no Império conflitos sangrentos que perigavam desaguar na erosão de toda a ordem nacional.

Apesar de toda essa discussão ter se dado em torno das eleições em províncias do norte do Império, foi de um lugar bem mais próximo à Corte que surgiram as evidências mais gritantes acerca das fraudes eleitorais levadas a cabo por agentes do poder central em 1840. O padre João Antunes Corrêa, deputado regressista de Minas Gerais, foi o primeiro a levantar suspeita sobre as eleições que tiveram lugar na sua província. Num tom irônico ele acusava: "na província de Minas Gerais e em outras províncias do Império a sublime teoria dos cacetes tem tido um espantoso crescimento!"152 Imediatamente, seu co-provinciano maiorista Teófilo Benedito Ottoni respondeu: "é falso". Diante da indignação de Ottoni, Antunes Corrêa pôs-se a explicar: "naquela província, Sr. presidente, têm-se cometido atentados inauditos, atentados horrorosos, que têm sobremaneira aterrado aqueles cidadãos que ainda almejam pela consolidação da Constituição e da monarquia constitucional." ${ }^{153}$ Ali mesmo, na mais povoada província do Império, a "teoria dos cacetes" tivera a maior efetividade. Só uma conclusão decorria daí: o ministério, em 1840, de fato, dera carta branca aos fraudadores. Concluía o acusador:

eu desejaria, se possível fosse, correr espesso véu sobre tais acontecimentos, porque, consignados eles na história parlamentar, serão um padrão de opróbrio para a nossa civilização, mas cumpre

${ }^{151}$ Anais da Câmara dos Deputados. 17 de junho de 1841. p. 578.

${ }_{153}^{152}$ Anais da Câmara dos Deputados. 28 de maio de 1841. p. 310.

${ }^{153}$ Ibidem. p. 310. 
manifestá-los: isto devo à minha província e ao Brasil inteiro. Eu não desconheço que o governo pode, por ocasião das eleições, desenvolver toda a atividade, procurando triunfar por todas as maneiras lícitas, mas o meio dos cacetes e dos punhais não pode ser admitido por maneira nenhuma. ${ }^{154}$

Mais uma vez retornava-se ao ponto colocado por Antônio Carlos: o ministério podia, sim, defender seus aliados políticos e obrar por seu triunfo eleitoral; todavia, não tinha o direito de sair da esfera da legalidade, fazendo uso de "dos cacetes e dos punhais". Antunes Corrêa apresentava evidências que comprovavam que, no final de 1840, as eleições haviam sido conduzidas pela fraude e pela violência. O regressista tinha em mãos relatos produzidos por cidadãos e autoridades de Minas Gerais que comprovavam que os agentes de poder maioristas haviam agido violentamente durante a disputa eleitoral com a finalidade de saírem vitoriosos.

Com data de elaboração de novembro de 1840, chegou à Câmara uma petição de Minas Gerais que se abria assim: "convencidos de ter sido injustamente privados de um direito constitucional, os abaixo assinados eleitores pela freguesia de Curmataí não podem deixar de levar à vossa presença seus queixumes." Os sete eleitores que assinavam a petição consideravam-se injustiçados, pois seus diplomas - obtidos a partir das eleições primárias em sua freguesia - haviam sido julgados nulos pela mesa paroquial de Diamantina, onde ocorrera a eleição para deputados gerais. Segundo os peticionários, os membros da mesa argumentaram que os seus diplomas continham apenas a assinatura do secretário da câmara municipal, o que supostamente não seria suficiente para comprovar sua autenticidade. Não obstante a presença ali em Diamantina do juiz de paz e do vigário de Curmataí, que atestavam a veracidade de sua eleição, a mesa fez com que eles se retirassem. Diante do exposto, pediam os peticionários providências aos representantes da nação contra um abuso como aquele levado a cabo pela mesa paroquial. ${ }^{155}$

Alguns membros da mesa paroquial de Diamantina também escreveram sua petição aos representantes da nação para denunciar os abusos que ali tiveram lugar. Segundo eles, nos arredores daquela importante cidade de Minas Gerais, dois partidos bem pronunciados disputavam a eleição para eleitores e era bem sabida a grande quantidade de punhais fabricados nos dias anteriores. O juiz de direito, chefe do partido do governo, que havia se retirado havia tempos da cidade, inesperadamente voltou,

\footnotetext{
${ }^{154}$ Ibidem. p. 311.

${ }^{155}$ Petição dos eleitores da freguesia de Curmataí. 16 de novembro de 1841. Centro de Documentação e Informação. Arquivo da Câmara dos Deputados. Brasília. Consultado em fevereiro de 2009.
} 
irritando a oposição e enchendo de orgulho seus partidários. Assim, toda a energia e prudência do juiz de paz tornaram-se ineficazes para assegurar a tranqüilidade pública ameaçada pela presença e pelos atos do juiz de direito, o qual, solicitando uma força considerável da Guarda Nacional, distribuiu pela cidade patrulhas a cavalo e a pé, transformando-a num campo de armas. Instalada a mesa e recebidos os votos, percebeuse que as cédulas - um total de 3078 - ultrapassavam em um terço o que havia sido apresentado nas eleições anteriores. A fraude levada a cabo pelo juiz de direito e seus comparsas era evidente:

no primeiro exame se observaram nomes de mendigos, africanos, de pessoas que não existiam e assinaturas de habitantes de comarcas diferentes; e contudo os homens do partido do governo alta e publicamente bradavam que o momento em que a mesa rasgasse a primeira lista seria o último da existência dos abaixo assinados.

Diante da clara má fé de alguns, o digno juiz de paz solicitou uma força de doze homens para proteger os cidadãos de bem. Contudo, quando divulgou a notícia de que começaria a rasgar as listas fraudadas
viu-se a Matriz recheada de governistas com o sobrolho carregado, ar sombrio e distraído: distribuiu-se cartuxame embalado pela Guarda Nacional havendo-se mandado marchar para a cidade uma companhia postada a quatro léguas em distância, sem que o juiz de paz soubesse de tais movimentos. Em presença mesmo das praças requisitadas pelo juiz de paz, uma patrulha do juiz de direito insultava com buscas à porta do templo os cidadãos supostos oposicionistas, sendo livre o trânsito aos do lado contrário, cujos punhais e pistolas eram trazidos com bem pouca cautela, quando uma só arma não se achou naqueles que eram tão insolentemente apalpados.

Nisso, um membro da mesa, ultrajado pelo estado de coação em que o juiz de direito tinha colocado a vila, se retirou, sendo acompanhado pelo membro escrutinador e pelo pároco. Foi então que

no meio do tumulto e vozeria que excitou a retirada dos abaixo
assinados, tropa armada e enviada de pronto (não sabemos por quem)
ocupou as avenidas da Matriz com as clavinas engatilhadas apontando
para dentro e impedindo a entrada e saída aos homens de oposição;
mas permitindo livre acesso aos contrários que corriam armados.

Com dificuldade se restabeleceu a ordem. O fatigado juiz de paz, a fim de mitigar a irritação dos ânimos, suspendeu as eleições. Não havia condições, concluíam os peticionários, de se proceder à escolha dos representantes da nação com tamanho alvoroço e com uma guerra prestes a estourar na cidade de Diamantina; guerra cujos 
provocadores haviam sido os governistas, supostamente encarregados de defensor a ordem e a legitimidade das eleições. ${ }^{156}$

Do mesmo mal diziam ter sofrido dois outros peticionários, membros (pároco e secretário) da mesa paroquial da cidade mineira do Serro. O acusado da vez era o juiz de paz que, assim como o juiz de direito de Diamantina, aliava-se ao Gabinete Maiorista. Entendiam os peticionários que era seu dever explicar aos representantes da nação as razões por que eles, devido à maneira insólita e abusiva pela qual ia se manobrando as eleições com a finalidade de se fazer vencer os governistas, haviam se retirado antes que seu sagrado dever fosse cumprido. Reunindo-se o povo da cidade para as eleições de eleitores, encontrou, assombrado, 31 praças armados do corpo policial na porta da igreja matriz a serviço do juiz de paz Joaquim Pereira de Queiroz que, dizia-se, iria impor à mesa aquilo lhe fosse de maior agrado. Assim, quando uma parte do povo agiu energicamente, ainda que dentro da ordem, para impedir que Teófilo Benedito Ottoni e Francisco José de Vasconcellos Lessa (ambos líderes políticos em Minas e aliados do Gabinete Maiorista) tomassem lugar à mesa, aquela força invadiu e profanou o sagrado recinto com espadas desembainhadas e baionetas, incutindo o terror nos cidadãos pacíficos. Talvez, especulavam os peticionários, cenas bem lutuosas tivessem acontecido se alguns cidadãos, mesmo ultrajados, não tivessem usado de sua honrosa influência para fazer com que o povo aceitasse a mesa, mesmo sem que aqueles dois merecessem lugares nela.

Dominando a mesa, passaram Ottoni e Lessa a proceder de maneira incongruente, inconstante, ilegal e parcial em favor da "turbulenta minoria" que apoiava os maioristas. Recebidas as listas, o juiz de paz decidiu que somente se apurariam aquelas que fossem dos votantes inscritos na eleição para vereadores do Serro, ocorrida havia dois meses; decidiu ainda, incoerentemente, que seriam apuradas todas as listas enviadas pelos juízes de paz de Itambé e São Gonçalo, ainda que não seguissem o mesmo critério. Deliberou também que os votos daqueles que não estivesse inscritos e nem fossem de Itambé ou São Gonçalo só seriam contados quando os votantes fossem pessoas conhecidas da mesa. Tendo por base a Constituição brasileira, os cidadãos presentes se opuseram a tão estranha e revoltante prática; mas de nada adiantou sua resistência. Com a finalidade de vencer os membros da mesa que agiam pela legalidade do processo eleitoral (dentre os quais estavam os peticionários), o juiz de paz se arrogou

${ }^{156}$ Petição da mesa paroquial de Diamantina. 03 de novembro de 1840. Centro de Documentação e Informação. Arquivo da Câmara dos Deputados. Brasília. Consultado em fevereiro de 2009. 
dois votos, um como membro da mesa e outro como juiz de paz, para junto de Lessa e Ottoni constituir maioria absoluta. Assim, toda a dúvida que surgiu foi decidida em favor dos governistas, apesar do escândalo e da notória arbitrariedade que se mostrava:

se entrava em dúvida se um votante era ou não morador da freguesia, em vão atestava o pároco ser ou não seu freguês, sua asserção nada valia, e ficando empatada a questão, o juiz de paz a desempatava com desprezo da asseveração do pároco, sempre que o interesse de seu partido assim o exigia; e deste modo centenas de listas de cidadãos, a quem sobejava a capacidade que a lei exige para votar, foram rasgadas, bem como apuradas outras de indivíduos cuja incapacidade era mais que patente; porque o juiz de paz e os dois do seu lado, com o seu - voto, voto, voto e desempate - tudo podia! E foi numa destas ocasiões que o tenente-coronel Faustino Francisco Branco, membro da mesa, se levantou e abandonou os trabalhos, indignado de tão imparcial procedimento.

As arbitrariedades do juiz de paz e de seus comparsas não pararam por aí: aparecendo 299 listas, se separaram as de um e as de outro partido, considerando-se válidas apenas aquelas que apoiassem os candidatos governistas. Terminada a apuração das listas do Serro, passou-se a apurar as listas do distrito de Nossa Senhora Mãe dos Homens: por estarem ali o escrivão e outras pessoas fidedignas de mérito para atestar a capacidade dos votantes do dito distrito, o juiz de paz começou a rasgar as cédulas com o objetivo de invalidá-las de uma vez por todas.

Foi então que em vista do modo arrogante com que o juiz de paz, desprezando todas as informações e proposições dos abaixo assinados, eles, indignados de ver em prática uma estratégia ignóbil e ilegal com que se procurava fazer eleitores que representavam, não a vontade livre do povo, mas os caprichos de um partido em diminuta minoria, tomaram a deliberação de se retirarem da mesa e protestar contra as eleições, porque além de não deverem presenciar um triunfo obtido em menoscabo da lei, se viam a cada momento sacrificados, pois constantemente rodeava a mesa um grupo de indivíduos, entre os quais alguns havia vestidos de ponchos, debaixo dos quais traziam armas e outros mesmo às escancaras, com consentimento do juiz de paz; notando-se que tinham vindo de fora do município, muitos destes assalariados, para estarem sempre prontos ao lado do juiz de paz e seus aliados políticos!! Servindo isto somente para incutir terror aos cidadãos pacíficos e inermes.

Afirmavam os peticionários que um procedimento tão degenerado nunca poderia ganhar o nome de expressão livre dos cidadãos brasileiros. Assim, os membros da mesa que não concordavam com os procedimentos da facção governista se retiraram. Para poder dar procedimento aos seus ignóbeis atos, o juiz de paz oficiou ao vigário da vara para que nomeasse um pároco substituto e, como obtivesse resposta que essa nomeação só poderia se dar caso o pároco viesse a falecer ou que ele mesmo nomeasse a outrem, 
chamou ao padre José Jacinto Nunes e arvorou-o em pároco, arrogando-se descaradamente de mais esta atribuição que não lhe competia. Nomeou também outro secretário e continuou a apuração dos votos, deu diplomas e reputou tudo legal e válido: em pouquíssimos dias, sem tempo hábil para que uma real apuração pudesse ser feita, o juiz de paz decretou que estava tudo terminado. Concluíam os indignados peticionários:

\begin{abstract}
quem não vê a manobra com que procedeu aquele juiz de paz, escolhido de propósito para fazer triunfar o seu partido, não estando no ano de seu governo e achando-se o proprietário de perfeita saúde, assim como o que the devia suceder em caso de impedimento? E como entendem os abaixo assinados que tais eleições estão sobremaneira carregadas de nulidades fazem esta exposição para que esta Augusta Câmara faça dela o uso que entender justo em sua sabedoria e os abaixo assinados confiam que os Representantes de uma Nação Livre não ouçam com indiferença tão graves atentados contra a Soberania do Povo. ${ }^{157}$
\end{abstract}

Os "atentados contra a Soberania do Povo" perpetrados pelos governistas na cidade do Serro se tornavam ainda mais graves quando um aliado do Gabinete Maiorista, deputado geral em exercício e reeleito naquela mesma ocasião, estivera envolvido na fraude. As acusações contra o facciosismo dos maioristas só faziam se confirmar posto que um de seus mais importantes aliados, o deputado Ottoni, havia participado ativamente do teatro de horrores em que havia se transformado as eleições em Minas Gerais. Ottoni juntava-se a D. Manoel, Alencar e Monteiro da Franca, acusado pelos regressistas de empreender medidas ilegais com o único objetivo de fazer eleger deputados dóceis ao partido do governo, em frontal desrespeito à livre expressão dos cidadãos brasileiros. Evidenciava-se o facciosismo dos maioristas quando surgiam provas do envolvimento de seus mais iminentes líderes em práticas que contrariavam as leis do Império.

Além das petições de autoridades locais de Minas, algumas petições com grande quantidade de assinaturas para os padrões do Segundo Reinado traziam acusações acerca dos abusos dos maioristas naquela província. Contendo 297 assinaturas, a queixa dos moradores da freguesia do Carmo demonstrava indignação contra irregularidades ocorridas durante as eleições para deputado geral em sua província.

Considerando-se sem representação à seguinte legislatura pelas nulidade e violência que presidiram às eleições; vêm perante esta Augusta Câmara denunciar as prevaricações e fatos criminosos que a uma minoria inquieta e turbulenta foi mister para conquistar o voto

157 Petição dos membros da mesa paroquial da cidade do Serro. 16 de janeiro de 1841. Centro de Documentação e Informação. Arquivo da Câmara dos Deputados. Brasília. Consultado em fevereiro de 2009. 
nacional e, se bem que esses fatos todos constam e são patentes da Ata [da eleição] que acompanha esta petição; todavia os abaixo assinados julgam melhor expor de um modo claro e sucinto os acontecimentos que tiveram lugar nos memoráveis dias um, dois e três de novembro de 1840, dias talvez que parecerão marcar o reinado da violência e do extermínio, dias, enfim, depois dos quais os abaixo assinados se julgam sem segurança, com sua propriedade em risco e prestes a serem despojados de tudo que tem de mais precioso sobre a terra.

Os homens abastados e industriosos do Carmo, relatava a petição, haviam sido vítimas da ação das classes proletárias que apoiavam os desmandos do juiz de paz Antonio Luiz Pinto, adepto dos maioristas. Impondo "o reinado da violência e do extermínio", ele desrespeitara a escolha do povo para um cargo da mesa a partir do descabido argumento de serem os cidadãos presentes no ato da aclamação incompetentes para tal escolha por não estarem qualificados. A evidente contradição do que dizia o juiz de paz estava no fato de que a qualificação somente se daria após a mesa ter sido aclamada. Apesar de impugnada pela maioria do povo, a minoria que apoiava o governo iniciou uma série de manobras para impor uma mesa paroquial que obedecesse às suas vontades. Seis homens nela se sentaram - três membros da maioria e três da minoria - e, ilegalmente, toda vez que havia algum empate quanto anulações, o juiz de paz reivindicava um suposto voto duplo, ou voto de qualidade.

Foi então que os abaixo assinados viram a traição e que todos os seus esforços para sustentar a monarquia eram contrariados por um pugilo de homens a tudo dispostos, que, como uma guarda pretoriana e embalada para invadir a igreja, só aguardava as ordens do juiz de paz para fazer fogo sobre aquele Povo inerme.

Ao passo que se iam recebendo as listas, o reverendo Ignácio Joaquim Nogueira as abria, e quando a votação lhe era desfavorável, mostravaas aos juízes da mesa e o juiz de paz, com o voto de qualidade, rejeitava; este escandaloso ato durou o tempo de qualificarem 103 listas, no qual rejeitaram o dobro, por terem à sua disposição quatro votos contra três.

Os abusos não tiveram fim naquele dia e, conseqüentemente,

no dia seguinte, todos os cidadãos se queriam retirar pois não tinham liberdade e muito menos segurança, porque a guarda do escolhido juiz de paz ameaçava a todos aqueles que não transigissem com a minoria e invadiram as portas do templo para coagir os Cidadãos e foi neste somenos que o capitão José Ribeiro da Luz requereu ao juiz de paz que dispersasse aquela guarda e que bastavam 4 ou 6 guardas nacionais para conter Cidadãos pacíficos e desarmados; mas o juiz de paz, que só almejava o triunfo custe o que custar, desprezou estas considerações e continuou no exercício do poder discricionário, isto motivou que muita gente abandonasse as eleições por não poder e não querer nada com a força e com o arbítrio; e chegou o escândalo a tal ponto que (...) [os fraudadores], juntando-se em um conventículo, pediram ao juiz de paz que forrasse a casa de estanho pois que era 
mister fazer entrar 50 ou 60 listas de nomes supostos para assim sobejar a oposição, e o juiz de paz, que não anelava outra coisa, de pronto subscreveu.

Contra aqueles que não mediam "esforços para sustentar a monarquia", a facção governista utilizara-se de tropas para concretizar a vergonhosa fraude na freguesia do Carmo. Desgostosos, os 297 signatários, depois de exporem todos esses abusos por parte do juiz de paz e de seus comparsas, requeriam dos representantes da nação enérgicas providências "para que de uma vez se firme o governo representativo e nunca seja falseado; e só destarte poderão os abaixo assinados ser legalmente representados." ${ }^{158} \mathrm{O}$ arbítrio, a violência e o escândalo dos fatos ocorridos na freguesia do Carmo não deveriam, de forma alguma, ser tolerados pelos escolhidos do povo brasileiro. O regime como um todo, e não só a segurança e a vida dos mineiros, estava ameaçado pela atuação ilegal dos maioristas no pleito do fim do ano de 1840 .

No dia $1^{\circ}$ de maio de 1841,315 cidadãos votantes da paróquia de Santa Rita do município mineiro do Presídio redigiram sua queixa aos representantes da nação:

não desejando guardar um criminoso e menos deixar passar incólume $\mathrm{o}$ ato mais atentatório de sua liberdade e direito constitucionais, vêm pedir remédio legislativo contra as violências dum partido, que conquanto se achasse em minoria, todavia apoiado pela prepotência dum governo excepcional qual o de então, só procurou suplantar a verdadeira expressão da nação, embora pelos mais ignóbeis, nefandos e revolucionários meios.

Mais uma vez, os maioristas eram acusados de patrocinar a barbárie durante o sagrado ato eleitoral em Minas Gerais e, ainda, eram retratados como um governo de exceção, pois que elevados ao poder depois de um golpe. Segundo os peticionários, no dia marcado para a eleição de eleitores para a futura legislatura geral, violências e imoralidades jamais vistas tiveram lugar em Santa Rita. Quando chegaram à igreja, os votantes constataram que o juiz de paz havia se submetido às vontades de uma camarilha turbulenta que servia, naquela vila, de arrimo para as extravagâncias da minoria governista. Formou-se, então, mesa eleitoral digna da demagogia daquele grupo que, quando evidenciou que estava de fato em minoria, usou de gritos e ameaças para garantir os caprichos da audaciosa gente.

Seguiram-se as maiores violências contra o juiz de paz de São José do Barroso, a quem, injusta e atrozmente, condenaram no perdimento do voto ativo e passivo. Vendo, porém, que a maioria sensata da paróquia se pronunciava contra a gente que só simpatiza com a política da

\footnotetext{
158 Petição dos moradores na freguesia do Carmo. 1841. Centro de Documentação e Informação.
} Arquivo da Câmara dos Deputados. Brasília. Consultado em fevereiro de 2009. 
agitação e da desordem, tomaram a bárbara e iníqua resolução de nulificar a maioria, rasgando e consumindo tantas cédulas quantas fossem necessárias para assegurar-lhes o triunfo.

Ao todo 266 votos foram tirados dos candidatos apoiados pela maioria da população, os quais, somados aos 157 que obtiveram apesar de tudo, daria um resultado inteiramente contrário ao que apareceu, pela fraude e ignomínia, favoravelmente aos aliados do ministério. Constataram os peticionários que a mesa recebia cédulas de homens sem idade e renda exigidas pela lei ou sem domicílio na paróquia. Havia ainda um desprezível assessor da facção governista que, enviado do centro do município do Presídio com as mais nefastas intenções, impedia que a mesa guardasse qualquer aparência de legalidade quando a fraude era por demais evidente.

Após o relato dos descaminhos do processo eleitoral em sua paróquia, os cidadãos votantes de Santa Rita lançavam um misto de súplica e ameaça aos deputados gerais:

os sofrimentos dos Povos constituídos em maioria, Augustos e Digníssimos Senhores Representantes da Nação, têm limites além dos quais não é lícito e nem possível zombar-se impunemente e, se a maioria dos co-paroquianos de Santa Rita revestiram-se de prudência em presença de tantos desatinos; da direta intervenção do Governo por seus ex-agentes; e da manifesta infração da Constituição e Leis; fundaram-se unicamente em que, por Vós, Augustos e Digníssimos Senhores Representantes da Nação, seriam declarados nulos esses atos que impropriamente se hão chamado eleições.

Os abaixo assinados esperam ser atendidos vendo cortar-se o progresso à imoralidade e, conseqüentemente, evitar-se cenas de horror que no futuro possam se dar. ${ }^{159}$

Os cidadãos daquela paróquia mineira sintetizavam tudo aquilo que se buscara dizer durante toda a discussão do ano de 1841 acerca das "eleições do cacete". A flagrante corrupção do processo eleitoral realizada pela "direta intervenção do Governo" poderia, segundo deputados e peticionários, caminhar para cenas de sangue e desgraça, comprometendo a existência civilizada da monarquia brasileira. A disputa entre partidos regulares, por causa da truculência daqueles que tinham a sustentação do Gabinete Maiorista, se transformara numa guerra entre facções. Cabia, então, aos próprios representantes do povo brasileiro cuidar para que seus postos mantivessem a legitimidade, podendo assim, em 1842, continuar a representar toda a nação e não somente a parte dela que impusera violentamente sua vontade.

\footnotetext{
${ }^{159}$ Petição dos cidadãos votantes da paróquia de Santa Rita do Presídio. 01 de maio de 1841. Centro de Documentação e Informação. Arquivo da Câmara dos Deputados. Brasília. Consultado em fevereiro de 2009.
} 
O relato dos cidadãos votantes de Santa Rita era confirmado por uma petição do juiz de paz de São José do Barroso e votante de Santa Rita, Manoel José da Silva. "O cidadão abaixo assinado," - iniciava ele - "foragido das mais bem fundadas esperanças, vem reclamar não só justiça aos seus direitos, mas também que seja a Lei desafrontada." Ocorrera que, no dia da eleição para eleitores em Minas Gerais - "dia que, na história das eleições, recordará sempre a época de sangue, de luto, de vergonha e de despotismo" - o peticionário se dirigiu, na qualidade de votante, com muitos outros cidadãos à igreja matriz de sua freguesia; lá, sem cumprir as formalidades exigidas pela ocasião, o juiz de paz local, "que de antemão se havia prostituído e rebaixado sua autoridade, indo do Presídio oferecer seus serviços na eleição a uma camarilha eminentemente infensa aos verdadeiros amigos da Monarquia Constitucional," dirigia os trabalhos. Não bastasse a prepotência com que agia o referido juiz de paz,

vendo-se os homens de 'vencer a todo o custo' em perfeita minoria, romperam em todo o gênero de violência, fraude e ameaças: a ordem desapareceu e esta minoria, tão turbulenta e revolucionária como a de quem é filha, capitaneada por um desprezível ente, que de propósito foi enviado da paróquia do Presídio, organizou a mesa dos desatinos, parte dos quais o abaixo assinado passa a referir.

O peticionário foi acusado pelos governistas de ter utilizado seu cargo de juiz de paz em São José do Barroso para subornar os seus concidadãos para propósitos eleitoreiros. Sem que ele ou qualquer testemunha fossem inquiridos, foi Manoel José da Silva condenado pela "mesa dos desatinos" a perder seu direito voto.

Desfraldada e assim aterrada a maioria e seus mais corajosos propugnadores, passou a mesa, qual fera indômita, a tragar quantas cédulas não continham os dez nomes de sua seita!! Cédulas foram rasgadas e lançadas embaixo da mesa a despeito da idoneidade dos votantes, a despeito do reconhecimento do competente escrivão de paz, a despeito dos clamorosos protestos, finalmente, da mais que mansa e pacífica maioria!

Completando a violência contra o direito constitucional dos votantes de Santa Rita, a urna foi levada à casa do juiz de paz local "e o sombrio véu da noite (segundo é voz pública na paróquia) ministrou-lhes o único recurso, o ignóbil, mas vasto campo em que deviam derrotar seus adversários políticos pela substituição das cédulas."

Diante da inaceitável corrupção do processo eleitoral ocorrido em Santa Rita, o peticionário levava seu apelo aos representantes da nação:

à vista da manifesta infração das Leis, e das arbitrariedades referidas, o abaixo assinado espera que serão declaradas írritas e nulas não só a decisão da mesa, mas também das eleições, que unicamente são a expressão de um pequeno e turbulento partido que, protegido a peito 
descoberto pelo governo de então, ao passo que oferecia empregos e postos na Guarda Nacional, prometia marcas de sofrimento aos que se não curvavam diante dos Mafomas. ${ }^{160}$

Em vossas mãos está, Augustos e Digníssimos Senhores Representantes da Nação, o poder que a Constituição vos deu de aplicardes justiça, cortando as esperanças dos partidos que pretendem vencer pela violência e fraude; o quê, a não verificar-se, ou as eleições d'ora em diante serão feitas com as armas na mão, e os futuros Representantes apresentar-se-ão com seus diplomas salpicados de sangue; ou eles representarão não a opinião das maiorias, não a dos cidadãos industriosos, úteis e abastados, mas sim a opinião dos proletários, a de uma minoria sustentada pelo furor dos sicários, enfim, a de homens que no país só tem direito ao ar que respiram. ${ }^{161}$

Caso resultados como aquele obtido na paróquia de Santa Rita fossem aceitos pelos representantes da nação, toda a ordem constitucional corria o risco de se esfacelar. O regime representativo, que se buscava estabelecer nas terras brasileiras, se transformaria num campo de guerra entre facções inimigas; os interesses mais relevantes da sociedade seriam esquecidos caso a vileza dos fraudadores tomasse conta do país. Manoel José da Silva temia que os "diplomas salpicados de sangue" obtidos pelos maioristas impedissem que os cidadãos de bem pudessem ver na Câmara dos Deputados legítimos representantes da nação.

Na Câmara, os relatos dos abusos eleitorais contidos nas petições eram incorporados ao discurso dos deputados tanto naquilo que tinham de factual quanto naquilo que tinham de defesa do regime representativo. Foi o caso, por exemplo, de Antunes Corrêa que repetia, em certa medida, a mesma conclusão tirada pelos votantes de Santa Rita:

eu posso asseverar à Câmara, sem ser profeta, que as coisas assim não vão bem e que, se continuarem, as instituições estão em perigo, o trono constitucional está a ponto de baquear, porque a sua primeira base é o religioso e exato cumprimento das leis que nos regem. ${ }^{162}$

As evidências da influência ilegal do governo maiorista sobre as eleições de 1840 se avolumavam, os pleitos em províncias como Sergipe, Pernambuco, São Paulo e até Rio de Janeiro estavam sob suspeita. No entanto, diante de tantas e tamanhas acusações, o ex-ministro dos negócios do Império, Antônio Carlos, repetia uma mesma justificativa:

\footnotetext{
${ }^{160}$ Mafoma é uma das grafias portuguesas de Maomé. Nesse caso, o termo foi usado em tom pejorativo, como sinônimo de infiel.

${ }^{161}$ Petição de Manoel José da Silva. 30 de abril de 1841. Centro de Documentação e Informação. Arquivo da Câmara dos Deputados. Brasília. Consultado em fevereiro de 2009.

${ }^{162}$ Anais da Câmara dos Deputados. 02 de junho de 1841. p. 345.
} 
o governo tem o mesmo direito que têm os outros cidadãos para influir nas eleições. Eu digo e disse sempre: no governo representativo há por necessidade duas opiniões: primeiro a que quer alargar, ensanchar as raias do poder e outra que as quer estreitar e alargar as raias das garantias populares. Estas duas opiniões lutam; o governo deve querer conservar-se, e como o há de fazer? Influindo nas eleições. Seria mister que o governo fosse uma cáfila de estúpidos se dissesse aos outros! - Vós podeis cabalar o quanto quiserdes, eu não posso cabalar como os outros. Vós podeis apresentar as listas de vossos candidatos e o ministério não pode fazer outro tanto. - Não: não pode ser vedado ao ministério o dizer às pessoas que o apóiam: - eu desejara tais e tais candidatos; vós que professais as doutrinas que estão no poder fazei com que sejam escolhidos, mas fazei como? Persuadindo aos vossos concidadãos, tanto quanto a lei não vos veda, não usando de fraude e violência: isso nem um nem outro partido deve fazer. ${ }^{163}$

Em resposta a esta justificativa, o deputado pernambucano Urbano Sabino Pessoa de Mello colocava que a teoria defendida por Antônio Carlos era perfeita para os países em que o regime representativo já se estabelecera definitivamente; no caso brasileiro, porém, onde a ordem constitucional ainda estava por ganhar vida plena na prática cotidiana, as idéias do ex-ministro apareciam como um incentivo a abusos.

Nos países civilizados tudo se obtém pelos meios legais, tudo está em harmonia: mas acontecerá o mesmo entre nós? Será aplicável a doutrina da Europa à província do Ceará? Será possível que, tendo a administração procurado intervir na eleição da província, depois de feita, fiquem os ânimos na mesma tranqüilidade, na mesma aquiescência com que se fica nos países civilizados? Não estamos vendo as circunstâncias tristes e funestas que aqui se têm seguido? Portanto, Senhores, contesto a doutrina do nobre deputado e entendo que o governo não deve influir nas eleições. (Apoiados.) ${ }^{164}$

De acordo com Sabino, para que o regime representativo pudesse se firmar no Brasil, o Poder Executivo deveria se manter distante das disputas eleitorais. A influência do governo sobre a decisão dos cidadãos era legítima em lugares onde a civilização já caminhava mais adiantada. No vasto e descontrolado território do Império, porém, a teoria de Antônio Carlos levava as facções a entrarem em guerra umas contra as outras.

A teoria do pernambucano, apesar do forte apelo que tinha para muitas figuras políticas do Império que desconfiavam da civilidade da população brasileira, não prevaleceu. A resposta mais efetiva ao ex-ministro maiorista veio do líder regressista Carneiro Leão que, adotando o mesmo princípio de Antônio Carlos, apelava para os fatos concretos:

\footnotetext{
163 Anais da Câmara dos Deputados. 19 de maio de 1841. p. 181.

${ }^{164}$ Anais da Câmara dos Deputados. 24 de maio de 1841. pp. 245-246.
} 
não se censura que os ministros concebessem uma opinião, tivessem um sistema e procurassem os aliados deste sistema e opinião: a censura que faço é que lançassem mão de medidas violentas, de homens virulentos, para conquistarem a maioria, quer na representação nacional, quer nas outras autoridades eletivas do Império, e houvessem de empregar a força e a violência, e mesmo a fraude e a calúnia, contra muitas outras pessoas amigas da ordem e da monarquia. É este o verdadeiro ponto das censuras que se fazem ao ministério passado; não é preciso, pois, que o nobre ex-ministro nos venha argüir de ignorarmos as condições do sistema representativo e de ignorarmos a utilidade que dos partidos se pode e deve tirar no mesmo sistema. Cumpria ao nobre ex-ministro mostrar que não seguiu a política que estou aqui apresentando. Pois escolher aliados que fossem capazes de executar os planos que houvesse concebido; mas que não usassem destes meios; que procurassem reunir todos os cidadãos ao trono do imperador, e não afugentá-los, apontando-os ao país e ao mesmo monarca como seus inimigos e da monarquia. ${ }^{165}$

Assim como a maioria da Câmara dos Deputados em 1841, Carneiro Leão esposava a mesma teoria de Antônio Carlos quanto à atuação do partido governista durante a disputa eleitoral; contudo, afirmava o líder regressista, o debate naquele momento não tratava de princípios teóricos, mas de acontecimentos concretos: as petições e os demais relatos apresentados demonstravam que os aliados do Gabinete Maiorista - fossem eles juízes de direito, juízes de paz, presidentes de província, ou quaisquer outros - haviam empregado "a força e a violência, e mesmo a fraude e a calúnia” durante o processo eleitoral que ocorrera em 1840. Carneiro Leão, diferente de Sabino, acreditava que no Brasil o ministério podia ter seus aliados e obrar com eles para que as eleições lhe dessem a maioria da Câmara; o que era inaceitável, todavia, era que para isso utilizasse de truculência e, assim, transformasse a disputa entre opiniões políticas numa guerra entre facções.

Deve-se atentar para um detalhe neste momento do texto: o que se considerava em meados do século XIX como coerção do direito de voto era muito diferente do que hoje se pensa sobre o assunto. O que se condenava então era a coerção física (violência) e a ruptura das regras previamente estabelecidas (fraude); o Poder Executivo podia utilizar largamente de sua influência para obter a maioria do parlamento contanto que restringisse seu campo de ação aos meios de convencer (este verbo é essencial para a compreensão da cultura política oitocentista) os votantes e os eleitores a apoiarem seus candidatos. Ou seja, se o simples fato, por exemplo, de um presidente regressista ser substituído por um presidente maiorista numa determinada província levasse o partido

\footnotetext{
165 Anais da Câmara dos Deputados. 25 de maio de 1841. p. 264.
} 
no poder a estabelecer alianças com as elites locais e estas alianças convencessem a maioria dos votantes e eleitores de que o melhor para eles seria eleger um representante maiorista, tudo estava dentro da ordem. O que se condenava, no entanto, era que o presidente apontado ordenasse que a polícia espancasse todos aqueles que não quisessem apoiar o seu partido nas eleições ou que enviasse pessoas estranhas para presidir mesas paroquiais com a finalidade de falsificar a expressão dos cidadãos.

O historiador Eduardo Posada-Carbó, ao analisar o fenômeno das fraudes eleitorais na América Latina oitocentista, afirma que é necessário, na análise histórica, se diferenciar corrupção eleitoral - suborno, falsificação de votos, violência física etc. de práticas baseadas em relações patrimonialistas, clientelísticas ou de deferência à autoridade. Enquanto estas práticas eram aceitas em diversos lugares no século XIX (inclusive na Europa ocidental e nos Estados Unidos), os abusos da lei eram condenados e combatidos. O tipo de influência dos governos sobre as eleições - explica PosadaCarbó - podiam variar muito, entre corrupção pura e simples e influência legítima. No caso limite das ditaduras de Porfírio Dias no México e de Juan Manuel de Rosas na Argentina, as eleições eram fabricadas pelo centro de poder por meio da violência, do controle da opinião pública e de outros expedientes que deturpavam o espírito das constituições liberais. Já no caso do Chile oitocentista, o presidente influía largamente sobre o processo eleitoral a partir de nomeações e distribuição de cargos, porém não possuía os meios, de que dispunham Dias e Rosas, de simplesmente impor suas vontades aos eleitores. Além das importantes nuances que existiam entre diferentes tipos de controle do governo sobre os pleitos, deve-se levar em consideração o fato de que, ainda que fraude e violência tenham sido práticas corriqueiras durante as eleições oitocentistas, os meios de corrupção eleitoral (que Posada-Carbó denomina "electoral tricks") estavam disponíveis tanto aos governistas quanto à oposição. ${ }^{166}$

Posada-Carbó considera que as fraudes e as violências tinham grande influência sobre os pleitos latino-americanos do século XIX e, por isso, não podem ser ignoradas pelos historiadores que se dedicam ao tema das eleições. No entanto, ele se opõe a uma visão historiográfica que enxerga o eleitorado absolutamente submisso ao controle dos governantes nacionais ou dos caudilhos locais. "For the newly organized independent states, the sudden emergence of an electorate of substantial size posed serious challenges. (...) The control of this electorate was not a simple operation. Neither was it

${ }^{166}$ Eduardo Posada-Carbó. Op. Cit. pp. 629-637. 
a settled process that remained unchanged throughout the century. What was evident in some cases was the lack of control over the electorate, and whatever control there was, this was not always unconditional. Moreover, it does not seem that governmental control was the generalized and defining feature of Latin American elections. These were often better defined by their level of conflict than by the attempts at controlling them."167 Compressão eleitoral era parte da realidade política latino-americana do século XIX; não há dúvidas quanto a este fato. Porém, isto não significa que a prática eleitoral do período possa ser explicada como a imposição de uma vontade superior sobre uma massa de cidadãos inertes. A existência de denúncias, tão recorrentes na América Latina oitocentista, acerca de abusos cometidos durante eleições (por meio de jornais, panfletos ou petições) demonstra que não havia aceitação pacífica do controle dos mais poderosos sobre o eleitorado; mas sim que, baseados nos ideais do liberalismo político em voga, setores da sociedade lutavam para garantir espaços de negociação em torno de seus direitos políticos. Em meio ao conflito se definiam as formas legítimas de se disputar eleições.

Antes de tirar suas conclusões acerca dos hábitos eleitorais do século XIX, o pesquisador deve atentar para o fato de que as populações das jovens nações viviam um processo de aprendizado político. O que propõe Posada-Carbó é que o historiador busque compreender como a competição eleitoral foi influenciada pelas práticas corruptas, como as elites e o povo compreenderam estas práticas e, finalmente, como elas foram combatidas, tendo sido formulados novos conceitos e novas instituições para se dar legitimidade à disputa por votos. Nas suas palavras: "there is something anachronistic, and even naïve, about those who persist in looking at the elections in the past merely as faithful or unfaithful expressions of the popular will. In their origins and development, elections could not have escaped from their natural and social ills."168 As eleições, como as demais instituições políticas, emanaram das práticas sociais vigentes. Compreender sua lógica pressupõe um esforço de compreensão das tensões que permeavam as sociedades dentro das quais as disputas se desenrolavam.

Muito provavelmente, no Império brasileiro não havia possibilidade de se fabricar eleições por meio da aberta compressão dos direitos constitucionais dos cidadãos, como ocorria nas ditaduras de Rosas e Dias. Os documentos analisados no presente capítulo mostram que a corrupção de fato ocorria no Brasil e que, pelo menos

\footnotetext{
${ }^{167}$ Idem. Ibidem. p. 641.

${ }^{168}$ Idem. Ibidem. p. 644.
} 
no ano de 1840, houve participação direta de delegados do poder central sobre os atos ilegais; contudo, mostram também que a fraude e a violência eram combatidas por um regime político que dava espaço à manifestação dos cidadãos (votantes, eleitores e autoridades que peticionavam à Câmara) e cujos estadistas - fossem eles de um ou outro partido - estavam atentos à questão da legitimidade da posição ocupada pelos representantes da nação.

No que se refere à influência do Poder Executivo sobre as eleições, é plausível a hipótese de que, com o objetivo de conquistar votos, as elites políticas do Império tivessem de negociar com votantes e eleitores e que, nesta negociação, a máquina pública fosse largamente utilizada. Tal hipótese vai ao encontro do que coloca Maria Odila L. S. Dias acerca das eleições no Brasil oitocentista: "havia por parte do governo central a vontade de influir sobre os ânimos locais, de pacificar as facções em luta e de conseguir um modus vivendi mais fácil. Criticava-se, no âmbito provincial, os excessos de prepotência dos potentados locais e, sempre que possível, procurava-se estender as malhas do poder central. O patronato, sem dúvida, exerceu influência sobre a arregimentação da população mais pobre, distribuindo empregos públicos e desta forma criando laços de clientela pessoal." ${ }^{\text {169 }}$ A historiadora explica que a intervenção do governo sobre votantes e eleitores, idealmente, tinha por objetivo mitigar os conflitos facciosos durante períodos de eleição: boa parte da elite política do Império acreditava que, ao cooptarem setores da população por meio da máquina pública, os governantes obravam por tranqüilizar os pleitos e, conseqüentemente, garantiam a legitimidade do processo eleitoral. As tentativas de cooptação não se confundiam, entretanto, com corrupção eleitoral. Acreditava-se, então, que expedientes como nomeações e distribuição de cargos governamentais faziam parte de uma negociação legítima para com os cidadãos brasileiros, a quem era dada a última palavra - aceitar ou não as benesses oferecidas pelos detentores do poder.

As análises de Posada-Carbó e de Dias se distanciam claramente da visão dominante na historiografia acerca das eleições no Império. Tal visão é desenvolvida de forma mais completa pelo historiador Richard Graham: segundo ele, no Brasil dos oitocentos os pleitos eleitorais serviam apenas para guardar a aparência de legalidade e constitucionalismo, sendo que, "se honestas, as eleições eram tumultuadas, e se

\footnotetext{
${ }^{169}$ Maria Odila L. S. Dias. “Sociabilidades sem história: votantes pobres no Império, 1824-1881” In: Marcos Cezar de Freitas (org.). Historiografia Brasileira em Perspectiva. São Paulo: Contexto, 2005. p. 70 .
} 
tranqüilas, eram desonestas." ${ }^{170}$ Há neste tipo de leitura uma evidente confusão entre as concepções atuais de legitimidade (ou honestidade) e os ideais abraçados pelos homens que viveram em meados do século XIX. Graham confunde práticas clientelísticas com corrupção eleitoral: para o referido historiador, assim como para boa parte daqueles que analisaram as eleições no Império, toda e qualquer influência sobre as eleições era sinônimo de fraude. Como foi possível notar até aqui, ainda que alguns parlamentares condenassem a influência do Poder Executivo sobre as eleições no Brasil, lideranças políticas tão diferentes (e importantes) quanto Antônio Carlos e Carneiro Leão concordavam quanto ao que se constituía como participação legítima de um partido sobre as disputas eleitorais. Agindo dentro da legalidade, as partes em disputa poderiam negociar com possíveis aliados nas localidades para conseguir votos para os seus candidatos. A negociação - que incluía o oferecimento de cargos e favores aos cidadãos - era muito diferente, para os contemporâneos, de corrupção eleitoral: ela era permitida e, em muitos casos, desejada como uma forma de inibir que conflitos violentos se instaurassem entre as partes em disputa nas diversas localidades.

O que diferenciava maioristas e regressistas em 1841, no entanto, era que estes tinham os meios de comprovar que aqueles haviam exercido fraude e violência eleitoral quando estiveram no poder. Sendo assim, Carneiro Leão lavrava sua condenação contra Antônio Carlos e seus aliados no pleito de 1840:

o ministério passado mandou para as províncias onde queria vencer nas eleições presidentes ad hoc, presidentes de sua afeição particular, como para Minas, São Paulo etc. Presidentes que partilhavam a opinião política dos ex-ministros. Não temos censurado a escolha dos agentes do poder da opinião política do ministério passado, mas porque, na posição particular em que se achavam, quiseram, segundo o sistema de seu governo, vencer com violência, não fazendo com que a administração fosse aceita pelo país. Os tory e os whig na Inglaterra têm por vezes governado: umas vezes têm a maioria os tory e outras os whig: e será isto porque metade da Inglaterra é tory e outra metade whig? Não: a maioria da nação não está nos grupos dos partidos: aceita as administrações segundo os planos que apresentam. Se eles são em conformidade com os interesses do país, opinião pública e necessidades então existentes, as mesmas idéias da oposição são aceitas e ganham maioria na nação. Assim, suposto eu pense que o partido a que pertencem os membros do ministério passado, ou aquele a que pertenceram antigamente, não têm a maioria do país, todavia apresentando-se com a honra de terem sido escolhidos pelo monarca, se seguissem outro plano, se tratassem de melhorar o país, de estabelecer nele melhoramentos morais, intelectuais e materiais: se, enfim, tratassem de consultar os verdadeiros interesses do país, deixando as pequenas idéias egoístas que algum dia professaram,

${ }^{170}$ Richard Graham. Clientelismo e Política no Brasil do Século XIX. Rio de Janeiro: UFRJ, 1997. p. 111. 
poderiam ter obtido a maioria da nação: mas isto é o que nego que fizeram: pretenderam conquistar a maioria pela força, pela fraude e pela violência e por isso é que eu os condeno. ${ }^{171}$

Em outro trecho do mesmo discurso, Carneiro Leão afirmava "que a obrigação do governo é vedar todas as fraudes, todas as falsificações (apoiados), manter a observância das leis; não venho proclamar a doutrina de que o governo não deve ter candidatos; não nego ao governo intervenção." ${ }^{172}$ O deputado regressista condenava o modo pelo qual atuaram os presidentes e os demais delegados dos maioristas, não o fato deles pertencerem ao partido do governo. Baseado no exemplo britânico, Carneiro Leão partia do pressuposto de que, num regime representativo, "os verdadeiros interesses do país" deveriam referendar a política de um determinado ministério por meio das eleições. Caso "a maioria da nação" concordasse com a atuação dos detentores do Poder Executivo, com suas escolhas e com suas propostas, elegeria representantes que partilhassem da mesma opinião do gabinete; caso contrário, daria seu voto à oposição. Explicava o deputado mineiro dirigindo-se a Antônio Carlos:

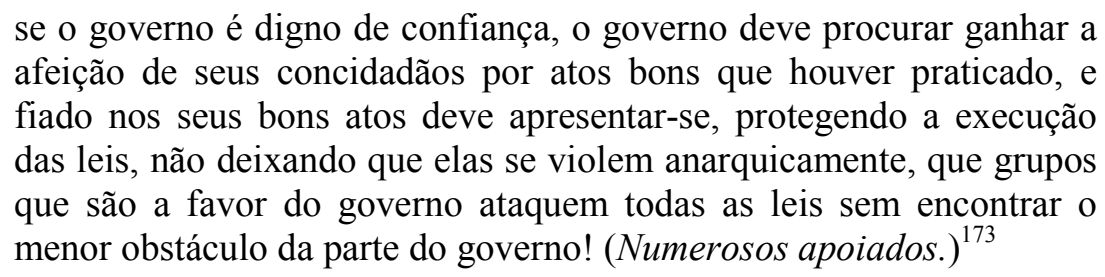

Sem poder convencer o eleitorado de sua competência, o Gabinete Maiorista quisera "vencer com violência", deturpando assim o sagrado direito dos cidadãos brasileiros. Concluía, então, o líder regressista que os homens eleitos no fatídico ano de 1840 não tinham legitimidade para representar a nação brasileira. É muito significativo o fato de que Carneiro Leão justificasse seu ataque aos maioristas por meio de argumentos muito próximos daqueles com que os peticionários escreveram suas queixas. Esta coincidência demonstra que as petições - meio de expressão política popular - se tornaram elemento fundamental para comprovar a ilegitimidade do pleito de 1840. Não bastava apenas a acusação proferida por Carneiro Leão ou por outros deputados do partido regressista para deslegitimar as "eleições do cacete". A opinião dos grupos de cidadãos que, em distantes rincões do Império, haviam sido vítimas da "teoria dos cacetes" sustentava a argumentação dos líderes parlamentares: eram os representados os primeiros a clamar por uma maior regularidade do processo eleitoral.

${ }^{171}$ Anais da Câmara dos Deputados. 25 de maio de 1841. p. 266.

${ }^{172}$ Ibidem. p. 258.

${ }^{173}$ Ibidem. p. 259. 
Baseados nas petições, os debates na Câmara estabeleciam o que era aceitável e o que era ilegal quando se tratava da disputa por votos e da influência que o Poder Executivo exercia sobre ela.

Quando, no dia $1^{\circ}$ de maio de 1842 , foi publicado nos Anais da Câmara o relatório que o ministério regressista de 23 de março dirigira a D. Pedro II poucos dias antes, ficava evidente que o debate sobre a corrupção eleitoral havia surtido grande efeito sobre os caminhos da política nacional:

\begin{abstract}
uma câmara legislativa eivada em sua origem por tantos vícios e crimes, desconceituada na opinião geral dos brasileiros que os testemunharam, jamais poderá conciliar a estima, veneração e prestígio que produzem a força moral, tão necessária a tais corpos políticos e à manutenção do regime representativo. Os seus atos não podem encontrar aquela obediência tão fácil e voluntária que é filha da convicção que têm os governados de que para eles concorreram por meio de uma eleição livre. Nem ela conseguirá, quaisquer que sejam seus esforços, dominar a razão social.

Entregue necessariamente à publicidade tudo quanto se passam em uma câmara legislativa, chama para o campo da discussão a inteligência, as paixões, os interesses de todos os membros da associação, é cotidianamente julgada, e condenada ou aprovada. De quanta força moral deve ela gozar, de quanta confiança deve ser revestida, para que não sofra quebra a sua autoridade por essas cotidianas sentenças?

Uma câmara legislativa desconceituada é a pior calamidade que pode afligir uma nação. ${ }^{174}$
\end{abstract}

O decreto imperial que dissolvia a Câmara eleita no final de 1840 acompanhava o relatório. O debate iniciado em 12 maio de 1841 com a apresentação de petições acerca dos abusos eleitorais patrocinados pelo Gabinete Maiorista, ainda que de modo indireto, influenciara a demanda do ministério e a conseqüente ação do Poder Moderador. A justificativa da primeira dissolução da Câmara dos Deputados no Império já estava presente no discurso produzido pela própria nação por meio da atividade peticionária. Antes mesmo de ser apropriada pelos deputados regressistas ou pelo ministério de 23 de março, a crença na ilegitimidade dos representantes eleitos em 1840 estivera no discurso dos peticionários. A Câmara eleita sob influência do Gabinete Maiorista sequer chegou a se reunir.

Entre 1842 e 1844, quando a Câmara foi ocupada por uma esmagadora maioria de aliados do partido do Regresso, pouquíssimas petições acerca de fraudes eleitorais foram enviadas pela população do Império. Talvez, o fato dos maioristas terem se

\footnotetext{
174 "Relatório a que se refere o decreto de $1^{\circ}$ de maio, dissolvendo a Câmara dos Deputados". Anais da Câmara dos Deputados. $1^{\circ}$ de maio de 1842. p. 90.
} 
ausentado do pleito após a dissolução explique a ausência das denúncias. Em 24 de maio de 1844, a Câmara foi novamente dissolvida pelo Poder Moderador e muitos dos antigos aliados dos maioristas - que agora começavam a se identificar como liberais, em oposição ao suposto conservadorismo dos regressistas - foram eleitos novamente. Logo, os acusados de fraude em 1841 procuraram uma solução para o problema que justificara sua queda.

Em 1842, por meio de um decreto, o gabinete de 23 de março regulamentara alguns aspectos do processo eleitoral no Império. Proibira-se o eleitor de "mandar por outrem a sua cédula" e estabelecera-se um método para a formação das mesas paroquiais que previa o sorteio de 16 cidadãos qualificados para serem eleitores e a designação, por estes 16 homens, dos membros da mesa. ${ }^{175}$ No entanto, o Regulamento de 1842 foi compreendido como uma medida muito restrita: os representantes da nação visavam regularizar, em todos os seus aspectos, o procedimento eleitoral no Brasil. Sendo assim, no dia 21 de janeiro de 1845, os deputados Manoel Odorico Mendes e Paulo Barbosa da Silva, ambos liberais mineiros, apresentaram aos seus pares um projeto de reforma eleitoral composto de 47 artigos e ofereceram-no à comissão de constituição e justiça para que fosse aperfeiçoado. Esta comissão era formada então por três nomes: Antônio Carlos, Sabino e Ottoni. Aqueles que em 1841 haviam se envolvido - inclusive como acusados - no debate acerca das "eleições do cacete", retornavam ao poder e se imbuíam da missão de acabar com a interferência de forças ilícitas nas eleições. A Câmara dos Deputados de maioria liberal tomava para si a missão de corrigir o mal que, havia poucos anos, justificara sua exclusão do Poder Legislativo por meio da dissolução prévia. Os ministros, numa atitude rara em debates tão graves como aquele, se mantiveram à distância: cabia aos próprios representantes sanar o vício que lhes deslegitimava perante a nação. Nas palavras de Barbosa da Silva:

\begin{abstract}
pensei que um dos serviços maiores que poderia prestar ao país era redigir um projeto de eleições no qual se desse a Deus o que é de Deus, a César o que é de César, e à nação o que é da nação.

$\mathrm{O}$ ato de eleger é o mais nobre para um povo livre; este deve fazer suas eleições sem interferência de nenhum poder e quem nelas quiser dominar comete um crime. (...) Trata-se da independência nacional, que não pode existir sem que haja independência e harmonia entre os poderes políticos. A invasão de um poder sobre o outro é sempre nocivo, rompe o equilíbrio, e roto ele, tudo é confusão e desordem. ${ }^{176}$
\end{abstract}

\footnotetext{
${ }^{175}$ Walter C. Porto. O Voto no Brasil. Da Colônia à $6^{a}$ República. Rio de Janeiro: Topbooks, 2002. pp. 66-67.

${ }^{176}$ Anais da Câmara dos Deputados. 14 de fevereiro de 1845. p. 639.
} 
Baseado no mesmo ideário das petições de 1841 - a "independência e harmonia entre os poderes políticos" - o projeto de reforma, revisado pela comissão, previa basicamente a adoção de sete medidas: $1^{a}$ ) a criação de uma junta responsável por qualificar os votantes composta por um presidente, o juiz de paz do distrito ("esteja ou não em exercício, tenha ou não tomado posse do cargo, esteja embora com escusa ou suspenso"), e mais quatro ou seis membros (dependendo do número de eleitores da paróquia) nomeados pelos eleitores da localidade. Do mesmo modo se procederia à formação da mesa paroquial que, além de receber as listas e zelar pela ordem no dia das eleições, deveria proceder à apuração dos votos sem, contudo, "conhecer da idoneidade dos votados". A mesa teria poder para decidir sobre quaisquer dúvidas que surgissem, sendo que elas se resolveriam pelo voto da maioria dos seus 5 ou 7 membros; $2^{\mathrm{a}}$ ) a regulamentação do recebimento e apuração das cédulas a partir: i.) da fixação de 3 chamadas dos qualificados no fim das quais não mais seria permitido receber as listas; ii.) da proibição de cédulas com nomes rabiscados, alterados ou substituídos; iii.) da lacração, da proteção e da exposição pública da urna durante todos os dias de eleição; iv.) da manutenção do segredo do voto; $3^{\mathrm{a}}$ ) a fixação de datas unificadas para eleições primárias e secundárias válidas para todo o Império; $4^{\mathrm{a}}$ ) a indexação à prata dos valores exigidos para participação de votantes e eleitores nos pleitos; $5^{\mathrm{a}}$ ) a suspensão do recrutamento militar em todo Império dois meses antes e um mês depois da data fixada para o processo eleitoral e a proibição dos "arrumamentos de tropas e qualquer outra demonstração de força militar no dia da eleição primária a uma distância menor de uma légua do lugar da eleição", a menos que assim requeresse o presidente da mesa paroquial com objetivo de manter a ordem; $6^{\text {a }}$ ) a fixação de um eleitor para cada 100 votantes e de um deputado geral para cada 80 eleitores da província; $7^{\mathrm{a}}$ ) a inelegibilidade ao cargo de deputado ou senador, nas províncias em que exercessem jurisdição, dos generais em chefe, dos comandantes de armas, dos chefes de polícia, dos administrados da fazenda provincial, dos presidentes de província e dos juízes de direito. $^{177}$

Como se pode notar, o projeto de reforma tinha um objetivo central: regulamentar - até seus detalhes - o modo de se proceder às eleições no Império, evitando que abusos impedissem a livre expressão da vontade dos cidadãos na escolha dos representantes da nação. Até então, o processo eleitoral no Brasil se dava de acordo

${ }^{177}$ Anais da Câmara dos Deputados. 06 de fevereiro de 1845. pp. 494-500. 
com as prescrições contidas na Constituição de 1824 - que fixavam apenas quem teria direito de votar e ser votado - e com as instruções de 26 de março de 1824 - as quais, basicamente, definiam que a mesa paroquial seria formada pelo juiz de fora (juiz de paz após 1827), pelo pároco local e por mais quatro membros aclamados pelo povo -; havia, além destes, o já citado decreto de 1842, que não satisfizera a maioria dos parlamentares. Entendiam os autores do projeto que os abusos freqüentes ocorridos por ocasião de eleições deviam-se à falta de precisão dos regulamentos existentes até então.

As medidas que propunham tinham relação direta com o discurso das petições que tanta repercussão causaram em 1841: com a regulamentação do modo de escolha dos membros da junta e da mesa paroquial, pelos eleitores da localidade, visava-se acabar com as sempre controversas aclamações; com a fixação de um número ímpar de membros da mesa paroquial (5 ou 7), visava-se colocar fim aos abusos perpetrados por autoridades que se arrogavam poderes inexistentes na letra da lei, como o voto duplo; com a regulamentação do recebimento e da apuração das cédulas, visava-se inibir os desmandos daqueles que rasgavam listas, impunham o recebimento de cédulas falsificadas, seqüestravam urnas ou coagiam votantes e eleitores; com a fixação de datas únicas para as eleições em todo o Império, visava-se impedir que certos grupos levassem a cabo as eleições na data que melhor lhes conviesse; com a indexação do censo à prata, visava-se inibir chefes facciosos de utilizar o populacho como massa de manobra durante eleições; com a suspensão do recrutamento militar e do ajuntamento de tropas em período eleitoral, visava-se colocar fim, a um só tempo, às chantagens sobre os votantes pobres (que, usualmente, tinham pavor de serem obrigados a servir ao Exército) e às violências cometidas por milícias interessadas no resultado da eleição; com a fixação de uma proporção exata entre votantes, eleitores e deputados gerais, visava-se impedir que certas províncias fossem super-representadas e que nelas o voto valesse mais do que em outras partes do país.

Note-se que não havia nada no projeto que versasse sobre a influência do Poder Executivo durante o período de eleições. Havia, entretanto, o artigo das inelegibilidades, o qual visava conciliar a distribuição de cargos públicos com a separação dos poderes no Império. Ao propor que generais em chefe, comandantes de armas, chefes de polícia, administrados da fazenda provincial, presidentes de província e juízes de direito fossem impedidos de se eleger deputados ou senadores na província em que exerciam suas funções, os propositores da reforma não visavam impedir que o ministério apoiasse seus aliados nas diferentes localidades do Império durante o processo eleitoral. Visavam, 
sim, evitar que os principais agentes do Executivo e do Judiciário dominassem o Legislativo e, desse modo, prejudicassem a separação das esferas de poder que vigorava nos regimes políticos constitucionais do século XIX. A natureza de tal medida causou grande polêmica na discussão parlamentar, pois alguns deputados acreditaram que ela seria prejudicial ao país na medida em que excluiria da representação nacional iminentes figuras políticas que faziam parte da administração pública; sendo assim ela sofreu - como se verá posteriormente - significativa alteração, sendo aplicada somente às eleições para as Assembléias Provinciais.

Depois de apresentada a proposta da comissão, a Câmara adentrou um aceso debate: muitos discordavam das benesses de algumas medidas e queriam modificá-las ou excluí-las, outros achavam o projeto insuficiente e apresentavam emendas; contudo, uma opinião prevalecia: a de que uma lei de eleições era mandatória naquele momento. O deputado pernambucano Jerônimo Vilela de Castro Tavares foi o primeiro a expressar claramente este sentimento em 1845 :

Senhores, quando todas as conveniências públicas e o interesse vital do Estado reclamam séria atenção a respeito da eleição dos representantes do país, visto que uma experiência sempre infeliz acompanhada de sucessos bem fatais nos tem provado pela maneira a mais clara e positiva que a maior parte dos males do Brasil têm provindo do modo prático por que se fazem as eleições entre nós (apoiados); quando as necessidades do país reclamam do corpo legislativo uma lei de eleições que venha arredar todos os abusos que se praticam, obviar todos os inconvenientes e males que sofremos, não serei eu que me levante para impugnar in totum um projeto que sem dúvida tem disposições muito boas; não serei eu quem me levante para impugnar um projeto que, no meu entender, vem moralisar o processo eleitoral, garantir a boa escolha dos representantes da nação e o socego e tranqüilidade pública em épocas de eleição.

O país todo conhece que é mister uma lei de eleições, que uma semelhante lei é uma das necessidades mais palpitantes e é preciso que os inimigos da liberdade se convençam que a eleição não é domínio, não é patrimônio de alguém, mas sim obra do povo e que, por conseqüência, cumpre não estabelecer estorvos no seu processo, não impôr à consciência dos cidadãos o voto que eles devem dar. ${ }^{178}$

A necessidade de uma reforma eleitoral que pusesse fim aos abusos era sentida mesmo pelos deputados que fizeram as mais duras críticas ao projeto. O consenso acerca da necessidade de se combater a fraude era tão forte que até mesmo o baiano Ângelo Muniz da Silva Ferraz, líder conservador na Câmara em 1845, admitia que a preocupação dos propositores da reforma era uma preocupação legítima.

${ }^{178}$ Anais da Câmara dos Deputados. 13 de fevereiro de 1845. p. 605. 
Eu entendo, Sr. presidente, que uma das necessidades mais palpitantes que temos é uma boa lei de eleições. Esta necessidade é sentida por todos; na consciência de cada um de nós acharemos uma prova do que acabo de dizer. (...) O nobre deputado autor do projeto, morador na província do Rio de Janeiro, conhecendo a palmos tudo o que nela se fez, todos os abusos, fraudes e torpezas que tiveram então lugar, por certo fez um relevante serviço ao país apresentando o projeto que está em discussão. Eu considero, Sr. presidente, que uma pessoa que, conhecendo os males que sofre o seu país, cura de remediá-los com medidas de natureza destas, é digna de todos os elogios. ${ }^{179}$

Declarações como esta não significavam que o projeto tinha apoio irrestrito de toda a Câmara, mas apenas que se reconhecia geralmente o seu mérito de ter colocado para a discussão aberta um tema vital para toda a representação nacional. A experiência recente com a "teoria dos cacetes" parecia, de fato, ter demonstrado a importância de uma ampla reforma eleitoral à maioria dos membros da Câmara dos Deputados. A única voz que declaradamente negava a importância de uma lei contra as fraudes eleitorais era a de D. Manoel de Assis Mascarenhas, ex-presidente do Rio Grande do Norte e eleito em 1844 deputado geral pela província de Goiás.

No estado em que se acha o país, uma lei de eleições será como semente sem força que cai em terra estéril e cansada. Dizei-me com boa fé: estais convencidos que com o projeto que se discute acabarão ou ao menos diminuirão tantas fraudes, tantos abusos, tantos crimes mesmo cometidos no momento solene em que a nação é chamada a exercer o mais precioso de seus direitos, o direito de eleição? Eu tenho infelizmente a convicção contrária e por isso nada espero do presente projeto.

(...) Senhores, enquanto nós nos não desenganarmos de que as leis não são feitas unicamente para serem executadas nas principais cidades do Império onde há ilustração, mas também no interior do mesmo Império, que está ainda assaz inculto, nós seremos forçados a revogar e alterar todos os anos as legislações do país. Vêde o que aconteceu com a Lei da Guarda Nacional, com o Código do Processo e com outros atos legislativos que a prática demonstrou evidentemente serem inadequados ao estado de civilização do Brasil. Quem, por exemplo, entenderá no interior do país a palavra - eqüidistante - de que tantas vezes fala o projeto em discussão?

(...) Quando algum indivíduo pouco ilustrado pedir a explicação da palavra - eqüidistante - responder-lhe-ia outro mais esperto e astucioso: - quer dizer... que se deve votar na chapa que vos apresento. (Risadas. $)^{180}$

A ironia era a característica marcante da maior parte dos discursos de D. Manoel: segundo Joaquim Manuel de Macedo (literato, cronista e biógrafo da elite política imperial), D. Manoel “tinha palavra fácil, memória assombrosa, prontidão no

\footnotetext{
${ }^{179}$ Anais da Câmara dos Deputados. 16 de fevereiro de 1845. p. 676.

${ }^{180}$ Anais da Câmara dos Deputados. 13 de fevereiro de 1845. pp. 613-615.
} 
improviso, entusiasmo pelos princípios que sustentava, e era terrível no sarcasmo, excedendo-se às vezes no ataque violento ao adversário." ${ }^{181} \mathrm{O}$ objetivo do representante goiano era desacreditar as intenções dos reformadores. Figura ímpar da política imperial, entre 1837 e 1841 (sob os ministérios regressista e maiorista) ele havia sido presidente da província do Rio Grande do Norte e - conforme relataram petições apresentadas na Câmara em 1841 por Elvídio Carneiro da Cunha - permitira os abusos do partido do sul para se beneficiar politicamente. Avesso a mudanças, D. Manoel negava a importância de reformas parlamentares enquanto boa parte população nacional se mantivesse estranha às regras constitucionais. Todavia, os fatos acerca dos abusos e a crença na missão civilizatória da representação nacional isolavam sua opinião. Ele se tornava voz solitária dentro da Câmara, único a acreditar que leis não teriam efetividade nas regiões mais isoladas do Império. Não foram poucos aqueles que se irritaram com o posicionamento de D. Manoel - eis como lhe respondeu o pernambucano Vilela de Castro:

181 Joaquim Manuel de Macedo. Anno Biographico Brazileiro. Segundo volume. Rio de Janeiro: Typographia e Litographia do Imperial Instituto Artistico, 1876. p. 524.

${ }^{182}$ Anais da Câmara dos Deputados. 14 de fevereiro de 1845. pp. 635-636. 
Vilela de Castro atacava D. Manoel por ter se utilizado, nas eleições de fins de 1840, da compressão para se fazer eleger deputado pelo Rio Grande do Norte. Ficava subentendida nesta acusação uma crítica à atuação dos maioristas durante as "eleições do cacete" já que o ministério, como foi dito anteriormente, era responsável por apontar os presidentes provinciais. No entanto, isto não impedia Vilela de Castro de reconhecer que uma lei que provesse os cidadãos de segurança para poderem efetuar a escolha livre de seus representantes era o desejo da maioria e que o partido no poder deveria obrar por ela.

Para os defensores da necessidade de reforma eleitoral, o povo brasileiro aspirava por uma ordem política compatível com as nações mais cultas do século XIX. Diferentemente do que pensava D. Manoel, a sociedade nacional era capaz de agir em conformidade com os rituais do mundo civilizado: bastava que seus legisladores the dessem os meios para isso. O representante da Bahia, João José de Oliveira Junqueira, mesmo sendo membro da oposição conservadora, comungava desta tese e respondia ao deputado goiano que era a falta de boas leis e não seu excesso que causava os infortúnios que enfrentava a nação brasileira.

Sr. presidente, um ilustre deputado por Goiás exclamou: - para que ides fazer leis em um país desmoralizado; as leis não farão mais do que complicar o nosso estado; elas não poderão aproveitar - e, por conseqüência, concluíu votando contra o projeto.

Senhores, também não é esta a maneira de argumentar. (...) O que seria dos romanos se não fosse Numa Pompílio? Eles eram um bando de salteadores; e o que fez deles uma nação de heróis? Seria o clima de Roma? Vêde os descendentes de Scipião e de Marco Aurélio... logo, não foi o clima, foram as instituições, as instituições são capazes de corrigir os costumes e de prevenir as fraudes... É verdade que, segundo um ditado inglês: - a piedade edifica a igreja, o demônio põe logo ao pé uma taberna. - Isto é, por outras palavras, segundo disse um nobre deputado quando orou: - pensate alla legge, pensate alla malicia. - Os homens procuram logo todos os meios de iludir a lei. Mas o nobre deputado poderia negar que apresentando-se certos meios, se torna mais dificultosa essa fraude? Seguramente; eu o mostrarei mesmo com o projeto. (...) Vejo que o projeto tem idéias boas, que sendo o projeto um daqueles, como muito bem se tem dito nesta casa, que a nação brasileira reclama com mais instância, que sendo um projeto que é necessário que seja organizado, por isso mesmo que a Constituição manda fazer uma lei regulamentar, nós todos, animados de boa fé, devemos tratar de emendá-lo, porque cada um de nós deve desejar a honra de sentar-se aqui quando for a expressão legítima do povo.

(...) A minha doutrina é toda a liberdade de voto, para que não haja pretexto nunca de dizer - eu rebelei-me porque não tive liberdade de voto, porque o governo influiu nas eleições por meio de seus subdelegados. 
Não pode haver mais pretexto para isso. (...) Se a nação tem urnas com todas as garantias, acaso terá de recorrer-se a outros meios senão a este? Por conseqüêcia quero acabar com todos os pretextos para saltar sobre as leis. Quem tem meios de vir como representante para esta casa, quem tem meios de vir sustentar aqui as suas doutrinas, não deve recorrer a meios arbitrários. (Apoiados.) É um grande serviço que se faz ao país em acabar com todos os pretextos. ${ }^{183}$

Junqueira invertia o argumento de D. Manoel ao dizer, referindo-se aos movimentos rebeldes que assolaram o Império durante as décadas de 1830 e 1840, que a desordem no país provinha da falta de regulamentação clara do processo eleitoral e não da ignorância dos cidadãos. Segundo este ponto de vista - compartilhado por todos os defensores da reforma e também pelos peticionários estudados neste capítulo - garantir a legítima representação da nação seria um modo de se estabelecer no Brasil uma ordem compatível com o mundo civilizado. No entanto, buscando enfraquecer o ministério liberal recém-empossado, Junqueira exigia que a reforma acabasse de uma vez por todas com qualquer influência do Executivo sobre as eleições. Assim também fazia o dissidente liberal Joaquim Nunes Machado:

eu creio que não haverá uma só pessoa que não sinta e reconheça a necessidade urgente de uma lei de eleições, as quais não devem continuar a ser reguladas pelas leis existentes que autorizam as fraudes, as cabalas, os crimes e põem à mercê do governo o exercício de um dos mais importantes direitos dos cidadãos, que é a essência de sua vida política.

Uma lei pois, Sr. presidente, que, removendo todos esses embaraços, e proibindo principalmente que o governo se intrometa em um negócio que nada tem com ele, garanta a liberdade do voto e habilite o cidadão para poder escolher como quiser os seus representantes, salta aos olhos de todos os homens que se dão ao estudo dos negócios públicos e conhecem o novo sistema que é de absoluta necessidade. ${ }^{184}$

Aliando-se aos conservadores, Nunes Machado, um liberal radical que em Pernambuco fundara o partido da praia, não admitia que o governo exercesse qualquer tipo de influência sobre a vontade dos cidadãos na escolha dos representantes da nação. Este posicionamento, entretanto, foi minoritário em 1845; prevalecia a opinião daqueles que acreditavam que o governo podia (e devia) influir sobre as disputas eleitorais com o objetivo de torná-las mais pacíficas. O deputado Antonio Manoel Campos de Mello, liberal paulista, atacava aqueles que, com propostas radicais, atrapalhavam a consolidação de eleições legítimas no Império:

\footnotetext{
183 Anais da Câmara dos Deputados. 19 de fevereiro de 1845. pp. 716-717.

${ }^{184}$ Anais da Câmara dos Deputados. 13 de fevereiro de 1845. p. 610.
} 
ora, pergunto eu, se queremos o governo representativo, podemos acaso continuar com uma legislação semelhante? Não deveremos empregar todos os esforços para remediar esse grande mal, para fazerse com que nesta parte a legislação de nosso país apresente um inconveniente menor, o menor que possa ser? Entretanto, os nobres deputados que reconhecem isto não só não querem obstinadamente fazer coisa alguma, como nem também consentem que os seus adversários procurem remediar essa necessidade pública, removendose a causa de tantos clamores, dando-se realidade ao governo representativo, e fazendo-se com que haja justiça no país. ${ }^{185}$

Estava em jogo naquele momento a respeitabilidade de algumas figuras políticas que, depois de terem sido gravemente acusadas entre 1840 e 1841 , visavam continuar a disputar cargos de poder no Império. Os liberais, com a importante exceção de Nunes Machado, permaneciam fiéis ao que Antônio Carlos defendera em 1841: seu partido devia buscar a vitória eleitoral apoiando seus aliados nas diversas províncias brasileiras; não podia, entretanto, compactuar com fraudes e violências durante os pleitos.

Vendo-se em posição minoritária, os críticos da proposta apelaram para as denúncias contra os maioristas com o objetivo de deslegitimar a reforma proposta pelos liberais em 1845. Eis como se colocou, por exemplo, o conservador mineiro Herculano Ferreira Penna ao se referir a acontecimentos de sua província:

desde que se foi exaltando o espírito de partido, desde que o governo entendeu que podia ter uma ingerência direta nas eleições, desde que o governo entendeu que podia usar até da força, desde que se estabeleceu a teoria da confiança, em virtude da qual começaram a ser demitidos funcionários públicos, honrados e hábeis, só porque não pensavam como o governo em matérias puramente políticas; desde que os partidos proclamaram que em tempo de eleições são lícitos todos os meios de vencer, nós temos visto a série de escândalos que se tem apresentado; nós temos visto o arrojo com que se figura a existência de colégios monstruosos, como o do Saboeiro e outros; nós temos visto os ferimentos, os assassinatos e os atentados de toda a espécie cometidos por ocasião de eleições; o escândalo da imoralidade chegou finalmente a ponto de passar como princípio corrente que, constituída a mesa, estava feita a eleição, porque ela se encarregava de exprimir o voto dos cidadãos, posto que eles não tivessem votado. (Apoiados.) É pois evidente, Sr. presidente, que de certa época por diante os fatos constantemente observados no Império fizeram levantar um clamor muito justificado contra o modo prático das eleições, reconhecendo os homens de todos os partidos que (...) muitas vezes deixavam de concorrer os cidadãos mais prudentes ou mais tímidos, porque a coação, os insultos e as ameaças os faziam recuar, deixando o campo livre aos que fossem mais corajosos e mais ousados para fazer triunfar a chapa do seu partido. ${ }^{186}$

\footnotetext{
185 Anais da Câmara dos Deputados. 09 de abril de 1845. p. 517.

${ }^{186}$ Anais da Câmara dos Deputados. 14 de fevereiro de 1845. p. 627-628.
} 
Era parte da estratégia da oposição trazer à lembrança dos deputados as "eleições do cacete". Por esta via buscavam retirar dos liberais, muitos deles envolvidos diretamente nos acontecimentos de fins de 1840, a legitimidade para conduzir a reforma eleitoral. Entretanto, agora os próprios acusados se aproveitavam das denúncias para justificar o seu projeto. Fortaleciam, assim, seus laços com o regime constitucional brasileiro e com o eleitorado nacional. Depois de tantas turbulências - eleições violentas, acusações de corrupção, dissolução da Câmara etc. - os acusados de outrora se erguiam ao posto de defensores da legitimidade do poder político no Império. Assim também Sabino, que em 1841 criticara Antônio Carlos e os demais maioristas, unia forças com o ex-ministro e defendia a reforma liberal.

O nosso pensamento político em eleições é este - a eleição pertence à nação, ela deve ser depositada nas mãos da nação; nós queremos vencer ou perder com a nação! Se o país entender que não merecemos a sua confiança, se quiser mudar de política, então elege pessoas de outro credo; mas o que se quer é que a nação tenha o direito de eleger; a oposição não quer isto, a oposição quer a eleição sempre depositada nas mãos do governo, ainda quando a oposição não está no poder. ${ }^{187}$

Invertendo a argumentação dos seus adversários, Sabino - membro da comissão parlamentar que aprimorara a proposta junto de Ottoni e Antônio Carlos - acusava os conservadores de quererem impedir a reforma para poderem continuar a dominar, por meios ilícitos, o voto dos cidadãos brasileiros. O líder pernambucano se distanciava de seu co-provinciano Nunes Machado e se unia aos demais liberais na consecução de uma lei que estabelecesse o que seria legítimo e o que seria ilegítimo quando da disputa por votos.

Manoel de Mello Franco, liberal da província de Minas Gerais e defensor da proposta, repetia em 1845 a teoria que tanto Antônio Carlos quanto Carneiro Leão haviam defendido em 1841: "não julgo," - dizia perante seus pares - "que o governo fique privado pela lei que se discute daquela influência protetora, permanente e única que lhe compete, e que sempre há de ser de grande importância." Entretanto, aos detentores do Executivo não deveria mais caber "o poder de fazer eleger a quem muito bem lhe aprouver" por meio de "escândalos que desgraçadamente se têm multiplicado por quase todas as partes por causa de eleições". Ao governo caberia simplesmente utilizar de sua influência para "refrear as facções" e não para agitá-las ainda mais. ${ }^{188}$ Venciam, naquele debate, os deputados que acreditavam na necessidade de uma lei que

${ }_{187}^{187}$ Anais da Câmara dos Deputados. 21 de fevereiro de 1845. pp. 759-760.
${ }^{188}$ Anais da Câmara dos Deputados. 07 de março de 1845. p. 89. 
regulamentasse a influência do governo sobre as eleições, fechando o caminho para os abusos e permitindo que a ordem fosse mantida. A reforma, diziam seus defensores, impediria que o país se transformasse num palco para a guerra entre facções sem, contudo, fazer com que os detentores do Executivo deixassem de exercer a influência que, dentro da legalidade, pudesse lhes dar a desejada maioria parlamentar.

O partido liberal, que ia naqueles anos ganhando contornos nacionais, visava inserir-se na ordem política do Império sanando os males que, outrora, haviam sido imputados a alguns de seus principais líderes. Assim, o próprio Antônio Carlos se transformou em 1845 no maior combatente pela legitimidade do processo eleitoral no Império. Dizia ele em um de seus discursos:

\begin{abstract}
um povo que quer ser povo livre, um povo que não quer abdicar a liberdade, a espontaneidade, porque isto é a essência do homem, precisamente deve curar ele mesmo dos seus interesses. Nos primeiros tempos, na infância da sociedade, o povo curava diretamente dos seus negócios; quando porém a sociedade aperfeiçoou-se, quando se complicou demais e mesmo a população cresceu em demasia, era impossível que a massa inteira do povo curasse de si e por isso escolheu procuradores; e então o que deviamos fazer? Era verificar a verdade da procuração, a legitimidade, a certeza da vontade popular; isto é o que me parece que tiveram em vista os nobres deputados que ofereceram o projeto, no qual igualmente trabalhou a comissão de que sou indigno membro (não apoiado). ${ }^{189}$
\end{abstract}

O deputado paulista adotava o discurso que fundamentava o regime representativo: defendia que a escolha livre dos representantes da nação era direito sagrado daqueles que não podiam governar por si mesmos. Antônio Carlos visava redimir o nascente partido liberal das acusações de facciosismo que sobre ele pesavam desde 1840: os maioristas, segundo a sua lógica, não haviam adotado por conta própria a "teoria dos cacetes"; a falta de regulamentação eleitoral, sim, fora a causa dos abusos do famigerado pleito. A lei que o seu partido propunha agora em 1845 acabaria de uma vez por todas com as fraudes e as violências, regularia a vida política no Brasil, não daria mais espaço para que a turbulência facciosa prejudicasse a liberdade de escolha dos cidadãos. O paraibano Nicolau Rodrigues dos Santos França Leite, um situacionista, fazia coro a este ideário:

temos ainda nesta missão especial uma circunstância que não deve ser desprezada e é fazer a lei de eleições pelo modo prático pelo qual possam elas ser, não a expressão da cabala, da intriga e da coação, mas a expressão pura do voto nacional. Isto posto, creio que a Assembléia Geral está revestida do poder de tirar todos os embaraços

${ }^{189}$ Anais da Câmara dos Deputados. 10 de março de 1845. pp. 116-117. 
que no exercício do poder eleitoral possa fazer com que o voto não seja expressão fiel dos votantes. Isto demonstra pois que a Assembléia Geral está revestida dos poderes necessários para fazer uma lei de eleições que dê em resultado a expressão fiel do voto dos cidadãos, a expressão fiel da consciência, da vontade do eleitor; e se está revestida deste poder está necessariamente revestida do poder de tirar todos os embaraços, de remover todas as dificuldades que tornam o exercício deste poder incompatível com a obrigação que a Constituição encarregou à Assembléia Geral. ${ }^{190}$

França Leite era um liberal da Paraíba, província que, em 1841, fora apontada como um dos locais de atuação dos fraudadores a serviço do Gabinete Maiorista. Segundo ele, estava nas mãos dos deputados eleitos em 1844 a tarefa de firmar no Brasil, de uma vez por todas, o regime representativo: a Câmara de maioria liberal estava preparada para regularizar as disputas por votos no Império. Também o padre José Antonio Marinho, um liberal de Minas Gerais, abraçava o ideal dos defensores da proposta: "desejando nós todos uma lei de eleições que o país reclama," - bradava “desejamos que ela seja quanto possível for uma expressão fiel da verdade e que possa conduzir também o país a apresentar uma expressão igualmente fiel da opinião pública." "191 Aqueles que haviam sido acusados de promotores da barbárie durante as "eleições do cacete" buscavam sua redenção ao defenderem os preceitos fundamentais do regime representativo.

A Lei Regulamentar das Eleições do Império ganhou vida definitiva no dia 19 de agosto de 1846 com muitas emendas e modificações em relação ao projeto apresentado pela comissão de contituição e justiça. Os 129 artigos da reforma eleitoral previam, entre muitas outras coisas: a formação de uma junta de qualificação composta pelo juiz de paz mais votado (seu presidente) e por mais oito membros eleitos dentre os eleitores da paróquia escolhidos na última eleição; a formação, pelo mesmo método adotado para a junta, da mesa paroquial, à qual caberia o reconhecimento da identidade dos votantes, a apuração dos votos, a decisão de quaisquer dúvidas (por maioria de votos) e a manutenção da ordem; a fixação dos horários e das datas do processo eleitoral para todo o Império; o modo pelo qual as cédulas deveriam ser entregues (pessoalmente, depositada em urna e sem necessidade de assinatura) assim como o modo de apurá-las; a lacração e a vigilância pública das urnas; os critérios de elegibilidade para os cargos de vereador, juiz de paz, eleitor, deputado provincial ou geral e senador; a inelegibilidade para o cargo de deputado provincial do presidente de província, do seu

\footnotetext{
${ }^{190}$ Anais da Câmara dos Deputados. 08 de abril de 1845. p. 514.

${ }^{191}$ Anais da Câmara dos Deputados. 07 de março de 1845. p. 90.
} 
secretário e do comandante de armas; o número fixo de deputados de cada província; a suspensão do recrutamento 60 dias antes e 30 após as eleições primárias; a proibição do arrumamento de tropas e de qualquer outra ostentação de força armada no dia da eleição primaria a uma distância inferior a uma légua do local de eleição; a decisão pelo governo central ou pelo presidente de província das dúvidas acerca da lei, sendo tal decisão publicada obrigatoriamente pela imprensa; a proibição dos eleitores votarem em parentes; a punição, por meio de multas, a quem descumprisse a lei. Apesar das mudanças do projeto original, mostrava-se vencedor o ímpeto daqueles que acreditavam na necessidade de se corrigir os vícios do processo eleitoral no Brasil: ao coibir os meios de fraude e violência durante período de eleições, a Lei de 1846 teve por objetivo regular a influência que os partidos em disputa poderiam exercer sobre os cidadãos.

De acordo com a historiadora Miriam Dolhnikoff, as reformas eleitorais que tiveram lugar no Brasil oitocentista guiaram-se pela "crença de que o governo representativo dependia da qualidade dos representantes escolhidos e esta qualidade, por sua vez, dependia da realização de eleições que garantissem a melhor escolha possível."192 Fraudes e violências - por parte dos governistas ou da oposição continuaram a existir durante todo o período monárquico; todavia, o esforço contra as irregularidades eleitorais também foi permanente. Como foi possível notar pela análise do debate acerca dos abusos eleitorais e da necessidade de reformas entre os anos de 1840 e 1846, o ideal de que a nação só seria legitimamente representada caso pudesse expressar livremente sua vontade se tornou vitorioso no Brasil imperial. Tendo em vista que a única decisão política direta dos cidadãos num regime representativo se dava por meio das eleições, a coerção desse direito se caracterizava como um dos maiores perigos contra a legitimidade do poder do Estado. Àqueles que disputavam os votos era dada a possibilidade de negociar com os votantes e eleitores; no entanto, tal negociação deveria ser feita dentro da legalidade.

Em torno do debate sobre as fraudes criou-se um consenso acerca dos meios legítimos de disputa eleitoral. As regras instauradas a partir dos ideais do regime representativo oitocentista possibilitaram que associações políticas transcendessem o que se considerava facciosismo e se estabelecessem como partidos regulares, que dentro da legalidade disputariam o poder no Império. As acusações que pesaram sobre os maioristas e a concomitante reforma eleitoral, conduzida por muitos dos acusados,

${ }^{192}$ Miriam Dolhnikoff. "Representação na monarquia brasileira”. Op. Cit. p. 47. 
estabeleceram parâmetros para disputas por votos entre grupos políticos rivais. O sistema político da monarquia constitucional brasileira se regularizava a partir da fixação de regras: as lutas entre facções se tornavam fato condenável e as elites políticas nacionais se transformavam em defensoras da legitimidade do processo eleitoral. Firmou-se entre 1840 e 1846 um campo legítimo de disputa entre partidos que se reconheciam sim como adversários, mas também como subordinados a uma só lei.

O estudo das petições mostrou que, para além de ser um ideal das elites, a busca pela legitimidade da representação política estava já na década de 1840 enraizada na sociedade governada. Como ficou demonstrado, a atividade peticionária de votantes, eleitores e autoridades locais contribuiu, em grande medida, tanto para o descrédito dos maioristas em 1841 quanto para a justificativa da proposta de reforma dos liberais em 1845. As petições estudadas neste capítulo, apesar de portarem queixas acerca de conflitos pontuais por votos, não se resumiam a isto somente: ao tratarem de um problema que dizia respeito à realidade política nacional, elas contribuíram para o debate sobre os modos de saná-lo. Irregularidades eleitorais cometidas em algumas localidades do Império se transformaram, no discurso dos peticionários, num assunto que tocava um dos mais importantes interesses da nação brasileira: a legitimidade de seus representantes. As petições populares foram capazes de ilustrar os legisladores sobre o fato de que as sangrentas lutas por poder entre facções locais e o envolvimento nelas de autoridades públicas poderiam fazer ruir a ordem política do Império. Evidentemente, as petições aqui estudadas partiram de grupos políticos que tinham interesses específicos no que dizia respeito às disputas eleitorais; no entanto, o modo pelo qual estes grupos conduziram suas críticas possibilitou que participassem da negociação parlamentar acerca do que seria, a partir de então, considerado como uma eleição legítima no Império. 


\section{CAPÍTULO 4. AS PRAÇAS COMERCIAIS E A INSTAURAÇÃO DO CÓDIGO COMERCIAL BRASILEIRO}

Certos grupos econômicos obtiveram grande influência política no Segundo Reinado. Dentre eles, as associações comerciais tiveram o maior destaque dentro da arena parlamentar. Devido à escassez de formação científica no Império, os negociantes de grosso trato se tornaram uma importante fonte de conhecimento econômico para os governantes da jovem nação. Notáveis comerciantes chegaram mesmo a ser eleitos para a Câmara dos Deputados, como foi o caso de dois eminentes presidentes da Associação Comercial do Rio de Janeiro, o Visconde de Mauá e Teófilo Benedito Ottoni. ${ }^{193}$ A luta pela aprovação do Código Comercial em 1850 - a partir de um projeto de lei idealizado em 1834 - representou a afirmação da força política desse grupo.

De acordo com José Murilo de Carvalho, o ano de 1850 estabeleceu um marco na história política brasileira, um momento decisivo para a definitiva implantação do Estado Nacional. Além da abolição definitiva do tráfico negreiro e da aprovação da Lei de Terras, naquele ano - explica o historiador - "foi publicado o Código Comercial que sistematizava a confusa legislação anterior, em boa parte de origem ainda colonial. Desde 1834 vinha o projeto se arrastando na Câmara e no Senado. Dele dependia, entre outras coisas, a regulamentação das sociedades anônimas, principais agentes do desenvolvimento econômico no capitalismo emergente." ${ }^{194}$ Ou seja, foi dentro de um quadro de redefinição institucional que os maiores comerciantes brasileiros da época viram aprovada uma legislação que por mais de uma década vinha sendo ansiada. $O$ Código, peça fundamental para o processo de modernização econômica do Império, ofereceu-lhes os instrumentos que lhes faltavam para a consolidação do seu poderio.

Durante as primeiras décadas da história nacional, o crescimento das exportações de açúcar, algodão e, sobretudo, de café fez com que o Estado Nacional se preocupasse cada vez mais com a regulamentação das atividades econômicas. O desenvolvimento do crédito e a ampliação do mercado interno tornaram mais urgente a necessidade de organização legal da atividade comercial. Somava-se a isso a percepção de que o país servia-se de um ordenamento jurídico obsoleto e que cabia aos governantes aperfeiçoá-lo. Até a década de 1840, devido à falta de um código que regulasse a atividade comercial, vigoraram as chamadas Leis da Boa Razão, instituídas

\footnotetext{
${ }^{193}$ Eugene Ridings. Business Interest Groups in Nineteenth-Century Brazil. Cambridge: Cambridge University Press, 1994. pp. 54-64.

${ }^{194}$ José Murilo de Carvalho. Op. Cit. p. 256.
} 
em meados do século XVIII quando o Marquês de Pombal era secretário de Estado do Império português. Elas se baseavam nas "leis dos povos cultos" e nas seculares tradições comerciais lusitanas: tais leis, no século XIX, foram responsabilizadas por trazer mais confusão do que soluções aos entreveros mercantis no Império brasileiro. ${ }^{195}$

Desde os tempos da Corte portuguesa no Rio de Janeiro havia preocupação estatal com a organização das atividades mercantis: a criação na Corte, em 1809, das Aulas de Comércio evidenciara este fato. $\mathrm{Na}$ visão dos governantes daquele tempo, o comércio brasileiro era confuso e atrasado; por isso, acreditava-se que as ciências econômicas deveriam ser difundidas urgentemente nesta parte do Império português. Já em 1789, José da Silva Lisboa, o futuro Visconde de Cairu, iniciara uma série de estudos sobre direito mercantil, tendo como foco os negócios luso-americanos; seus trabalhos continuaram com a Independência e, em 1834, sua influência, a partir da participação numa comissão nomeada pelo governo regencial, foi decisiva na elaboração do projeto do Código Comercial brasileiro. ${ }^{196}$

Ao lado da iminente figura de Cairu, na elaboração do projeto, estiveram Limpo de Abreu, Ignácio Ratton, Guilherme Midosi e Laurence Westin. Limpo de Abreu, que presidia a comissão, logo em 1833 foi substituído por José Clemente Pereira. De acordo com o historiador Julio Cesar Bentivoglio, todos estes idealizadores do Código eram homens vinculados a atividades comerciais: "Ratton era banqueiro e membro da Sociedade dos Assinantes da Praça do Comércio do Rio de Janeiro; Midosi era também capitalista e comerciante sediado no Rio de Janeiro; Westin, além de cônsul da Suécia no Brasil, era proprietário da casa de comércio Westin e Cia. e Cairu tinha fortes vínculos com os mercadores baianos, pois fora secretário da Mesa de inspeção em 1797 e depois deputado da Junta Comercial do Rio de Janeiro, em 1808. (...) Limpo de Abreu era genro de um importante fazendeiro e comerciante da região de Paracatu em Minas Gerais, que abastecia a Corte no Rio, e Clemente Pereira também foi relator do Código Comercial em 1847 [no Senado] e, a partir de 1851, presidiu o Tribunal de Comércio." ${ }^{197}$ Em 1836, depois de passar pelas mãos de juristas, o primeiro projeto do Código foi apreciado por uma comissão da Sociedade de Assinantes da Praça do Comércio do Rio de Janeiro, formada por comerciantes brasileiros e ingleses com

\footnotetext{
195 Julio Cesar Bentivoglio. "O Império das circunstâncias: o Código Comercial e a política econômica brasileira (1840-1860)". Tese de doutorado defendida no ano de 2002 na Universidade de São Paulo. pp. 118-119.

${ }^{196}$ Idem. Ibidem. pp. 119-121.

197 Idem. Ibidem. p. 132.
} 
importantes negócios na capital do Império. Os negociantes da Corte aprovaram a redação sem restrições. ${ }^{198}$

O projeto do Código, em primeiro lugar, visava restringir a profissão de comerciante: estariam excluídos do exercício do comércio menores não emancipados, presidentes provinciais, comandantes de armas das províncias, magistrados vitalícios, juízes municipais, juízes de órfãos, oficiais da fazenda, militares da primeira linha, membros dos corpos policiais, membros das corporações de mão-morta, clérigos e falidos. Com a finalidade de controlar a profissão, o projeto previa algumas obrigações aos comerciantes: ordenamento da contabilidade, da escrituração e dos livros necessários; registro frente às autoridades; balanço do ativo e do passivo; relação dos bens de raiz, dos bens móveis, das mercadorias, do capital, do crédito, das dívidas, das obrigações; etc. ${ }^{199}$

A mais importante medida prevista pelo projeto de 1834 era a criação dos Tribunais de Comércio. Estes seriam estabelecidos primeiramente na Corte, em Salvador e no Recife - cidades mais ricas e principais portos de exportação do Império naquele momento - sendo que as demais províncias ganhariam seus Tribunais próprios conforme a necessidade se afigurasse. Os Tribunais seriam compostos por um presidente letrado, por deputados comerciantes (seis no Rio de Janeiro e quatro nas demais cidades), por suplentes, por um fiscal e por um desembargador em exercício efetivo na respectiva província. O presidente e os fiscais seriam nomeados pelo imperador ao passo que os deputados e os suplentes seriam eleitos por eleitores comerciantes a cada quatro anos. Para ser qualificado a exercer o cargo de deputado do Tribunal de Comércio era necessário possuir capital mínimo de 40 contos de réis (40:000\$000), mais de 30 anos de idade e mais de cinco anos de experiência no comércio: sendo assim, os cargos ficavam restritos aos negociantes de grosso trato (lembre-se aqui que, pela Constituição de 1824, a renda anual exigida para a elegibilidade ao cargo de deputado geral era de 400\$000). ${ }^{200}$

Dentre as principais funções previstas para os Tribunais de Comércio estavam: $1^{\text {a) }}$ matricular comerciantes, corretores, agentes de leilão, trapicheiros, administradores e administradores de armazéns; $2^{\mathrm{a}}$ ) expedir títulos; $3^{\mathrm{a}}$ ) rubricar os livros das casas comerciais; $4^{\mathrm{a}}$ ) nomear e juramentar intérpretes do comércio; $5^{\mathrm{a}}$ ) inspecionar trapiches e

\footnotetext{
${ }^{198}$ Idem. Ibidem. p. 133.

${ }^{199}$ Idem. Ibidem. pp. 147-148.

${ }^{200}$ Idem. Ibidem. pp. 159-160.
} 
alfândegas; $6^{\text {a }}$ ) controlar a atividade de corretores e agentes de leilão; $7^{\mathrm{a}}$ ) nomear administradores para heranças de pessoas que falecessem sem testamento; $8^{a}$ ) destituir liquidantes de sociedades mercantis dissolvidas; $9^{a}$ ) ordenar o registro das embarcações brasileiras destinadas ao comércio ultramarino; e, mais importante, $10^{\mathrm{a}}$ ) arbitrar conflitos entre os principais negociantes do Império - quando as partes litigantes não chegassem a um acordo amigável por si mesmas, deveriam dirigir petições ao Tribunal para que este procedesse ao arbitramento. Compostos por homens com verdadeira experiência no assunto, estes órgãos supostamente resolveriam, com a maior rapidez e eficácia possíveis, as disputas que entravavam o bom andamento da atividade comercial no Brasil. ${ }^{201}$ Aos Tribunais de Comércio - e, conseqüentemente, aos negociantes de grosso trato - ficaria delegada grande influência sobre as questões mercantis no Brasil.

Após ser entregue ao corpo legislativo do Império, o projeto do Código Comercial tramitou em meio às idas e vindas que o regime político brasileiro sofreu durante as décadas de 1830 e 1840. Seu itinerário entre as diversas comissões parlamentares e comissões externas foi complexo. Somente no ano de 1850, quando uma comissão parlamentar - presidida por Eusébio de Queiroz e composta por José Clemente Pereira, Caetano Alberto Soares, José Thomas Nabuco de Araújo, Francisco Ignácio de Carvalho Moreira e Irineu Evangelista de Souza (o Barão de Mauá) - foi nomeada especialmente para resolver a questão, o Código Comercial foi incorporado à legislação brasileira. ${ }^{202}$ Conforme José Murilo de Carvalho aponta, o gabinete conservador agiu de forma muito eficaz no ano de 1850 ao aprovar uma série de medidas que por muito tempo estavam sendo adiadas e que contribuiriam para a modernização econômica do Império. ${ }^{203}$ Contudo, algo além da competência de homens como Eusébio, Clemente ou Mauá contou para o sucesso da aprovação do Código Comercial. Durante a década de 1840 os negociantes do Império adotaram competentemente uma estratégia que fez sua demanda presente no seio da representação nacional: o exercício do direito de petição.

Com amplo acesso ao centro de poder, os representantes das principais praças de comércio do Império tiveram papel fundamental na aprovação dessa lei que lhes afetava diretamente. Como já apontou o historiador Eugene Ridings, "important petitions were sent to the Imperial Parliament as well as to the Emperor. To ensure their favorable

\footnotetext{
${ }^{201}$ Idem. Ibidem. pp. 160-161.

${ }^{202}$ Idem. Ibidem. pp. 122-129.

${ }^{203}$ José Murilo de Carvalho. Op. Cit. pp. 256-257.
} 
reception, it was necessary to work through individual parliamentarians. Much of the lobbying efforts of business interest groups were aimed at cultivating these politicians. Business interest groups directed most of their attention toward members of the elected Chamber of Deputies rather than the appointed Senate, perhaps because the former was more active in initiating legislation." 204 Buscarei mostrar no presente capítulo que, no caso da aprovação do Código Comercial, a influência das praças de comércio sobre a Câmara foi decisiva: ao estabelecer vínculos com os representantes da nação e ao utilizar das petições como meio de expressar sua demanda, as associações comerciais influenciaram a atividade legislativa do Império em benefício da aprovação do projeto idealizado em 1834 por Cairu e por outras importantes figuras ligadas aos negociantes de grosso trato.

No ano de 1840, 54 negociantes da praça comercial da Bahia assinaram uma petição dirigida à Câmara dos Deputados na qual reclamavam que sua atividade continuava a ser regulada por legislação estrangeira, pouco adaptada aos usos e costumes brasileiros e aberta a arbitrariedades. Segundo eles, o direito civil era inadequado ao comércio, que exigia conhecimentos específicos: somente um corpo jurídico versado nas ciências e nas práticas econômicas seria capaz de decidir sobre questões de direito comercial. Não à toa, tal prática estava sendo a cada dia mais utilizada pelas nações cultas, onde os mais destacados negociantes compunham tribunais especiais nos quais apenas se tratava de comércio: França, Portugal e Espanha evidenciavam esta realidade. A situação do comércio brasileiro dava lugar a falências fraudulentas e os credores não tinham a quem recorrer nos casos em que eram enganados por pessoas de má fé - os resultados de tal cenário só poderiam mesmo ser nefastos: "quem não vê que a desconfiança substituindo a franqueza e boa fé, eixo capital da máquina mercantil, faz aferrolhar os capitais, paralisar o fácil giro do comércio, e a pública prosperidade recebe uma ferida de fatais conseqüências?"205 Não somente os negociantes, mas toda riqueza da nação era afetada pela falta de um código específico para o comércio no Brasil.

Naquele mesmo ano, representantes da Associação Comercial de Pernambuco dirigiram uma petição à Câmara lamentando o fato de que decidir as questões mercantis nos tribunais comuns com base em leis estrangeiras se constituía numa anomalia

\footnotetext{
${ }^{204}$ Eugene Ridings. Op. Cit. p. 63.

205 Petição dos negociantes da praça da Bahia. 15 de junho de 1840. Centro de Documentação e Informação. Arquivo da Câmara dos Deputados. Brasília. Consultado em fevereiro de 2009.
} 
vergonhosa, já que nem tais tribunais tampouco tais leis eram suficientes para dar garantias aos negociantes brasileiros. Sustentar, como alguns sustentavam, que tribunais especiais para fins mercantis seriam um privilégio anticonstitucional era uma forma de fazer subsistir arbítrios, era um argumento fútil e destituído de razão: desfilando erudição, a petição dos pernambucanos citava a existência de tribunais comerciais especiais desde a Antigüidade - Demóstenes, Xenofonte, Bartholo e Baldo teriam sido os primeiro idealizadores de um direito especial para o comércio. Dizia ainda o documento que, para se comprovar a positividade de tribunais comerciais, bastava ao legislador constatar que "as mesmas Nações modernas, cujo sistema político é o Governo Representativo, ou misto, como o nosso, têm juízes e tribunais especiais para as causas mercantes." No Brasil, inclusive, já existiam judicaturas especiais, como para os órfãos, e elas não constituíam, de forma alguma, privilégios anticonstitucionais. Os peticionários reforçavam seu pedido com um argumento muito em voga no mundo ocidental durante o século XIX:

o Comércio, Senhores, deve ser protegido e animado pelo governo; por isso que é o motor da civilização e riquezas, dá utilidade não só aos particulares, como ao bem público do Estado e faz [com] que as Nações e seus Governos se tornem poderosas; não deverá merecer seus juízes especiais, que imbuídos nas máximas e usos mercantis nacionais, compreendam bem a legislação relativa e dêem com justiça breve expediente que ocorrerem sobre os pactos e contratos comerciais?

Argumentavam ainda os negociantes pernambucanos que as obras de Boucher na França e de Cairu no Brasil comprovavam de forma clara e racional que o direito civil e o direito comercial se constituíam de modos distintos e, por isso, não deviam andar misturados, a menos que se quisesse que toda a sociedade pagasse elevado preço. Sendo assim, a Associação fechava sua petição conclamando os representantes da nação à ação:

é por isso que os peticionários confiam que serão atendidos; e certo, Senhores, o Poder Legislativo decretando na presente sessão o Código Comercial para subir à sanção imperial, cobrir-se-á de glória e transmitirá à posteridade um monumento eterno de seu patriotismo. ${ }^{206}$

No ano de 1841, mais uma vez os comerciantes baianos decidiram peticionar aos representantes da nação: desta vez era a junta diretora da Associação Comercial da Praça da cidade da Bahia que escrevia a favor da aprovação do Código Comercial; uma das assinaturas desta petição era do deputado geral José Alves da Cruz Rios. Segundo

\footnotetext{
${ }^{206}$ Petição da Associação Comercial de Pernambuco. 21 de maio de 1840. Centro de Documentação e Informação. Arquivo da Câmara dos Deputados. Brasília. Consultado em fevereiro de 2009.
} 
os peticionários, a falta de um código próprio para o comércio teria levado muitos juízes, esmagados pela amplitude de suas funções, a julgarem de formas diversas casos semelhantes - tal precedente teria dado chances à má fé de alguns que se beneficiavam de falências fraudulentas. À custa da riqueza alheia, homens oportunistas faturavam e a demora dos tribunais comuns, junto de sua falta de especialização, apenas dava mais força aos golpistas. As possíveis imperfeições que pudessem existir no projeto de 1834 seriam corrigidas pela prática: a simples existência do Código seria já um passo importante para se regularizar e assegurar os negócios nacionais. A associação baiana citava em sua petição os apelos feitos por outros grupos de negociantes brasileiros e dizia confiar na ação dos representantes da nação: "fora ousadia, além de ofensa a sabedoria e luzes que brilham nesse recinto, se esta junta ainda se demorasse a provar a necessidade de um Código Comercial e o bem que resulta à Nação de se aprovar um corpo de leis a respeito.",207

Poucos meses depois, mais uma petição chegava à Câmara com o mesmo objetivo:

a Comissão da Praça de Comércio do Rio de Janeiro, acompanhando a representação da junta diretora da Associação Comercial da Praça da Bahia, em que expõe a necessidade de se adotar o projeto do Código de Comércio, trairia sua missão deixando de manifestar seus mais ardentes votos que são em tudo idênticos aos da Associação Comercial da Bahia.

Havia, declaradamente, um esforço conjunto dos órgãos de comércio das mais ricas cidades do Império para influenciar os representantes da nação no sentido da aprovação do projeto elaborado em 1834. Não por acaso, os mesmos argumentos eram repetidos constantemente:

a mencionada representação indica, bem que sucintamente, a origem da maior parte dos males que, afligindo o Corpo do Comércio, tolhem seu progresso e desenvolvimento, e mostra a necessidade tão geralmente sentida de uma legislação peculiar e adaptada às circunstâncias, que arranque do caos em que existe uma das mais importantes classes da sociedade, condigna de melhor sorte.

A idéia de que uma legislação específica era necessária para a melhoria das condições do comércio era generalizada entre as associações comerciais que escreviam à Câmara dos Deputados. Estava clara ainda em suas petições a idéia de que a interferência de um órgão jurídico oficialmente estabelecido na atividade comercial

207 Petição da Associação Comercial da Praça da cidade da Bahia. 02 de junho de 1841. Centro de Documentação e Informação. Arquivo da Câmara dos Deputados. Brasília. Consultado em fevereiro de 2009. 
traria benefícios para toda a comunidade nacional, e não somente aos negociantes: a ação do poder público deveria colocar ordem no caos reinante no país como um todo esta seria, segundo os diversos peticionários, a função central do legislador. As nações civilizadas, segundo eles, haviam pressentido a necessidade de uma legislação e de tribunais especiais para o comércio: o Brasil não poderia permanecer de fora da tendência mundial.

Senhores! A necessidade deste [Código] é tão gravemente reconhecida que não se atrevem a contestá-la nem mesmo aqueles a quem têm favorecido o caos em que achamo-nos. Um código que defina claramente os direitos e deveres de cada um, que sirva de norte a todos, que garanta ao homem honesto o fruto do seu trabalho e que infunda temor ao homem imoral, em suas fraudulentas empresas e maquinações, é sem dúvida a maior e mais urgente necessidade do Corpo de Comércio.

Somente o flagrante descaso dos governantes podia explicar que o comércio brasileiro continuasse imerso em irregularidades, posto que os representantes da nação já tinham em mãos uma forma de confirmar sua função civilizadora da sociedade. Continuavam os comerciantes do Rio:

Senhores! O projeto do Código Comercial cuja aprovação solicitamos é obra de homens doutos e as emendas e correções que se lhe fizeram são o resultado de escrupuloso exame incumbido a homens inteligentes e práticos na matéria.

Esta Comissão lisonjeia-se com a esperança de que não será perdido o fruto de tão patrióticos trabalhos e confia que o Brasil não será a última das nações na fruição dos benéficos efeitos de um Código Comercial. ${ }^{208}$

A ação legislativa devia impor a ordem racional sobre a desordem reinante; o parlamento imperial teria o poder, na concepção das associações comerciais, de equiparar a nação brasileira às irmãs mais avançadas no caminho da civilização.

Em 1842 apareceu mais uma petição da Associação Comercial de Pernambuco e, novamente, os argumentos se repetiram: os embaraços, a lentidão dos processos, a má fé, as falências fraudulentas, a experiência das nações civilizadas etc. A estratégia adotada pelos comerciantes era deixar sempre aceso o debate acerca da necessidade do Código por meio das petições, esperando que assim, um dia, os seus representantes tomassem o problema para si. Os negociantes pernambucanos justificavam sua segunda petição dentro de um período de 3 anos:

os peticionários, Augustos e Digníssimos Representantes da Nação, na sessão de quarenta vos apresentavam suas súplicas para que nela satisfizesse

\footnotetext{
${ }^{208}$ Petição da Comissão da Praça de Comércio do Rio de Janeiro. 04 de agosto de 1841. Centro de Documentação e Informação. Arquivo da Câmara dos Deputados. Brasília. Consultado em fevereiro de 2009.
} 
e subisse à sanção Imperial o Código Comercial que está proposto à discussão; e se então o estado do comércio do Brasil clamava por esta salutar providência, se já então os peticionários receavam o risco de suas fortunas, se então já os pleitos judiciais eram sem número, as bancarrotas formigavam, se já não se conheciam garantias, se finalmente o crédito e boa fé, que é moeda comercial, estavam a definhar, hoje essas circunstâncias têm engravescido por maneira que desalenta de todo ao negociante probo: e se esta Augusta Assembléia não se dignar atender às súplicas que respeitosamente as Associações Comerciais têm apresentado, dando o único remédio que pode vencer o mal, veremos acabarem as casas comerciais que ainda existem e só aventureiros negociarão em pura perda das Rendas Públicas e das riquezas e da indústria do país. ${ }^{209}$

Assim como já haviam colocado baianos, fluminenses e mesmo os próprios pernambucanos, mais do que um mal aos negociantes, a falta de um código representava grandes males a todo o país. A insistência dos comerciantes surtiu efeito no ano de 1843, quando finalmente o tema do Código Comercial foi discutido pela Câmara dos Deputados. No dia $1^{\circ}$ de julho apareceu uma indicação do deputado fluminense João Manoel Pereira da Silva para que

a comissão do código do comércio, nomeada por esta Câmara, exponha à casa o resultado de suas fadigas e, com urgência, promova o andamento e satisfação de uma necessidade tão clamorosa como a de uma lei mercantil, que fixe a legislação e defina os crimes comerciais que possam ser punidos pelos competentes tribunais afim de terminar esse terrível caos de inteligências, interpretações e opiniões sobre tais matérias, e a continuação de bancarrotas que entre nós se sucedem com escândalo quase todos os dias. $^{210}$

Foi o mesmo deputado que, no dia 19 de julho de 1843, antes mesmo do parecer da comissão ser apresentado, trouxe diante de seus pares duas petições de comerciantes do Rio de Janeiro. Disse ele ao introduzi-las no plenário:

tendo eu a honra de ser pelos dignos membros da comissão da praça incumbido de apresentá-las, julgo do meu dever observar à Câmara que todas as razões alegadas pelos signatários das mencionadas representações são verdadeiras e justíssimas; que o Brasil, destinado pela sua posição geográfica a ser grande império comercial, não pode desenvolver todas as suas forças e toda a sua energia enquanto durar a falta de uma legislação puramente mercantil, que estabeleça princípios certos e regras determinadas que dirijam as transações, um tribunal excepcional para os julgamentos e a definição exata e rigorosa execução de todos quantos fatos constituem crimes comerciais: no estado atual do país, quando quase que não existe legislação especial do comércio, quando um ou outro alvará vigente não está ao nível da civilização, quando nos julgamentos dos magistrados não há uniformidade, tudo é confusão, tudo anarquia; às nossas Câmaras [Câmara dos Deputados e Senado] cumpre remover este mal. É tempo que desta

\footnotetext{
${ }^{209}$ Petição da Associação Comercial de Pernambuco. 02 de abril de 1842. Centro de Documentação e Informação. Arquivo da Câmara dos Deputados. Brasília. Consultado em fevereiro de 2009.

${ }^{210}$ Anais da Câmara dos Deputados. 01 de julho de 1843. p. 13.
} 
legislatura saia uma lei que contenha interesse real, que satisfaça os votos e as necessidades clamorosas do país. Seja essa lei o Código Comercial aprovado em globo e por aclamação, e que vá demonstrar ao público que a representação nacional é digna da sua missão. Tratemos, nos poucos tempos que nos restam de sessão, de medidas úteis e necessárias e não desperdicemos os nossos trabalhos sem proveito do país. ${ }^{211}$

Note-se que o deputado fluminense se baseava na premissa, já apresentada pelas petições, de que o Código Comercial se constituía como "uma lei que contenha interesse real, que satisfaça os votos e as necessidades clamorosas do país." Somente por meio desta argumentação Pereira da Silva podia legitimar seu posicionamento perante a maioria de seus pares, somente assim ele podia discutir a demanda dos negociantes de grosso trato com os demais legisladores e defender a aclamação do projeto idealizado em 1834. Abraçada por um representante, a causa dos peticionários adentrava o debate parlamentar.

Aquela não era a primeira vez que a Comissão da Praça de Comércio do Rio de Janeiro escrevia à Câmara; porém, agora sua petição era apresentada e defendida por um membro do parlamento. Sua súplica era, diziam os peticionários em acordo com Pereira da Silva, apenas eco "do clamor geral e cotidiano contra o progresso da imoralidade e gradual míngua de boa fé e confiança, que são as molas reais do trato mercantil." Tal clamor havia se generalizado devido à evidente precariedade das condições mercantis nacionais: "Senhores! A existência do Brasil, topograficamente marítimo e essencialmente agrícola e comerciante, é conhecidamente precária, com míngua de leis ou com leis defeituosamente incertas.” Mais à frente, os peticionários conclamavam os deputados à ação: "Senhores! Satisfazendo aos votos do país, e com especialidade aos do Corpo do Comércio, certamente digno da vossa contemplação, dareis uma brilhante prova do vosso patriotismo, e adquirireis novo título à gratidão nacional." 212 Mais uma vez se afirmava que todo o Brasil seria beneficiado pela promulgação do projeto de 1834 uma vez que a classe dos negociantes obteria mais segurança para continuar seus afazeres e para contribuir com o engrandecimento geral da nação: tal era a mensagem da Comissão da Praça de Comércio do Rio de Janeiro e de todo o resto da elite mercante brasileira.

\footnotetext{
${ }^{211}$ Anais da Câmara dos Deputados. 19 de julho 1843. p. 290.

${ }^{212}$ Petição da Comissão da Praça de Comércio do Rio de Janeiro. 14 de julho de 1843. Centro de Documentação e Informação. Arquivo da Câmara dos Deputados. Brasília. Consultado em fevereiro de 2009.
} 
Anexo à petição da Comissão vinha um documento que supostamente representava as demandas de todos os negociantes da Corte; estes, por sua vez, não faziam mais do que repetir os argumentos apresentados pelas petições anteriores. Segundo eles, a falta de legislação comercial adequada no Brasil dava espaço para vexames e abusos; os juízes e os tribunais comuns, por mais bem intencionados que fossem, não tinham competência para decidir com prontidão e acerto os litígios de comércio interno e externo; as leis pátrias eram obscuras e as leis estrangeiras causavam confusão; o caos da jurisprudência representava o flagelo maior que secava o comércio nacional. O corpo legislativo demonstrara, segundo os peticionários, boa vontade ao nomear comissões para redigir e, posteriormente, analisar o projeto, mas ainda não havia tido a oportunidade de discuti-lo e votá-lo: tal demora acarretava prejuízos para a fortuna pública e para o processo de civilização do Império. Nada de verdadeiramente novo existia nos argumentos apresentados por esta petição. No entanto, sua grande força vinha logo abaixo dos argumentos: as 153 assinaturas dos mais destacados comerciantes estabelecidos na capital do Império comprovavam o quanto a aprovação do Código era desejada pelo grande comércio do país. ${ }^{213}$

Seguindo a apresentação das petições por Pereira da Silva, o deputado mineiro José Cesário de Miranda Ribeiro tomou a palavra: "como membro da comissão especial, posso informar à Câmara que os trabalhos acerca desta matéria estão concluídos. O Código está na imprensa." 214 Iniciava-se, então, o mais importante debate acerca da aprovação do Código Comercial na Câmara dos Deputados. No dia 29 de agosto de 1843, a comissão parlamentar encarregada de revisar o projeto de 1834 entregou seu parecer aos representantes da nação:

como no entender das comissões reunidas o novo projeto, suposto não possa dizer-se obra perfeita, pode ser adotado sem grave inconveniente na prática, deixando-se à urgente necessidade que existe de estabelecer regras certas que regulem a decisão das questões comerciais, sujeitas até hoje ao livre arbítrio que a Lei de 18 de agosto de 1769 deixou aos julgadores de recorrerem às leis econômicas, mercantis e marítimas das nações cristãs, iluminadas e polidas; considerando também que petições dos comerciantes de diversas praças do Império têm sido apresentadas a ambas as câmaras, pedindo medidas legislativas que ponham termo aos males que o comércio padece por falta de um código comercial; e observando finalmente que uma discussão por artigos fora absolutamente impraticável.

É a comissão de parecer, de acordo com a comissão da câmara dos Srs. senadores, que o novo projeto redigido pelas duas comissões se discuta em

\footnotetext{
${ }^{213}$ Petição dos negociantes da praça do Rio de Janeiro. 26 de maio de 1843. Centro de Documentação e Informação. Arquivo da Câmara dos Deputados. Brasília. Consultado em fevereiro de 2009.

${ }^{214}$ Anais da Câmara dos Deputados. 19 de julho de 1843. p. 290.
} 
globo, aprovando-se ou rejeitando-se, como parecer à sabedoria desta Augusta Câmara. ${ }^{215}$

As petições das associações comerciais do Rio, de Salvador e do Recife haviam cumprido sua missão de iniciar o debate parlamentar. Caberia, a partir de então, aos aliados do comércio de dentro da Câmara fazer com que o projeto de 1834 fosse aprovado pelos demais legisladores. Entretanto, havia um fator complicador: o regulamento da Câmara dos Deputados exigia que projetos de decreto, como o do Código, passassem por três discussões, compostas cada uma por 12 discursos - a primeira discussão serviria para a aprovação ou recusa geral do projeto, tal qual ele se apresentasse; a segunda serviria para o exame de cada um dos artigos; e, finalmente, a terceira versaria sobre a aprovação ou recusa do projeto como um todo, incluindo as modificações resultantes das emendas propostas no decorrer das discussões precedentes. Como o projeto do Código se compunha de nada menos do que 947 artigos, sua discussão regular inviabilizaria a urgente e integral aprovação que pediam os comerciantes. A missão de Pereira da Silva e dos demais aliados do comércio passava a ser aprovar a indicação da comissão parlamentar pela discussão em globo do projeto.

Logo, na contramão da pressa dos aliados do comércio, se colocou o deputado baiano Ângelo Muniz da Silva Ferraz:

o Código atual dizem-me que foi proposto em duas sessões, foi revisto por uma nobre comissão, não só desta câmara como do Senado, foi sujeito a uma comissão do comércio, a um negociante esclarecido, foi sujeito a advogados, todas pessoas entendidas na matéria; todas essas pessoas deram o seu parecer; mas nem por isso deve a Câmara deixar o direito de examinar este trabalho. Pois houve tempo para se dar ao Sr. Louzada e a outros advogados do foro desta Corte, deu-se-lhes o direito de examiná-lo, e não se quer dar tempo a um deputado que tem de votar e que tem o direito de o examinar para bem votar, que é responsável pelo seu voto? ${ }^{216}$

A partir deste discurso, duas posições se polarizaram na Câmara: um grupo dizia que o Código estava pronto e não deveria ser submetido pela Câmara a uma discussão detalhada; o outro concordava que o Código era uma necessidade, mas exigia que fosse devidamente debatido pelos representantes da nação. Não obstante o fato da legislatura que se iniciou em 1843 ter sido eleita após a dissolução de 1842 e ser dominada por aliados da política do Regresso, como era o caso do baiano Ferraz e também do fluminense Pereira da Silva, houve então grande divergência acerca do modo pelo qual se aprovaria o projeto de 1834. O argumento central de Ferraz e de seus aliados era que

\footnotetext{
215 Anais da Câmara dos Deputados. 29 de agosto de 1843. p. 920.

${ }^{216}$ Anais da Câmara dos Deputados. 30 de agosto 1843. p. 938.
} 
a atividade legislativa não poderia jamais prescindir do debate e que era obrigação dos deputados fazer o possível para que o projeto fosse devidamente analisado antes de ser imposto à população brasileira. A resposta à argumentação de Ferraz foi imediata. O deputado Manoel Joaquim Carneiro da Cunha, membro de uma das mais ricas famílias do norte do Império e considerado um dos fundadores do partido conservador em Pernambuco, ${ }^{217}$ assim se pronunciou:

minha opinião portanto é que se aprove o Código sem discussão. E de certo, de que serve esta terceira discussão? Para emendar o projeto? Talvez assim o vamos transtornar com uma só discussão, e com emendas pouco refletidas. Não são os corpos coletivos os mais próprios para discutir uma lei desta natureza. Votemos este Código tão reclamado pelo comércio do Brasil; o tempo nos mostrará os defeitos que devemos corrigir: se os nobres deputados me mostrarem em que parlamento de país algum constitucional se tenha discutido códigos como o de que se trata, eu me oporei ao parecer da mesa: todavia eu por ele votaria se a sessão não estivesse próxima a encerrar-se, e como muitos negociantes da Paraíba e de Pernambuco me mostraram a urgente necessidade desta lei, por isso é que eu prefiro ser aprovada por uma resolução para evitar que a emenda seja pior. ${ }^{218}$

Diante daqueles que exigiam uma discussão detalhada, Carneiro da Cunha declarado aliado dos negociantes de Pernambuco e da Paraíba, províncias cujas atividades econômicas eram ligadas - rejeitava a necessidade de qualquer discussão, fosse ela feita por partes, fosse em bloco. Barrar qualquer discussão era uma estratégia pensada para manter o projeto íntegro, sem alterações, de acordo com o que haviam idealizado Cairu e os importantes negociantes da década de 1830. O deputado pernambucano visava, ao defender o parecer da comissão, evitar que interesses estranhos aos do grande comércio brasileiro deturpassem ou mesmo inviabilizassem a aprovação do Código.

Evidentemente, a pressa demonstrada pelos aliados das praças gerou descontentamento - eis como o também pernambucano Urbano Sabino Pessoa de Mello se colocou logo após o discurso de seu comprovinciano:

não considero muito essencial a questão se o Código deve ser discutido por título, por capítulos ou por parte, ou se deve ser discutido em globo: o mais essencial, o que mais importa é que não seja ele discutido este ano; é preciso que se nos dê tempo para formar a respeito dele o nosso juízo, para então deliberar se devemos adotar ou rejeitar o projeto. Talvez mesmo fosse conveniente, talvez venha eu mesmo a concordar que haja só uma discussão; talvez concorde que nessa discussão não se ofereçam emendas; mas é

\footnotetext{
${ }^{217}$ Revista do Instituto Archeologico e Geographico Pernambucano. Quarto ano, tomo segundo, número 13. Recife: outubro de 1866. p. 348.

218 Anais da Câmara dos Deputados. 30 de agosto 1843. p. 939.
} 
preciso que se nos dê tempo para deliberar se devemos adotar ou rejeitar o projeto. $^{219}$

Sabino, um dos fundadores do partido praieiro e adversário de Carneiro da Cunha em Pernambuco, exigia mais tempo para que os representantes da nação pudessem pesar os pontos positivos e negativos do projeto. Consciente do fato de que discutir 947 artigos seria inviável, o oposicionista pernambucano adotava uma nova estratégia: postergar a discussão para o ano seguinte, dando assim tempo para que aqueles que não se alinhavam às praças comerciais mais importantes do país fossem capazes de analisar o projeto e de elaborar suas críticas. Ao contrário daqueles que tinham pressa em ver o Código Comercial aprovado, Sabino chegava mesmo a duvidar da relevância das opiniões expressas pelos comerciantes brasileiros:

não é muito necessário apelar para a experiência [dos comerciantes nacionais]; a experiência nós temos de nações civilizadas, e creio que o nosso país a este respeito, que as nossas praças comerciantes pouca diferença podem fazer, porque não há essa especialidade de comércio no Brasil que exija uma legislação especial aplicada às nossas circunstâncias; tanto assim que, segundo uma leitura rápida do Código do Comércio, não vejo nele disposição própria do Brasil; são as mesmas que se encontram nas nações civilizadas: ali não há nada de especial. ${ }^{220}$

A importância política do interesse mercantil era questionada na fala de Sabino e, ainda que ele não contestasse a necessidade do Código em si, contestava a urgência de se adotar o projeto tal qual se apresentava naquele momento. Neste sentido, se unia ao baiano Ferraz, seu adversário em outras matérias.

O fluminense Pereira da Silva, líder dos aliados às praças mercantis na Câmara, não se calou perante a contestação do pernambucano:

sinto não concordar com o ilustre membro; reconheço que podem haver defeitos nesse processo de aprovação em globo; é um dos males inerentes às obras humanas que não podem sair nunca perfeitas; maiores males, porém, entendo eu, resultam de todos aqueles grandes projetos de leis que os corpos deliberantes miúda e longamente discutem: cada Sr. deputado quer provar que estudou a matéria, colhe algumas idéias dos publicistas que a respeito escreveram, deseja discutir, emendar, para melhor manifestar sua inteligência ou amor próprio: há logo nas votações todas essas transações que se usam nos parlamentos; o orgulho de cada um quer ser satisfeito, que, passando suas emendas, se demonstra a influência do orador: destes mesquinhos interesses que se reúnem, e mesmo da falta de atenção que os corpos deliberantes prestam às discussões quando duram algum tempo; deste cansaço que dos espíritos se apodera, o que resulta? É que a obra que devera ser homogênea e sistemática, a obra que convinha ter todas as suas partes concordes, todas as suas relações unânimes e paratadas (apoiados), perde o

${ }^{219}$ Ibidem. p. 939. 
sistema que presidiu à sua confecção (apoiados), não tem a harmonia precisa para ligar suas diversas disposições. ${ }^{221}$

Colocando a atividade deliberativa como uma luta entre "mesquinhos interesses", Pereira da Silva deixava explícito que, no caso do Código Comercial, preferia a opinião dos poucos e ilustrados elaboradores do projeto à ponderação dos deputados do Império. Em suas próprias palavras:

confio mais na boa redação e disposição de uma lei feita por poucos indivíduos, mas que sejam entendidos, ilustrados nas matérias que se discutem, do que em uma lei feita por muitos: é por isso que eu desconfiarei mais em contrário ao nobre deputado a quem me refiro [Sabino] de uma lei discutida parcialmente em uma Câmara de deputados, do que de uma lei feita por poucos homens, porém de capacidades e luzes, e que seja votada em globo e de confiança pelo corpo legislativo. ${ }^{222}$

Segundo Pereira da Silva, a melhor legislação de seu tempo era a francesa; legislação esta que, composta por um restrito grupo de grandes homens a serviço do maior deles, Napoleão, se constituía num verdadeiro "monumento de glória". ${ }^{223} \mathrm{Se}$ opondo frontalmente à opinião de Sabino no que tangia à aprovação do projeto do Código Comercial, o deputado fluminense estava seguro de que, naquele caso, a opinião dos peticionários deveria determinar a ação dos representantes da nação:

felizmente o nobre deputado me parece o único indivíduo que não acredite na urgente e imediata necessidade desta medida, e que pense que se pode demorar sua adoção, todos os nobres deputados que falaram, ainda mesmo contra o parecer, reconheceram a urgente necessidade de uma legislação comercial para o Império, ouviram os clamores poderosos da sociedade brasileira. $\mathrm{O}$ nobre deputado me parece o único que entende que nós poderemos por hora prescindir disto. $\mathrm{O}$ meu honrado amigo, permita-me que lhe diga, está em completa contradição com o povo todo do Brasil, porque já de todas as Assembléias Provinciais do Império, já dos corpos do comércio das diferentes praças do Brasil, já de muitas outras associações existentes entre nós, tem vindo ao corpo legislativo representações as mais enérgicas, exigindo a aprovação de um código de comércio.

(...) De todas as partes do Brasil têm vindo a esta casa urgentes reclamações de um código de comércio; há bem poucos dias eu tive a honra de apresentar uma representação da praça do Rio de Janeiro, que tem representado por diversas vezes; se há necessidade pública bem provada é esta; o povo todo a sente, e a satisfação de tal necessidade não deve tardar, se é que nós temos em vista o bem público... ${ }^{224}$

O deputado fluminense foi interrompido por uma voz provocativa que veio do plenário: "constituiu-se patrono do Código." A ironia, porém, não perturbou Pereira da

\footnotetext{
${ }^{221}$ Ibidem. pp. 941-942.

222 Ibidem. p. 942.

${ }^{223}$ Ibidem. p. 942.

${ }^{224}$ Ibidem. p. 943.
} 
Silva, que respondeu: "sou muito fraco, mas tenho muita honra em cooperar com todas as minhas forças para conseguir esse grande bem para o meu país; tenho muita honra em exprimir aqui as necessidades do comércio brasileiro, porque ele merece toda a atenção e importância."225 O deputado fluminense declarava-se um aliado das associações comerciais na Câmara; no entanto, justificava sua posição caracterizando a demanda pelo Código como resultado dos "clamores poderosos da sociedade brasileira". Utilizando-se da força política que adquiria a atividade peticionária na década de 1840, o deputado fluminense transfigurava, diante dos demais legisladores, o interesse de uma classe específica no interesse de toda a nação.

Em respostas à perspicaz argumentação de Pereira da Silva, o deputado paulista Joaquim José Pacheco assim se colocou:

\begin{abstract}
persuado-me que se os nobres deputados pensarem bem na matéria hão de convir conosco que a Câmara dos Srs. Deputados carece de algum tempo para meditar seriamente sobre assunto tão importante quanto difícil. É verdade, Sr. presidente, que há um clamor da parte do comércio do país, exigindo quanto antes um código; mas quando o comércio e o país assim se pronunciam, não é porque queiram um código bom ou mau; o que eles querem é um código que estabeleça regras fixas, que marque os direitos e obrigações comerciais, a maneira por que os juízes devem julgar as causas, e que enfim termine essas dúvidas e lacunas que se observam na legislação existente; se em lugar de um código assentado nas sólidas bases da justiça aparecer um mal confeccionado, que deixe em pé as mesmas dúvidas, e multiplique outras, certamente o comércio e o país terão de clamar ao corpo legislativo. ${ }^{226}$
\end{abstract}

Pacheco era um aliado político de Pereira da Silva, ambos governistas em 1843 sob o gabinete regressista; entretanto, eles discordavam quanto ao modo de aprovar o projeto do Código. A tática do paulista era reconhecer a relevância da opinião dos comerciantes e, ao mesmo tempo, afirmar o papel dos legisladores brasileiros. O clamor pela aprovação de um código expresso nas petições, segundo Pacheco, não podia desviar o parlamento de sua função principal: era competência exclusiva dos representantes da nação garantir que as leis aprovadas fossem as mais perfeitas possíveis.

Mas dizem os nobres deputados: - As comissões, que se compõem sem dúvida de membros muito ilustrados, já ponderaram muito na matéria. - Não duvido; mas respondo que o poder competente, que o corpo legislativo ainda não o examinou, ainda não leu sequer a matéria. E o corpo legislativo tem direito de examiná-la, deve-o mesmo fazer, porque, quando passar o Código menos pensadamente, o corpo do comércio não há de se queixar das

${ }^{225}$ Ibidem. p. 943.
${ }^{226}$ Ibidem. p. 944. 
comissões, e sim do corpo legislativo, porque a este competia sem dúvida prestar atenção a um assunto de tanta gravidade. ${ }^{227}$

Eleitos pelos cidadãos brasileiros, os deputados se constituíam em seus representantes, encarregados de fazer as leis e responsáveis por dar vida aos códigos que regeriam o Império. Por mais ilustrados, por mais competentes e bem intencionados que fossem os jurisconsultos e negociantes que elaboraram e revisaram o projeto desde 1834, não possuíam a legitimidade que possuíam os parlamentares para criar a legislação nacional. Continuava Pacheco:

sei que esta opinião é impopular; que mais popular seria gritar - passe o Código já e já - mas, passando o momento do entusiasmo, há de se reconhecer sem dúvida que a opinião daqueles que querem algum tempo para o exame da matéria é a que mais convém ao país e ao comércio. Se o corpo do comércio tem reclamado, se tem usado do direito de petição ao corpo legislativo, pedindo um código, é sem dúvida porque via que deste objeto se não tratava, pois há muitos anos que se fala em um código e ele não aparecia, mas hoje não se dá mais esta razão; hoje as comissões apresentaram o Código, o maior trabalho, a maior dificuldade está vencida, e ao corpo do comércio é mais conveniente possuir um código com menos defeitos na sessão futura, do que já e já, com maiores defeitos. ${ }^{228}$

As petições, segundo o deputado paulista, haviam cumprido seu papel: haviam dado início à atividade deliberativa. Cabia, então, aos parlamentares zelar para que a lei cumprisse seu objetivo e isso só poderia ser feito com o tempo que a atividade legislativa exigia.

Enfim, Senhores, a matéria não é para se tratar com leviandade. Eu não quero dizer que o código em questão contenha esses ou outros defeitos; presumo que as comissões trabalharam do melhor modo possível para apresentar uma boa obra; mas não é impossível que defeitos existam, e cumpre ao menos que saibamos se esses defeitos existem ou não. Portanto, cumpre que não nos deixemos arrastar unicamente do clamor público, porque aqueles mesmos que hoje clamam por um código hão de ser os primeiros a clamar contra a Câmara dos Deputados se aprovar uma medida que deixe ainda em pé os mesmos males, ou que acarrete maiores. O nobre deputado [Pereira da Silva] sabe que um artigo de lei mau pode produzir muitos e multiplicados inconvenientes. ${ }^{229}$

O clamor público se transformava, assim, num argumento a favor da calma análise do projeto. Os representantes dos brasileiros deveriam, ainda mais naquele momento, cumprir o papel que lhes havia cedido os representados: se os comerciantes e todo o a nação queriam o Código, seria obrigação do legislador fazê-lo o mais perfeito possível.

${ }^{227}$ Ibidem. p. 944.

${ }^{228}$ Ibidem. pp. 944-945.

${ }^{229}$ Ibidem. p. 945. 
Frente aos argumentos de Joaquim José Pacheco, o deputado mineiro Herculano Ferreira Penna, se colocou favoravelmente à aprovação rápida do projeto do Código:

querer retardar a discussão das leis para que passem tão perfeitas que jamais seja necessária qualquer alteração é cousa que não me parece possível e nem conveniente. Para alterá-las ou revogá-las, como o exigir a experiência e utilidade pública, é que se reúne anualmente o corpo legislativo, e quando se reconhece a utilidade do todo de uma lei, como é o Código do Comércio, parece que sem escrúpulo se pode aprová-la, ainda que depois se tenha de corrigir algum pequeno defeito. (Apoiados.) $)^{230}$

A contra-argumentação de Ferreira Penna era ainda mais perspicaz do que a dos demais defensores da aprovação imediata do projeto do Código: ele não vinha negar, como o fizeram Carneiro da Cunha ou Pereira da Silva, a utilidade da atividade deliberativa; pelo contrário, ele a reconhecia. Entretanto, transformava-a em corretiva, ao invés de preventiva, como queria o paulista Pacheco. Era a aplicação prática do Código Comercial que iria ilustrar os representantes da nação para que pudessem cumprir sua função de aperfeiçoar a legislação nacional. Ganhava força a posição em prol da discussão em globo do projeto.

O posicionamento de Ferreira Penna em relação à aprovação do Código se explicava pelo interesse que os produtores mineiros possuíam quanto à regulamentação da atividade comercial na Corte. Grande parte da produção agrícola de Minas Gerais era voltada para o abastecimento da capital do Império $^{231}$ e alguns importantes líderes políticos mineiros, como Limpo de Abreu e Ottoni, vinculavam-se diretamente à Associação Comercial do Rio de Janeiro. Vantagens para a praça comercial carioca beneficiavam também os mais importantes produtores e comerciantes de Minas. Não por acaso, a câmara municipal de Sabará enviou aos representantes da nação, no início de 1843, petição favorável à aprovação do Código:

ninguém melhor que vós, Senhores, pode notar os vícios e defeitos de que abunda a legislação que regula ao foro as contestações sobre matérias de comércio, principalmente a respeito de hipotecas, que sendo estabelecidas para segurança da propriedade de cidadãos honestos e de boa fé, infelizmente, as mais das vezes servem de capa para encobrir a fraude de bancarroteiros e especuladores refratários e de má fé: muitas das decisões em assuntos comerciais são baseadas em Leis positivas; mas outras são ditadas por arestos que a necessidade e variedade dos tempos têm introduzido e, o que é pior, zombando, não poucas vezes, a chicana e a trapaça do direito e da justiça.

\footnotetext{
${ }^{230}$ Ibidem. p. 947.

${ }^{231}$ Sobre a produção para o comércio interno na província de Minas Gerais, consultar: Alcir Lenharo. As Tropas da Moderação: o abastecimento da Corte na formação política do Brasil. 1808-1842. Rio de Janeiro: Biblioteca Carioca, 1993.
} 
Nestes termos a câmara de Sabará tomou a resolução de pedir-vos, Senhores, que vos ocupeis acuradamente da confecção de um Código de Comércio metódico e luminoso que, adaptado às atuais circunstâncias, assegure o direito de propriedade e ponha termo à fraudulência que entorpece a boa ordem requisitada em matérias de tamanha transcendência. ${ }^{232}$

A adesão dos mineiros à aprovação rápida do Código Comercial mostrava que as associações comerciais tinham grande influência sobre as mais diversas regiões do Império. Nem todos os aliados das praças de comércio, entretanto, mostraram-se felizes diante da suposta unanimidade que adquiria o projeto dentro da Câmara. Os ânimos se exaltaram quando o deputado baiano José Alves da Cruz Rios trouxe ao plenário uma acusação. Iniciava ele: "pertencendo ao comércio, seria de notar que não pedisse a palavra." ${ }^{233}$ Rios compreendia ser sua missão denunciar os interesses escusos por trás das alianças estabelecidas entre defensores do projeto na esfera parlamentar:

alegro-me por ver o nobre deputado tomar tanto a peito a necessidade do Código de Comércio e censurar-nos de que desconheçamos as necessidades do país. Folgo que os nobres deputados da maioria queiram ser populares, e não temam sofrer a acusação que nos fizeram de que nos oponhamos aos impostos para angariar popularidade e triunfarmos nas eleições, e que o pobre povo nada pode, pois tudo é feito à vontade do governo, cuja amizade se ganha apoiando-o em tudo e por tudo. Mas porque querem ser populares agora? Por esta lei reclamada por pessoas muito influentes em eleições, especialmente no Rio de Janeiro. ${ }^{234}$

Rios, ele mesmo membro da Associação Comercial da Bahia e signatário de petições a favor da aprovação do Código, acusava alguns defensores do projeto de oportunismo, pois acreditava que se utilizavam da corrente de opinião favorável ao comércio para se promoverem eleitoralmente. A acusação de Rios se dirigia ao controle da máquina eleitoral que a aliança com a praça do Rio de Janeiro poderia trazer. $\mathrm{O}$ deputado baiano fizera oposição, em nome da classe mercantil de sua província, aos impostos requeridos pelo Executivo e, por isso, havia sido acusado de obrar contra o interesse público para adquirir popularidade. Sendo assim, Rios se aproveitava da oportunidade para responder aos seus acusadores. Frente à explosão de seu suposto aliado baiano, Pereira da Silva, fazendo valer sua liderança sobre os defensores do Código, buscou acalmar os ânimos e manter a discussão longe da polêmica eleitoral:

posso assegurar ao nobre deputado em meu nome, e creio que em nome dos membros que compõem a maioria desta casa, que, se votamos a favor do

\footnotetext{
232 Petição da câmara municipal de Sabará. 01 de janeiro de 1843. Centro de Documentação e Informação. Arquivo da Câmara dos Deputados. Brasília. Consultado em fevereiro de 2009.

${ }_{233}$ Anais da Câmara dos Deputados. 30 de agosto 1843. p. 948.

${ }^{234}$ Ibidem. p. 949.
} 
Código Comercial, é porque entendemos que a sociedade brasileira tem dele necessidade. (Apoiados.) As leis fazem-se para satisfação das necessidades públicas; quando o povo sofre, os representantes do país têm obrigação de acudir a seus clamores (apoiados), e se o povo todo reconhece a necessidade urgente, imediata, desta lei, é nosso dever promovê-la. Declaro também ao honrado membro que a corporação do comércio [do Rio de Janeiro] é digna de toda a consideração, que tem direito a exigir desta Câmara todas as providências que entender justas, que eu far-me-ei eco de suas vozes, sem temor nem receio de insinuações tão infundadas, como essas que lançou o nobre deputado; e que, comportando-me por este modo, julgo preencher minha missão de representante do país, de que parte muito numerosa e brilhante é o corpo do comércio. Não sustento com a força que tenho empregado até aqui a adoção do Código Comercial, porque queira fazer genuflexões a potências eleitorais; mas sim, e unicamente, porque entendo que é nossa obrigação dar ao país as medidas e providências que ele reclama como imediatamente necessárias. ${ }^{235}$

Por meio do discurso de que o sucesso do projeto de 1834 representava o interesse de todo o país, o deputado fluminense buscava acalmar o indignado deputado baiano e defender a posição das associações comerciais. Segundo Pereira da Silva, a aprovação do Código estava acima de considerações eleitoreiras; como representantes do povo brasileiro, os deputados deveriam deixar de lado as intrigas meramente políticas e obrar juntos para atender às demandas dos representados. Neste espírito, continuava:

deixe a Câmara essas discussões de política e de partidos com que não lucra o país; corra a satisfazer as verdadeiras necessidades do país; aproveite seu tempo em discussão de objetos de interesse público, que seu prestígio se aumentará; que a confiança do povo crescerá para com seus mandatários, e os representantes do país serão dignos de seus encômios, porque souberam compreender suas verdadeiras necessidades, souberam acudir a elas, e em vez de empregar o tempo em discussões sem interesse, pelo contrário, ocuparam-se de providências tendentes a remover os males públicos. ${ }^{236}$

As discussões sobre os interesses escusos que estariam por trás da defesa do projeto, segundo Pereira da Silva, não levariam os representantes da nação a lugar algum. O interesse de todo o país era muito maior do que os egoísmos de cada posição e a aprovação do Código Comercial deveria se dar à revelia daquelas acusações infundadas. Pacificando seu indignado colega baiano, o deputado fluminense se aproveitava para colocar a demanda dos negociantes de grosso trato - grupo do qual Rios fazia parte - acima das divergências políticas que existiam na Câmara em 1843.

Apesar da posição de Pereira da Silva ter prevalecido entre os defensores do projeto e da desavença ter sido abafada, a explicitação do conflito deu espaço para

\footnotetext{
${ }^{235}$ Ibidem. p. 950.

${ }^{236}$ Ibidem. p. 951.
} 
aqueles que defendiam a postergação da discussão. Sabino, aproveitando-se da acusação trazida por Rios, defendeu seu ponto de visto mais uma vez:

quais foram as comissões encarregadas da organização do projeto? Entraram alguns negociantes, mas negociantes desta Corte. Trabalhos desta ordem devem primeiro oferecer-se à consideração e reflexão pública. Imprima-se o projeto, seja examinado pelos negociantes e jurisconsultos, admita-se a discussão; depois de se conhecer que não aparecem contra ele objeções razoáveis, que não se lhe notam defeitos e inconvenientes notáveis, então poderemos adotá-lo sem correr o risco da precipitação; mas hoje não é possível. Bem se vê pois que não estou em oposição ao voto do país; admito a necessidade do Código Comercial, mas creio que o país ou o povo ainda não pediu que adotássemos sem discussão ou precipitadamente qualquer projeto que se apresentasse à nossa consideração. O que o país reclama é a adoção de medidas justas e razoáveis. ${ }^{237}$

Como se vê, o deputado pernambucano não negava, de forma alguma, a importância da discussão pública para a definição do interesse geral. Sabino negava, sim, a coincidência imediata entre o trabalho dos idealizadores do projeto e a vontade da nação. Tirando proveito das acusações de Rios quanto à ligação dos defensores do Código com as potências eleitorais do Rio de Janeiro, Sabino argumentava que a aprovação do projeto idealizado em 1834 era uma demanda restrita aos negociantes da Corte. Para desespero de Pereira da Silva e de outros aliados das associações comerciais, o trabalho conjunto dos peticionários nos primeiros anos da década perdia força naquele momento.

Ao fim da discussão de 1843, o parecer da comissão especial do Código Comercial foi aprovado: os deputados do Império fariam somente uma discussão em globo do projeto. Contudo, o pedido de Sabino foi atendido: como somente no dia 18 de setembro a discussão teria início, o tempo necessário para os discursos previstos no regulamento seria curto demais; o baiano Ferraz propôs o adiamento da discussão para a sessão seguinte e não teve dificuldades em ver esta medida aprovada. Não se dando por vencido, Pereira da Silva ainda trouxe à Câmara uma proposta no final daquele ano:

como é o uso nos parlamentos europeus ouvirem-se comissões externas sobre matérias desta importância, o orador deseja que a Câmara dos Srs. deputados adote este uso e se aproveite das luzes das pessoas que não pertencem ao corpo legislativo. (...) Na praça do Rio de Janeiro há negociantes nacionais e estrangeiros ilustrados, a quem se devera ouvir sobre o projeto do Código. (...)

[Lendo seu requerimento]: que por intermédio do governo, se remeta à comissão da praça de comércio do Rio de Janeiro um exemplar do Código Comercial, afim de que, durante o intervalo que decorrer até o $1^{\circ}$ de maio próximo futuro, labore e faça subir a esta Câmara as observações que sobre

${ }^{237}$ Ibidem. p. 952. 
tal projeto julgar conveniente, podendo assim a Câmara mais ilustrada discutir a matéria e adotar o projeto com aquelas modificações que entender necessárias. ${ }^{238}$

A proposta do deputado fluminense foi rejeitada. Seus pares já haviam cedido o suficiente à pressão dos comerciantes; permitir que eles abertamente invadissem o debate parlamentar seria incorrer em exagero; afinal, as petições já haviam cumprido sua missão e o projeto idealizado em 1834 já seria analisado a partir de uma discussão global.

Devido à dissolução da Câmara em 24 de maio de 1844 e a saída do poder dos regressistas, o debate sobre o Código Comercial somente se restabeleceu em 1845 quando se inaugurou a situação liberal. Naquele ano, os defensores do projeto receberam uma valiosa ajuda de um grupo que, com autoridade, podia discutir os assuntos jurídicos no Império. O Instituto dos Advogados Brasileiros enviou uma petição à Câmara dos deputados na qual explicitamente defendia a posição dos comerciantes do Rio de Janeiro, Pernambuco e Bahia. O Instituto estrategicamente dirigiu sua argumentação para os benefícios mais gerais que o país obteria com a regulamentação de uma jurisprudência específica para o comércio:

ninguém hoje desconhece quanto o Comércio, criador da civilização moderna, influi na felicidade pública e nos destinos das Nações; sem ele não há Finanças nem possibilidade de as criar; sem ele definha-se a Agricultura e as Artes morrem, estancada a circulação: mas o Comércio tem por base a boa fé e confiança na palavra dada; e a boa fé e o crédito necessitam do apoio da Legislação apropriada, sem o que sucumbem sempre à malícia dos homens. ${ }^{239}$

A voz de um grupo teoricamente neutro e, sobretudo, especializado em assuntos jurídicos vinha fortalecer o pedido dos principais comerciantes do Império. À elite de negociantes se juntava a elite dos juristas para demonstrar o quanto a regulamentação do comércio seria benéfica para o país. Caberia, então, aos representantes da nação aprovar o projeto que apontava o caminho que seria o mais proveitoso para a riqueza e a civilização do país.

Em sintonia com as petições que se acumulavam em seu arquivo, a comissão parlamentar encarregada de examinar o Código Comercial, no dia 28 de junho de 1845 , entregou mais um parecer à Câmara dos Deputados:

\footnotetext{
${ }^{238}$ Anais da Câmara dos Deputados. 16 de setembro de 1843. p. 168.

${ }^{239}$ Petição do Instituto dos Advogados Brasileiros. 17 de março de 1845. Centro de Documentação e Informação. Arquivo da Câmara dos Deputados. Brasília. Consultado em fevereiro de 2009.
} 
cumpre aqui dizer que o projeto atual comparado com o primeiro projeto redigido em 1834 está muito melhorado com os trabalhos da comissão mista de 1835 , da comissão da praça de comércio, de alguns jurisconsultos e comerciantes que foram consultados e que de boa vontade concorreram para esta obra importante e ultimamente com a revisão da comissão mista de 1843; e conquanto pense a comissão que de alguma perfeição é ainda suscetível o novo projeto, julga que pode ser adotado sem grave inconveniente na sua execução, aguardando da prática de suas disposições os melhoramentos que a experiência tornar indispensáveis; porquanto cada dia se faz mais imperiosa a necessidade de dar ao país um sistema de legislação comercial, para evitar a decadência e ruína do nosso comércio, que luta com a incerteza das regras que regem as questões mercantis, decididas até o presente pelo arbítrio dos julgadores e mediante processos impróprios e ineficazes. $^{240}$

Os membros da comissão eram os deputados liberais Joaquim Antão Fernandes Leão e Paulo Barbosa da Silva, ambos de Minas Gerais, e Saturnino de Sousa e Oliveira Coutinho, do Rio de Janeiro: mais uma vez a união entre fluminenses e mineiros se estabelecia em defesa da regulamentação da atividade comercial no Império. Assim como ocorrera em 1843, quando a maioria da Câmara era composta por regressistas, em 1845 também os liberais adotaram os argumentos dos aliados do comércio, visto que a necessidade da pronta aprovação do projeto foi justificada pelo trabalho das comissões, dos jurisconsultos e dos comerciantes. A exemplo do que acontecera dois anos antes, a comissão defendeu a dispensa da discussão regulamentar do projeto.

Os aliados do comércio, ávidos pela aprovação do Código, foram capazes de aprovar o parecer da comissão em 1845. O debate em globo prometido foi esvaziado já que a maioria da legislatura estava de acordo com a premente necessidade da aprovação: as praças comerciais, mesmo sem a presença de Pereira da Silva na Câmara, haviam finalmente criado o consenso que buscavam estabelecer desde a década de 1830. Frente à pressão que se exercia pela aprovação integral e imediata do Código Comercial, José Ferreira Souto, deputado conservador pela Bahia, expressou seu descontentamento:

ora, como se há de instituir um exame, estabelecer uma discussão nestas circunstâncias e votar-se por um objeto que se não conhece? Dir-se-á que a ilustre comissão especial deve inspirar-nos toda a confiança, e portanto devemos aprovar o projeto, que ela acha vantajoso. Eu conheço que este argumento é valioso; mas a confiança que eu presto à nobre comissão, e que ela merece, não vai ao ponto de prescindir deste exame, e votar sem maior conhecimento. Este açodamento, esta precipitação em aprovarmos assim matéria tão importante e tão difícil, não me agrada; porque a experiência do

${ }^{240}$ Anais da Câmara dos Deputados. 28 de junho de 1845. p. 681. 
passado entre nós deve fazer desconfiar destes entusiasmos por certas medidas, por certas leis. ${ }^{241}$

Assim como haviam feito Ferraz, Sabino e Pacheco em 1843, Souto dizia temer as conseqüências de se aprovar um código tão importante para o país sem discutir detidamente o seu significado. O fato de existir clamor popular em prol da aprovação do projeto idealizado em 1834 não justificava, de acordo com o deputado baiano, a dispensa do debate parlamentar: os representantes da nação tinham de cumprir o seu dever e deliberar racionalmente sobre o Código Comercial. Em resposta a Souto e a alguns outros que começavam a questionar algumas prescrições do projeto, em especial a formação dos Tribunais de Comércio, outro conservador baiano, João José de Oliveira Junqueira, se pronunciou:

estou persuadido de que é impossível haver vantagem para o comércio uma vez que seus negócios não sejam decididos com prontidão. Por isso entendo que não adiantamos nada se não adotarmos essa organização de tribunais como está, suposto que para mim eu acharia melhor outra organização; mas não devo querer antepor os meus fracos conhecimentos aos dos compiladores do Código; devo mesmo duvidar de mim. Pois tantos homens esclarecidos, conhecedores da matéria, refletiram por muito tempo e acharam que esta é a organização que mais convém ao país, e hei eu de dizer que não é esta a melhor? Então eu direi que se adote esta organização. ${ }^{242}$

O deputado colocava em cheque a capacidade dos legisladores tratarem de assuntos técnicos como a criação dos Tribunais de Comércio; este posicionamento era coerente com a idéia, expressa no projeto de 1834 e defendida tanto pelas praças comerciais quanto pelos seus aliados no parlamento, de que os grandes negociantes eram os mais aptos a decidirem sobre as questões mercantis no Império. Frente à sabedoria dos compiladores e à expressão da opinião pública, cabia aos representantes da nação apenas referendar o Código. Souto e Junqueira eram ambos baianos e membros da oposição em 1845; no entanto, o último era signatário de uma petição de "negociantes e moradores da cidade da Bahia". ${ }^{243}$ Aliado à praça de Salvador, Junqueira adotava uma posição mais pragmática do que a de seu colega e comprovinciano, José Alves da Cruz Rios, em 1843: obrava pela aprovação do Código sem entrar em discussões acerca dos interesses políticos ligados à praça do Rio de Janeiro. Resolvidas as intrigas entre os aliados das associações comerciais, a aprovação do projeto se

\footnotetext{
${ }^{241}$ Anais da Câmara dos Deputados. 02 de julho de 1845. p. 23.

${ }^{242}$ Ibidem. p. 27.

243 Petição dos negociantes e moradores da cidade da Bahia. 05 de julho de 1841. Centro de Documentação e Informação. Arquivo da Câmara dos Deputados. Brasília. Consultado em fevereiro de 2009.
} 
tornava viável no debate parlamentar de 1845. Prevalecia a idéia, tão defendida por Pereira da Silva, de que o Código dizia respeito à civilização do Império e não a interesses escusos.

A voz do pernambucano Joaquim Nunes Machado, no dia 03 de julho de 1845, foi a última que se levantou na discussão. Ele questionava a parte mais importante do projeto:

eu temo, e temo muito, que nós em vez de atalharmos, vamos rodear; eu temo muito que a Câmara dos Srs. Deputados na melhor intenção de dotar o país com uma boa lei, tenha de se ver iludida em sua expectativa. Eu pedirei à casa que reflita que mesmo no Rio de Janeiro, onde 100 ou 200:000\$ não constituem uma fortuna, dois, três ou quatro negociantes decidem do comércio. E se assim é a respeito do Rio de Janeiro, o que não sucederá a respeito de outras províncias? Quererá a Câmara, votando a lei sem muita meditação, criar um monopólio a favor de dois, três ou quatro indivíduos? Quererá que só dois, três ou quatro indivíduos tenham a faculdade de comerciar, de cumprir os seus contratos da maneira que lhes aprouver, enquanto que outros bem honrados serão postos à margem e perseguidos?.... ${ }^{244}$

Levantava-se uma denúncia contra as intenções daqueles que projetaram o Código: a formação dos Tribunais de Comércio estabeleceria um verdadeiro privilégio nas mãos dos poucos comerciantes que, com mais riqueza e poder do que os demais, seriam eleitos seus deputados. Nunes Machado, assim como Sabino, era um dos fundadores do partido praieiro de Pernambuco; partido este que, na cidade do Recife principalmente, se unia aos pequenos e médios comerciantes cujo antilusitanismo estava ligado ao seu domínio sobre as principais casas comerciais. ${ }^{245} \mathrm{O}$ que o deputado pernambucano não levara em consideração ao elaborar sua acusação, no entanto, era que a maioria dos representantes da nação estava satisfeita com o fato de que a aprovação do projeto de 1834 traria grandes vantagens para a elite comerciante. Não havia, para os aliados das associações comerciais, qualquer contradição entre a vontade geral e a concessão aos negociantes de grosso trato; pelo contrário, o fortalecimento das praças do Rio, Recife e Salvador era tomado pela maioria dos deputados como um meio de engrandecer o Brasil perante as demais nações mercantis. Sendo assim, logo após a colocação do líder praieiro, o projeto do Código Comercial foi globalmente aprovado pela Câmara. O intervalo para reflexão obtido pelos críticos da proposta no ano de 1843 acabou por beneficiar os defensores do projeto que, em 1845, obtiveram a maioria necessária para ver sua demanda atendida.

\footnotetext{
${ }^{244}$ Anais da Câmara dos Deputados. 03 de julho de 1845. p. 35.

245 Marcus Joaquim M. de Carvalho e Bruno Augusto D. Câmara. “A Insurreição Praieira”. Almanack Brasiliense (IEB/USP). Número 8, novembro de 2008. p. 30. Disponível no endereço eletrônico: http://www.almanack.usp.br/PDFS/8/08 Forum 01.pdf. Acessado em 07 de fevereiro de 2010.
} 
Durante os anos de 1846 e 1847, o Senado chegou a discutir alguns artigos do Código. Senadores como Silva Maia, Carneiro Leão, Vergueiro, Clemente Pereira, Araújo Lima e Vasconcelos chegaram a sugerir emendas, contudo o projeto foi aprovado também na câmara vitalícia sem significativas alterações. Devido à turbulência em fins de 1848 na província de Pernambuco causada pelos praieiros, em 1849 a Câmara foi dissolvida. Assim, somente em 25 de julho de 1850, quando Eusébio de Queiroz se tornara presidente da comissão especial do Código, foi que o projeto originado em 1834 ganhou vida oficial. Todo trabalho, então, já estava feito: o projeto que começou a ser discutido sob uma Câmara de absoluta maioria regressista em 1843 e foi aprovado por uma maioria liberal em 1845, era por fim referendado por uma legislatura conservadora.

O debate parlamentar acerca do Código Comercial dividiu a deputação de um modo que não pode ser explicado pelas filiações partidárias e nem pelas origens provinciais: membros do mesmo partido e deputados da mesma província divergiram quanto à aprovação do projeto. $\mathrm{O}$ interesse de um grupo econômico - e não questões partidárias ou regionais - determinou os posicionamentos na Câmara enquanto o Código Comercial esteve em pauta. Conforme evidenciavam as declarações de Pereira da Silva ou a assinatura de Junqueira em petições de negociantes da Bahia, as lideranças parlamentares favoráveis à aprovação do projeto de 1834 estavam diretamente ligadas às associações comerciais e, conseqüentemente, aos negociantes de grosso trato de Salvador, Recife e Rio de Janeiro - esta última, cidade onde também exerciam suas atividades comerciais os importantes produtores mineiros. "Most leading groups" escreve Eugene Ridings sobre as principais associações comerciais do Império - "had several deputies (...) who spoke for them in legislative and administrative circles." 246 Baseados sobre o discurso contido nas petições, os aliados do comércio na Câmara fossem eles de um partido ou outro, fossem eles de qualquer província do Império combateram tudo o que fosse estranho ao benefício das praças comerciais. A intervenção pacificadora de Pereira da Silva na questão dos interesses eleitoreiros levantada por Rios, em 1843, foi um claro exemplo dessa estratégia de ação política dos defensores do comércio.

Ainda de acordo com Ridings, "association boards held the wealthiest and most influential of each business community. The Brazilians among them included most of

\footnotetext{
${ }^{246}$ Eugene Ridings. Op. Cit. p. 69.
} 
the nation's famous businessmen": ${ }^{247}$ conclui-se por aí que, ao cederem às associações comerciais, de fato, os representantes da nação beneficiavam um setor específico da elite econômica brasileira, o qual, doravante, teria controle sobre os Tribunais de Comércio. Isto não significava, todavia, que a maioria dos legisladores agisse como delegada de um interesse particular: o triunfo dos defensores do projeto se deveu à sua capacidade de, dentro das regras estabelecidas pelo sistema político do Império, transformar o interesse concreto dos principais negociantes de Salvador, Recife e Rio de Janeiro num assunto que dizia respeito a todo o Brasil. A demanda das associações comerciais foi tomada como uma demanda legítima pela maioria dos representantes da nação pois não se mostrou como um favor ou uma concessão a um grupo específico; durante a década de 1840, a influência das associações comerciais fez prevalecer na Câmara o ideal de que o fortalecimento das praças comerciais contribuiria para o enriquecimento e a civilização do país como um todo. Acreditavam os deputados, ao aprovaram o Código Comercial, que o benefício direto de alguns não traria prejuízo para o resto da nação; pelo contrário, a delegação de poder aos negociantes de grosso trato no que se referia às contendas mercantis foi entendida pelos parlamentares como uma via de se racionalizar as relações econômicas no Brasil e, conseqüentemente, fazer progredir toda a sociedade brasileira.

Ainda que tenham cedido aos apelos das associações comerciais, os representantes da nação não abandonaram sua função: o projeto foi enviado para comissões parlamentares e foi discutido em plenário; os deputados descontentes - a exemplo do que fizeram Sabino, Pacheco, Ferraz, Souto e Nunes Machado - tiveram oportunidade de tecer suas críticas e obtiveram o tempo exigido para reflexão. Foi a partir da deliberação dos representantes da nação que se concluiu que o projeto idealizado em 1834 condizia com o interesse nacional: somente depois de 16 anos de muitos debates, análises, ponderações e negociações prevaleceu a idéia de que a causa das associações comerciais representava mais do que a concessão de um privilégio a grupo específico. A aprovação do Código Comercial foi legitimada a partir de uma longa e complexa atividade deliberativa que terminou por comprovar para a maioria dos parlamentares que os princípios contidos no projeto idealizado pelo Visconde de Cairu e por outras autoridades em questões mercantis traria benefícios para o Império de um modo geral.

\footnotetext{
${ }^{247}$ Idem. Ibidem. p. 37.
} 
Sem poder criar a legislação nacional por conta própria - atividade que, sob o regime representativo, competia exclusivamente aos representantes eleitos da nação -, os negociantes de grosso trato decidiram influenciar os parlamentares em prol da aprovação de um Código Comercial idealizado por alguns dos seus. As insistentes associações da Corte, do Recife e de Salvador, ao unirem seus esforços (e contando com o relevante apoio de uma câmara municipal mineira e do Instituto dos Advogados), foram bem-sucedidas em sua empreitada: conseguiram, por meio das petições e da atividade parlamentar de seus aliados, legitimar sua causa demonstrando que o Código promoveria a felicidade de toda a sociedade brasileira. Inseridas na lógica do regime, as associações comerciais souberam fazer uso dos instrumentos políticos que possuíam e, dentro da legalidade, alcançaram seu objetivo. 


\section{CAPÍTULO 5. A ELITE POLÍTICA LUZIA E A LUTA CONTRA AS "LEIS REACIONÁRIAS"}

A abdicação de D. Pedro I foi seguida por um considerável rearranjo institucional no Brasil. Unidas contra setores lusófilos e, supostamente, restauracionistas, lideranças políticas liberais mais ou menos moderadas elaboraram um projeto político com vistas a garantir a soberania nacional. O reformismo da primeira metade da década de 1830 - conduzido por figuras díspares como Bernardo Pereira de Vasconcelos e Diogo Antonio Feijó - enraizou o poder estatal nas províncias do Império por meio de um arranjo de tipo federativo. O Código de Processo Criminal (1832) - que reformava o judiciário fortalecendo magistrados eleitos localmente e o conselho de jurados - e o Ato Adicional (1834) - que criava as Assembléias Provinciais e extinguia o Conselho de Estado - fizeram parte de uma tentativa de se redistribuir os poderes dentro de uma nova ordem que se inaugurava. ${ }^{248}$ Os efeitos de tal obra foram duradouros, contudo alguns ajustes foram feitos para que as reformas liberais do período pós-Abdicação se assentassem sobre uma base segura. Uma política de reação foi instaurada em seguida da derrubada do regente Feijó, incapaz de conter o secessionismo que ameaçava a unidade nacional. Entre os anos de 1838 e 1841, estadistas como Honório Hermeto Carneiro Leão, Joaquim José Rodrigues Torres, Paulino José Soares de Sousa e o próprio Vasconcelos conduziram uma reformulação das medidas aprovadas pela Regência que ficou conhecida, a partir da denominação dada pelos seus adversários, como política do Regresso ou "leis reacionárias". ${ }^{249}$ Os regressistas foram bem-sucedidos na medida em que interpretaram o Ato Adicional, reformaram o Código de Processo, reinstauraram o Conselho de Estado e impuseram outras medidas que definiam melhor a atuação do centro do Império sobre suas partes. No entanto, também esta revisão legislativa traria perigosas conseqüências para o sistema político brasileiro.

Pouco antes da eclosão do levante de 1842, a Assembléia Provincial de São Paulo enviou aos representantes da nação brasileira uma petição em tom indignado que atacava política do ministério regressista que tomara posse em 23 de março de 1841. A petição, datada de 28 de janeiro de 1842, apelava aos deputados eleitos pelo povo brasileiro para que defendessem o jovem imperador e todo o Império contra o que

\footnotetext{
${ }^{248}$ Sobre o tema do pacto federativo no Império, consultar: Miriam Dolhnikoff. O Pacto Imperial. Op. Cit.

${ }^{249}$ Sobre a ascensão política dos regressistas, consultar: Jeffrey Needell. Op. Cit. pp. 51-80.
} 
consideravam uma usurpação. O ministério, segundo os peticionários, não respeitava sequer os preceitos da Constituição, substituindo-os pelo desmando e pela truculência.

Ele ignora que o nome de Lei não pode caber a atos de pura força brutal e dissoluto arbítrio. Estes atos, Senhores, não são leis por pecarem na forma e na matéria. Pecam na matéria por lhes faltar o que constitui a idéia de Lei. No Sistema Constitucional a Lei é a expressão da vontade Nacional declarada por seus legítimos representantes e selada com o cunho do Imperante; mas a vontade Nacional não é e nem pode ser senão o resultado da opinião reinante: ora, a opinião reinante reprova a prescrição desses atos, até por serem decretados por intérpretes infiéis, rejeitados pela maior parte pelo Povo Soberano. Pecam na forma pelo modo porque foram introduzidos: eles alteram claramente a Constituição, o que é indisputável; e, sendo assim, era de mister que não fossem tais alterações criaturas de uma legislatura ordinária, como foram. Demais: não há lei sem imparcial e conscienciosa discussão, sobretudo quando se trata do que é puramente constitucional; a fortaleza da Constituição se não deve levar de assalto, preciso é rodeá-la de regular assédio e apoderar-se pouco a pouco dos postos que a defendem para que, convencida da necessidade, capitule a guarnição salvando sempre o que é essencial. Não foi assim que procedeu a corrompida ou iludida maioria da Assembléia [Geral] passada; cega e tumultuária para levar avante os nefários projetos do governo, calcou todas as regras não só da justiça, como até a da mais comum decência.

A principal queixa da elite política paulista se dava em relação à Reforma do Código de Processo Criminal e à reinstauração do Conselho de Estado, ambas medidas implementadas pelo gabinete de 23 de março no ano de 1841. Os paulistas não admitiam perder as conquistas políticas do tempo da Regência, conquistas que, acreditavam eles, eram o triunfo da ordem liberal no Império brasileiro. A odiosa Oligarquia (denominação dada pela elite política paulista aos regressistas) se opunha à vontade nacional que sempre ansiara, desde os dias da luta contra o absolutismo português, por um regime baseado na liberdade. Diziam ainda os deputados provinciais paulistas que os princípios da política deixavam claro que o poder devia ser o apanágio da inteligência e da riqueza social: o povo brasileiro, que aumentava dia-a-dia sua ilustração e prosperidade, exigia cada vez maior liberdade e ingerência nos negócios públicos. Assim, acreditavam ser um verdadeiro "contra-senso que se tire ao ilustrado o que se concedeu ao ignorante, que se negue ao rico o que se tinha outorgado ao pobre. Isto porém é o que fazem as cerebrinas Reformas do Código [de Processo Criminal]."

A Constituição concedera aos brasileiros uma vida de liberdades e justiça, "a tirania e a cegueira", contudo, "nos pretendem reduzir a um regime ainda inferior ao dos tempos coloniais, fazendo ressurgir debaixo de novos nomes os velhos capitães-mores, piorados pela flutuação da amovibilidade e com o inaudito crescimento do Poder 
Judiciário": eis a interpretação da Assembléia paulista acerca da lei que reformara o Código de Processo Criminal em 03 de dezembro de 1841. "Igual violência e ainda maior escárnio" - continuava a petição - "é a monstruosa Lei do Conselho de Estado." Forjado com a finalidade de "manietar a Coroa para não poder descartar-se de um ministério imbecil e atroz," o Conselho era considerado uma aberração pelo liberalismo paulista da década de 1840. Imaginar que o país aceitaria tais medidas seria contar "muito com nossa ignorância em um tempo em que o regime liberal continuado tem aclarado e abrilhantado à luz que com ele despontará." Não obstante o esforço dos inimigos da liberdade, o povo brasileiro teria "a precisa penetração para descobrir os abusos de que sofre" e tomaria as medidas que fossem necessárias contra o partido compenetrado "em introduzir uma nova falange de abusos, em alargar o círculo já de sobejo amplo da corrupção.” No Brasil não havia, segundo os peticionários, espaço para um governo "mais extravagante que o delírio do frenético, mais desprezível que a estupidez do saduceu." Seguia-se, então, uma manifesta ameaça de rebelião:

e qual será o êxito da luta que se vai assim criar? A Assembléia Provincial de São Paulo estremece ao dizê-lo; mas crê que ele não será duvidoso, nem longo e conflituoso; a vitória será sim deplorável, como é toda vitória conseguida contra a ordem, e ainda mesmo contra o crime; mas a responsabilidade pesará sobre aqueles cujas injustiças, atrocidades e desatinos provocaram o que pode vir a ser uma sanguinolenta e injustificável vingança.

Senhores, as convulsões políticas, como funestos cometas, trazem em sua calda os estragos, as misérias, os derramamentos de sangue mesmo inocente e o abalo dos governos estabelecidos e talvez sua inteira ruína. Como não deprecará pois a Assembléia Provincial de São Paulo o exercício do poder tutelar do monarca para arredar de si tão medonho porvir? Já se nos antolha lobrigar na lava revolucionária os talismãs quebrados da hierarquia e da autoridade; e só da piedade de S. M. I. e C. ${ }^{250}$ esperamos o sossego de nossa inquietação.

O levante armado contra o domínio da Oligarquia já fazia parte dos cálculos da elite paulista em janeiro de 1842: a petição à Câmara dos Deputados servia como um último aviso. A defesa das instituições nacionais custaria o sangue da província de São Paulo; desesperados, os paulistas não teriam escolha a não ser mergulhar numa guerra fratricida.

Senhores, não creia a Assembléia Geral que a Assembléia Provincial inventa fantásticos perigos, sonha males não existentes. Não, Senhores, a província inteira se levanta como um só homem contra as denominadas leis: algumas das câmaras [municipais] já se têm energicamente pronunciado contra elas; receia-se que as restantes sigam o exemplo e que as acompanhem os Eleitores e mais

\footnotetext{
${ }^{250}$ Sua Majestade Imperial e Constitucional.
} 
autoridades. Talvez os desleais Conselheiros, que abusam da bondade de S. M. I. e C., lhe gritem aos ouvidos que a firmeza é uma grande virtude no manejo dos negócios públicos, que as conspirações e insurreições são melhor pelo vigor e decisão e que recuar ante elas é fazê-las formidáveis, mas, Senhores, a firmeza tem sua esfera própria, além é vício; pequenos motins e assoadas comprimem-se com o vigor, mas repugnâncias fundadas em princípios que constituem a vida dos povos só o compromisso, e compromisso gracioso e a tempo, pode curar. Um governo assisado não trata os arraigados descontentamentos de uma província inteira como trataria a explosão de um motim comum; um governo sábio não confunde a inflamação que invade até o âmago do sistema da Nação com a ligeira irritação local.

A ameaça não podia ser mais clara: toda a província começava a se incomodar contra a política dos regressistas. Uma verdadeira guerra se instalaria caso uma medida radical não fosse adotada: "Senhores, nenhum benefício que S. M. I. e C. possa fazer à nossa Pátria poderá penhorar tanto a gratidão do Povo como a demissão de tão inepto quanto atroz ministério." Acordo algum poderia ser feito com homens tão avessos às liberdades pátrias, somente sua demissão acalmaria os ânimos dos injuriados peticionários. "Nunca abutres tão esfaimados prearam as entranhas do Brasil;" continuavam os deputados provinciais paulistas - "nunca tão imundas harpias enxovalharam o solo puro do Império de Santa Cruz." Sob o domínio do 23 de março a justiça fora jogada na lama, a imoralidade atingira seu apogeu, a sórdida doutrina do interesse mesquinho substituíra a dos princípios; o regime do Estado fora entregue ao capricho, a razão conspurcada, a honra e a capacidade exiladas de todos os empregos para dar lugar à dócil e venal clientela; aos cidadãos haviam sido arrancadas "as mais sagradas garantias, qual o direito de petição"; a pacificação do Rio Grande do Sul, vital para o Império, retardada e estorvada, se não de todo impossibilitada. Por outro lado, assalariava-se a corrupção e premiava-se o vício e o crime nas pessoas de traidores e assassinos; a crueldade marchava de cabeça levantada, "rodeada de rios de sangue, de gemidos e ais do sofrimento e desesperação" superando até mesmo o que "a barbaridade turca, aguilhoada pelo fanatismo religioso, perpetrou de horrores na Grécia insurgida" e "o frio despotismo do Autocrata do Norte despejou de males sobre a malfadada Polônia." Eis a obra da Oligarquia, eis o resultado "da medonha vida pública do ministério que desonra o Brasil e atraiçoa a S. M. I. e C., ilaqueando a sua Boa Fé e fazendo-o aparecer não como Pai, que é, mas como Tirano, que não é, dos seus Povos." Em suma, acreditava a Assembléia Legislativa de São Paulo que o domínio político dos regressistas retirava o Brasil da esfera da civilização, colocando em risco a existência da 
monarquia constitucional. Se nada fosse feito, somente uma guerra patriótica poderia salvar a liberdade no Império brasileiro. ${ }^{251}$

O discurso da Assembléia paulista sobre o descontentamento geral de sua província não era um blefe: demonstrando a força da resistência contra as "leis reacionárias" por toda a província de São Paulo, chegaram ao parlamento outras petições naquele mesmo ano de 1842. Duas delas vinham anexas ao documento formulado pela Assembléia. As câmaras municipais de Cunha e de Ubatuba haviam peticionado aos seus representantes provinciais para que estes dirigissem à legislatura nacional as queixas de seus munícipes. Diziam os vereadores de Cunha que uma facção infensa ao Brasil estava em vias de desviar Sua Majestade do caminho que o povo brasileiro o colocara com o Movimento da Maioridade. Sedenta de mando, a odiosa facção regressista procurava perpetuar-se no poder por todos os meios, mesmo que, para isso, colocasse em risco a legitimidade da Coroa e causasse "inumeráveis sofrimentos da Nação, que pretende escravizar, privada de todos os direitos e garantias constitucionais e extinguir nela o governo monárquico constitucional representativo, submetendo-o no todo ao governo oligárquico." Rogavam os cunhenses para que a Assembléia paulista fizesse uso de todas suas forças para fazer chegar ao trono e ao parlamento nacional "os justos clamores que de todos os ângulos do Império se levantam contra uma ordem de coisas, que a não ser energicamente obstada, trarão a dissolução e inevitável ruína do Império de Santa Cruz." O Brasil, concluíam os peticionários, só conseguiria atingir os altos patamares que a civilização lhe prometia caso uma mão benéfica o arrancasse "das garras dessa facção que a domina," inutilizando "essas leis tirânicas e atos de barbaridade com que a mesma facção nos tem transmitido e procura reduzir a uma completa escravidão.",252

A outra petição anexa à da Assembléia Legislativa declarava que a câmara municipal e o povo da vila de Ubatuba, "compartilhando a opinião de todos os paulistas que verdadeiramente sabem prezar este nome," pediam aos representantes provinciais que, tendo em vista "o calamitoso estado político de nossa pátria," buscassem descobrir os meios mais eficazes, "que dentro da órbita da Lei, possam obstar a realização dos planos tresloucados com que uma facção terrível, ávida de mando e de riquezas, ousou já cercear nossas garantias constitucionais para assim melhor conseguir seus iníquos

${ }^{251}$ Petição da Assembléia Legislativa de São Paulo. 28 de janeiro de 1842. Centro de Documentação e Informação. Arquivo da Câmara dos Deputados. Brasília. Consultado em fevereiro de 2009.

${ }^{252}$ Petição da câmara municipal de Cunha. 17 de janeiro de 1842. Centro de Documentação e Informação. Arquivo da Câmara dos Deputados. Brasília. Consultado em fevereiro de 2009. 
fins." Rogavam à Assembléia Provincial para que representasse "aos Supremos Poderes do Estado pedindo a revogação dos artigos anticonstitucionais que se notam na lei da Reforma do Código de Processo e na lei que criou o Conselho de Estado."253

Ainda mais arrojada do que seus aliados de Cunha e Ubatuba, a câmara municipal de Bragança dirigiu-se, no mesmo mês de janeiro de 1842, diretamente à legislatura geral. O tom, mais ameno do que o da Assembléia paulista, não deixava de demonstrar descontentamento com os rumos da política nacional sob domínio do gabinete regressista de 23 de março.

A câmara municipal da vila de Bragança, que nutre, como todos os bons brasileiros, sentimentos patrióticos, adesão à liberdade, integridade do Império e segurança pública, confiada na ilustração de seus atuais Representantes, julga que a essa Assembléia [Geral] não faltam meios de salvar a província da horrorosa crise que se lhe antolha. A Reforma do Código de Processo parece foi feita com o único fito de aniquilar a liberdade pública, oprimir aos cidadãos e escravizar a um povo livre: esta Lei de Reforma, Senhores, não pode por maneira alguma ser executada sem que a província inteira se ressinta das mais atrozes perseguições; sem que a liberdade individual seja calcada por um Agente da Polícia. E vós, Senhores, a quem compete velar na guarda da Constituição, das Leis e dos Sagrados Direitos dos Cidadãos; vós, que representais o povo, à vós compete empregar os meios que vos sobram para salvar a província dos grilhões que se nos preparam, tomando medidas enérgicas afim de que esta Lei atentatória do pacto fundamental não seja executada nesta província.

Esta câmara confia mais que tudo no patriotismo de seus Representantes e espera que desse centro luminoso partirão medidas que possam embaraçar a torrente de males que nos ameaçam. ${ }^{254}$

Deputados e vereadores da província de São Paulo eram claros em sua demanda: as "leis reacionárias", incompatíveis com o regime constitucional, deveriam ser combatidas em 1842 pelos representantes da nação, comprovando assim que o gabinete de 23 de março não governava com o beneplácito do povo brasileiro. Para que conseguissem seu objetivo apelavam ao direito de petição, mas não descartavam a possibilidade de uma rebelião armada caso aquela forma de manifestação pacífica da vontade nacional não fosse respeitada.

Não obstante o esforço empreendido, as petições da elite política paulista não foram sequer recebidas pelos representantes da nação. Pior, a legislatura eleita sob o Gabinete Maiorista, que assumiria em 1842, não chegou a sequer a se reunir, tendo sido

${ }^{253}$ Petição da câmara municipal de Ubatuba. 28 de janeiro de 1842. Centro de Documentação e Informação. Arquivo da Câmara dos Deputados. Brasília. Consultado em fevereiro de 2009.

${ }^{254}$ Petição da câmara municipal de Bragança. 22 de janeiro de 1842 . Centro de Documentação e Informação. Arquivo da Câmara dos Deputados. Brasília. Consultado em fevereiro de 2009. 
previamente dissolvida no dia $1^{\circ}$ de maio de 1842 sob a justificativa de que as eleições de 1840 haviam sido vergonhosamente fraudadas. ${ }^{255}$ Daquele dia em diante, o divórcio entre o poder central e a elite política de São Paulo estava firmado. Frente a uma demonstração de força da Oligarquia, os paulistas se viram sem ter mais a quem recorrer: entendiam eles que os próprios representantes eleitos da nação brasileira haviam sido esbulhados de sua posição pelos ministros do 23 de março. As petições escritas em janeiro de 1842 jamais seriam recebidas.

Mais uma petição foi enviada em 1842 pela Assembléia paulista, desta vez ao imperador, e não obteve resposta. A situação se complicou ainda mais quando, também descontente, a elite política de Minas Gerais começou um movimento próprio com propósitos semelhantes aos dos paulistas. Estava dado o cenário da rebelião: a ascensão do gabinete de 23 de março retirou do Poder Executivo lideranças que haviam levado a cabo o Movimento da Maioridade; a Reforma do Código de Processo Criminal representou para líderes paulistas e mineiros a tomada do Poder Judiciário e da polícia pelos delegados da Oligarquia; a reinstauração do Conselho de Estado foi compreendida como uma forma de se manipular o imperador (e, conseqüentemente, o Poder Moderador) pelas hostes do Regresso; a dissolução da Câmara destituiu do Poder Legislativo os representantes eleitos da nação; o silêncio desdenhoso do poder central frente às queixas dos peticionários foi interpretado como a provocação mais perversa. Organizados pelas câmaras municipais de São Paulo e Minas Gerais, grupos rebeldes se levantaram contra a falta de legitimidade que enxergavam no governo do Regresso. ${ }^{256}$

O conflito armado representou a consumação do cisma no seio da elite política brasileira que conduzira o Estado desde a Abdicação. Segundo o historiador Jeffrey Needell, "these provincial revolts of 1842, although small-scale and poorly organized militarily, were perceived with great alarm by the reactionaries and thought to be of tremendous political significance. ${ }^{, 257}$ A guerra se dava entre aqueles que, havia pouco, consolidaram juntos a ordem política do Império. Os levantes de 1842 significaram para além do sangue derramado - um claro divórcio entre grupos rivais dentro do Império brasileiro. A negociação entre projetos políticos diversos se transformara numa

\footnotetext{
${ }^{255}$ Ver capítulo 3 da presente dissertação.

256 Sobre a interpretação que os próprios liberais fizeram do movimento de 1842, consultar: Roberto Nicolas P. F. Saba. "O Libelo do Povo: um incêndio em terras saquaremas". Revista Em Tempo de Histórias (UnB). Volume 14, 2009. Disponível no endereço eletrônico:

http://vsites.unb.br/ih/novo portal/portal his/revista/arquivos/edicoes anteriores/1.2009/N2\%20O\%20Li belo\%20do\%20Povo\%20-\%20Roberto\%20Saba.pdf. Acessado em 20 de setembro de 2009.

257 Jeffrey Needell. Op. Cit. p. 102.
} 
guerra civil entre importantes elites regionais (mineira e paulista) e governo nacional (dominado pelos regressistas com base na província do Rio de Janeiro e o apoio de líderes políticos nortistas); o regime representativo brasileiro não se mostrara capaz de conter o ímpeto das facções.

Com Honório Hermeto Carneiro Leão responsável pela articulação política da repressão e com o Barão de Caxias responsável pelas operações militares, já em junho de 1842 a rebelião paulista foi abafada e em agosto do mesmo ano os mineiros se renderam no município de Santa Luzia. Após a pacificação, os rebeldes foram presos e processados. Segundo o historiador Francisco Iglésias, "eles próprios quiseram o processo, pois, exposta em público a questão, poderiam justificar-se, mostrando que não haviam feito crime, mas resistência legal. O tribunal do júri que os julgou concedeu a todos liberdade. (...) A anistia foi decretada pelo imperador em 14 de março de 1844. (...) As queixas se diluem, principalmente depois que os conservadores saem do poder, e os liberais, convocados [para assumir o Poder Executivo], não tomam providências para a reforma das leis pelas quais diziam ter-se levantado em armas. De fato, dominando de 1844 a 1848, os antigos rebeldes percebem que elas são essenciais para a defesa da ordem, cuidando de conservá-las. ${ }^{258}$ A tese mais comum na historiografia sobre a década de 1840 é que, após o levante de 1842, os luzias - como ficaram conhecidos paulistas e mineiros após a derrota no município mineiro - teriam se readequado à ordem imperial, abraçando inclusive as reformas e as instituições que os levaram à rebelião. Contudo, uma série de petições vindas de câmaras municipais de Minas Gerais e São Paulo à Câmara dos Deputados no ano de 1845 demonstram que as pretensões de 1842 tiveram continuidade, agora por uma via legítima.

Depostos os regressistas, ascendeu ao Poder Executivo em 02 de fevereiro de 1844 um gabinete politicamente moderado e pragmático, cujas figuras se opunham ao estreito partidarismo abraçado pelos regressistas; iniciava-se o período da história do Império que ficou conhecido como qüinqüênio liberal. ${ }^{259}$ No dia 24 de maio daquele mesmo ano, a Câmara que dera sustentação aos regressistas foi dissolvida e novas eleições foram convocadas, sendo eleitos muitos dos ex-rebeldes que se beneficiavam da recente anistia. Sustentáculos do levante de 1842, as câmaras municipais de Minas e São Paulo se aproveitaram da oportunidade para defenderem seu projeto político

258 Francisco Iglésias. "Minas Gerais" In: Sérgio Buarque de Holanda (org.). História Geral da Civilização Brasileira. Tomo II: O Brasil Monárquico. Volume 4: Dispersão e unidade. Rio de Janeiro: Bertrand Brasil, 2003. pp. 469-470.

${ }^{259}$ Jeffrey Needell. Op. Cit. pp. 108-109. 
esmagado pelo Regresso. O discurso das elites políticas de Minas e São Paulo se fundamentou, então, sobre três pontos: em primeiro lugar, todas elas demonstravam esperança quanto a um novo tempo que se inaugurava a partir da eleição da nova legislatura; em segundo lugar, as petições rememoravam a revolta de 1842 e a obra opressora erguida pela Oligarquia; por fim, boa parte das câmaras paulistas e mineiras propunham direta e abertamente quais mudanças políticas deveriam ser levadas a cabo pelos recém-eleitos representantes da nação.

A petição da câmara municipal da cidade mineira de Caldas sintetizava o sentimento de suas coirmãs: "grandes são por certo os males que desgraçadamente ainda pesam sobre nossa cara Pátria, mas esta câmara tem implícita fé que na vossa alta sabedoria e acrisolado patriotismo encontrará a Nação a tábua de sua salvação." ${ }^{260}$ Os vereadores da cidade paulista de Paranaguá também mostraram confiança na ação dos deputados gerais: "sim, Augustos e Digníssimos Senhores Representantes da Nação, a grande família brasileira nutre em si a mais firme esperança que do corpo legislativo aparecerão os remédios mais eficazes ao bem geral dos povos por quem representais. ${ }^{261}$ Aos representantes da nação era outorgado um poder terapêutico, sua ação deveria ser o remédio para os males que afligiam a nação. A câmara municipal de Castro, província de São Paulo, se colocou da mesma forma:

Augustos e Digníssimos Senhores, o alto conceito que o Brasil forma de vós e a bem fundada esperança de que sereis prontos a acorrer com sábias providências aos males que pesam sobre o Estado, nos faz crer que esta Augusta Câmara aplicará todos os esforços em extirpar a origem destes males, fazendo destarte com que mais se consolide a forma de governo que felizmente nos rege. ${ }^{262}$

O poder atribuído aos deputados gerais tinha um fundamento: sua eleição. Por serem os verdadeiros representantes da nação brasileira, eles teriam a capacidade de legislar em seu benefício:

a câmara municipal da cidade de Minas Novas, na província de Minas Gerais, como fiel órgão dos habitantes do seu município, vem felicitar a vós, Augustos e Digníssimos Senhores Representantes da Nação Brasileira, a vós que sois a expressão mais clara e sincera do Brasil inteiro e de quem certo depende a felicidade da Terra de Santa Cruz. Tal é, Augustos e Digníssimos Senhores, a confiança desta câmara pela vossa reunião, que desde já prevê a estabilidade de nossas

\footnotetext{
260 Petição da câmara municipal de Caldas. 07 de janeiro de 1845. Centro de Documentação e Informação. Arquivo da Câmara dos Deputados. Brasília. Consultado em fevereiro de 2009.

${ }^{261}$ Petição da câmara municipal de Paranaguá. 24 de janeiro de 1845. Centro de Documentação e Informação. Arquivo da Câmara dos Deputados. Brasília. Consultado em fevereiro de 2009.

${ }^{262}$ Petição da câmara municipal de Castro. 10 de maio de 1845. Centro de Documentação e Informação. Arquivo da Câmara dos Deputados. Brasília. Consultado em fevereiro de 2009.
} 
instituições, a segurança do Trono Constitucional e o engrandecimento de todo o Império. ${ }^{263}$

Estabilidade, segurança, engrandecimento, felicidade e paz: estas seriam, de acordo com os peticionários luzias, as conseqüências trazidas pela manifestação da livre vontade do povo brasileiro por intermédio de seus verdadeiros representantes.

Acreditavam as elites locais paulista e mineira que, ao contrário do que havia sido feito pela legislatura eleita sob os desmandos da Oligarquia, a legislatura liberal que se iniciaria em 1845 honraria sua responsabilidade de afirmar a ordem constitucional no Império. Assim, a câmara municipal de Uberaba, "cheia de júbilo, de que se acha possuída, vendo sentados nos bancos da Representação Nacional os eleitos pelos espontâneos votos da Nação," dizia esperar "o melhoramento, que o reclama o Brasil, confiada na vossa sabedoria e patriotismo; e convencida dele, conta desde já ver uma nova era de paz e de prosperidades radiar no nosso horizonte político."264 Já a câmara municipal da cidade de Sabará dizia-se cheia de prazer "por ver satisfeito o voto nacional com a escolha de cidadãos que, conhecedores das necessidades públicas, lhes aplicarão os remédios que urgentemente reclamam." ${ }^{265}$ A câmara municipal de Diamantina, seguindo pelo mesmo caminho de suas aliadas, demonstrava confiança em que dias melhores se afiguravam para os súditos da monarquia brasileira:

grandes, muito grandes são as esperanças que o País há depositado na presente legislatura! E tal é sua confiança para com a Câmara, que ele julga ser a verdadeira expressão de seus pensamentos, que quase todos os brasileiros, com a mui pequena exceção de poucos, aguardam agora prontos e acertados remédios aos males que por tantas vezes têm ameaçado o Império de Santa Cruz de ser riscado do Catálogo das Nações Civilizadas! ${ }^{266}$

Levar o país pela estrada da civilização: este era o papel atribuído aos eleitos da nação pelos peticionários de importantes cidades mineiras e paulistas. Grandes expectativas nasciam em relação às futuras ações da nova Câmara dos Deputados e as elites políticas derrotadas em 1842, fazendo uso de seu direito de petição, visavam abrir um canal para suas demandas políticas em 1845. Assim, os vereadores não poupavam elogios ao se referirem à nova legislatura.

\footnotetext{
${ }^{263}$ Petição da câmara municipal de Minas Novas. 14 de janeiro de 1845. Centro de Documentação e Informação. Arquivo da Câmara dos Deputados. Brasília. Consultado em fevereiro de 2009.

264 Petição da câmara municipal de Uberaba. 05 de maio de 1845. Centro de Documentação e Informação. Arquivo da Câmara dos Deputados. Brasília. Consultado em fevereiro de 2009.

${ }^{265}$ Petição da câmara municipal de Sabará. 11 de janeiro de 1845. Centro de Documentação e Informação. Arquivo da Câmara dos Deputados. Brasília. Consultado em fevereiro de 2009.

${ }^{266}$ Petição da câmara municipal de Diamantina. 08 de janeiro de 1845 . Centro de Documentação e Informação. Arquivo da Câmara dos Deputados. Brasília. Consultado em fevereiro de 2009.
} 
A câmara municipal da vila Franca do Imperador com o mais profundo respeito tem a honra de se elevar até a vossa presença para entregar-vos os puros e sinceros votos de felicitação que jubilosos vos enviam os munícipes francanos pelo fausto acontecimento de haverdes sido os escolhidos para representar a nação numa época em que tanto convém plantar por uma vez no Império a paz e garantir os direitos do cidadão, por que só homens ilustrados, probos e decididos respeitadores da Constituição e professos da humanidade como vós o sois, podem abrir no fértil e vasto Império de Santa Cruz uma nova idade feliz e perdurável. ${ }^{267}$

A intenção era estabelecer uma aliança com a legislatura proveniente das eleições de 1844 e, assim, retomar, por vias legítimas, o combate que em 1842 havia malogrado. A câmara municipal da vila do Bananal congratulava a reunião dos escolhidos da nação brasileira - "da qual o Brasil augura tão felizes resultados" - e se dizia esperançosa de "que leis sábias e adaptadas às suas mais urgentes necessidades serão discutidas e aprovadas para que de uma vez firmada a Constituição possa o país chegar com passo seguro àquele zenit de glória para que foi talhado pela natureza." Depois de tantos crimes contra a Constituição do Império, aos representantes da nação havia sido confiada uma "grande obra" e a câmara do Bananal "não podia deixar de patentear seu júbilo quando vê reunidos aqueles a quem as urnas eleitorais designaram para suster e afastar a tempestuosa queda que ao Brasil ameaçava." ${ }^{268}$ Por sua vez, a câmara municipal da cidade mineira de Aiuróca dizia-se convencida de que "unicamente no Santuário da legislatura provir pode a Nação a mais progressiva prosperidade e, a par desta, entre si oscularem-se a justiça e a paz"; por isso, desejava demonstrar aos representantes da nação, por meio do exercício do direito de petição, "seu reconhecimento à incansável solicitude com que na penosa tarefa que vos é confiada promovereis com patriótico empenho a felicidade do Brasil." 269

As elites políticas de São Paulo e Minas Gerais se curvavam diante daqueles que consideravam como verdadeiros representantes do povo brasileiro; o estado de espírito de seus munícipes refletia já a nova era que se abria na história pátria. Assim, os vereadores de Santa Maria de Baependi, província de Minas Gerais, asseguravam que em seu município reinava a "paz e inalterável afinco às instituições monárquicas

267 Petição da câmara municipal de Franca do Imperador. 15 de janeiro de 1845. Centro de Documentação e Informação. Arquivo da Câmara dos Deputados. Brasília. Consultado em fevereiro de 2009.

268 Petição da câmara municipal de Bananal. 01 de fevereiro de 1845. Centro de Documentação e Informação. Arquivo da Câmara dos Deputados. Brasília. Consultado em fevereiro de 2009.

${ }^{269}$ Petição da câmara municipal de Aiuruóca. 09 de janeiro de 1845. Centro de Documentação e Informação. Arquivo da Câmara dos Deputados. Brasília. Consultado em fevereiro de 2009. 
constitucionais, sentimentos estes próprios do gênio e caráter dos mineiros, que esperançosos de serem bafejados de vossas sábias deliberações, aguardam um futuro feliz e o cúmulo de sua prosperidade. ${ }^{270}$

Um sentimento renovado de paz e felicidade já se fazia presente na vida dos brasileiros, como um presságio dos tempos de prosperidade que o futuro guardava para o "Império de Santa Cruz". O apego às instituições monárquicas era reafirmado pelos peticionários; cabia agora aos seus representantes levar sua obra libertadora adiante, resgatando aquilo que havia sido pactuado na sagrada Constituição. De acordo com este ideário, os vereadores do município mineiro de Santa Rita do Presídio diziam ter "íntima convicção que denodados campeões da liberdade e acérrimos propugnadores dos direitos civis e políticos de vossos comitentes," como eram os eleitos da nação brasileira, jamais consentiriam "que mãos sacrílegas toquem a Arca Santa da Constituição e menos que ousem desmoronar o Régio e Augusto Trono do Brasil." Adoradores das instituições monárquicas, os munícipes de Santa Rita dedicavam aos representantes da nação "sua adesão e tênue préstimo, na honrosa missão de que vos achais encarregados." 271

Demonstrando seu apoio à nova legislatura dominada por liberais, os peticionários luzias elaboravam uma forma de influenciar seus representantes a considerar suas demandas já expressas em 1842. A rebelião ficava para trás, evidentemente; mas de forma alguma era esquecida. A lembrança de suas causas era o segundo elemento que compunha a argumentação das câmaras paulistas e mineiras em 1845. No discurso peticionário, a felicidade presente era contraposta a um passado atribulado, que não poderia ser esquecido para que não viesse a se repetir. A câmara municipal de Montes Claros, Minas Gerais, fez, de maneira sutil, uma comparação entre a esperança do presente e o desespero do passado:

se vossa reunião é em todos os tempos um motivo de júbilo e de esperanças para o país, quanto maior não deve ser este júbilo, quanto mais extensa esta esperança, quando depois do glorioso ato de $24 \mathrm{de}$ maio de 1844 aparece vossa reunião, que é a dos verdadeiros escolhidos da Pátria, por virtude de um voto livre, que pôde a Nação por esta vez realizar! Este ato, Augustos e Digníssimos Senhores, é sem dúvida um favor da providência, que depois de tão amargas

\footnotetext{
${ }^{270}$ Petição da câmara municipal de Santa Maria de Baependi. 13 de janeiro de 1845. Centro de Documentação e Informação. Arquivo da Câmara dos Deputados. Brasília. Consultado em fevereiro de 2009.

${ }^{271}$ Petição da câmara municipal de Santa Rita do Presídio. 13 de janeiro de 1845. Centro de Documentação e Informação. Arquivo da Câmara dos Deputados. Brasília. Consultado em fevereiro de 2009.
} 
experiências se dignou volver suas vistas para uma Nação de há muito ludibriada e calcada em seus direitos! Possa a pátria contar o futuro brilhante que lhe augura tão acertada eleição realizando-se a estabilidade do Sistema Representativo como se acha consagrado no Pacto Fundamental do Império. ${ }^{272}$

As esperanças de um futuro melhor se baseavam na necessária extinção do legado deixado pelo domínio da Oligarquia, das "amargas experiências" pelas quais o Brasil passara nas mãos dos regressistas. Não por acaso, a petição da câmara de Taubaté execrava o gabinete de 23 de março ao passo em que pedia aos verdadeiros representantes da nação remédio para os males do Império:

a Nação, revestida de sua soberania e a apelo do poder, colocou-vos presentemente no santuário da confecção das leis, fazendo assim triunfar as idéias e política do mesmo poder, que hoje se vê circundado de vós e da grande maioria do Nacional. Esta só idéia, Senhores, é o mais firme garante da aparição de uma nova época para o Brasil, da qual datará não só a reassunção de seus foros, como a estabilidade de seu futuro engrandecimento e prosperidades. (...) Senhores, permiti que se diga, o Brasil apenas está desafrontado dos terríveis golpes dessa política felizmente decaída graças ao atual governo: mas pertence ainda à vossa sabedoria e patriotismo fechar a abóbada do edifício, curando com leis homogêneas com a Constituição os males que ainda sobrecarregam o Brasil e preservando este de recaída: assim, Senhores, preenchida ficará a expectação nacional; e a posteridade feliz, lendo com respeito na história de nossos dias os nomes de seus regeneradores, os abençoará para sempre. $^{273}$

Nessas petições, paulistas e mineiros davam sua versão própria da história recente do Império. Segundo os peticionários de Pouso Alegre, as "voragens das paixões políticas, que o infrene interesse de mal-entendida conservação pessoal, a despeito do amor à Pátria, soube arteiramente criar," haviam causado a guerra civil que devastara as duas províncias. Felizmente, um novo período se abriu, "representado pelo amor à Pátria, à Religião e à Monarquia Constitucional." Por esta razão, os verdadeiros representantes da nação obrariam para "a consecução do grande fim - firme adesão à Constituição jurada e à Sua Majestade o Senhor Dom Pedro Segundo, sagrados penhores de nossa existência política - por meio de atos legislativos que constituem vossa alta e sublime missão."274

\footnotetext{
${ }^{272}$ Petição da câmara municipal de Montes Claros. 11 de janeiro de 1845. Centro de Documentação e Informação. Arquivo da Câmara dos Deputados. Brasília. Consultado em fevereiro de 2009.

${ }^{273}$ Petição da câmara municipal de Taubaté. 07 de fevereiro de 1845. Centro de Documentação e Informação. Arquivo da Câmara dos Deputados. Brasília. Consultado em fevereiro de 2009.

${ }^{274}$ Petição da câmara municipal de Pouso Alegre. 28 de janeiro de 1845. Centro de Documentação e Informação. Arquivo da Câmara dos Deputados. Brasília. Consultado em fevereiro de 2009.
} 
O quadro traçado pelas câmaras municipais de São Paulo e Minas era bem claro: o passado era sombrio e deveria ser superado; o presente, que afigurava um futuro brilhante, era o tempo da afirmação da liberdade dos brasileiros. O regime monárquico fora deturpado: cabia aos verdadeiros representantes da nação, eleitos após a saída dos regressistas, restabelecer sua verdade. Eis como tais elementos apareciam no discurso de uma petição vinda da câmara de Sorocaba, centro do levante liberal na província de São Paulo e terra de seu principal líder, Rafael Tobias de Aguiar:

na verdade, qual será o brasileiro que deixe de ufanar-se e eletrizar-se de contentamento vendo em vós a imagem viva das Liberdades pátrias e o antagonismo perfeito do absolutismo e despotismo que, por mais de uma vez, têm anelado com ânsia e sofreguidão devorar os filhos da Terra de Santa Cruz?

(...) Augustos e Digníssimos Senhores Representantes, se a Coroa, livrando-se do enorme e pesado jugo dos homens que só desejam escravizar a Nação e desdourar e embaciar o brilho e esplendor do Trono, salvou o Brasil no dia 02 de fevereiro de 1844, dia sem par, dia de tantas venturas, salvou a Liberdade do Povo e as Prerrogativas da Coroa, a vós cabe completar tão grande Obra, consolidando uma e outra coisa. ${ }^{275}$

Absolutismo, despotismo e escravidão eram antinomias do regime constitucional. Consciente disso, D. Pedro II havia destituído o odioso gabinete que sufocara, por tanto tempo, a liberdade na "Terra de Santa Cruz". A tarefa dos eleitos da nação seria, segundo este ponto de vista, dar continuidade a tão gloriosa obra. A exemplo dos sorocabanos, outras petições explicitamente adotavam o discurso dos rebeldes de 1842 e não se vexavam de apontar o dedo contra os opressores de outrora. Os vereadores da vila de Queluz, província de Minas Gerais, diziam que, mais do que nunca, a reunião dos deputados gerais era aguardada por todos os brasileiros posto que o Império acabara de sofrer "todas as calamidades que podem dilacerar uma Nação." Ansiavam os peticionários pela consolidação do sistema monárquico constitucional "tão abalado pelos inimigos do Trono e da Nação" - e pela cicatrização das "profundas feridas que a Oligarquia abriu no coração da pátria."276

A figura da Oligarquia, fantasma que assombrara os peticionários já em 1842, reaparecia nas petições de 1845 que, apesar de se inserirem num contexto diferente e de portarem um tom mais moderado, ainda traziam as marcas de sua origem. A grande diferença, no entanto, estava no fato de que em 1845 a elite política luzia podia ver

${ }^{275}$ Petição da câmara municipal de Sorocaba. 06 de fevereiro de 1845. Centro de Documentação e Informação. Arquivo da Câmara dos Deputados. Brasília. Consultado em fevereiro de 2009.

${ }^{276}$ Petição da câmara municipal de Queluz. 28 de janeiro de 1845. Centro de Documentação e Informação. Arquivo da Câmara dos Deputados. Brasília. Consultado em fevereiro de 2009. 
esperanças quanto ao futuro, pois que o gabinete e a Câmara de maioria liberal estavam, pensavam eles, livres da sanguinária facção que tomara conta do país desde a queda de Feijó. As semelhanças e as diferenças entre o ideário rebelde de 1842 e a atividade peticionária de 1845 ficavam evidentes no discurso adotado pela câmara do município mineiro de Campanha:

a reunião dos escolhidos e procuradores de um povo é sempre motivo de júbilo e geral satisfação; mas quando ela tem lugar depois de longos sofrimentos, quando esse povo cansado de lutar em balde com tantas dificuldades, e de ser contrariado em sua vontade pelos entraves e embates de uma facção poderosa, ardilosa e cheia de recursos, que lhe expõem obstáculos à manifestação de seus votos; por isso mesmo quem as não escrupuliza, habituada a ocupar as melhores posições da sociedade, tinha perdido todas as esperanças de ter legítimos procuradores que advogassem seus direitos conculcados iniquamente e sem recurso, é sem dúvida essa reunião um fato tão extraordinário, tão importante e tão unicamente lisonjeiro, que esse povo prorrompe como que eletricamente em explosões de seu entusiasmo.

É este o espetáculo que apresenta hoje o Povo Brasileiro! Ao ver-vos reunidos, ele de todas as partes do Império, nos excessos de seu transporte brada - já temos uma Representação Nacional, já temos Pátria, já temos garantias, já temos quem se condoa de nossas desgraças, já temos procuradores legítimos que pleiteiam a nossa causa, que é a da justiça e da razão: apressemo-nos pois a saudar os nossos legítimos representantes ao entrarem no pórtico do Santuário das Leis e a lhes ofertar puras oblações, cândidos votos da mais extremada confiança. (...) [A população de Campanha], unindo suas vozes às do Brasil inteiro, vos pede que salveis esta Pátria, que é também a vossa e de vosso adorado Monarca, esta Pátria que homens ingratos têm querido abismar para cevar seus ódios, paixões particulares e ignóbeis e satisfazer as exigências de sua sórdida cobiça e sede de mando. Em vossas mãos, Senhores, está a conjura da tempestade que ameaça tão grandes males ao Império: medidas eficazes ditadas pela vossa sabedoria e seladas com o cunho de vossa prudência é o que o Brasil inteiro com os olhos fitos em vós reclama instantaneamente de seus legítimos Representantes. ${ }^{277}$

Jubilosos por enxergarem na Câmara "procuradores legítimos" do povo brasileiro, os luzias aguardavam ansiosos. Apesar de saberem que se encontravam em contexto diferente daquele de 1842, os peticionários de Minas e São Paulo não abandonavam seus ideais. $\mathrm{O}$ feroz ataque que desferiam contra a Oligarquia e a demonstração de esperança quanto a mudanças futuras comprovavam que os liberais mineiros e paulistas não aderiram ipso facto à posição dos vitoriosos na arena militar.

A ligação entre os peticionários de 1845 e os rebeldes de 1842 ficava mais explícita quando, em meio às felicitações e juras de lealdade feitas à nova maioria,

277 Petição da câmara municipal de Campanha. 15 de janeiro de 1845. Centro de Documentação e Informação. Arquivo da Câmara dos Deputados. Brasília. Consultado em fevereiro de 2009. 
apareciam justificavas do conflito armado. Eis um trecho de uma petição elaborada pela câmara municipal de Oliveira, província de Minas Gerais, que evidenciava a ligação entre o levante e a atividade peticionária:

a só lembrança de que se sentam nos bancos da Representação Nacional os mais fulgurantes ornamentos da tribuna brasileira, que o patriotismo e a inteligência foi o voto espontâneo da Nação em seu estado normal, voto que não seria legítimo se estivesse em estado excepcional, se se achasse convulsa, desmoralizada pelas Revoluções ainda palpitantes e a população dividida em vencedores e vencidos; sim, só esta recordação suave era um balsamo bastante, para curaremse as chagas tão cruelmente abertas em o coração da Pátria pelas mãos dos antípodas de nossa prosperidade: mas, Augustos e Digníssimos Senhores Representantes da Nação, males tão profundos demandam de vós mais prontas e eficazes medicamentos: embora doutrinem que não podemos fazer sentir os sofrimentos dos cidadãos, sentinelas da Constituição, que somos, símplices cidadãos, exercemos um direito, garantido pelo Pacto Fundamental, levando nossas súplicas ao Poder Legislativo.

Cheios de horror encaramos nossos pulsos ainda rasos dos ferros com que nos manietaram essas ferrenhas leis já conspurcadas em sangue!! De vossa prudência esperamos a modificação delas. ${ }^{278}$

O despotismo havia sido vencido, contudo sua lembrança ainda se materializava nas "leis reacionárias" que marcavam de ferros o pulso dos brasileiros. Seria missão dos representantes da nação, naquele ano de 1845, apagar esta lembrança ao demolir a odiosa construção erguida pela dominação regressista. As petições demonstravam que, por mais que o plano rebelde de 1842 houvesse malogrado, a luta contra a política do gabinete de 23 de março era mais resistente ao tempo do que o conflito armado demonstrara. Tanto assim que as demandas de 1842 eram repetidas e, algumas vezes, mesmo ampliadas pelas câmaras municipais em 1845. Os vereadores do município paulista de Cananéia, por exemplo, acreditavam que a Câmara, "utilizando-se das faculdades que lhe concede a lei de seu regimento, assim como tem de promover os meios de sustentar a felicidade pública," empreenderia naquele ano de 1845 "a reforma por que devem passar leis englobadamente discutidas e apaixonadamente votadas, para que reconstituída completamente a Constituição faça a felicidade geral do Império." 279 Vislumbra-se aí a finalidade prática das petições que as câmaras municipais dominadas pelo ideário luzia enviaram aos representantes da nação: a obtenção da reforma ou revogação de certas leis.

278 Petição da câmara municipal de Oliveira. 12 de janeiro de 1845. Centro de Documentação e Informação. Arquivo da Câmara dos Deputados. Brasília. Consultado em fevereiro de 2009.

${ }^{279}$ Petição da câmara municipal de Cananéia. 12 de fevereiro de 1845. Centro de Documentação e Informação. Arquivo da Câmara dos Deputados. Brasília. Consultado em fevereiro de 2009. 
Por trás do discurso dos peticionários de 1845 estava a pressão para que o legado regressista fosse desmantelado. Neste sentido, a petição da câmara municipal de São Luiz, província de São Paulo, era clara:

Senhores, se o Brasil sempre olhou esperançoso para a reunião de seus escolhidos afim de o salvar, ou melhor, à sua sorte, hoje mais que nunca acredita ele achar em vós os meios salutares, que a restituam a seu estado normal, fazendo desaparecer de uma vez por todas os vestígios da prepotência do domínio exclusivo, que por espaço de quase três anos o abateu, e por pouco não lhe extinguiu todos os espíritos vitais. Este restabelecimento pois não pode verificar-se se não empreenderdes a reforma das Reformas naquela parte que direta e escandalosamente ataca os princípios constitucionais. Vós sabeis, Senhores, que foi este procedimento descomunal que feriu a grande artéria do melindre nacional e conflagrou duas províncias importantes do Império. Portanto, de vós esperamos arredeis o mal que ainda sobre nós pesa e, melhorando todos os ramos da pública administração, fazei que o Brasil presente e o Brasil futuro vos cubram de bênçãos pelos benefícios de que é merecedor. São estes os votos desta câmara municipal e de todo o país que vos elegeu. ${ }^{280}$

Aparece, assim, o terceiro elemento que compunha as petições de mineiros e paulistas em 1845. Muitas petições trataram diretamente dessas leis, apontando aos deputados gerais o caminho que deveriam seguir ao revisá-las.

A câmara municipal da vila da Constituição ${ }^{281}$ certa de que vós aplanareis as dificuldades e incômodos que sofre o Povo Brasileiro, tudo devido aos manejos e tramas urdidos pela Oligarquia que por espaço de tempos dominou o Império; levanta os mais fervorosos votos à Providência para que sábias determinações saiam do seio dessa Representação, mormente para a abolição da Lei que reformou o Código de Processo Criminal e daquela que criou um Conselho de Estado. ${ }^{282}$

Do mesmo modo, a câmara municipal de Porto Feliz, província de São Paulo, dizia que de seus representantes esperava "a nação remédio aos males que a oprimem" e, baseada nesta esperança, pedia "a revogação, ou pelo menos a modificação, da Lei das Reformas Judiciárias que tanto coartou as liberdades do povo, e que também vos digneis a fazer uma lei que regule as eleições de maneira que elas sejam sempre feitas com plena liberdade." Esperavam os vereadores de Porto Feliz que, "coadjuvados por

\footnotetext{
280 Petição da câmara municipal de São Luiz. 27 de janeiro de 1845. Centro de Documentação e Informação. Arquivo da Câmara dos Deputados. Brasília. Consultado em fevereiro de 2009.

${ }^{281}$ Atualmente Piracicaba, SP.

282 Petição da câmara municipal da vila da Constituição. 16 de fevereiro de 1845. Centro de Documentação e Informação. Arquivo da Câmara dos Deputados. Brasília. Consultado em fevereiro de 2009.
} 
um governo justo," os representantes da nação consolidassem, “por meio de leis sábias, a monarquia representativa outorgada pela Constituição do Estado.”283

A luta contra as reformas do Regresso se constituiu na maior bandeira dos luzias na década de 1840: assim como havia feito em 1842 a Assembléia Provincial de São Paulo, no ano de 1845 uma multidão de câmaras municipais demandou a revisão das "leis reacionárias" aos representantes da nação. A câmara municipal de Itu, "convencida de que todas as leis que ferem a Constituição do Estado são improfícuas à prosperidade do mesmo" e convencida de que "as Reformas do Código de Processo Criminal, a que criou o Conselho do Estado e a da Interpretação do Ato Adicional pecam nesse sentido," pedia "a revogação de tais leis em tudo quanto se opõem à Lei Fundamental do Império, de cuja inviolabilidade só pode nascer o engrandecimento e glória do povo brasileiro." Assim fazia a elite política do importante município paulista pois estava "cheia de toda a confiança que pode inspirar uma Câmara onde reside a sabedoria e o zelo pela felicidade da Nação." 284

A exemplo do que fizeram os ituanos, os vereadores de Campinas também atacaram aquela trinca de leis: "esta câmara faltaria ao seu mais sagrado dever", diziam os vereadores campineiros, "se não impetrasse dessa Augusta Câmara a ab-rogação do que em sua sabedoria achasse ofensivo à Constituição nas Leis da Reforma do Código, Conselho de Estado e Interpretação do Ato Adicional." Diziam ainda aos deputados gerais que os males que tais leis causavam ao Brasil seriam "a causa de sua ruína inevitável se vós não remediardes esses males que a promovem." Contudo, os campineiros não se restringiram a estas demandas somente e, aproveitando a oportunidade, buscavam a modificação das imposições fiscais para que "a nação não gema debaixo dum ônus insuportável e que, livre os ramos da riqueza pública de tantas peias, possam desenvolver-se e aumentar-se debaixo de leis sábias, providentes e econômicas que levem a nação a um grau de grandeza e prosperidade."285

A câmara municipal de Cunha, que já peticionara em 1842, também trazia amplas demandas em 1845: "cônscia dos sentimentos dos habitantes de seu município, por si, e pelos mesmos, reverentemente se anima a implorar-vos que lanceis vossas sábias vistas sobre as leis das Reformas Judiciárias, Conselho de Estado e dos pesados

\footnotetext{
283 Petição da câmara municipal de Porto Feliz. 15 de fevereiro de 1845. Centro de Documentação e Informação. Arquivo da Câmara dos Deputados. Brasília. Consultado em fevereiro de 2009.

${ }^{284}$ Petição da câmara municipal de Itu. 16 de março de 1845. Centro de Documentação e Informação. Arquivo da Câmara dos Deputados. Brasília. Consultado em fevereiro de 2009.

${ }^{285}$ Petição da câmara municipal de Campinas. 08 de janeiro de 1845. Centro de Documentação e Informação. Arquivo da Câmara dos Deputados. Brasília. Consultado em fevereiro de 2009.
} 
tributos que afligem o povo." Os cunhenses não paravam por aí: “e bem assim sobre a das eleições, que bem regule as mesmas e as ponha a salvo das influências do poder." Esperavam eles que os representantes da nação legislassem "com justiça a prol dos interesses nacionais, da consolidação do Trono Augusto do nosso adorado monarca o Senhor D. Pedro II e das instituições juradas." E, finalmente, conclamavam: "que a Constituição seja hoje uma realidade e não um simulacro de Constituição: por tantos e tão grandiosos benefícios toda a nação vos bendirá e saudará com eterno reconhecimento como fiéis legisladores e liberais defensores de seus direitos."286 Os vereadores da cidade mineira de Pirapora fizeram demandas muito próximas daquelas da câmara de Cunha: depois de exprimirem suas esperanças de que "por meio de leis sábias" os deputados gerais obrassem para que fossem "restituídas as liberdades públicas garantidas pela Constituição e coartadas pela Lei da Reforma Judiciária,” também demandavam "uma lei que regule as eleições de maneira que elas sempre sejam feitas com plena liberdade do povo." 287

Outras demandas ainda foram acrescentadas nas petições, como uma lei de sesmarias ou a reforma da Guarda Nacional. Sobre o primeiro caso, a câmara municipal de Itapeva da Faxina, província de São Paulo, pedia, além da "revogação ou ao menos modificação da Lei das Reformas Judiciárias, com as quais a nação não simpatiza," uma "lei que regule as eleições atenta à plena liberdade de que devem ter os cidadãos" e "uma lei de sesmaria dos terrenos devolutos a fim de cessar tantas dúvidas e intrigas que têm dado lugar a imensos assassínios." 288 Sobre a Guarda Nacional, as câmaras paulistas de Pindamonhangaba e de Guaratinguetá se pronunciaram: a primeira dizia-se desejosa de ver "respeitada a Constituição Política do Império sendo modificada a Lei de 03 de dezembro de 1841," que reformara o Código de Processo Criminal, "com que homens ambiciosos pretendiam tudo chamar ao centro de seus interesses," e também reformada a Guarda Nacional, fazendo-a "como deve ser uma das mais firmes garantias das liberdades públicas. "289 A segunda, exultante pela reunião da Câmara de maioria liberal - "eleita pelos livres sufrágios do Povo" -, pedia uma lei que reformasse "a

\footnotetext{
${ }^{286}$ Petição da câmara municipal de Cunha. 07 de fevereiro de 1845. Centro de Documentação e Informação. Arquivo da Câmara dos Deputados. Brasília. Consultado em fevereiro de 2009.

${ }^{287}$ Petição da câmara municipal de Pirapora. 04 de março de 1845. Centro de Documentação e Informação. Arquivo da Câmara dos Deputados. Brasília. Consultado em fevereiro de 2009.

${ }^{288}$ Petição da câmara municipal de Itapeva da Faxina. 17 de fevereiro de 1845. Centro de Documentação e Informação. Arquivo da Câmara dos Deputados. Brasília. Consultado em fevereiro de 2009.

${ }^{289}$ Petição da câmara municipal de Pindamonhangaba. 21 de janeiro de 1845. Centro de Documentação e Informação. Arquivo da Câmara dos Deputados. Brasília. Consultado em fevereiro de 2009.
} 
Guarda Nacional, uma das garantias das liberdades constitucionais," e também a modificação, "segundo os ditames da justiça e da razão, das leis das Reformas Judiciárias e do Conselho de Estado." Sendo que, a necessidade mais urgente, acreditavam os peticionários de Guaratinguetá, dizia respeito à modificação por que passara o Código de Processo Criminal, transformado pelo gabinete de 23 de março numa "rede de ferro com que homens sedentos do poder pretendiam tudo arrastar a um centro, imolando vítimas ao interesse e ao capricho e atacando os princípios mais categóricos da ordem pública."290

Todas essas demandas se relacionavam na medida em que se constituíam, segundo o ideário das câmaras luzias, como o meio de se curar as desgraças às quais a Oligarquia submetera o povo brasileiro. Depois de deixar claro que acreditavam na legitimidade de seus representantes eleitos em 1844, nada mais natural para as elites políticas de Minas e São Paulo do que levar-lhes suas demandas por reforma. Um tempo de opressão ficara para trás e uma nova era de harmonia entre representantes e representados se afigurava para o Império: dentre todos os peticionários luzias de 1845 , os vereadores de São José, província de Minas Gerais, foram os que explicitaram melhor este sentimento.

Sim, Augustos e Digníssimos Senhores, com afoiteza o diz esta câmara, hoje o Brasil inteiro vos considera a tábua de sua salvação, o remédio de seus aflitivos males. Colocado sobre o mais opulento torrão de América, e talvez do universo, com mágoa ele se vê em luta com a indigência debaixo de um governo essencialmente livre. Com angustia ele se vê agrilhoado por essas denominada Leis de Reforma [do Código], do Conselho de Estado e Eleições, que falando reverente tanto falseiam ao sistema que felizmente nos rege: ou já arrancando direitos sagrados do cidadãos ou pondo peias a sua execução ou já centralizando os Poderes Políticos do Estado, cuja independência política, se não constitui a essência de nossa forma de governo, é entretanto a mais poderosa salvaguarda das liberdades públicas: ou já finalmente restringindo o exercício dos mais preciosos direitos da Coroa, contando com incomensuráveis recursos, pesaroso ele se vê carregado de onerosos e prejudiciais impostos e observa o pouco lisonjeiro estado de suas relações externas pelos embaraços que criaram administração [ilegível], ou que não buscaram remover e que hoje difícil é saná-las. Mas agora que, felizmente, esta câmara e o Brasil todo contempla no seio da Representação Nacional cidadãos prestantes, adornados de todas as virtudes cívicas que mais de uma vez se hão tanto distinguido pelos seus esforços a prol da salvação da Pátria; hoje, que a Opinião Pública fala pela boca de seus Legítimos Representantes, quem com esta câmara não nutrirá fundadas esperanças? Quem não preverá o venturoso porvir que espera o

\footnotetext{
${ }^{290}$ Petição da câmara municipal de Guaratinguetá. 22 de janeiro de 1845. Centro de Documentação e
} Informação. Arquivo da Câmara dos Deputados. Brasília. Consultado em fevereiro de 2009. 
Brasil? [ilegível] uma nova época mostrou-se para nossa idolatrada pátria. A sua regeneração no sentido de seu melhoramento vai ser uma realidade. Esta câmara com prazer o repete: o Brasil vos considera a sua tábua salvadora, o remédio de seus males; ela por isso vos dirige suas sinceras e cordiais felicitações e congratula-se com o Brasil por possuir uma Câmara verdadeiramente nacional, composta das notabilidades do país, uma Câmara cujo distintivo é coadjuvar francamente a um Governo consciencioso e realmente nacional na difícil quanto gloriosa tarefa de salvar ao País e de elevá-lo ao apogeu da glória e opulência a que parece destinado pelos Altos Poderes. ${ }^{291}$

Aproveitando-se da oportunidade que se abria, os luzias colocavam suas demandas por transformação. A tábua salvadora da nação: eis como eles viam a maioria liberal eleita pelo povo brasileiro. Já em 1842 esta idéia havia sido abraçada pelos descontentes peticionários paulistas que lutavam contra o gabinete de 23 de março. Este, porém, se antecipara e obrara para a dissolução da Câmara eleita sob o domínio dos maioristas antes que ela pudesse receber as queixas. Todavia, em 1845 a representação nacional pudera se estabelecer e os abutres da Oligarquia não mais rapinavam pelos céus brasileiros. Ao enxergarem no centro do poder uma Câmara que consideravam legitimamente eleita, um ministério de patriotas e um monarca protegido do despotismo, os peticionários luzias acreditavam que, enfim, poderiam ver os princípios da liberdade e da justiça fixados em todo o Império.

Como já ficou demonstrado, as câmaras municipais mineiras e paulistas criaram, a partir de suas petições, uma interpretação dos acontecimentos políticos da década de 1840 e, a partir dela, reconstruíram seu projeto de reformas. A câmara de Mariana, por meio de duas petições que foram enviadas juntas aos deputados gerais em 1845, foi responsável por amalgamar todos os elementos componentes da estratégia política luzia. Na primeira delas lia-se:

nunca desde a época feliz em que pela vez primeira foi aberto o Parlamento Brasileiro pelo Augusto Fundador do Império foi tão esperançosa a reunião dos mandatários do povo como no $1^{\circ}$ de janeiro deste ano. Depois de tantas calamidades por que tem passado o Brasil não pode deixar de ser saudada, entre os mais vivos transportes de júbilo, a Aurora do grande dia, precursor de tanta ventura. O Povo Brasileiro, tratado como uma horda de escravos por uma facção inimiga declarada da Luz e da Liberdade, sacrificado à raiva indomável de seus Verdugos, em grandes quadrilhas, espalhadas pelas províncias deste malfadado Império, vendo a cada momento extinguirse o último raio de esperança, tão brilhante nos dias felizes de sua emancipação política; hoje vos saúda; vos felicita pela sua tão inspirada reunião no Santuário das Leis!

291 Petição da câmara municipal de São José. 17 de fevereiro de 1845. Centro de Documentação e Informação. Arquivo da Câmara dos Deputados. Brasília. Consultado em fevereiro de 2009. 
Os Céus ouviram; deixaram-se tocar; enterneceram-se com as lágrimas, com os suspiros, com o abandono das consortes, dos filhos, das viúvas e dos órfãos, que a sanha dos nossos inimigos, quais tigres da Hircânia, haviam devotado à sua insaciável cobiça de mando e de dinheiro. Não era possível que tanto sangue derramado em holocausto do Trono e da Liberdade do Império de Santa Cruz ficasse silencioso. $\mathrm{O}$ anjo tutelar do Brasil subtraído pela mão invisível da Providência desse círculo de ferro, onde não podia ouvir os brados de tantas vítimas imoladas em defesa dos mais sagrados direitos, salvou com o seu Trono as instituições livres, pela Nação juradas e com tantos sacrifícios sustentadas graças ao Imortal Imperador o Senhor D. Pedro Segundo, graças à Nação, que soube tomar a atitude de soberana e esmagar para sempre a hidra que quase nos havia devorado. Mostrai por vossos atos, Augustos e Digníssimos Senhores Representantes da Nação, que a Constituição vai ser uma realidade no nosso solo. Pois é este o voto do Brasil, principalmente do município de Mariana, que os abaixo-assinados tem a honra de representar. ${ }^{292}$

Após a narrativa sobre o passado nacional e a felicitação pela presente reunião

dos legítimos representantes, vinha, em petição anexa, um plano de ação política para o futuro político do Império:

a câmara municipal da Leal cidade de Mariana, convencida de que o Povo Brasileiro tem sofrido de tempos a esta parte a opressão mais tirânica que algumas leis têm consagrado, julgou de seu rigoroso dever manifestar-vos a necessidade de uma pronta revogação e, por isso, em sessão extraordinária no dia 20 de fevereiro, que se vos representasse, em nome de seus munícipes, que compartilham o sentimento de toda a Nação, tão dignamente por Vós representada.

É opinião geral que a Lei que interpretou o Ato Adicional aniquilou direitos e garantias, que só uma Assembléia Constituinte podia aniquilar pela competência de seu mandato; ficando assim completamente iludidas as esperanças dos verdadeiros Patriotas e ferida profundamente a Carta da Lei de 12 de agosto de 1834 que as províncias aceitaram com tanto prazer, quantos foram os sacrifícios e trabalhos para conseguir.

A Lei que reformou o Código do Processo Criminal abertamente violou a Constituição, ferindo-a na parte mais essencial. Esta Lei foi proclamada em um campo ensopado de sangue, por entre os alaridos daqueles Brasileiros desnaturalizados, que entendiam poder escravizar seus Irmãos, policiando-os com o bacamarte, com o punhal e com a trela. A última Lei de impostos matou a agricultura, a indústria e o comércio. O Brasil estava a despenhar-se de um abismo de desgraças se não fosse visivelmente protegido pela Providência. Leis tais devem ser abolidas em satisfação à Constituição tão ultrajada. É tempo, Augustos e Digníssimos Senhores Representantes da Nação, de mostrardes a todo o Brasil que a Liberdade e o Trono têm em Vós defensores denodados e sinceros. É tempo de dar-se a este bom Povo Brasileiro o que há tanto tempo e tão liberalmente lhe promete a Constituição.

${ }^{292}$ Petição da câmara municipal de Mariana (1). 20 de fevereiro de 1845. Centro de Documentação e Informação. Arquivo da Câmara dos Deputados. Brasília. Consultado em fevereiro de 2009. 
A câmara municipal de Mariana espera do vosso Patriotismo que semelhantes Leis serão retocadas: assim esperam todos os vossos constituintes e especialmente deste município. ${ }^{293}$

Apesar das diferenças que guardavam entre si, as 34 petições luzias referentes ao ano de 1845 compunham um grupo homogêneo, portador de um discurso único que tinha como objetivo central a revisão das "leis reacionárias". Dentre estas tão odiadas leis, uma se destacava pela insistência com que aparecia: das 34 petições analisadas, 13 declaravam diretamente a qual lei se opunham e todas elas, sem nenhuma exceção, pediam a revogação (ou a modificação) da Reforma do Código de Processo Criminal datada de 03 de dezembro de 1841. A segunda demanda mais freqüente, a revisão da lei que reinstituíra o Conselho, foi manifesta por apenas seis petições. Uma nova lei eleitoral foi pedida por quatro petições, ${ }^{294}$ enquanto a revisão da Interpretação do Ato Adicional foi demandada por três, a diminuição de impostos foi defendida por duas, também duas foram favoráveis a uma reforma da Guarda Nacional e, finalmente, uma petição somente pregou a necessidade de uma lei de sesmarias.

A predominância da demanda pela reforma judiciária não se expressou somente pelos números: também no discurso peticionário notava-se a importância que uma medida modificando a Lei de 03 de dezembro adquiriu para paulistas e mineiros naquele contexto. Tal lei foi pintada como o mais terrível flagelo impingido à nação pelo governo regressista. A câmara municipal da cidade mineira de Pitanguí, que se dizia confiante na "alta sabedoria, patriotismo indubitável e dedicada adesão às pátrias liberdades" que demonstravam os representantes da nação, dizia deles esperar a abrogação da "Lei das Reformas do Código, cujas folhas acham-se avermelhadas com o sangue do brioso Povo de Minas e São Paulo, triste selo que a mão da Oligarquia lhes pusera." Extirpando do "nosso sistema representativo até a última raiz do pernicioso enxerto que lhe introduzira o espírito retrógrado," a Câmara eleita em 1844 haveria "de substituir as supra-ditas por outras, que adequadas às nossas circunstâncias, sanem as lesões feitas à Constituição e reintegrem as exclusivas atribuições da Coroa, que tinham sido prejudicadas. $" 295$ O sangue paulista e mineiro manchara aquela lei. Aos eleitos do

\footnotetext{
293 Petição da câmara municipal de Mariana (2). 20 de fevereiro de 1845. Centro de Documentação e Informação. Arquivo da Câmara dos Deputados. Brasília. Consultado em fevereiro de 2009.

${ }^{294}$ Esta demanda foi atendida pela situação liberal entre 1845 e 1846, conforme ficou demonstrado no capítulo 3 da presente dissertação.

${ }^{295}$ Petição da câmara municipal de Pitanguí. 24 de janeiro de 1845. Centro de Documentação e Informação. Arquivo da Câmara dos Deputados. Brasília. Consultado em fevereiro de 2009.
} 
povo brasileiro cabia, no ano de 1845 , colocar um fim neste elemento de discórdia e desintegração nacional.

O ódio que sentiam as elites políticas paulista e mineira pela Lei de 03 de dezembro se justificava pelo valor que deram, desde a Abdicação, às conquistas dos poderes locais no Império. O Código de Processo Criminal aprovado em 1832 determinara que os juízes de paz, eleitos localmente, teriam amplo campo de ação: eram eles responsáveis por formar culpa, por assinar termos de bem viver e de segurança, por conceder fiança aos declarados culpados no Juízo de Paz e por julgar as contravenções às posturas das câmaras municipais e os crimes cuja pena não ultrapassasse $100 \$ 000$, prisão ou degredo. Os juízes municipais, de acordo com o mesmo Código, seriam nomeados pelo presidente da província a partir de uma lista tríplice elaborada pelas câmaras municipais. $\mathrm{O}$ mesmo procedimento se daria em relação aos promotores e aos juízes de órfãos. Ao imperador - o que, na prática, era feito pelo ministro da justiça caberia nomear o juiz de direito. ${ }^{296}$

Instituição poderosa nos termos do Código de 1832, o conselho de jurados se tornou peça central para a organização judiciária do Império. Todos aqueles que estivessem aptos a exercer o papel de eleitores (ou seja, tivessem renda anual superior a $200 \$ 000$ réis) estariam qualificados para serem jurados. A composição da lista dos cidadãos aptos para o cargo caberia, em cada distrito, a uma junta composta pelo juiz de paz, pelo pároco e pelo presidente da câmara municipal (todos os três autoridades diretamente vinculadas à localidade). $\mathrm{O}$ júri funcionaria em duas instâncias: primeiro, após formada a culpa pelo juiz de paz e enviado o processo à câmara municipal, esta sortearia 60 nomes da lista de jurados. Dos sorteados, 23 comporiam o Júri de Acusação, ao qual competiria decidir se havia ou não matéria para ser julgada. Uma vez pronunciado o réu, o acusador deveria oferecer sua queixa e um segundo júri seria formado por 12 jurados, o Júri de Sentença. Era este órgão que decidiria se o réu seria condenado ou não. Ao juiz de direito caberia apenas aplicar as penas previstas na lei. ${ }^{297}$

De acordo com a historiadora Monica Duarte Dantas, o processo criminal estabelecido pelo Código de 1832 se tratava "de uma justiça cidadã, em que os brasileiros eram julgados por seus pares, cabendo em essência à magistratura togada

\footnotetext{
${ }^{296}$ Monica Duarte Dantas. "O Código do Processo Criminal e a Reforma de 1841: dois modelos de organização do Estado (e suas instâncias de negociação)". Conferência apresentada junto ao $I V$ Congresso do Instituto Brasileiro de História do Direito - Autonomia do direito: configurações do jurídico entre a política e a sociedade. São Paulo: 2009. pp. 3-4.

${ }^{297}$ Idem. Ibidem. pp. 4-5.
} 
apenas a aplicação da pena ou a decisão em nível recursal." ${ }^{, 298}$ Os juízes de fato eram os jurados, cidadãos que assumiam função central na justiça brasileira. Em grande medida, na década de 1830, a administração da justiça esteve nas mãos das iminências locais. A Lei de Reforma do Código de Processo Criminal, datada de 03 de dezembro de 1841, foi responsável por alterar este quadro, retirando atribuições do juiz de paz, esvaziando o papel das câmaras municipais e restringindo a atuação do júri enquanto fortalecia magistrados escolhidos pelo poder central.

Quanto à estrutura policial, a reforma promovida pelos regressistas deu ao ministro da justiça a prerrogativa de nomear os chefes de polícia de cada província. Estes chefes, por sua vez, nomeariam os delegados, subdelegados e substitutos de cada município sob sua responsabilidade. Aos chefes de polícia e aos delegados foram atribuídas funções antes pertencentes ao juiz de paz como formar culpa, obrigar a assinatura de termos de bem viver, julgar as contravenções às posturas das câmaras municipais e julgar determinados crimes. Além disso, foram abolidas as Juntas de Paz. Os juízes municipais passaram a ser nomeados diretamente pelo imperador, abolindo-se a lista tríplice elaborada pelas câmaras municipais, e receberam, a exemplo dos chefes de polícia e delegados, funções que anteriormente competiam aos juízes de paz. O mesmo procedimento foi adotado em relação à escolha dos promotores. ${ }^{299}$

A pronúncia do réu, antes responsabilidade do Júri de Acusação, passou às mãos do corpo policial. Este, por sua vez, passava o processo ao juiz municipal, que podia sustentá-la ou revogá-la. Assim como aconteceu com o juiz de paz, o conselho de jurados perdeu grande parte de suas funções. Abolido o Júri de Acusação, não cabia mais aos cidadãos pronunciar o réu, restando somente o Júri de Sentença. No entanto, mesmo este perdeu parte de sua importância a partir da Lei de 03 de dezembro: as sentenças proferidas pelos jurados se dariam doravante a partir de perguntas feitas pelo juiz de direito. Este mesmo juiz poderia decidir, quando julgasse que a sentença do júri contrariava as evidências apresentadas, acerca da ilegalidade da deliberação. A Reforma de 1841 ainda modificou a formação do conselho de jurados: estabeleceu que os seus membros, além de serem obrigados a saber ler e escrever, deveriam obter $400 \$ 000$ de renda anual nas cidades maiores e $300 \$ 000$ nas cidades menores do Império; e também modificou a junta responsável pela elaboração da lista de jurados, substituindo o pároco

\footnotetext{
${ }^{298}$ Idem. Ibidem. p. 6.

${ }^{299}$ Idem. Ibidem. pp. 10-12.
} 
e o juiz de paz pelo promotor e pelo juiz de direito (ambos delegados do poder central). ${ }^{300}$

A obra do Regresso foi complementada pelo Regulamento n. 120 do ano de 1842. Tal regulamento estabeleceu uma estrutura hierárquica para o Judiciário brasileiro, colocando o ministro da justiça como seu chefe supremo e os presidentes provinciais e chefes de polícia como encarregados de manter a segurança e a tranqüilidade públicas. Definia ainda que chefes de polícia e juízes de direito só poderiam ser nomeados enquanto tais depois de terem servido por mais de três anos em outros cargos da magistratura. Delegados, promotores e outros agentes do poder central só seriam mantidos se servissem convenientemente, podendo ser sumariamente demitidos pelo governo caso assim não procedessem. Nas palavras de Dantas: "o 'Regulamento' deixava mais evidente o que a Lei de 1841 já demonstrava, que da justiça cidadã de 1832 não sobrara quase nada." ${ }^{301} \mathrm{O}$ que ocorreu foi o esvaziamento das funções judiciárias exercidas por autoridades locais como juízes de paz, párocos e vereadores. Além disso, o também esvaziado júri fora colocado sob as asas do juiz de direito, submetido ao poder central. ${ }^{302}$

Dois dias depois de aprovado o Regulamento n. 120, o Poder Executivo - mais especificamente, o gabinete de 23 de março - passou uma medida para que a Reforma fosse imediatamente aplicada. Frente a tal cenário, paulistas e mineiros começaram a demonstrar seu descontentamento: havia o entendimento por parte destas duas elites políticas de que o Regresso iria impor ao país uma dominação antiliberal - a Reforma do Código só fez exacerbar seu temor quando retirou da alçada local funções judiciárias que passaram a ser exercidas por magistrados ligados ao centro. Quando da dissolução de $1^{\circ}$ de maio de 1842 , a ruptura se completou e os descontentes recorreram às armas. A fulminante derrota no campo de batalha não impediu que, poucos anos depois, logo que surgiu uma oportunidade, com a volta dos liberais ao Legislativo e ao Executivo, inclusive com o deputado Antonio Paulino Limpo de Abreu - líder político em Minas Gerais - ocupando o cargo de ministro dos negócios estrangeiros, os representantes eleitos por Minas Gerais e por São Paulo se unissem para reivindicar a alteração da Lei de 03 de dezembro 1841. Por trás de sua atuação estava a veemente atividade peticionária das câmaras municipais de suas províncias.

\footnotetext{
${ }^{300}$ Idem. Ibidem. pp. 11-12.

${ }^{301}$ Idem. Ibidem. p. 14.

${ }^{302}$ Idem. Ibidem. pp. 14-15.
} 
As câmaras municipais, conforme ficou demonstrado, foram prejudicadas pela Reforma do Código na medida em que perderam - junto dos jurados e dos juízes de paz - grande parte da influência que tinham sobre a organização da justiça criminal no Império. Nas províncias de Minas e São Paulo, as câmaras foram, desde o período colonial, importantes instrumentos de exercício de poder das camadas dominantes locais ligadas ao abastecimento interno: a câmara de Sorocaba, por exemplo, esteve fortemente ligada ao pujante comércio de animais que tinha lugar naquela região; já as câmaras de determinadas regiões de Minas reuniam produtores de alimentos comercializados majoritariamente na Corte. ${ }^{303}$ A Lei de $1^{\circ}$ de outubro de 1828 , aprovada pela primeira legislatura nacional, já havia retirado parte das funções políticas historicamente exercidas pelas câmaras municipais, como a nomeação de funcionários e a criação de tributos; em contrapartida, como já ficou demonstrado, o Código de Processo Criminal de 1832 deu às elites municipais ingerência sobre a organização judiciária por meio do fortalecimento dos juízes de paz, da centralidade do júri e da participação dos vereadores no apontamento de magistrados e na formação do conselho de jurados. A Lei de 03 de dezembro de 1841, no entender das elites paulista e mineira, usurpou-lhes os últimos meios de exercer seu poder sobre as populações locais: por isso elas aderiram ao movimento de 1842 e também por isso escreveram as petições em 1845.

O deputado Francisco Álvares Machado de Vasconcelos, logo no dia 18 de janeiro de 1845 enviou à mesa da Câmara um requerimento em que pedia às comissões reunidas de constituição e justiça um "projeto de aperfeiçoamento" da reforma judiciária "em que se elimine o que encontrar-se possa contrário à Constituição.”304 Álvares Machado, segundo conta Joaquim Manuel de Macedo, era um cirurgião de talento que, por meio de seus dotes, estabeleceu importantes contatos em Itu, Porto Feliz e, mais tarde, Campinas, onde se tornou líder político e onde logo foi eleito deputado provincial e também deputado geral. Desde 1838, o paulista se mostrou na Câmara um crítico dos líderes do Regresso: “Álvares Machado flagelou quase três anos a todos eles com a sua inesgotável fonte de ironias,"305 relata Macedo. Líder do

\footnotetext{
${ }^{303}$ Sobre as câmaras municipais paulistas, consultar: Cássia Maria Baddini. Sorocaba no Império: comércio de animais e desenvolvimento urbano. São Paulo: Annablume, 2002; sobre as câmaras municipais mineiras, consultar: Wlamir Silva. Liberais e Povo: a construção da hegemonia liberalmoderada na província de Minas Gerais (1830-1834). São Paulo: Hucitec, 2009.

${ }^{304}$ Anais da Câmara dos Deputados. 18 de janeiro de 1845. p. 230.

305 Joaquim Manuel de Macedo. Suplemento do Anno Biographico Brazileiro. Rio de Janeiro: Typographia Perseverança, 1880. p. 350.
} 
Movimento da Maioridade dentro do parlamento, foi nomeado pelo Gabinete Maiorista presidente do Rio Grande do Sul com a missão de pacificar a província. Eleito para a Câmara no fim do ano de 1840, sofreu duplamente nas mãos do gabinete de 23 de março: não pôde assumir o cargo de deputado por causa da dissolução de $1^{\circ}$ de maio de 1842 e foi retirado de seu posto de presidente provincial. Juntou-se aos rebeldes paulistas e, ao lado do sorocabano Tobias de Aguiar, foi um dos organizadores do movimento armado.

Ao justificar seu requerimento diante de seus pares em 1845, o líder político paulista manifestava seu apoio ao gabinete liberal de 02 de fevereiro e, assim como os peticionários das câmaras municipais, agradecia-o "pela tranqüilidade que deu ao país." Contudo, o deputado paulista também afirmava que a Câmara dos Deputados não ficaria inerte, a espera da ação do Poder Executivo. Caso ele não se empenhasse na tarefa de desfazer o mal trazido pelas reformas regressistas, os próprios representantes da nação se encarregariam de defender no parlamento as mudanças necessárias: "o governo encontrará o meu apoio para tudo quanto de bom apresentar;" - dizia o deputado paulista - "mas eu também hei de apresentar aquilo que a minha consciência e convicção me mover a fazer em benefício do meu país." ${ }^{306}$ Álvares Machado antecipava uma questão que seria fundamental naquela sessão: os deputados de Minas e São Paulo, em comum acordo com as elites políticas de suas províncias, defenderiam a modificação da Lei de 1841; os demais liberais, tanto da Câmara quanto do gabinete de 02 de fevereiro, divididos por pressões diversas, não responderiam, porém, com presteza ao anseio dos ex-rebeldes.

Desde os primeiros dias da legislatura aberta em 1845, os representantes do grupo luzia na Câmara deixaram clara sua posição. O mineiro Fernando Sebastião Dias da Motta acusava o gabinete de 23 de março das mais terríveis injustiças contra o povo brasileiro: "entre elas foram as mais graves: primeiro, não respeitar o importante e sagrado direito de petição. (Numerosos apoiados.) Receber uma petição e não quer referi-la." ${ }^{307}$ Seu exclusivismo, na visão do deputado, tornara-o surdo às aspirações da nação. A crítica aos desmandos da Oligarquia, porém, tinha outro alvo além dos regressistas caídos: o gabinete recém-empossado de 02 de fevereiro que, composto por figuras que se opunham ao Regresso, não deveria medir esforços para contentar as demandas que o país expressara por meio das petições que inundavam o plenário. A

\footnotetext{
${ }^{306}$ Anais da Câmara dos Deputados. 18 de janeiro de 1845. pp. 233-234.

${ }^{307}$ Ibidem. p. 248.
} 
monarquia, a Constituição, a justiça e a liberdade estavam em jogo, cabia aos membros do novo ministério selar a paz com a nação e reconstruir o império da legalidade.

No dia 12 de julho de 1845, as comissões reunidas de constituição e justiça, compostas pelo maranhense Joaquim Franco de Sá, pelo pernambucano Urbano Sabino Pessoa de Mello, pelo fluminense Manoel de Jesus Valdetaro e pelos mineiros Teófilo Benedito Ottoni e José Antonio Marinho (ambos radicais combatentes das fileiras luzias em 1842), apresentaram o projeto requerido pelo paulista Álvares Machado. O único membro das comissões a se colocar como voto vencido contra o projeto foi o liberal paraibano Nicolau Rodrigues dos Santos França Leite, que, quando em pauta a reforma eleitoral, esteve junto de mineiros e paulistas. Dentre as principais medidas propostas no projeto estavam: $1^{\mathrm{a}}$ ) a retirada da jurisdição criminal (inclusive em relação aos crimes contra as posturas das câmaras municipais) e da formação de culpa dos delegados e subdelegados; $2^{\mathrm{a}}$ ) a devolução destas prerrogativas aos juízes de paz; $3^{\mathrm{a}}$ ) o impedimento da intervenção do juiz de direito sobre as decisões do júri, quando fossem unânimes; $4^{\mathrm{a}}$ ) a formulação da lista de jurados por uma junta composta pelo juiz de paz, pelo pároco e pelo eleitor mais votado da localidade; $5^{\text {a }}$ ) a revisão da mesma lista por uma junta municipal composta pelo juiz de direito e pelos dois vereadores mais votados; $6^{\mathbf{a}}$ ) a nomeação pela Coroa dos juízes municipais e de órfãos a partir de uma lista sêxtupla proposta pela câmara municipal da localidade onde os magistrados iriam atuar; $7^{\mathrm{a}}$ ) a limitação da atuação dos juízes municipal e de órfãos à preparação do processo, não podendo mais proferir sentença final nem interlocutória. ${ }^{308}$

Tais medidas, de acordo com o parecer das comissões, visavam "a separação completa entre a polícia e a justiça, restituindo aos ministros desta o que lhes havia sido alheado em favor dos agentes amovíveis daquela" e, no que se referia ao júri, "garantir esta judicatura social contra as invasões da parcialidade e do interesse político, assim do poder como dos partidos e influências locais. ${ }^{\text {309 }}$ O projeto das comissões, apesar de não reverter boa parte das modificações trazidas pela Lei de 03 de dezembro, em boa medida devolvia às autoridades locais e aos jurados o poder que havia lhes sido retirado pelos regressistas e, com isso, controlava a ingerência do governo central sobre a administração da justiça: o juiz de paz retomaria atribuições entregues aos delegados e aos magistrados escolhidos pelo ministério; o júri não ficaria mais completamente à mercê do juiz de direito; autoridades locais (pároco, eleitor e vereadores mais votados)

\footnotetext{
${ }^{308}$ Anais da Câmara dos Deputados. 12 de julho de 1845. pp. 154-156.

${ }^{309}$ Ibidem. p. 154.
} 
voltariam a prevalecer na qualificação dos jurados; as câmaras municipais teriam de volta a influência na escolha (por meio de listas sêxtuplas) que o poder central faria de seus magistrados. Pelo menos em parte as demandas das câmaras municipais de Minas e São Paulo expressas pela atividade peticionária estavam sendo atendidas.

Ainda que a ligação entre as demandas dos ex-rebeldes luzias e a defesa do projeto de reforma judiciária em 1845 fosse clara, alguns deputados daquela corrente fizeram de tudo para afastar de si a pecha de facciosismo. Sua tática consistiu em vincular a demanda pela reforma judiciária a toda a nação brasileira e desvencilhar o movimento de 1842 da proposta de modificação da Lei de 03 de dezembro. Neste sentido, o deputado mineiro Joaquim Antão Fernandes Leão dizia, ao se opor ao pedido de adiamento vindo de um oposicionista, que o projeto representava uma necessidade reclamada por todo o país:

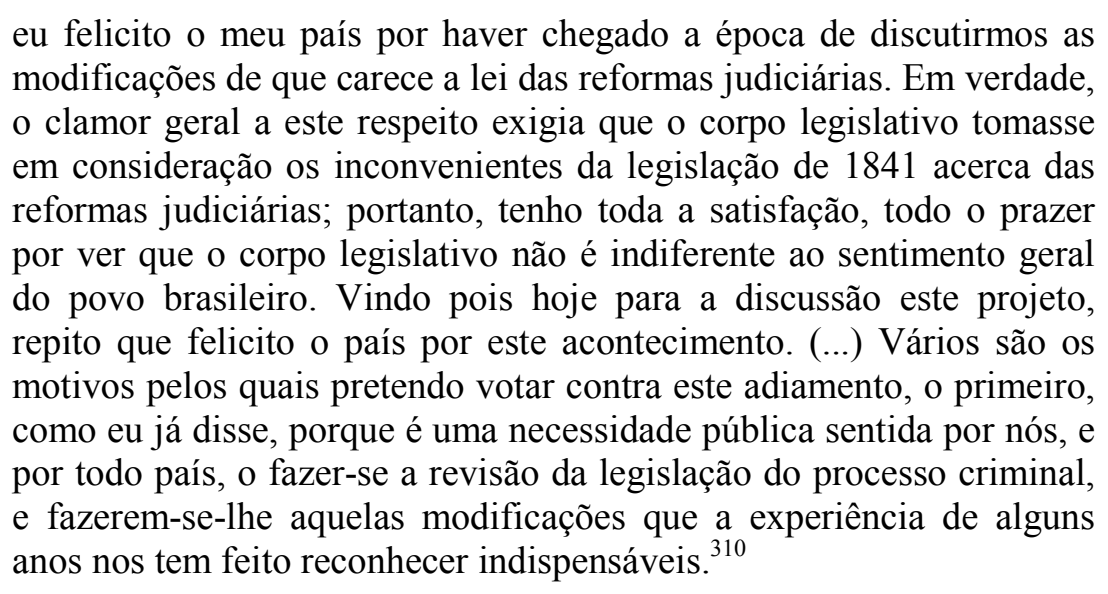

Não somente Minas e São Paulo, mas todo o Brasil requeria a revisão da lei que modificara o Código de Processo Criminal. Antão - mineiro de Queluz, cuja carreira política se iniciara em Ouro Preto, onde exercera os cargos de promotor e inspetor da fazenda ${ }^{311}$ - tinha o maior cuidado em afirmar que o projeto das comissões representava um ajuste daquela lei à Constituição do Império. Os defensores da proposta não eram rebeldes, mas, ao contrário, os maiores defensores da legalidade. Assim se colocou também Álvares Machado, quando declarou que "a Câmara representa o país, o país e a Câmara desejam ver quanto antes reformada uma legislação tirânica, acintemente promulgada no interesse de um partido e para doutrinar e governar o país no sentido do interesse desse mesmo partido." Segundo ele, a nação brasileira de um modo geral desejava "ver o quanto antes abolidos todos esses artigos anticonstitucionais, tirânicos e

\footnotetext{
${ }^{310}$ Anais da Câmara dos Deputados. 30 de julho de 1845. p. 366.

311 Augusto Victorino Alves Sacramento Blake. Diccionario Bibliographico Brazileiro. Quarto volume. Nendeln: Kraus Reprint, 1969. p. 83.
} 
vexatórios" que compunham a Lei de 03 de dezembro de 1841; pois, era ela que, de fato, representava a mesquinhez de uma facção, a facção regressista que se apossara do poder após o Movimento da Maioridade. ${ }^{312}$

Os defensores da reforma, não obstante os esforços de Antão e Álvares Machado, não encontraram o apoio que esperavam por parte dos liberais de outras províncias. Sobre eles pesava a acusação que já haviam previsto. Aproveitando-se da situação, um grupo oposicionista, defensor da política do Regresso - denominado patrulha conservadora por causa da recorrente oposição que faziam às propostas dos liberais - pregava que os representantes de Minas e São Paulo eram os mesmos rebeldes de 1842 , membros de uma facção que fazendo uso da força bruta buscara impor ao resto da nação seu projeto político. O deputado goiano, ex-presidente do Rio Grande do Norte e agora eleito por sua província natal, D. Manoel de Assis Mascarenhas - que sustentara, segundo Joaquim Manuel de Macedo, "a conveniência política da anistia aos comprometidos nas revoltas liberais de $1842^{, 313}$ - se mostrou, na arena parlamento, grande inimigo do projeto luzia. Logo no primeiro dia de discussão da proposta de reforma judiciária, desferiu um dos mais veementes ataques aos deputados de Minas e São Paulo. Segundo ele, o projeto apresentado pelas comissões significava "uma satisfação a um partido a quem se havia prometido solenemente de trabalhar, não pela derrogação, mas pela ab-rogação da Lei de 03 de dezembro de 1841." Continuava:

com efeito, alguns nobres deputados, cheios de remorsos...

O Sr. Presidente: - Eu não posso consentir que o nobre deputado faça estas insinuações a alguns dos nobre deputados.

O Sr. D. Manoel: - É crime dizer-se que um cristão tem remorsos?

O Sr. Presidente: - O nobre deputado não disse só isto; disse que as comissões têm de satisfazer a um partido.

O Sr. D. Manoel: - Eu não disse isto; mas se o disse, sustento. ${ }^{314}$

O presidente da Câmara na ocasião era José Joaquim Fernandes Torres, um importante representante do grupo luzia de Minas Gerais nascido em Mariana e professor do curso jurídico em São Paulo. A discussão entre D. Manoel e Fernandes Torres era apenas uma prévia do que viria a ser o debate em torno da necessidade da reforma judiciária naquele ano de 1845. Enquanto os opositores do projeto argumentavam, incansavelmente, que a ânsia em modificar a Lei de 03 de dezembro se devia ao fato de que uma facção - isto é, a facção luzia derrotada em 1842 - assim o

\footnotetext{
${ }^{312}$ Anais da Câmara dos Deputados. 02 de agosto de 1845. p. 417.

${ }^{313}$ Joaquim Manoel de Macedo. Anno Biographico Brazileiro. Segundo volume. Op. Cit. p. 525.

${ }^{314}$ Anais da Câmara dos Deputados. 30 de julho de 1845. p. 364.
} 
exigia; o presidente Fernandes Torres e seus aliados faziam de tudo para que o debate se restringisse às medidas propostas no projeto.

O deputado goiano, desfilando toda sua ironia, dizia que os deputados mineiros e paulistas deveriam "cumprir fielmente suas promessas, filhas de suas convicções sem dúvida": já que estiveram tão ultrajados a ponto de oferecerem ao país "um protesto armado, que eu chamarei rebelião, contra estas leis de Reforma do Código e do Conselho de Estado," já que "julgaram que era o caso de se levantarem nas províncias, de se rebelarem para deitar abaixo esta lei," deveriam agora ser coerentes com suas ações pretéritas e propor "um simples artigo dizendo: - está revogada a Lei de 03 de dezembro de 1841." Ao término de seu discurso, D. Manoel completava o ataque: "se estas doutrinas passarem, o país voltará ao antigo estado, e (...) o abismo vai abrir-se talvez para a queda do edifício social." ${ }^{315}$ A promessa feita à facção luzia era a defesa da anarquia, segundo o deputado goiano. Satisfazer às demandas dos ex-rebeldes seria uma afronta à boa ordem afirmada nos tempos da dominação regressista, o país retroagiria a um período de agitação social e de desrespeito às leis e à Constituição.

D. Manoel não estava sozinho neste ataque à proposta das comissões, pois a bancada baiana da Câmara se mostrou também ardente defensora da política do Regresso. O deputado conservador João José de Oliveira Junqueira acusava o projeto de ser uma satisfação aos rebeldes derrotados, pois que a Lei de 1841 fora "objeto que deu lugar às províncias lançarem-se no caminho que podia ser muito perigoso." Quando um deputado luzia questionou de quem falava Junqueira, este rapidamente respondeu: "dos Senhores que fizeram o movimento." ${ }^{316}$ Outro deputado baiano, Ângelo Muniz da Silva Ferraz - denominado "chefe da patrulha" ${ }^{317}$ - adotava a mesma estratégia de D. Manoel e dizia ser uma obrigação dos representantes de Minas Gerais e São Paulo defender a reforma judiciária pois, "quando se quer justificar qualquer movimento popular, a única razão que se pode alegar é a necessidade" e esta necessidade que se alegou, "segundo os documentos do tempo, era a existência de uma lei que os nobres membros da maioria diziam inconstitucional, imprópria para o país, mesmo maléfica, que necessariamente havia de produzir a escravidão." Sendo assim, "e aparecendo por esta causa as comoções das províncias de São Paulo e Minas," os deputados luzias, "para o bom cumprimento dos empenhos que para com o país contraiu," teriam a obrigação de

\footnotetext{
${ }^{315}$ Ibidem. p. 366.

${ }^{316}$ Ibidem. p. 363.

${ }^{317}$ Joaquim Manuel de Macedo. Anno Biographico Brazileiro. Primeiro volume. Op. Cit. p. 82.
} 
apresentar um projeto com um único artigo: “fica revogada a reforma de 1841," provocava Ferraz - "a maioria não se devia contentar com esses melhoramentos que nada importam, com estas aparas que não trazem benefício algum, que conservam quase tudo no mesmo ou em pior estado."318 A intenção da oposição era desmascarar os planos do grupo luzia de dentro e de fora da Câmara dos Deputados. Ao exigir coerência e pedir que os defensores do projeto propusessem a revogação imediata da Lei de 03 de dezembro, os membros da patrulha conservadora visavam demonstrar a destrutividade do projeto político da facção que em 1842 pegara em armas. Na tentativa de alertar o restante da Câmara para o perigo representado por esse projeto, os oposicionistas relacionavam diretamente a opinião dos defensores da reforma com o ideário dos rebeldes: a demanda pela modificação da Reforma do Código vinha, segundo eles, da parte do povo que estivera ligada aos levantes armados contra a ordem política do Império.

O padre mineiro José Antonio Marinho, furioso com as acusações vindas da parte de D. Manoel e da bancada baiana, acabaria por dar aos inimigos da proposta a arma que eles mais desejavam.

Dizem isto porque fizemos um protesto armado contra a Lei da reforma judiciária: ainda é uma injustiça dos nobres deputados. (...) Consultem-se os documentos da época, consultem-se os fatos que então ocorreram, e convencer-se-ão de que não foi a Lei de 03 de dezembro de 1841 que pôs as armas nas mãos das pacíficas e industriosas províncias de Minas e São Paulo. (...)

Senhores, a Câmara de 1842 reuniu-se, tinha por missão emendar todas estas leis anti-constitucionais; ela foi inconstitucionalmente dissolvida. Sr. presidente, como diz o salmista, um abismo chama outro abismo. (...) Dissolvida assim a Câmara anticonstitucionalmente, erigindo-se o governo juiz das eleições (...); a imprensa perseguida; testemunhos aqueles que escreviam as folhas públicas, ou que tinham nelas alguma participação, perseguidos judiciariamente e esbordoados pelo cacete da polícia. A tribuna assim trancada, a imprensa perseguida, as câmaras municipais de minha província dirigem ao trono representações submissas sobre os males que entendiam estavam eminentes a cair sobre o país, suspensas, mandadas responsabilizar! O que quereis pois? Sem imprensa, sem tribuna, punido o direito de petição, a autoridade judiciária e policial confiada pela maior parte ao lixo da sociedade; arrancados de seus lugares magistrados honestos e honrados, a favor de quem falavam longos serviços prestados ao seu país para serem substituídos por moços inexpertos, vertiginosos, inteiramente preocupados do espírito de partido e do desejo de eternizar suas idéias. (...) A Guarda Nacional demitida desde o chefe de legião até o sargento.

(...) Eis, Senhores, as causas que trouxeram estes movimentos. Não quero discutir se por ventura era dada a última razão, se por ventura

\footnotetext{
${ }^{318}$ Anais da Câmara dos Deputados. 30 de julho de 1845. p. 363.
} 
era dado o último caso (apoiados), talvez... fosse melhor que sofrêssemos (apoiados), porque o sangue dos mártires sustenta a causa dos que sofrem o martírio; mas, entretanto, os sustos, as apreensões legítimas, as perseguições odiosas que se desenvolviam... ${ }^{319}$

O padre Marinho foi um dos mais ferozes críticos das medidas regressistas e, no ano de 1842, exerceu importante liderança no movimento armado, tendo publicado uma justificativa do levante luzia, já em 1844, sob o título de História do Movimento Político que no Anno de 1842 teve lugar na Província de Minas Geraes. ${ }^{320}$ Segundo ele, o levante não havia sido feito contra uma ou outra lei, mas sim contra os abusos levados a cabo pelo gabinete de 23 de março, o qual, na sua visão, destruíra os pilares da ordem constitucional. Cidadãos de bem, proprietários e capitalistas de São Paulo e de Minas Gerais, lutaram pelas liberdades pátrias que estavam sendo rasgadas pelos desmandos da Oligarquia. As "leis reacionárias" foram apenas instrumentos nas mãos daquele gabinete que sequer fez por bem escutar as queixas do povo brasileiro enviadas por intermédio das petições. A luta contra elas na arena parlamentar, argumentava Marinho, mais do que uma concessão aos ex-rebeldes, significava uma tentativa de se resgatar o país da lama em que os regressistas o haviam afundado. O que não calculava o deputado mineiro era que ao rememorar, diante de seus pares, as petições que antecederam a rebelião, evidenciava que as deputações de Minas e São Paulo continuavam ligadas ao ideário que motivara a luta armada: assim, dava força ao argumento de seus adversários.

A resposta de D. Manoel ao padre Marinho aparecia como um duro golpe às pretensões dos defensores do projeto de reforma da Lei de 03 de dezembro:

é inexato que o Brasil se opusesse com baionetas a esta salutar legislação... (...) Foram apenas duas províncias... não digo bem... corrijo já a expressão... foram apenas duas pequenas frações de duas províncias que ousaram levantar o estandarte da rebelião com o pretexto frívolo e fútil de que essas leis tinham abertamente violado a Constituição: mas... mas não foram estes os fins, Sr. presidente; o fim (é preciso que o diga, pois infelizmente tantas vezes nesta casa se fala destes fatos) o fim não foi, nem podia ser senão um único, subir.

Se, continuava D. Manoel, “acaso as províncias do Império se tivessem em massa, ou na sua grande maioria, oposto a esta lei salutar, então podia ainda ter algum fundamento" a opinião de que sua reforma se constituía numa necessidade. "Mas eu vi o contrário." O deputado goiano acreditava que "a maior parte das províncias do Império receberam cheias de satisfação esta lei salutar.” E continuava: “não só as províncias não

\footnotetext{
319 Anais da Câmara dos Deputados. 31 de julho de 1845. p. 387.

${ }^{320}$ José Antonio Marinho. História da Revolução de 1842. Brasília: Senado Federal, 1978.
} 
resistiram à Lei de 03 de dezembro de 1841, como aceitaram com satisfação e algumas até felicitaram o governo por essa lei." Sendo assim - concluía - caía por terra o argumento dos deputados luzias, "porque o Brasil não se cifra só em Minas Gerais e São Paulo." 321

A situação dos defensores da reforma somente piorava quando D. Manoel interpretava os discursos dos deputados mineiros e paulistas como uma tentativa de “justificar o procedimento eminentemente criminoso que tiveram na sua província alguns do seu partido." Para o deputado goiano, a tentativa de se justificar o levante de 1842, empreendida por homens como Marinho, fazia parte de um plano: "o nobre deputado, Senhores, é coerente com o seu sistema, quer já prevenir... (não sei se o nobre deputado permitirá dizê-lo)... quer já justificar de antemão uma nova rebelião que por ventura possa haver, mas que eu espero que não haja. ${ }^{322}$ Voltando os argumentos do grupo luzia contra o próprio, D. Manoel acusava-o de sedicioso e diferenciava suas demandas dos verdadeiros interesses da nação brasileira. Ficava claro que as províncias que haviam participado do levante armado em 1842 ainda carregavam, no ano de 1845 , a pecha de facciosas. Suas demandas, expressas nas dezenas de petições de câmaras municipais e nos discursos de ex-rebeldes como Marinho ou Álvares Machado, eram vistas com desconfiança pela patrulha conservadora e - pior ainda - pelas bancadas liberais de outras províncias. Por terem desafiado o princípio básico do regime representativo, que era a solução das divergências dentro da ordem institucional, depois de derrotada a rebelião e retomada a ordem, os representantes das elites paulista e mineira pagavam um elevado preço: eram taxados de facciosos pelos seus pares na Câmara.

Quando o ministro dos negócios estrangeiros Limpo de Abreu declarou que o gabinete liberal de 02 de fevereiro acreditava que a iniciativa daquela reforma tão importante deveria caber ao Poder Executivo e não à Câmara dos Deputados, a posição dos deputados luzias se mostrou ainda mais fraca. Limpo de Abreu vinha à Câmara dizer que a proposta das comissões não satisfazia a ninguém, sendo um movimento de retroação a um passado que deveria ser esquecido definitivamente, uma verdadeira precipitação dos deputados que não tinha razão alguma de ser naquela conjuntura. Ele prometia que na sessão seguinte o ministério apresentaria uma proposta de reforma completa e conveniente da Lei de 03 de dezembro; no entanto, seu posicionamento

\footnotetext{
${ }^{321}$ Anais da Câmara dos Deputados. 02 de agosto de 1845. p. 420.

${ }^{322}$ Ibidem. pp. 419-420.
} 
francamente oposto ao dos liberais de São Paulo e Minas abria um conflito com seus antigos aliados. $^{323}$

O padre Marinho se opôs à posição protelatória do ministro, pois acreditava na "urgente necessidade de satisfazer aos empenhos contraídos com os meus comprovincianos (...) na ocasião que recebi o seu mandato." E continuava com uma provocação ao também deputado mineiro Limpo de Abreu:

declaro, Senhores, que nenhum de nós que nos achamos aqui sentados como deputados por Minas, viríamos a esta casa pelo voto livre e espontâneo dos eleitores mineiros se eles não contassem que nós trataríamos da revogação dessa lei que tem sido um flagelo para aquela província, como para todas as do Império. Tenho pois de satisfazer a esse solene compromisso que contraí com aqueles que me honraram com os seus sufrágios. ${ }^{324}$

Indignados com a posição de seu antigo aliado, os deputados luzias cobravamlhe coerência, que agisse em consonância com as expectativas de seus eleitores. Álvares Machado se contrapunha ao ministro ao dizer que "a Constituição confere o direito de iniciar leis tanto ao governo, como a cada uma das Câmaras [Câmara dos Deputados e Senado] do Poder Legislativo" e, se houvesse na letra da lei preferência a um dos ramos do Estado para iniciar reformas, esta prioridade seria dada "sem dúvida à Câmara dos Srs. Deputados." 325 Eram os deputados os representantes da nação, eram eles que haviam recebido dezenas de petições demandando a reforma. Assim como Marinho, Álvares Machado apelava para o passado de Limpo de Abreu:

se os compromissos existem, é o nobre ministro um dos mais envolvidos nele, e está na rigorosa obrigação de o satisfazer; esses compromissos não consistem em meras promessas, mas no dever de abolir, e de abolir quanto antes, essas leis que o nobre ministro reconhece que ofendem a Constituição em muitas de suas teses e motivou uma resistência armada em duas províncias. ${ }^{326}$

O agora ministro havia se envolvido diretamente na rebelião de 1842 , tendo sido por isso preso e deportado para Portugal; no entanto, aos olhos dos seus ex-aliados, parecia abandonar em 1845 a causa pela qual pagara com a própria liberdade. Aflitos com a evidente falta de apoio de todas as partes, os defensores da reforma entravam em contradição ao exigir o compromisso do líder mineiro com a causa rebelde. O conflito aberto entre a bancada luzia e Limpo de Abreu dava ainda mais força aos opositores da

\footnotetext{
${ }^{323}$ Anais da Câmara dos Deputados. 04 de agosto de 1845. pp. 430-437.

${ }^{324}$ Anais da Câmara dos Deputados. 31 de julho de 1845. p. 385.

${ }^{325}$ Anais da Câmara dos Deputados. 04 de agosto de 1845. p. 431.

${ }^{326}$ Ibidem. p. 433.
} 
reforma e o deputado conservador da província do Piauí, José Idelfonso de Souza Ramos, aproveitava a ocasião para atacar a posição dos ex-rebeldes:

um nobre deputado pela província de São Paulo [Álvares Machado], para provar que esta lei necessitava de pronta reforma, por ter contra si a opinião pública, trouxe-nos à lembrança as duas rebeliões acontecidas nas províncias de Minas e São Paulo.

$\mathrm{O}$ argumento, Sr. presidente, não tem força alguma, porque rebeliões apareceram contra a Lei de 03 de dezembro de 1841, não se segue que tenha contra si a opinião pública, que seja inconveniente e deva ser reformada, pois que o simples bom senso reconhece a sem razão com que por este pretexto se lançou mão das armas. (...) Pois homens que não têm as luzes dos legisladores poderiam declarar essa lei como inconstitucional, como viciosa, no campo com as armas na mão? Pois as discussões das baionetas e do fuzil têm em seu favor mais força de razão que as do raciocínio?

(...) A razão de terem aparecido essas rebeliões com o pretexto de emendar-se os defeitos da Lei de 1841, na minha opinião, apenas serve para mostrar a necessidade que há de haver uma discussão a este respeito, para que aqueles que se iludiram acreditando que esta lei viola a Constituição do Estado se desenganem vendo que os partidaristas da mesma opinião a não puderam sustentar na discussão. (Apoiados.) Depois da opinião que o nobre ministro de estrangeiros emitiu a respeito do projeto de reforma apresentado pelas nobres comissões, me parece que o país, que com razão tem em muita conta as luzes e as boas intenções do nobre ministro, ficará persuadido de que conquanto esta lei necessite de ser revista, conquanto não seja obra em tudo perfeita, contudo pode muito bem reger o país sem aparecerem os inconvenientes que o ilustre deputado por São Paulo há poucos dias indicou, quando disse: - não ponhamos o povo que não aceita esta lei, e que é por ela oprimido, na necessidade de lançar mão das armas - o país há de se convencer, quando convencido já não estivesse, de que esta necessidade não existe. (Apoiados.) ${ }^{327}$

A desunião no seio do grupo luzia, reforçava o argumento contra a necessidade da reforma judiciária. $\mathrm{O}$ debate parlamentar mostrava que lhes faltava força política e, para piorar, o ministério se recusava a apoiar a medida proposta. Os representantes das elites políticas de Minas e São Paulo não chegaram a um acordo com as lideranças ministeriais que, supostamente, deveriam lhes apoiar. Um ex-aliado do movimento rebelde, Limpo de Abreu, aderia aos princípios moderados e pragmáticos do ministério de 02 de fevereiro e deixava seus comprovincianos desamparados na luta pela reforma.

A crítica final, naquele ano de 1845, às pretensões dos adversários da Lei de 1841 não poderia ter saído da boca de outro deputado que não D. Manoel. Aproveitando-se do conflito instaurado pelas declarações de Limpo de Abreu, ele atacava o ideário dos liberais mineiros e paulistas.

${ }^{327}$ Anais da Câmara dos Deputados. 06 de agosto de 1845. pp. 474-475. 
Não é dos delegados e subdelegados que vem o mal do país, é de uma causa que eu tantas vezes tenho apontado nesta casa, é do estado da nossa desmoralização. Confesso a verdade que não tenho esperança nenhuma de conseguir reforma; é a mesma coisa, continuamos na mesma. Era necessário principiar por moralizar o país, educando o povo. Não é da lei da reforma que nasceram as desordens nas províncias. Algum espírito menos atento talvez o acredite; mas quem pensa não o pode entender assim. Eu não vejo na lei estes inconvenientes e confesso que me pareceram muito superiores aos que na prática tenho enxergado. ${ }^{328}$

Não teriam sido os supostos vícios da Lei de 03 de dezembro de 1841 a causa da rebelião de paulistas e mineiros, mas sim os princípios anárquicos que guiavam a facção liberal destas províncias. Por estes mesmos princípios buscavam eles, naquele ano de 1845, reformar o Judiciário e reinstaurar no país a temível democracia que no tempo da Regência causara tantos estragos. Segundo o deputado goiano, a opinião expressa nos manifestos dos rebeldes, nas petições de 1842 e 1845 e nas falas de Álvares Machado e do padre Marinho representava um grande risco para a ordem e para a estabilidade da monarquia constitucional. D. Manoel demonstrava contentamento ao expor sua tese de que a facção luzia, de tão desordeira, sequer podia chegar a um acordo quanto ao projeto apresentado pelas comissões.

Sem o apoio de seus pares de outras províncias ou mesmo do ministério liberal sobre o qual haviam colocado suas esperanças, os deputados paulistas e mineiros, de mau grado, engoliram a aprovação de um adiamento. O deputado Gabriel José Rodrigues dos Santos, no entanto, afirmava que a maioria da Câmara estava fazendo um sacrifício e esperava atenta pela iniciativa do ministério. Complementava sua afirmação em tom de ameaça:

não se pense que a maioria faz sacrifícios de princípios. Se o Sr. ministro não declarasse que é fiel aos seus princípios sustentados, quer na tribuna, quer no ministério, quer como membro da maioria, quer da oposição, se não declarasse muito solenemente que reconhecia os defeitos da Lei de 03 de dezembro de 1841, se o Sr. ministro dissesse que rejeitava toda a reforma, e que julgava essa lei boa, desde esse momento o repudiaríamos, nós o guerrearíamos com todas as nossas forças. (Apoiados.) $)^{329}$

Rodrigues do Santos, paulistano de nascimento, foi professor do curso de direito em São Paulo e exerceu o cargo de vereador na mesma cidade. Promotor público e juiz de direito na capital paulista no início da carreira, foi eleito algumas vezes para a Assembléia Provincial e chegou a exercer, sob a presidência de Rafael Tobias de

${ }^{328}$ Ibidem. p. 483.

${ }^{329}$ Anais da Câmara dos Deputados. 04 de agosto de 1845. pp. 442-443. 
Aguiar, o cargo de secretário geral da província. Com o mesmo Tobias de Aguiar fundou em 1842, pouco antes do levante armado, a folha radical $O$ Tebyreçá que atacava frontalmente a política do Regresso. Segundo relata o biógrafo da elite imperial, Sébastien Auguste Sisson, Rodrigues dos Santos

acompanhou seus amigos com fidelidade e coragem na desgraçada revolução de 1842; sofreu o destino reservado aos vencidos, apresentou-se ao tribunal do povo para ser julgado, e foi absolvido, porque o povo não sabe condenar a consciência pura e o mártir da liberdade, que ainda que iludido estivesse, ou exagerado fosse, não lhe passava pelo espírito senão o pensamento de vingar a lei fundamental ofendida. ${ }^{330}$

A descrição que outro biógrafo, Sacramento Blake, faz de Rodrigues dos Santos é próxima à de Sisson: "suas idéias de exaltado liberalismo o levaram a comprometer-se na revolução de 1842." ${ }^{\text {331 }}$ Fácil compreender, a partir da figuração do deputado paulista como um ideólogo exaltado, o seu descontentamento com o recuo do ex-aliado Limpo de Abreu em relação à reforma da Lei de 03 de dezembro.

Adiado o projeto de reforma judiciária, o ano de 1846 principiou com uma boa notícia para os inimigos da Lei de 03 de dezembro. O deputado mineiro Fernandes Torres, presidente da Câmara no ano de 1845, se tornou ministro da justiça e Limpo de Abreu ficou fora do novo ministério liberal. No dia 10 de julho de 1846, Fernandes Torres apresentou um novo projeto de reforma judiciária sob o argumento de que acreditava ser necessário corrigir incoerências, lacunas e defeitos da Lei de 1841. Havia na nova proposta, segundo o ministro, uma tentativa de se fazer a reforma judiciária conciliando interesses que, no ano anterior, haviam se contrastado; Fernandes Torres buscava o apoio dentro da Câmara que faltara ao projeto das comissões. Dentre as principais medidas do projeto do ministro estavam: $1^{\text {a }}$ ) a retirada da atribuição de formação de culpa dos delegados e subdelegados, com exceção dos "crimes de rebelião, sedição ou outros graves"; $2^{a}$ ) a passagem da atribuição de formação de culpa para o juiz municipal e, na sua ausência, ao juiz de paz; $3^{\mathrm{a}}$ ) a organização dos processos crimes pelos juízes de paz; $4^{\mathrm{a}}$ ) a manutenção da nomeação dos juízes municipais (e de seus cinco suplentes) exclusivamente pelo poder central; $5^{\mathrm{a}}$ ) a formulação da lista de jurados por uma junta formada pelo juiz de paz, pelo pároco e pelo eleitor mais votado da localidade; $6^{a}$ ) a revisão da mesma lista por uma junta municipal composta pelo juiz de

\footnotetext{
${ }^{330}$ Sébastien Auguste Sisson. Galeria dos Brasileiros Ilustres. Volume I. Brasília: Senado Federal, 1999. p. 220.

${ }^{331}$ Augusto Victorino Alves Sacramento Blake. Op. Cit. Terceiro volume. p. 167.
} 
direito e pelos dois vereadores mais votados; $7^{\mathrm{a}}$ ) a limitação a uma apelação apenas à decisão do júri; $8^{\text {a }}$ ) o Artigo 34, que previa a aposentadoria compulsória para os membros do Poder Judiciário que fossem eleitos deputados gerais ou senadores (sem receber ordenado se tivessem servido por menos de dez anos; recebendo apenas um terço caso tivessem servido por mais de dez; recebendo metade caso tivessem servido por mais de vinte; e com todo ordenado se tivessem servido por mais de trinta anos). ${ }^{332}$

Ao moderar as medidas propostas pelo projeto das comissões, Fernandes Torres não deixara de atacar a influência do poder central sobre a administração da justiça. Justificou-se o ministro em relação ao Artigo 34: "é muito difícil, senão impossível, conciliar a qualidade de legislador com a de juiz, sem que a administração da justiça se ressinta da falta de permanência de seus magistrados em seus respectivos lugares; e a experiência tem mais que muito comprovado entre nós esta verdade." ${ }^{333}$ Os liberais mineiros e paulistas, a partir da volta de quadros de seu partido ao Executivo em 1844 e com a eleição de ex-rebeldes para a Câmara, empreenderam um grande esforço para combater a influência - que acreditavam ser maléfica - de magistrados e funcionários públicos sobre o Poder Legislativo: tanto a cláusula das inelegibilidades do projeto de reforma eleitoral apresentado em 1845 (ver capítulo 3), quanto a aposentadoria compulsória do projeto de Fernandes Torres fizeram parte deste esforço. Ao abrirem mão de algumas de suas propostas em defesa das autoridades locais, os luzias passaram a atacar os magistrados que eram desde 1841, em sua maioria, indicados pelo centro; o que eles não calcularam, contudo, era que aí estava seu calcanhar de Aquiles.

D. Manoel foi o primeiro deputado a se inscrever no debate acerca do projeto do ministério. Segundo ele, de qualquer ponto que se olhasse, o projeto ministerial era um desastre; sobretudo o Artigo 34 representava uma verdadeira aberração, pois impedia que os honrados magistrados brasileiros compusessem a representação nacional. Só um fato poderia explicar a atitude de Fernandes Torres: a sofreguidão com que as lideranças políticas brasileiras tomavam o caminho das reformas. Fato este que trazia graves conseqüências ao país, pois "a facilidade e precipitação em legislar" habituavam "o povo a ter pouco respeito à legislação do país, que todos os dias se muda e altera" e geravam "menos confiança nas pessoas encarregadas de confeccionar as leis," acabando por "entibiar o zelo das autoridades incumbidas de executá-las." 334 A proposta, segundo

\footnotetext{
${ }^{332}$ Anais da Câmara dos Deputados. 10 de julho de 1846. pp. 125-128.

${ }^{333}$ Ibidem. 126.

${ }^{334}$ Anais da Câmara dos Deputados. 03 de agosto de 1846. p. 398.
} 
o deputado goiano, deveria ter passado pelo Conselho de Estado antes de ser apresentada à Câmara. O projeto era ruim e somente a reflexão calma e pausada poderia ajudá-lo a se adequar às necessidades do país. A compulsão reformista dos liberais principalmente de sua facção luzia - era a causa maior das desordens que haviam assolado o país desde a Abdicação. $\mathrm{O}$ ataque frontal, porém, ficava reservado para a segunda parte do discurso de D. Manoel:

o partido que hoje ocupa as posições sociais, e por conseqüência influi no país, exigia a revogação de algumas leis, e entre elas a de 03 de dezembro de 1841; assim se disse nesta casa por diferentes vezes, e é fato que não se pode contestar. $\mathrm{O}$ governo, e mais especialmente $\mathrm{o}$ nobre ministro da justiça, que não se pode duvidar pertence a esse partido, tinha de cumprir a promessa que havia feito.

(...) Esta minha proposição a ninguém devia espantar, porque na casa os órgãos desse partido uma e muitas vezes repetiram que tinham prometido solenemente trabalhar com todo o seu afinco para a revogação de algumas leis, as quais foram, segundo eles, uma das causas das rebeliões de Minas e São Paulo. Ora, considerando o Sr. ministro como ligado a esse partido, supondo eu que ele tinha seu compromisso, não admira que eu considerasse a proposta como cumprimento dessa promessa. E, Senhores, se eu leio com atenção a proposta, devo convencer-me de que, com efeito, é cumprimento de promessa. ${ }^{335}$

D. Manoel constatava que em 1846, diferentemente do que acontecera em relação a Limpo de Abreu no ano anterior, os ex-rebeldes haviam encontrado um aliado dentro do ministério: Fernandes Torres estaria incumbido de elevar o ideário luzia ao posto de guia da política nacional. Sendo assim, ao subir ao Executivo, a facção que lançara "mão das armas" vinha agora exigir da Câmara que seu projeto fosse cumprido. ${ }^{336}$ Perante um projeto de lei tão ruim, o deputado goiano atacava o ministro da justiça por ter se entregue às vontades mesquinhas de um grupo que agia em prol de um interesse sórdido:

só digo que admiro a coragem do Sr. ministro, e muito mais a admirei quando vi que um ministério, em uma proposta que trata de reformar o sistema judiciário, consignasse uma idéia tão anti-constitucional como a que já tinha sido apresentada no corpo legislativo; idéia só filha de uma facção, idéia enfim que parte de um plano premeditado de aluir os alicerces do governo monárquico. ${ }^{337}$

Concordando com D. Manoel, o deputado paraibano França Leite dizia que o projeto, devido às suas falhas, seria fatal para o Brasil:

\footnotetext{
${ }^{335}$ Ibidem. p. 400

${ }^{336}$ Ibidem. p. 400.

${ }^{337}$ Ibidem. p. 401.
} 
o país, experimentado por uma dolorosa experiência dos males que pesam sobre ele atualmente, achando que não encontra na medida que atualmente se toma os bens que ele deseja... Eu não receio falar à Câmara; com toda franqueza, eu direi à Câmara, ele desesperará sobre as instituições atuais; novas opiniões aparecerão, e elas procurarão um remédio que na atualidade não poderão encontrar; e este remédio dará em resultado o combate de duas opiniões que se dilacerarão, a democracia pura ou a monarquia absoluta. ${ }^{338}$

França Leite era um liberal que, em 1842, chegou a participar do levante junto de seus colegas de Minas e São Paulo e acabou exilado em Portugal; ${ }^{339}$ contudo, a exemplo de Limpo de Abreu, havia se distanciado dos luzias no que se referia à questão judiciária por enxergar sua proposta como um exagero injustificado que, depois do conflito armado, só traria males ao país. Líder da bancada paraibana e aliado da situação liberal em diversos outros assuntos, este deputado ajudava a comprovar a tese dos principais opositores do projeto de que Fernandes Torres fazia uma concessão aos interesses da facção luzia, criando um problema maior do que aquele que visava remediar. Um projeto com tantos defeitos, partindo de uma doutrina anticonstitucional e democrática, feito para saciar a vontade de ex-rebeldes, caso aprovado, só poderia trazer o caos ao Império. Assim como a patrulha conservadora, o liberal França Leite pintava os deputados paulistas e mineiros como um grupo disposto a provocar a reação e acabar com o equilíbrio entre ordem e liberdade que sustentava o regime constitucional brasileiro. Pior ainda, imputava aos defensores do projeto a pecha de facciosismo, ou seja, de quererem impor ao Brasil uma vontade idiossincrática a qual, ao fim e ao cabo, levaria à ruptura da união nacional.

Uma valiosa ajuda que receberam os inimigos da proposta, no ano de 1846 , veio de ninguém menos do que de um dos principais líderes do nascente partido conservador, Paulino José Soares de Sousa, que havia sido ministro da justiça do gabinete de 23 de março e principal idealizador da Lei de 03 de dezembro de 1841. Eleito em 1844 deputado suplente pelo Rio de Janeiro, Paulino assumia em 1846 dizendo em seu discurso que a lei, em si, não era má; mas as "violações próprias de tempos calamitosos", sim, eram as verdadeiras causas dos abusos apontados pela bancada luzia. "Não culpemos, portanto, a Lei de 03 de dezembro, e apelemos para melhores tempos" - continuava o ideólogo do Regresso - "quando o governo tiver justiça e moralidade, quando não for cúmplice de tais violações, ou quando o medo o não fizer recuar diante

\footnotetext{
${ }^{338}$ Anais da Câmara dos Deputados. 04 de agosto de 1846. p. 413.

${ }^{339}$ Joaquim Manuel de Macedo. Anno Biographico Brazileiro. Segundo volume. Op. Cit. p. 288.
} 
de certos homens reputados poderosos, as leis hão de recuperar seu império." ${ }^{340}$ A culpa pelas turbulências políticas pelas quais o país passara nas últimas décadas não seria da legislação regressista, mas sim da falha em seu cumprimento. Perspicaz, Paulino insinuava que eram as lideranças facciosas de Minas e São Paulo as verdadeiras responsáveis pelo estado calamitoso no qual o país se encontrava. A mesma idéia foi repetida logo em seguida por Junqueira: segundo ele, os males da nação eram fruto de “circunstâncias excepcionais, circunstâncias que provêm de um estado de reação, resultado de revolução, de comoções. Nestas circunstâncias não há lei alguma por mais bem feita que seja que possa ter bom resultado."341

A estratégia adotada pela patrulha conservadora era esvaziar a demanda de paulistas e mineiros colocando a culpa dos problemas que eles combatiam sobre suas próprias atitudes de rebeldia contra as autoridades nacionais. Neste sentido, o deputado fluminense Josino Nascimento da Silva dizia que a maior desgraça dos brasileiros era que

o legislador se tem persuadido que a sua vontade é livre, que ela não reconhece limites ao seu poder, e que tem faculdade discricionária de legislar em todos os casos da forma mesma que lhe aprouver. Oh! Que falta de inteligência! Oh! Que princípios perniciosos! Assim eles acabarão por desarraigar do povo o respeito e veneração que ele tributa às leis, assim o ensinarão a violar as leis, assim a perturbar a ordem pública e a estabelecer o perigoso princípio de que é lícito recusar obediência às leis, quando sua observância trouxer consigo a privação de algum direito; e então com que direito se possa lançar em rosto ao povo a subtração de sua obediência às leis do país, se o exemplo fatal parte do seio dos legisladores? Ah! Sr. presidente, não convém que meditemos em tão fatais conseqüências: nos sirvam de lição os exemplos de outras nações. ${ }^{342}$

Aqueles que estavam no poder deveriam, segundo este ponto de vista, dar exemplo de respeito às leis e não fazer concessões a facções belicosas. Mais uma vez os males do país eram atribuídos às ações daqueles que, num dado momento, se levantaram contra as "leis reacionárias" em São Paulo e Minas Gerais. Como comprovação de sua teoria, os inimigos da proposta dispunham do fato de que aqueles que demandavam a reforma judiciária eram exatamente os mesmos que haviam comandado a desobediência e provocado a guerra civil.

\footnotetext{
${ }^{340}$ Anais da Câmara dos Deputados. 05 de agosto de 1846. p. 436.

${ }^{341}$ Ibidem. p. 436.

${ }^{342}$ Anais da Câmara dos Deputados. 08 de agosto de 1846. p. 465.
} 
O “chefe da patrulha", Ângelo Muniz da Silva Ferraz, foi responsável por apresentar à Câmara a prova definitiva de que a proposta agora abraçada pelo ministro da justiça era, na verdade, uma concessão aos ex-rebeldes.

Tenho uma representação do meu nobre colega, o Sr. Pinto Coelho, como presidente [de Minas Gerais] durante a revolução, dirigida e assinada entre outros, pelos Srs. Marinho, Ottoni e outros meus nobres colegas desta casa. Nesta representação se consignaram os motivos da rebelião e os seus autores assim se exprimiam: - "Os deputados à Assembléia Legislativa de Minas Gerais, reunidos em sessão preparatória nesta cidade, faltariam a si e à briosa província que os elegeu, se nesta ocasião solene em que os mineiros se erguem para repelir dos seus pulsos as algemas do absolutismo, deixassem de manifestar perante V. Ex. os sentimentos de que se acham possuídos... Como órgãos pois de nossos constituintes, não hesitamos em afiançar a V. Ex. nossa adesão franca e decidida ao movimento do dia 10 de julho: é conhecida a opinião dos deputados efetivos, que são constrangidos a não comparecer na presente sessão extraordinária, e sem dúvida que todos acompanhariam unânimes tais abaixo assinados, para agradecer a V. Ex. a resolução heróica que tomou a 10 de julho, $e$ oferecer ao governo interino a coadjuvação do seu voto, sua pessoa e bens para levar-se a efeito a restauração da Constituição do Império rasgada por essa lei de sangue que a facção absolutista se atreveu promulgar."

Eis pois o fim da rebelião: eis pois o compromisso solene de revogar a Lei de 03 de dezembro de 1841.

(...) Assim também o entendia a Assembléia Provincial de São Paulo, e pediu à Coroa em uma representação a suspensão da execução da mesma lei. ${ }^{343}$

Apareciam, enfim, no discurso de um conservador as petições de paulistas e mineiros. Neste caso, Ferraz se referia a petições enviadas em 1846 pelas Assembléias Legislativas de Minas Gerais e de São Paulo, uma em apoio ao projeto de reforma judiciária apresentado no dia 10 de julho por Fernandes Torres e outra solicitando a suspensão da execução da Lei de 1841 em seu território. Estavam nelas a justificativa das propostas do ministro da justiça e assinavam-nas ex-rebeldes que, durante a situação liberal, ocupavam assentos na Câmara dos Deputados e defendiam a revisão da Lei de 03 de dezembro. Petições com idéias próximas àquelas haviam sido enviadas à Câmara em 1842 e em 1845. Quando Ferraz trazia à lembrança de seus pares tais documentos, provocava a assimilação entre a proposta do ministério e a demanda das elites políticas rebeldes de Minas e São Paulo. Os mesmos homens que em 1842 haviam pegado em armas, dominavam em 1846 o programa político - ao menos no campo da reforma judiciária - dos ocupantes do Poder Executivo. E, fato mais grave segundo o deputado baiano, utilizavam da lembrança da rebelião para justificar seu projeto:

${ }^{343}$ Anais da Câmara dos Deputados. 13 de agosto de 1846. pp. 526-527. 
a história de todos os movimentos revolucionários nos deve ser mais conhecida quando queremos debelar aqueles que julgamos infensos às nossas opiniões, ao nosso sistema e aos nossos interesses; exageramos as acusações a ponto tal, que nada esquecemos que possa descrever com negras cores as intenções, o sistema dos nossos adversários. Passado porém o momento do combate, pacificado o país, as opiniões se modificarão. As opiniões exageradas se devem convencer de que só há precisão delas no momento da peleja; terminada esta, ou devem modificar-se, ou serão desprezadas. (...) Devemos porém sobretudo lastimar as vítimas que fazemos por amor de nossas opiniões exageradas: as vítimas, de ordinário, são os que nos seguem e nos apóiam, são aqueles que chamamos para o campo do combate, aqueles a quem armamos; os chefes vão sempre bem; quando muito têm a coroa do martírio e depois reabilitação gloriosa, e afinal o poder com todas as suas vantagens.

Este pensamento aqui deixo somente para mostrar a necessidade que há de abandonarmos o princípio de resistência armada. ${ }^{344}$

Ao trazerem sempre à lembrança os acontecimentos de $1842 \mathrm{e}$, sobretudo, ao se utilizarem do mesmo discurso dos rebeldes, os defensores do projeto transformavam a tribuna parlamentar numa continuação do campo de guerra. Ao insistirem no tema da rebelião, afirmava o "chefe da patrulha", os derrotados de 1842 apenas demonstravam que não estavam preparados para o sistema constitucional, para a negociação legítima no seio da representação nacional; mas, antes, que eram chefes facciosos e oportunistas que se aproveitavam do sangue das vítimas do conflito para impor seus caprichos a todo o país.

Baseado nas representações citadas por seu colega Ferraz, o piauiense Souza Ramos dizia que, ao propor aquela reforma, o grupo luzia - incluso, principalmente, Fernandes Torres - subvertia a ordem que deveria governar uma nação civilizada. Segundo ele, a apresentação dos documentos fora útil "para que fique patente aos olhos de todos que não tem fundamento razoável o juízo do nobre ministro da justiça, quando inculcou que a sua proposta era reclamada pelas necessidades do país." Fernandes Torres deveria "aprender a desconfiar de semelhantes reclamações," pois, "quando duas províncias saltam por cima da Constituição, põem em perigo a monarquia (apoiados) e se abalançam a sujeitar-se a todos os incômodos, a ensangüentar o seu país, para conseguir a reforma de uma lei," o poder de Estado não poderia jamais referendar sua vontade. Isto seria deturpar o espírito do regime e não compreender que "a experiência esclarecida" deveria "guiar o governo nesta questão e não as explosões de paixões, das

\footnotetext{
${ }^{344}$ Anais da Câmara dos Deputados. 13 de agosto de 1846. p. 527.
} 
ambições desregradas..."345 O projeto de lei significava uma concessão a extremistas e desordeiros, àqueles que não souberam aceitar a legislação elaborada pelos representantes da nação e lançaram mão de armas. Fernandes Torres, segundo a patrulha conservadora, caía num erro sem justificativa quando fazia as vontades daquela facção que ainda vivia dos ódios de 1842. A oposição apontava o dedo às intenções dos defensores da proposta dizendo que o projeto não era idéia abraçada pelo país, mas sim idéia de uma facção.

Frente a uma acusação tão grave, os defensores do projeto não ficaram calados. O ministro da justiça foi o primeiro a responder aos ataques dos regressistas:

um governo que apresentasse à Câmara uma proposta de lei para modificar a legislação que julga defeituosa só tivesse em vista promessas e concessões, era indigno da confiança da Coroa e das Câmaras (muitos apoiados e muitos não apoiados), se só tivesse em vista promessas e concessões sem ter em vista os interesses públicos. (Apoiados gerais.) (...) O governo quando tratou de apresentar a proposta à Câmara, modificando a Lei de 03 de dezembro na parte que julgava defeituosa, lei que não julgou defeituosa por si só, mas que assim tem sido julgada em parte de suas disposições pela maioria do país, teve em vista o interesse público. Muito natural é que satisfizesse àqueles que acompanham a sua opinião; mas o gabinete tem dito mais de uma vez na tribuna que não tem partido, que tem uma opinião e que abraçará todos aqueles que quiserem apoiar essa opinião. Portanto, torno a repetir, que o governo seria indigno da confiança da Coroa, da Câmara e do país se tivesse em vista satisfazer promessas, e muito menos fazer concessões. ${ }^{346}$

O ministro da justiça buscava argumentar que a proposta satisfazia ao interesse do país como um todo e não ao de uma facção. Como representação nacional, a Câmara dos Deputados deveria repelir qualquer ato que não beneficiasse todas as partes do Império. Em apoio ao ministro, Rodrigues dos Santos dizia que as eleições de 1844 haviam inaugurado uma nova política, uma política de paz e conciliação, porém, os interesses reacionários, por estarem incapacitados para o franco debate, utilizavam-se dos ardis mais abjetos para impedir a necessária mudança. Sendo assim, os defensores da proposta deveriam fortalecer suas convicções e demonstrar "sincero esforço para o triunfo das idéias que têm merecido o assenso do país e que devem ser sustentadas e defendidas pelos gabinetes de um regime representativo." O país - continuava o deputado luzia - "tem altamente reclamado contra a falta de justiça e solicitado as modificações mais urgentes de nossa legislação judiciária." Pela maneira por que se

\footnotetext{
345 Anais da Câmara dos Deputados. 14 de agosto de 1846. pp. 543-544.

${ }^{346}$ Anais da Câmara dos Deputados. 04 de agosto de 1846. p. 408.
} 
encontrava organizado o Poder Judiciário, asseverava Rodrigues dos Santos, "nunca o país há de ter paz, nunca poderá marchar desassombrado pela estrada da civilização, porque todo o povo que não tem justiça nunca pode fazer progresso." Por fim, o deputado paulista dava a resposta àqueles que acreditavam que o estado anárquico da nação se devia aos abusos de paulistas e mineiros:

embora se atribuam às dissensões políticas ou à desmoralização todos
os fatos escandalosos que todos os dias estão a vista e nos aterram e
contristam, eu entendo que a causa de todos os escândalos, de todos
esses atentados, não existe na desmoralização do povo, mas sim na
falta de justiça. Por que se cometem assassinatos tão horrorosos todos
os dias? Será porque não têm as autoridades força bastante para os
punir ou porque a lei não habilita as autoridades com meios
suficientes para prover a segurança do país com a força necessária
para mantê-la? Não: é porque o Poder Judiciário está organizado
viciosamente e não assenta nas bases que a Constituição lhe
marcou. ${ }^{347}$

Rodrigues dos Santos visava inverter os argumentos da oposição: seria interesse de toda a sociedade brasileira a mudança da organização judiciária. Não fazia sentido acusar os rebeldes de provocarem o descumprimento da lei já que os movimentos sediciosos apenas haviam ocorrido devido aos abusos perpetrados contra a Constituição: não era a luta por justiça a responsável pelas revoltas, mas as medidas odiosas que deturpavam o espírito do regime, como a Lei de 03 de dezembro de 1841 . O povo brasileiro, ao eleger uma maioria liberal em 1844, lhe entregara a responsabilidade de reformar o sistema judiciário; por isso, os deputados de Minas e São Paulo obravam junto de Fernandes Torres pela aprovação do projeto que beneficiaria toda a nação.

Apesar das tentativas de reconciliar o projeto de reforma com o interesse de toda a nação, a lembrança do movimento 1842 era sempre trazida à tona pela patrulha. Alguns defensores da proposta, indignados pelas provocações de homens como D. Manoel ou Ferraz, faziam seu jogo. João da Silva Carrão, deputado paulista, foi um dos que caíram na armadilha dos defensores do Regresso. Dizia ele que, para se compreender a imperiosa necessidade da reforma,

bastava ver, como disse o deputado por Goiás, que duas províncias importantes se rebelaram por causa dessa lei: sobre o que urge ponderar que não foi unicamente por isso que apareceu a rebelião; é preciso que examinemos as circunstâncias do tempo; esta rebelião apareceu porque o partido que estava fora do poder e de todas as posições oficiais via que os recursos constitucionais iam desaparecendo; e assim, privado dos meios de satisfazer as necessidades legítimas do país, segundo suas idéias, lançou mão das

${ }^{347}$ Anais da Câmara dos Deputados. 17 de agosto de 1846. p. 557. 
armas; foi contra a política que estava então no poder que o partido se rebelou para neutralizar suas perigosas tendências. ${ }^{348}$

Nas circunstâncias em que se achava o debate parlamentar em 1846, de nada adiantava ponderar sobre os motivos que levaram as duas províncias a se levantarem contra o gabinete de 23 de março: ao darem suas explicações, defendendo os rebeldes, os deputados paulistas e mineiros faziam com que o plano da patrulha conservadora funcionasse. Às vistas da maioria da Câmara, discursos como o de Carrão simplesmente serviam para comprovar a ligação entre o levante de 1842 e a proposta de reforma judiciária. Para quem quisesse procurar melhor, as petições enviadas pelas câmaras e Assembléias de Minas e São Paulo eram uma prova cabal de que os mesmos órgãos que haviam lutado com armas contra as "leis reacionárias" apostavam agora nos seus representantes eleitos. Por mais que Fernandes Torres e alguns de seus aliados tivessem se esforçado para demonstrar que o projeto de reforma da Lei de 03 de dezembro era interesse de todo o Brasil, ficara patente que tal demanda emanara de grupos muito próximos aos rebeldes luzias.

A fraqueza da posição luzia dentro da Câmara ficou patente, sobretudo, no discurso dos liberais pernambucanos que, até aquele momento, haviam se mantido em silêncio diante do embate. Em uma das oportunidades em que D. Manoel investia contra a proposta, demonstrando as dificuldades de sua aprovação dentro da Câmara, um deputado luzia deu o seguinte aparte: "a culpa tiveram os praieiros." ${ }^{349}$ Os praieiros, em nível nacional, eram aliados da situação liberal; entretanto, em 1846, o debate acerca da reforma judiciária os afastara do ministro da justiça e dos deputados luzias. Manoel Mendes da Cunha Azevedo, autor de um estudo sobre o Código de Processo Criminal brasileiro, foi o primeiro deputado pernambucano a deixar claro que seus comprovincianos não concordavam com o teor da proposta do gabinete. Segundo ele, o projeto não satisfazia à nação, pois não conseguia verdadeiramente conciliar interesses opostos:

não ouvimos o nobre deputado por Minas Gerais [Fernandes Torres] dizer que esta era uma proposta para acomodar todos os partidos?

$\mathrm{Eu}$, então, lembrei-me da moeda em que Napoleão mandava gravar a efígie da república para acalmar a irritação dos regicidas contra o seu mais pronunciado despotismo: é verdade que sendo assim podia vir a ser uma lei contraditória aos interesses da nação; porque, incontestavelmente, uma lei de concessão a partidos, cujas doutrinas

\footnotetext{
348 Anais da Câmara dos Deputados. 07 de agosto de 1846. pp. 448-449.

${ }^{349}$ Anais da Câmara dos Deputados. 19 de agosto de 1846. p. 586.
} 
são contrárias, deve ser contraditória em suas disposições, segundo a natureza do quinhão que a cada um deles tocasse. ${ }^{350}$

Segundo cunha Azevedo, a reforma judiciária deveria se pautar sobre estudos cuidadosos acerca da situação da justiça criminal no país. A racionalidade dos representantes da nação - e não as demandas dos partidos - deveria fundamentar a revisão da Lei de 1841.

Os pernambucanos, ao apontarem as contradições do projeto de lei, deixavam evidente que a proposta do governo causava descontentamento naquela importante bancada nortista. Sobretudo, havia um elemento que afastava os praieiros do projeto de Fernandes Torres: um de seus mais importantes líderes explicava que, "infelizmente, na deputação de Pernambuco existem alguns magistrados e eis aqui o motivo de toda a desconfiança: - hão de ser por força contra a proposta, porque a proposta inclui o Artigo 34." ${ }^{351}$ Sabino, destacado líder praieiro e aliado de representantes luzias em outros projetos (como o de reforma eleitoral), indicava a principal fonte de descontentamento de seus comprovincianos em relação à proposta: o artigo que automaticamente aposentava os magistrados eleitos para o Legislativo em nível nacional. Ou seja, aos inimigos do projeto de reforma judiciária, somaram-se os descontentes magistrados do norte. Elemento central no ideário luzia, a luta contra a influência do magistrados sobre o Legislativo levava seus aliados de Pernambuco a abandonarem as fileiras governistas. O mineiro Fernandes Torres, ao buscar contentar os liberais paulistas e mineiros, provocara a dissensão dos praieiros.

D. Manoel já havia lembrado a Fernandes Torres que "não basta que um ministro da Coroa, em um governo constitucional, tenha uma opinião conscienciosa para oferecê-la à deliberação do corpo legislativo; é necessário muito mais do que isto, é necessário (...) ter a aquiescência da maioria": ${ }^{352}$ além de serem derrotados na esfera parlamentar, os representantes do grupo luzia ainda recebiam um irônico ensinamento acerca do regime representativo daquele que se mostrara seu mais persistente adversário. A insatisfação da bancada pernambucana levava a patrulha conservadora a concluir satisfeita que sua tese sobre o projeto - apenas uma concessão à facção que se levantara em Minas e em São Paulo no ano de 1842 - estivera certa. Felizes com o rumo tomado pelas discussões, os adversários de Fernandes Torres aproveitavam o

\footnotetext{
${ }^{350}$ Anais da Câmara dos Deputados. 18 de agosto de 1846. p. 574.

${ }^{351}$ Anais da Câmara dos Deputados. 19 de agosto de 1846. p. 588.

${ }^{352}$ Ibidem. p. 590.
} 
momento para afirmar a superioridade de suas convicções sobre as dos reformistas. O piauiense Souza Ramos dizia que sustentaria sempre "as atribuições que a Lei de 03 de dezembro deu ao governo" pois somente por meio dela seria possível "fazer frente às paixões desregradas" que ainda existiam por todo o país. Somente aquela lei poderia "manter por toda a parte a ordem pública," tão ameaçada pelo anarquismo de algumas facções. ${ }^{353}$ A mensagem aos ex-rebeldes estava dada: derrotados militarmente em 1842 , também o haviam sido pelos meios regulares nos anos de 1845 e 1846 . Por meio da atividade deliberativa, a representação nacional consagrava a Reforma do Código de Processo Criminal de 1841 como o verdadeiro interesse nacional.

De acordo com o regimento, pela indefinição da discussão, o projeto de reforma judiciária teve de sair da ordem do dia. O final de 1846 se aproximava e apenas os dois primeiros dos 37 artigos da proposta de Fernandes Torres haviam sido discutidos. Todas as tentativas de facilitar o debate, fazendo-o por capítulos, haviam fracassado: o ministro da justiça e as bancadas mineira e paulista não conseguiam obter o apoio da maioria parlamentar. Nem as petições, que em 1845 inundaram a Câmara, foram capazes de convencer os deputados de que a reforma da Lei de 03 de dezembro era uma necessidade urgente para o país; pelo contrário, serviram como prova da parcialidade da proposta de reforma. Em 1847 Fernandes Torres deixaria o ministério e em 1848 o qüinqüênio liberal seria encerrado abruptamente pelo levante dos praieiros em Pernambuco.

Entre 1845 e 1846, o debate sobre a reforma judiciária polarizou a Câmara a partir de uma divisão provincial: o descontentamento das elites políticas de Minas e São Paulo levou os deputados luzias a lutarem pela revisão da Lei de 03 de dezembro de 1841; entretanto, a patrulha conservadora foi capaz de liderar a oposição aos projetos de reforma judiciária e, ao receber a adesão de importantes liberais do norte, pintaram a demanda dos paulistas e mineiros como um eco da rebeldia de 1842. Prevaleceu a opinião de D. Manoel, Paulino, Ferraz e França Leite: a falta de apoio à proposta de lei por parte da grande bancada praieira - que permaneceu em silêncio durante a maior parte do debate - veio provar que o grupo luzia não conseguira transfigurar seu projeto de reforma judiciária em um assunto concernente ao interesse nacional. Ao invés de serem tomadas como representativas das vozes da nação, as demandas de paulistas e mineiros foram interpretadas como vontade de uma facção local.

${ }^{353}$ Anais da Câmara dos Deputados. 22 de agosto de 1846. p. 629. 
Tanto os peticionários quanto os deputados luzias foram incapazes de se desvencilhar da pecha de rebeldia recebida em 1842: o declarado envolvimento de seus líderes parlamentares na revolta (como o caso do padre Marinho e de Álvares Machado) e a articulação da demanda por reforma pelas câmaras municipais e Assembléias Provinciais (centros do levante armado) trouxeram à tona a ligação entre os projetos e o movimento rebelde. Ao justificar a rebelião, a opinião de paulistas e mineiros se deslegitimava para o restante da representação nacional, que primava - naquela época de estabilização do regime - pela ordem e pela legalidade. Como disseram D. Manoel e outros oposicionistas, somente duas províncias - em flagrante ilegalidade - haviam se levantado contra as "leis reacionárias"; sendo assim, concluía a maioria dos legisladores, não cabia impor sua vontade sobre o restante da sociedade brasileira que as recebera bem.

Ainda que tentasse fugir das acusações, o grupo luzia continuava, entre 1845 e 1846, condenado pelos atos do passado recente e por um discurso que tendia ao radicalismo; discurso este que se encontrava, mesmo depois da pacificação, presente nas petições e em algumas falas parlamentares. Os luzias de dentro e de fora da Câmara foram incapazes de angariar aliados para sua causa pois não conseguiram se afastar dos ideais que conduziram o movimento rebelde. Como demonstrou a posição dos praieiros, para a maioria dos representantes da nação, os projetos de reforma judiciária apresentados (pelas comissões em 1845 e por Fernandes Torres em 1846) não diziam respeito às preocupações do país como um todo; mas eram expressão de uma vontade idiossincrática, restrita àqueles que quiseram impor uma concepção local de organização judiciária sobre toda a nação por meio de um conflito armado contra $o$ governo central.

Apesar da derrota dos projetos de 1845 e de 1846, um dado significativo deve ser aqui ressaltado: aqueles que em 1842 pegaram em armas contra as "leis reacionárias", pouco tempo depois se utilizaram de elementos legítimos do jogo político constitucional para defender idéias semelhantes. Seus representantes haviam chegado ao poder pelas vias legítimas e, assim, as elites políticas de Minas e São Paulo representadas por suas câmaras municipais e Assembléias Legislativas - buscaram defender seus ideais por meio das petições. Por mais que tenham saído derrotados, os ex-rebeldes demonstraram que passavam a aceitar o parlamento nacional como o espaço por excelência de negociação entre projetos divergentes; depunham as armas e se 
apegavam ao direito de petição. O dissenso dentro da ordem começava a ser aceito no Brasil; a lógica do regime representativo se impunha.

O duplo malogro do grupo luzia - no levante armado e na arena parlamentar significou mais do que a simples imposição unilateral de um projeto político conservador para o Império; ${ }^{354}$ significou que as diversas elites políticas brasileiras passavam por um processo de aprendizado no qual os grupos dissidentes deixavam paulatinamente de se comportar como facções para aderir às regras do regime. Mais do que o esmagamento de uma concepção de Estado, a derrota do grupo luzia significou a aceitação de uma forma de governo na qual a negociação parlamentar se impunha como modo de evitar a constante agitação armada. Derrotados no que dizia respeito à reforma judiciária, os liberais paulistas e mineiros continuaram - após 1846 - a defender suas idéias dentro da ordem.

\footnotetext{
${ }^{354}$ Sobre o tema da hegemonia saquarema no Segundo Reinado, consultar: Ilmar R. de Mattos. Op. Cit.
} 


\section{CONSIDERAÇÕES FINAIS}

A política do Segundo Reinado não foi determinada por um grupo homogêneo de estadistas ou por uma classe hegemônica que controlou o Estado. Como a discussão contida na presente dissertação buscou demonstrar, diversos setores da população brasileira se mobilizaram para exercer influência sobre os homens responsáveis por elaborar as instituições e as leis do Império. A heterogeneidade da composição dos grupos de peticionários é um dado importante a ser destacado ao final deste trabalho: no capítulo 3 os emissários das petições eram votantes, eleitores, párocos, juízes de paz e outras autoridades locais, habitantes de municípios maiores ou menores e de províncias variadas do Império, que não guardavam relações diretas entre si, a não ser terem sofrido com a violência e a fraude promovidas pelo Gabinete Maiorista; já no capítulo 4 prevaleceram representantes das praças comerciais mais ricas do início do Segundo Reinado, os quais, declaradamente, empreenderam um esforço conjugado para obter sua demanda; no capítulo 5 os peticionários, que também estavam conscientemente unidos por uma causa, eram basicamente membros das elites políticas locais de Minas Gerais e São Paulo que, no ano de 1842, haviam se envolvido num levante armado contra o poder central e sido derrotados.

Diferente da difundida imagem de uma sociedade inerte perante um Estado todopoderoso ou perante uma elite econômica capaz de instrumentalizar as instituições em benefício próprio, a análise documental empreendida nos capítulos precedentes mostrou que determinados grupos de cidadãos brasileiros foram capazes, durante a crucial década de 1840, de participar do debate dos mais variados assuntos políticos de seu tempo: as fraudes e violências eleitorais - tema dos mais polêmicos durante todo o período monárquico - ocuparam as petições de votantes e eleitores; uma nova legislação mercantil, ansiada desde os tempos da dominação portuguesa, foi demandada pelas associações comerciais das mais ricas cidades brasileiras; a questão judiciária, que durante a Regência causara um racha na elite política nacional, se constituiu no objeto das câmaras municipais paulistas e mineiras que se dirigiram à legislatura geral. Todos estes relevantes temas adentraram o debate parlamentar por intermédio da atividade peticionária.

As petições do início do Segundo Reinado obtiveram impacto sobre a Câmara dos Deputados pois se adequaram ao espírito do regime representativo da monarquia brasileira. Todos os grupos de petições partiram do diagnóstico de um problema que, 
mais do que simplesmente se referir a questões particulares, se articulava à existência do Império como um todo: as fraudes eleitorais, segundo as vítimas da "teoria dos cacetes", colocavam em cheque a legitimidade dos representantes da nação ao transformar o livre exercício do direito de voto numa luta entre facções inimigas; a falta de um corpo de leis comerciais no Brasil, de acordo com os principais negociantes da Corte, do Recife e de Salvador, afetava toda a economia do Império ao impedir o desenvolvimento mercantil do país; a Reforma do Código de Processo Criminal, acreditavam as elites políticas de Minas Gerais e São Paulo, tirava dos cidadãos brasileiros as mais sagradas garantidas outorgadas pela Constituição liberal de 1824. Conclui-se daí que os peticionários deixavam, na década de 1840, paulatinamente de se comportar como súditos à espera de justiça emanada das mãos de um soberano e passavam a utilizar seu direito constitucional com a finalidade de influenciar a construção de instituições e a elaboração de leis de relevância nacional.

Nenhum dos três grupos de petições se resumiu a apontar uma injustiça ou a requerer um privilégio restrito para si, eles demandavam algum tipo de ação dos representantes da nação que - acreditavam - teria como resultado o melhoramento da organização social e política do Império. A recorrência, em praticamente todas as petições, do tema da civilização evidencia que seus emissários compreendiam a lógica do processo de construção do Estado Nacional brasileiro. Diante das fraudes e violências eleitorais, os peticionários solicitaram medidas que impedissem a continuidade dos abusos e que garantissem a legítima representação da sociedade nacional no parlamento; quanto ao projeto do Código Comercial elaborado em 1834 por ilustres figuras ligadas ao comércio, pediu-se sua aprovação imediata como meio de se regularizar as relações mercantis no Brasil e, conseqüentemente, enriquecer o país; aqueles que se opunham à Lei de 03 de dezembro de 1841 requeriam sua modificação ou revogação, o que, supostamente, restabeleceria a justiça e a liberdade no Império.

Uma diferença fundamental que se pôde verificar comparando a trajetória dos três grupos de petições analisados nos capítulos 3, 4 e 5 foi o resultado obtido por cada um deles: as queixas acerca de abusos eleitorais foram indiretamente contempladas, pois a Câmara, ao levar em conta as denúncias, acabou por concluir que as "eleições do cacete" deslegitimavam a legislatura eleita no final de 1840 e, alguns anos depois, muitos dos parlamentares acusados de se beneficiarem das fraudes e violências tomaram para si a missão de sanar o mal que corrompia a representação nacional; a causa das associações comerciais, depois de ser insistentemente colocada diante dos deputados 
gerais e de ser abraçada por aliados dos negociantes de grosso trato dentro da Câmara, foi diretamente contemplada por meio da aprovação sem alterações significativas do projeto idealizado em 1834; já o clamor por reformas das elites políticas paulista e mineira, apesar de ter gerado propostas de lei e importantes debates acerca da organização judiciária brasileira, não resultou na revisão da Lei de 03 de dezembro por estar diretamente relacionado com o levante armado de 1842.

Ainda que nem todos os peticionários tenham sido bem-sucedidos quanto à obtenção de suas demandas, suas propostas foram levadas em consideração pelos representantes da nação e, direta ou indiretamente, influenciaram a definição do interesse nacional. Diante das demandas apresentadas à Câmara por intermédio da atividade peticionária, os deputados não ficaram inertes. $\mathrm{O}$ regime monárquico brasileiro, durante a década de 1840, mostrou-se responsivo aos apelos da sociedade: assim como em outros países onde a representação política se estabeleceu, no Império o diálogo entre governantes e governados foi fundamental para o processo legislativo. Este diálogo deu as diretrizes para as ações dos legisladores quando importantes assuntos políticos foram debatidos. As demandas contidas nas petições não determinaram as decisões dos parlamentares, contudo esclareceram-lhes acerca das expectativas dos cidadãos brasileiros. Constituiu-se no Brasil imperial uma relação típica de representação já que a definição da vontade geral, ainda que conduzida por um grupo de notáveis, se pautou sobre um complexo debate público que transcendia os palácios da Corte.

O regime representativo foi moldado para superar, na esfera política nacional, um governo cujas ações se voltassem para a resolução de questões pontuais. A concepção, cara ao Antigo Regime, de que ao soberano cabia apenas distribuir justiça já era obsoleta na década de 1840. Acreditava-se, desde fins do século XVIII em alguns países ocidentais, que a resolução de problemas particulares cabia a outra instância que não o Poder Legislativo. Um novo tipo de governo havia sido forjado com a finalidade de barrar a ação de facções que, voltadas para fins idiossincráticos, pudessem colocar em risco os laços da comunidade política. A consolidação do Estado Nacional impunha que as leis e as instituições unificassem as complexas sociedades modernas as quais, por si mesmas, já possuíam muitas diferenças internas. Tais diferenças encontravam no parlamento um local para negociação regulada. O ato legislativo, conduzido pelos notáveis representantes da nação, consistia em amalgamar as diferenças presentes no seio da nação, transformando-as em algo que pudesse ser definido como interesse 
nacional e que, conseqüentemente, fosse considerado legítimo pelos mais importantes grupos da sociedade.

As ações tanto de peticionários quanto de deputados no início do Segundo Reinado estiveram em sintonia com a teoria política do regime representativo. Ao estudar a atividade peticionária e sua repercussão no debate parlamentar da década de 1840 no Brasil, foi possível compreender que o sucesso ou o insucesso de um projeto político dependia de sua capacidade de convencer a maioria da representação nacional de que, de fato, sua adoção contribuiria para a felicidade geral. A pecha de facciosismo era a mais grave que se podia impingir a um interesse; de modo inverso, todos, peticionários e deputados, buscavam convencer aos demais agentes políticos que obravam apenas pela paz, pela civilização e pelo engrandecimento do Império. Estavam governantes e governados agindo de acordo com a lógica do sistema que regia a monarquia constitucional. 


\section{FONTES}

Anais da Câmara dos Deputados. Disponíveis no endereço eletrônico: http://imagem.camara.gov.br/pesquisa diario basica.asp. Acessado nos anos de $2008 \mathrm{e}$ 2009.

Bill of Rights. Disponível no endereço eletrônico:

http://www.archives.gov/exhibits/charters/ bill_of_rights.html. Acessado em 13 de janeiro de 2010.

BLAKE, Augusto Victorino Alves Sacramento. Diccionario Bibliographico Brazileiro. Terceiro e quarto volumes. Nendeln: Kraus Reprint, 1969.

BURKE, Edmund. The Select Works of Edmund Burke. Volume 4: Miscellaneous Writings. Indianapolis: Liberty Fund, 1999.

University Press, 2001.

Reflection on the Revolution in France. Stanford: Stanford

Constituição Política do Império do Brasil de 25 de março de 1824. Disponível no endereço eletrônico:

http://www.planalto.gov.br/ccivil_03/constituicao/constituiçao24.htm. Acessado em 08 de setembro de 2009.

Constitution de 1791. Disponível no endereço eletrônico:

http://mjp.univ-perp.fr/france/co1791.htm. Acessado em 26 de agosto de 2009.

HAMILTON, Alexander, JAY, John e MADISON, James. The Federalist. Nova York: Barnes and Nobles, 2006.

MACEDO, Joaquim Manuel de. Anno Biographico Brazileiro. Primeiro e segundo volumes. Rio de Janeiro: Typographia e Litographia do Imperial Instituto Artistico, 1876.

Suplemento do Anno Biographico Brazileiro. Rio de

Janeiro: Typographia Perseverança, 1880.

MARINHO, José Antonio. História da Revolução de 1842. Brasília: Senado Federal, 1978.

MILL, John Stuart. Essays on Politics and Society. Considerations on Representative Government. Toronto/Buffalo: University of Toronto Press, 1977.

PAINE, Thomas. Common Sense and Other Writings. Nova York: Barnes and Nobles, 2005.

Petições enviadas à Câmara dos Deputados entre 1840 e 1853. Centro de Documentação e Informação. Arquivo da Câmara dos Deputados. Brasília. Consultado em fevereiro de 2009. 
Revista do Instituto Archeologico e Geographico Pernambucano. Quarto ano, tomo segundo, número 13. Recife: outubro de 1866.

SIEYÈS, Emmanel-Joseph. Vues sur les moyens d'execution dont les représentans de la France pourront disponer en 1789. pp. 19-20. Disponível no endereço eletrônico:

http://gallica.bnf.fr/ark:/12148/ bpt6k41688x.image.r=sieyès.f5.langPT. Acessado em 01 de junho de 2009.

SISSON, Sébastien Auguste. Galeria dos Brasileiros Ilustres. Volume I. Brasília: Senado Federal, 1999. 


\section{BIBLIOGRAFIA}

ANNINO, Antonio (coord.). Historia de las Elecciones en Ibero América, Siglo XIX. De la formación del espacio político nacional. México: Fondo de Cultura Económica, 1995.

BADDINI, Cássia Maria. Sorocaba no Império: comércio de animais $e$ desenvolvimento urbano. São Paulo: Annablume, 2002.

BELlOTO, Heloísa L. (coord.). Nova História da Expansão Portuguesa. Volume 8: $O$ Império Luso-Brasileiro. 1750-1822. Lisboa: Estampa, 1986.

BENTIVOGLIO, Julio Cesar. "O Império das Circunstâncias: o Código Comercial e a política econômica brasileira (1840-1860)". Tese de doutorado defendida no ano de 2002 na Universidade de São Paulo.

BICALHO, Maria Fernanda. A Cidade e o Império: o Rio de Janeiro no século XVIII. Rio de Janeiro: Civilização Brasileira, 2003.

BOXER, Charles R. Portuguese Society in the Tropics: the municipal councils of Goa, Macao, Bahia, and Luanda, 1510-1800. Madison/Milwaukee: University of Wisconsin Press, 1965.

CARDIM, Pedro. Cortes e Cultura Politica no Portugal do Antigo Regime. Lisboa: Cosmos, 1998.

CARVALHO, José Murilo de. A Construção da Ordem: a elite política imperial/Teatro das Sombras: a política imperial. Rio de Janeiro: Civilização Brasileira, 2007.

CARVALHO, Marcus Joaquim M. de e CÂMARA, Bruno Augusto D. "A Insurreição Praieira”. Almanack Brasiliense (IEB/USP). Número 8, novembro de 2008. Disponível no endereço eletrônico: http://www.almanack.usp.br/PDFS/8/08_Forum 01.pdf. Acessado no dia 07 de fevereiro de 2010.

CONRAD, Robert E. Os Últimos Anos da Escravatura no Brasil. Rio de Janeiro: Civilização Brasileira, 1978.

DANTAS, Monica Duarte. "O Código do Processo Criminal e a Reforma de 1841: dois modelos de organização do Estado (e suas instâncias de negociação)". Conferência apresentada junto ao IV Congresso do Instituto Brasileiro de História do Direito Autonomia do direito: configurações do jurídico entre a política e a sociedade. São Paulo: 2009.

DAVIS, David Brion. Slavery and Human Progress. Nova York/Oxford: Oxford University Press, 1986.

DOLHNIKOFF, Miriam. O Pacto Imperial: origens do federalismo no Brasil. São Paulo: Globo, 2005. 
"Império e governo representativo: uma releitura". Cadernos do CRH (UFBA). Volume 21, 2008. Disponível no endereço eletrônico: http://www.cadernocrh.ufba.br/viewarticle.php?id=543. Acessado em 15 de novembro de 2008.

. "Representação na monarquia brasileira". Almanack Brasiliense (IEB/USP). Número 9, maio de 2009. Disponível no endereço eletrônico: http://www.almanack.usp.br/neste numero/n01/index.asp? edicao=9\&tipo=forum\&cont eudo $=290$. Acessado em 05 de maio de 2009.

DRESCHER, Seymour (org.). From Slavery to Freedom: comparative studies in the rise and fall of atlantic slavery. Nova York: New York University Press, 1999.

. "Public opinion and parliament in the abolition of the British slave trade". Parliamentary History. Volume 26, suplemento. 2007.

FERES JÚNIOR, João (org.). Léxico da História dos Conceitos Políticos do Brasil. Belo Horizonte: UFMG, 2009.

FONER, Eric. Free Soil, Free Labor, Free Men. The ideology of the Republican Party before the Civil War. Nova York/Oxford: Oxford University Press, 1995.

FREITAS, Marcos Cezar de (org.). Historiografia Brasileira em Perspectiva. São Paulo: Contexto, 2005.

GRAHAM, Richard. Clientelismo e Política no Brasil do Século XIX. Rio de Janeiro: UFRJ, 1997.

GREGÓRIO, Vítor Marcos. "Uma Face de Jano: a navegação do rio Amazonas e a formação do Estado brasileiro (1838-1867)". Dissertação de mestrado defendida no ano de 2008 na Universidade de São Paulo.

"A criação da província do Paraná: uma agenda de pesquisa". Conferência apresentada junto ao IV Congresso Internacional de História. Maringá: 2009. Disponível no endereço eletrônico:

http://www.pph.uem.br/cih/anais/trabalhos/172.pdf. Acessado em 09 de dezembro de 2009.

HESPANHA, Antonio Manuel. As Vésperas do Leviathan. Instituições e poder politico, Portugal-séc. XVII. Coimbra: Almedina, 1994.

(coord.). História de Portugal. Volume 4: O Antigo Regime (1620-1807). Lisboa: Estampa, 1998.

HOBSBAWM, Eric. Industry and Empire. The birth of the Industrial Revolution. Nova York: The New Press, 1999.

HOLANDA, Sérgio Buarque de (org.). História Geral da Civilização Brasileira. Tomo II: O Brasil Monárquico. Volume 3: O processo de emancipação. Rio de Janeiro: Bertrand Brasil, 2003. 
(org.). História Geral da Civilização Brasileira. Tomo II: O Brasil Monárquico. Volume 4: Dispersão e unidade. Rio de Janeiro: Bertrand Brasil, 2003.

HUNT, Lynn. Política, Cultura e Classe na Revolução Francesa. São Paulo: Companhia das Letras, 2007.

LENHARO, Alcir. As Tropas da Moderação: o abastecimento da Corte na formação política do Brasil. 1808-1842. Rio de Janeiro: Biblioteca Carioca, 1993.

MANIN, Bernard. Principes du Gouvernement Représentatif. Paris: Flammarion, 1996.

MATTOS, Ilmar R. de. O Tempo Saquarema. São Paulo: Hucitec, 2004.

MORGAN, Edmund S. Inventing the People. The rise of popular sovereignty in England and America. Nova York: W. W. Norton \& Company, 1989.

MOTA, Carlos Guilherme (org.). 1822: Dimensões. São Paulo: Perspectiva, 1986.

NEEDELL, Jeffrey. The Party of Order: the conservatives, the State, and slavery in the Brazilian monarchy. 1831-1871. Stanford: Stanford University Press, 2006.

NUNES, Tassia T. "Liberdade de imprensa no Império brasileiro. Os debates parlamentares (1820-1840)". Dissertação de mestrado defendida no ano de 2010 na Universidade de São Paulo.

PITKIN, Hannah F. The Concept of Representation. Berkeley/Los Angeles/Londres: University of California Press, 1997.

PORTO, Walter C. O Voto no Brasil. Da Colônia à $6^{a}$ República. Rio de Janeiro: Topbooks, 2002.

PRZEWORSKI, Adam. "Consensus and Conflict in Western thought on representative government". Conferência apresentada junto ao Beijing Forum. Beijing: 2006. Disponível no endereço eletrônico:

http://politics.as.nyu.edu/docs/IO/2800/beijing-ba.pdf. Acessado em 13 de dezembro de 2009.

RIBEIRO, Gladys Sabina. (org.). Brasileiros e Cidadãos: modernidade política, 18221930. São Paulo: Alameda, 2008.

RIDINGS, Eugene. Business Interest Groups in Nineteenth-Century Brazil. Cambridge: Cambridge University Press, 1994.

RODRIGUES, Jaime. "Liberdade, humanidade e propriedade: os escravos e a Assembléia Constituinte de 1823". Revista do Instituto de Estudos Brasileiros. Número 39, 1995. Disponível no endereço eletrônico:

http://www.ieb.usp.br/revista/revista039/rev039jaimerodrigues.pdf. Acessado em 02 de maio 2008. 
ROSANVALLON, Pierre. L'État en France: de 1789 à nos jours. Paris : Éditions du Seuil, 1992.

SABA, Roberto Nicolas P. F. “A Questão Servil no Debate Parlamentar (1883-1884)". Relatório de pesquisa FAPESP (1). Maio de 2007.

. “A Questão Servil no Debate Parlamentar (1885)". Relatório de pesquisa FAPESP (2). Novembro de 2007.

"O Libelo do Povo: um incêndio em terras saquaremas". Revista Em Tempo de Histórias (UnB). Volume 14, 2009. Disponível no endereço eletrônico:

http://vsites.unb.br/ih/novo portal/portal his/revista/arquivos/edicoes anteriores/1.2009 N2\%20O\%20Libelo\%20do\%20Povo\%20-\%20Roberto\%20Saba.pdf. Acessado em 20 de setembro de 2009 .

SÁEZ, Hernan Enrique L. "Nas asas de Dédalo. Um estudo sobre o meio circulante no Brasil entre os anos de 1840 e 1853". Dissertação de mestrado defendida no ano de 2008 na Universidade de São Paulo.

SILVA, Wlamir. Liberais e Povo: a construção da hegemonia liberal-moderada na província de Minas Gerais (1830-1834). São Paulo: Hucitec, 2009.

TILLY, Charles. Popular Contention in Great Britain, 1758-1834. Cambridge/Londres: Harvard University Press, 1995.

VOSS, Lex Heerma van (ed.). Petitions in Social History. International Review of Social History. Volume 41, suplemento 9. Nova York: Cambridge University Press, 2001.

WOOD, Gordon S. The Radicalism of the American Revolution. Nova York: Vintage Books, 2003. 
